Golden Gate University School of Law GGU Law Digital Commons

1915

\title{
Geology and Oil Resources of the West Border of the San Joaquin Valley North of Coalinga, California
}

US Department of the Interior

Robert Anderson

Robert W. Pack

Follow this and additional works at: https://digitalcommons.law.ggu.edu/federal_documents

Part of the Oil, Gas, and Mineral Law Commons

\section{Recommended Citation}

US Department of the Interior; Anderson, Robert; and Pack, Robert W., "Geology and Oil Resources of the West Border of the San Joaquin Valley North of Coalinga, California" (1915). Federal Documents. 20.

https://digitalcommons.law.ggu.edu/federal_documents/20 
DEPARTMENT OF THE INTERIOR

UNITED STATES GEOLOGICAL SURVEY

GEORGE O'TIS SMI'IH, DIRECTOR

BULLETIN 603

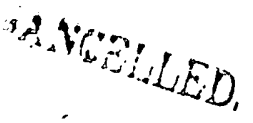

GEOLOGY AND OIL RESOURCES

OF THE

\section{WEST BORDER OF THE SAN JOAQUIN VALLEY NORTH OF COALINGA, CALIFORNIA}

BY 。

ROBER'T ANDERSON AND ROBERT W. PACK

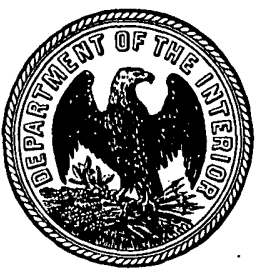

WASHIINGTON

GOVERNMENT PRINTING OFFIOE

1915 



\section{CONTENTS.}

Intoduge.

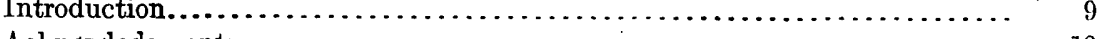

Acknowledgments. . .............................................. 13

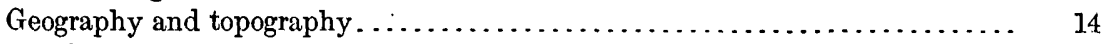

General geographic features................................ 14

Conditions limiting the accuracy of the map..................... 16

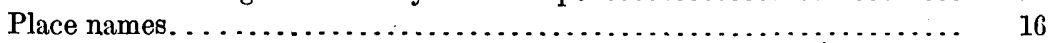

General topographic features.................................... 21

Climate, drainage, and vegetation. . . . . . . . . . . .

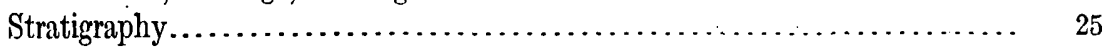

General statement. . . . . . . . . . .

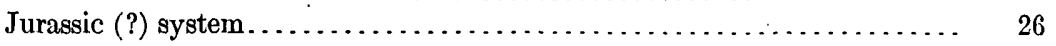

Franciscan formation........................................ 26

General features..................................... 26

Economic importance................................ $\quad 31$

General character of post-Franciscan rocks................... 31

Principal features. . . . . . . . . . . . . 31

Formations in the southern area......................... 33

Formations in the northern area........................... 34

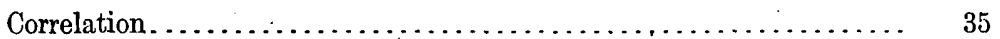

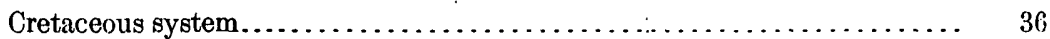

Chico group (Upper Cretaceous) . . . . . . . . . . . . . . . . . . 30

General character.................................. 36

Panoche formation................................. 39

General features.................................... 39

Area south of Panoche Creek....................... $\quad 40$

Area north of Panoche Creek........................ 42

Relation to petroleum........................... 45

Moreno formation.................................... 46

Definition.................................... 46

Previous correlation............................... 49

Lithology and local development................... 51

Area south of Pacheco Pass........................ 51

Area north of Pacheco Pass....................... 54

Lower shale............................... 55

Upper sandstone......................... 56

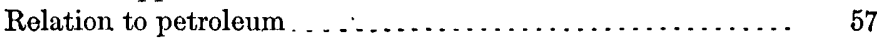

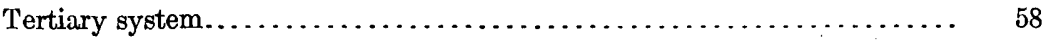

Eocene series........................................ 58

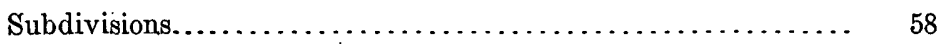

Martinez (?) formation. . . . . . . . . . . . .

General features................................... 58

Area south of Panoche Creek........................ $\quad 59$

Distribution and correlation...................... $\quad 59$

Cantua sandstone member...................... 61

Clay shale................................. 62 
Stratigraphy-Continued.

Tertiary system-Continued.

Eocene series-Continued.

Martinez (?) formation-Continued. Page.

Area north of Panoche Creek. ..................... $\quad 63$

Stratigraphic relations........................... 64

Evidence of age.................................. $\quad 66$

Tejon formation.................................... $\quad 67$

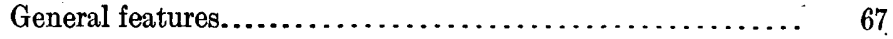

Stratigraphic relations........................... $\quad 67$

Distribution and lithology ......................... $\quad 69$

Areas south of Panoche Creek.................... $\quad 69$

Areas in the Panoche Hills........................ $\quad 70$

Area between Little Panoche and Ortigalito creeks...... 71

Area between Quinto and Hospital creeks. .......... 71

Area near Tesla............................. $\quad 72$

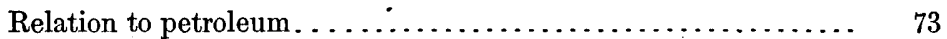

Oligocene (?) series.................................. 74

Kreyenhagen shale............................... $\quad 74$

General features................................ 74

Lithology ...................................... $\quad 75$

Stratigraphic relations........................... $\quad 75$

Previous description and correlation. . . . . . . . . . . . $\quad 76$

Distribution and thickness....................... $\quad 77$

Relation to petroleum.......................... 78

Miocene and Pliocene series............................. $\quad 78$

Subdivisions........................................ $\quad 78$

Relation to petroleum........................... $\quad 79$

Monterey group................................... $\quad 80$

Vaqueros formation (lower Miocene) ................. $\quad 80$

General features and stratigraphic relations............ 80

Area along the San Joaquin Valley................ 82

Lower member......................... 82

Big Blue serpentinous member............... 83

Area in The Vallecitos........................ 84

Area near Llanada. .............................. 86

Relation to petroleum........................ 87

Undifferentiated Miocene.............................. $\quad 88$

Area near Tesla................................. $\quad 88$

Area between Garzas and Crow creeks................ $\quad 89$

Area near Llanada. ............................... $\quad 90$

Relation to petroleum............................ $\quad 90$

Santa Margarita (?) formation (middle Miocene) ............. $\quad 91$

Areal extent and stratigraphic relations................ 91

Lithology and thickness.......................... $\quad 93$

Relation to petroleum............................ $\quad 93$

Jacalitos and Etchegoin formations (upper Miocene and Pliocene?). $\quad 94$

Distribution and stratigraphic relations............... 94

Lithology and thickness......................... 95

Relation to petroleum........................... 96

San Pablo formation (upper Miocene) $\ldots \ldots \ldots \ldots \ldots \ldots \ldots \ldots \ldots . \quad 96$

General character............................. 96

Distribution................................ $\quad 97$ 
Stratigraphy-Continued.

Tertiary system-Continued.

Miocene and Pliocene series-Continued.

San Pablo formation (upper Miocene)-Continued. Page.

Stratigraphic relations........................... $\quad 97$

Lithology and thickness.......................... 98

Relation to petroleum........................... 101

Tulare (?) formation (Pliocene and Pleistocene?) ........... 101

Ștratigraphic relations.......................... 101

Distribution, lithology, and thickness................ 102

Relation to petroleum........................ $\quad 105$

Quaternary system........................................ 105

Terrace deposits and alluvium............................ 105

Igneous rocks............................................. 106

Structure............................................... 108

General features............................................... 108

Structural details......................................... 110

Coalinga anticline and syncline......................... $\quad 110$

Ciervo anticline................................... 111

Vallecitos syncline.................................... 111

Structure in Panoche Hills and Panoche Valley................. 112

Structure near Salado Creek.............................. 113

Structure between Hospital Creek and Livermore Pass........... 113

Los Banos fold........................................ 114

Faults................................................ 114

Petroleum..................................................... 116

Factors influencing accumulation of the oil..................... 116

Evidences of oil............................................ 122

The oil-bearing formations............................... 122

Moreno formation (Upper Cretaceous) $\ldots \ldots \ldots \ldots \ldots \ldots \ldots \ldots \ldots \ldots, 122$

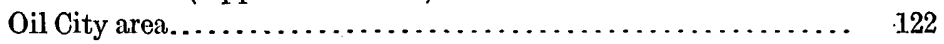

Mancillas Canyon.................................. 123

North of The Vallecitos............................. 123

North of The Pimental.............................. 125

Ciervo anticline..................................... 125

Other localities............................................ 126

Martinez (?) formation (lower Eocene) $\ldots \ldots \ldots \ldots \ldots \ldots \ldots \ldots \ldots \ldots . \quad 127$

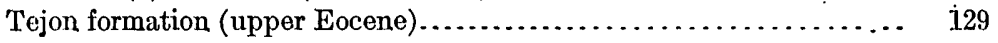

Kreyenhagen shale (Oligocene?)........................ 130

Vaqueros formation (lower Miocene) $\ldots \ldots \ldots \ldots \ldots \ldots \ldots \ldots \ldots \ldots \ldots$

Later Miocene beds..................................... 135

The Vallecitos.................................... 135

Tẻsla region ...................................... 136

Oçcurrence of oil in different areas and future possibilities............ 137

Scope of discussion.................................... 137

Eastside or Coalinga anticline field........................ 139

Structure and occurrence of oil....................... 139

General features.................................. 139

Moreno formation.............................. 140

Martinez (?) and Tejon formations ................... 141

Vaqueros formation............................. 145

Kreyenhagen shale................................ 146

Post-Vaqueros formations......................... 147

Limits of the field................................ $\quad \mathbf{1 4 8}$ 
Petroleum-Continued.

Occurrence of oil in different areas and future possibilities-Continued. Page.

Westside or Coalinga syncline field....................... 153

Reason for discussion................................ 153

Structure and occurrence of oil....................... 153

Possible deep sands................................ 156

Conclusion...................................... 161

Outer foothills and valley border from the north edge of the Coalinga

field to Tumey Gulch............................... 162

Inner foothills from the Coalinga district to New Idria and beyond... 165

Vallecitos district.................................... 167

General features................................. 167

South flank of the Vallecitos syncline..................... 169

North flank and east end of the Vallecitos syncline........... 171

General features.................................. 171

West half of north flank of The Vallecitos............... 172

East half of north flank of The Vallecitos.............. 1.74

Conclusions regarding the Vallecitos district................ 177

Crest and flanks of the Ciervo anticline.................... 178

Region around the mouth of Panoche Creek................. 181

Region from Panoche Creek to Corral Hollow................... 182

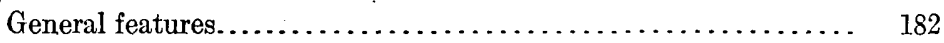

Panoche Hills and Panoche Valley...................... 183

Area about Salado Creek................................. 184

Conclusion........................................ 185

Tesla area............................................... 186

Principal features......................................... 186

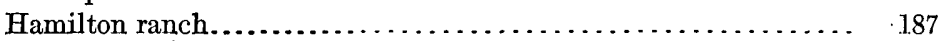

Altamont anticline and outlying areas.................. 191

Conclusions regarding the Tesla district.................. 192

Origin of the oil............................................ 194

General discussion and conclusions......................... 194

Supplementary statements relating to the origin of oil in the Diablo

Range ............................................ 199

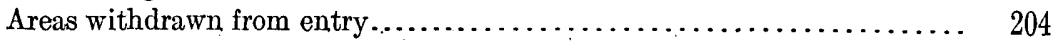

Mineral deposits other than petroleum.......................... 206

Quicksilver........................................... 206

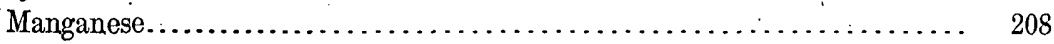

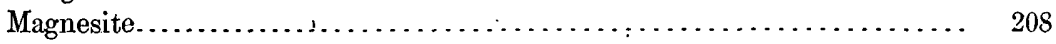

Chromite.............................................. 208

Benitoite............................................. 208

Coal................................................ 209

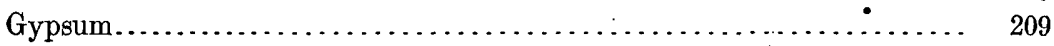

Lime.............................................. 210

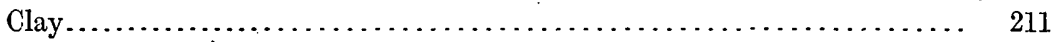

Diatomaceous earth.......................................... 211

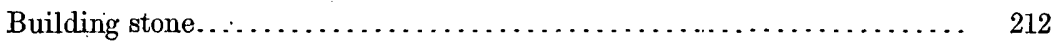

Gravel................................................. 212

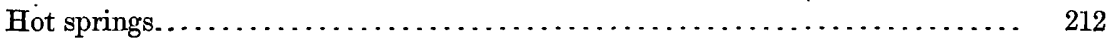

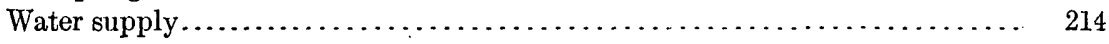

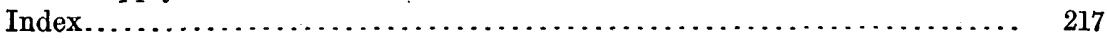




\section{ILLUSTRATIONS.}

Prate I. Geologic map of the western border of San Joaquin Valley, Cal., be-

Page. tween the Coalinga oil field and Livermore Pass, with geologic sections.................................. In pocket

II. Hills formed by northeastward-dipping Cretaceous and Tertiary strata north of the Coalinga district........................

III. Correlation of the principal sections in the east flank of the Diablo

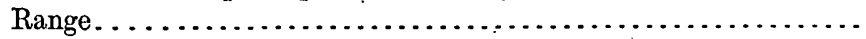

IV. $A$, Joaquin Rocks, formed by massive sandstone of the Panoche formation; $B$, Characteristic outcrops of conglomerate in the Panoche formation north of Panoche Pass. .......................

- V. Sandstone dikes in the Moreno formation in the Panoche Hills......

VI. West end of Griswold Hills, formed by southward-dipping Cretaceous

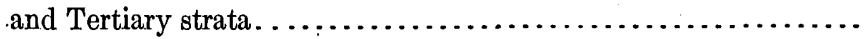

VII. Typical cliffs of white quartzose sandstone of the Tejon formation, in the Cantua region. . . . . . . . . . . . . . . . . . . . . . . . . . . . .

VIII. $A$, Typical exposure of the siliceous Kreyenhagen shale on Domengine Creek, showing characteristic surface crumpling; $B$, Sand-. stone dikes in the Kreyenhagen shale......................

IX. $A$, Unconformity of the oil sands of the Vaqueros formation on oily Kreyenhagen shale along Silver Creek; $B$, Unconformity of sandstone of the Vaqueros formation on Kreyenhagen shale along the east face of the Ciervo Hills..............................

$\mathrm{X}$. Low-dipping beds of the Kreyenhagen shale and Vaqueros formation near the south end of the Ciervo anticline....................

XI. $A$, Characteristic outcrop of the Big Blue serpentinous member of the Vaqueros formation near Cantua Creek; $B$, Huge serpentine bowlders in the Big Blue member on Martinez Creek...............

XII. A, Terrace deposits of the Tulare (?) formation at the crest of the Panoche Hills; $B$, Terrace deposits in Little Panoche Valley....

XIII. $A$, Cavernous-weathering concretionary sandstone of the Panoche formation on El Puerto Creek; $B$, Terrace gravels and sands resting on shale of the Moreno formation on Ortigalito Creek.........

XIV. Geologic map of part of the Tesla quadrangle..................

Figure 1. Index map of a part of California. . . . . . . . . . . . . . . . . . . .

2. Generalized columnar section of the rocks in the Diablo Range, in the southern part of the region between Coalinga and Livermore Pass.

3. Generalized columnar section of the rocks in the Diablo Range, in the northern part of the region between Coalinga and Livermore Pass. .

4. Frypothetical section through the Westside field, in the Coalinga district........................................

5. Hypothetical section through the Hamilton ranch, near Tesla.... 



\title{
GEOLOGY AND OIL RESOURCES OF THE WEST BORDER OF THE SAN JOAQUIN VALLEY NORTH OF COALINGA, CALIFORNIA.
}

\author{
By Robert Anderson and Robert W. Pack.
}

\section{INTRODUCTION.}

The main purpose of this report is to present the geologic evidences of the existence of petroleum in the rocks along the foothills that form the western border of the San Joaquin Valley, Cal., between the Coalinga oil district and Livermore Pass and to discuss the chances of finding oil in commercial quantity in this region. With this end in view a general description of the physical features of the region is given, with special reference to the geologic features which have a bearing on the presence or absence of petroleum and which have determined the conclusions reached regarding. the presence or absence of oil in the several areas considered. The writers take this opportunity of presenting also some additional geologic information, which may be of interest to the geologist if not to the oil prospector.

The information here presented was obtained chiefly through field studies carried on by the writers during parts of 1909, 1910, and 1911 . The work in the region north of Panoche Valley was done mainly by the junior author, who spent part of the summer and fall of 1910 mapping the geology of that region with the assistance of Mr. Eugene L. Ickes, and about 10 days in the summer of 1911 with the assistance of Mr. Alvin T. Schwennesen. The region here discussed lies along the east flank of the Diablo Range and the adjacent edge of the San Joaquin plain between latitudes $36^{\circ} 15^{\prime}$ and $37^{\circ} 45^{\prime} \mathrm{N}$., or between Tps. $19 \mathrm{~S}$. and $2 \mathrm{~S}$. Mount Diablo base. The area mapped is about 130 miles long and on the average about 12 miles wide, including about 1,500 square miles and covering parts of the western edge of Fresno, Merced, Stanislaus, and San Joaquin counties and of the eastern edge of San Benito and Alameda counties. The location of this area and of the districts in the southern half of California where oil occurs is shown in the index map (fig. 1).

This region is the topographic continuation of the belt occupied by the Coalinga oil field, on the south, and the Temblor Range fields, still farther south, and is similar to those fields in its geographic position and its main geologic features. The developed oil fields to the 
south are on the border of San Joaquin Valley, along the easternmost foothills of the Coast Ranges. The position of these fields is due to the presence there of moderately folded Tertiary beds, the sources and present reservoirs of the oil, and by analogy it is therefore reasonable to suppose that if petroleum is present north of. Coalinga it is most

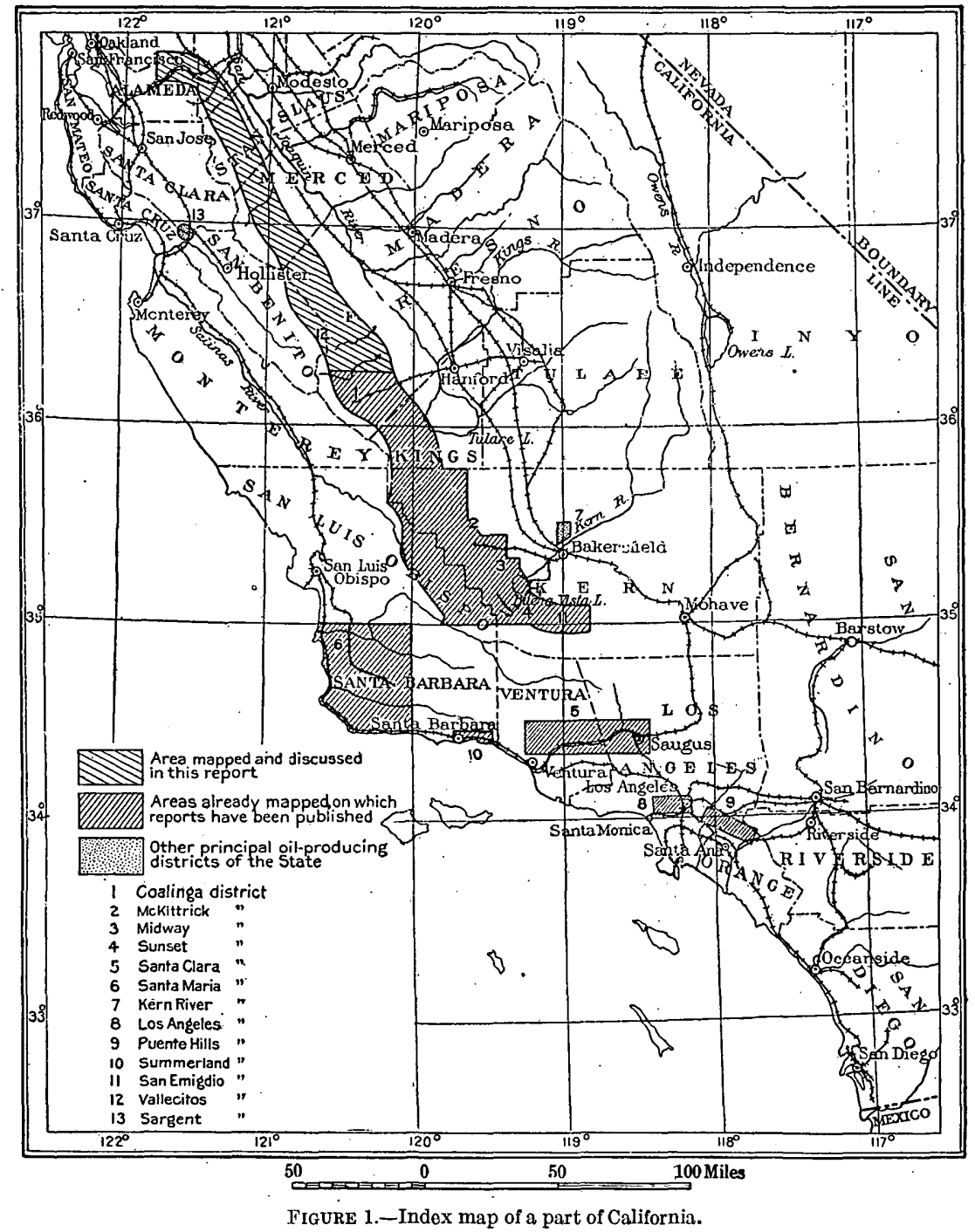

likely to occur in the foothills or along the border of the valley. The topographic and geologic similarity of the foothill belt here considered to the belt containing the productive fields farther south made the existence of oil fields in this region seem probable, and it was chiefly with a view to determining whether or not such fields did exist that field work leading to the present report was undertaken. 
Few adequate tests by boring have been made in this region and very little information is available concerning the possibility that its rocks may contain oil. In so far as finding new oil fields is concerned the examination proved disappointing. In certain small areas, however, in which evidences of oil are found the structure of the rocks is such as to make possible the accumulation of oil in moderate quantity. The work proved to be valuable in giving a basis for outlining areas to which prospecting for oil may reasonably be confined and in making certain that most of the region offers no promise of oil. The places in which some oil is likely to be found are $(a)$ small areas around The Vallecitos, $(b)$ a part of the region between Ciervo Mountain and Panoche Creek, and $(c)$ a very small area north of Tesla. A number of test wells indicate that the northern limit of the Coalinga field had practically been reached as early as 1908, within the Coalinga district, an indication that is confirmed by the details of the geology in the area just north of the area previously mapped. Furthermore, a detailed examination of the geologic features in most of the area from this locality northward to Livermore Valley showed that there is little reason to suppose that oil will be discovered in that area. The field studies resulted in the restoration to all forms of entry of large areas which had been withdrawn by the President of the United States on the recommendation of the Department of the Interior as possible oil lands pending investigation. Certain relatively small areas that may contain oil lands were not included in the restoration.

Besides determining the oil-bearing or non oil-bearing character of the several parts of the region, the study threw some light on the questions of the origin of the oil and the causes of its accumulation along certain parts of the border of the San Joaquin Valley and its absence in other places which at first sight would seem to offer conditions equally favorable. The evidence bearing on the origin of the oil strongly supports the belief that it was derived from minute organisms, such as diatoms and foraminifers, which occur abundantly in the shales with which the oil is associated. A very interesting result was the discovery that the lower oil-bearing shale of the Coalinga and Vallecitos districts and probably also the Tesla district is of Cretaceous age and organic origin.

The results of the study emphasize the importance of two conditions in determining points of accumulation of oil in the San Joaquin Valley fields-(a) the presence of a considerable quantity of shale of organic origin and $(b)$ the existence of anticlines and synclines running out toward the valley and producing pockets that collect and hold the oil. The first condition is well satisfied through the region under discussion, which contains thick formations of shale of organic origin. The second condition is not so well fulfilled. The scarcity of oil in this northern region is thought to be due not to the lack of an 
original supply but mainly to the regularity of the structure on the flank of the range north of the Coalinga district and the scarcity of spur folds such as characterize the valley border farther south, the structure having allowed the oil to escape.

The present report is one of the series of papers on the California oil fields published by the United States Geological Survey. The investigations of these fields was begun by George H. Eldridge in 1901, after he had examined the asphalt deposits of the State. After his death in 1905 the work was put in charge of Ralph Arnold, who made examinations of all the fields then developed along the coast and along the west side of the San Joaquin Valley, with the assistance of Robert Anderson and H. R. Johnson. Since Mr. Arnold's resignation from the Survey, in the spring of 1909 , special attention has been given to the examination of outlying districts to determine possible extensions of known oil fields or the existence of others. These investigations have been made under the general supervision of Mr. M. R. Campbell, of the United States Geological Survey, to whom the writers are greatly indebted for assistance and advice. The reports issued up to the present time are listed below.

Eldridge, G. H., The asphalt and bituminous rock deposits of the United States: U. S. Geol. Survey Twenty-second Ann. Rept., pt. 1, pp. 209-452, 1901.

Eldridge, G. H., The petroleum fields of California: U. S. Geol. Survey Bull. 213, pp. 306-321, 1903.

Eldridge, G. H., and Arnold, Ralph, The Santa Clara Valley, Puente Hills, and Los Angeles oil districts, southern California: U. S. Geol. Survey Bull. 309, 1907.

Arnold, Ralph, and Anderson, Robert, Preliminary report on the Santa Maria oil district, Santa Barbara County, Cal.: U. S. Geol. Survey Bull: 317, 1907.

Arnold, Ralph, Geology and oil resources of the Summerland district, Santa Barbara County, Cal.: U. S. Geol. Survey Bull. 321, 1907.

Arnold, Ralph, and Anderson, Robert, Geology and oil resources of the Santa Maria oil district, Santa Barbara County, Cal.: U. S. Geol. Survey Bull. 322, 1907.

Arnold, Ralph, The Miner ranch oil field, Contra Costa County, Cal.: U. S. Geol. Survey Bull. 340, pp. 339-342, 1908.

Arnold, Ralph, and Anderson, Robert, Preliminary report on the Coalinga oil district, Fresno and Kings counties, Cal.: U. S. Geol. Survey Bull. 357, 1908.

Arnold, Ralph, and Anderson, Robert, Geology and oil resources of the Coalinga district, Cal.: U. S. Geol. Survey Bull. 398, 1910.

Arnold, Ralph, and Johnson, H. R., Preliminary report on the McKittrick-Sunset oil region, Kern and San Luis Obispo counties, Cal.: U. S. Geol. Survey Bull. 406, 1910.

Anderson, Robert, Preliminary report on the geology and oil prospects of the CantuaPanoche region, California: U. S. Geol. Survey Bull. 431, pp. 59-87, 1911.

Anderson, Robert, Preliminary report on the geology and possible oil resources of the south end of the San Joaquin Valley, Cal.: U. S. Geol. Survey Bull. 471, pp. $106-136,1912$.

Pack, R. W., Reconnaissance of the Barstow-Kramer region, Cal.: U. S. Geol. Survey Bull. 541, pp. 141-154, 1914.

Pack, R. W., and English, W. A., Geology and oil prospects of Waltham, Priest, Bitterwater, and Peachtree valleys, central California: U. S. Geol. Survey 'Bull. 581, pp. 119-160, 1915. 


\section{ACKNOWLEDGMENTS.}

The writers wish to express their appreciation of the efficient assistance rendered by Mr. E. L. Ickes, who aided in the examination of the northern part of the region during the field season of 1910 . Many of the data noted here are taken from his observations. A like acknowledgment is due to Mr. A. T. Schwennesen, who assisted during the short field season of 1911. During the field season of 1909, Mr. Olaf Jenkins assisted in the conduct of the camp, in a region where various obstacles made the work at times trying.

To Mr. T. W. Stanton the writers are indebted for the examination of collections of fossil mollusks from over 100 localities in the Cretaceous beds; to Mr. F. H. Knowlton for the examination of fossil leaves obtained from various Tertiary formations; to Mr. J. C. Merriam, of the University of California, for the examination of the mammalian remains obtained from the Miocene beds; and to $\mathrm{Mr}$. D. T. Day for the chemical examination of certain samples of petroleum and specimens of oil-bearing rocks.

The writers wish to acknowledge also their indebtedness to previous workers in this general region and to those now engaged in its study, from all of whom valuable suggestions and interesting information have been obtained either through published writings or by word of mouth. Aside from the Survey reports already cited the principal published reports dealing with the geology of this region are arranged in chronologic order below:

Whitney, J. D., Meek, F. B., and Gabb, W. M., California Geol. Survey, Paleontology, vol. 1, 1864.

Whitney, J. D., California Geol. Survey, Geology, vol. 1, 1865.

Whitney, J. D., and Gabb, W. M., California Geol. Survey, Paleontology, vol. 2, 1869.

White, C. A., On the Mesozoic and Cenozoic paleontology of California: U. S. Geol. Survey Bull. 15, 1885.

Becker, G. F., Notes on the stratigraphy of California: U. S. Geol. Survey Bull. 19, 1885.

Becker, G. F., Geology of the quicksilver deposits of the Pacific slope: U. S. Geol. Survey Mon. 13, 1888.

Turner, H. W., and Stanton, T. W., Notes on the geology of the Coast Ranges of California: Am. Geologist, vol: 14, pp. 92-98, 1894.

Watts, W. L., The gas and petroleum yielding formations of the central valley of California: California State Min. Bureau Bull. 3, 1894.

Stanton, T. W., Faunal relations of the Eocene and Upper Cretaceous on the Pacific coast: U. S. Geol. Survey Seventeenth Ann. Rept., pt. 1, pp. 1011-1048, 1896.

Watts, W. L., Oil and gas yielding formations of California: California State Min. Bureau Bull. 19, 1900.

Anderson, F. M., $\Lambda$ stratigraphic study in the Mount Diablo Range of California: California Acad. Sci. Proc., 3d ser., Geology, vol. 2,No. 2, pp. 156-248, 1905.

Anderson, F. M., A further stratigraphic study in the Mount Diablo Range of California: Idem, 4th ser., vol. 3, pp. 1-40, 1908.

Dumble, E. T., Notes on Tertiary deposits near Coalinga oil field and their stratigraphic relations with Upper Cretaceous: Jour. Geology, vol. 20, No. 1, pp. 28-37, 1912. 
Only the papers by Watts deal with the occurrence of oil.

Of those to whom the writers are indebted for information through sources other than that of published writings, special acknowledgment is due to Messrs. Ralph Arnold and Harry R. Johnson, formerly of the United States Geological Survey; J. C. Merriam, of the University of California; J. P. Smith and J. R. Pemberton, of Stanford University; J. A. Taff and G. C. Gester, of the Southern Pacific Co., and F. M. Anderson, formerly with that company; W. R. Hamilton, formerly with the Associated Oil Co.; E. A. Starke, of the Standard Oil Co.; W. W. Orcutt, of the Union Oil Co.; B. M. Newcomb, manager, and J. G. Finch, superintendent, of the New Idria mines; W. S. Boggs and A. F. Roach, of the Imperial Oil Co.; W. H. Morgan, Daniel McDonald, and E. P. Plougher, of The Vallecitos; H. G. Heffron and Joseph Lemberger, of the Range 16 Oil Co.; F. W. Kemble, who drilled the Big Shell well near the Domengine ranch; R. H. McCreary, of the Cantua Oil Co.; J. Norrish, superintendent of the Mercy mine; and W. J. Rhodes; of the Tracy Oil Co.

As much of this region is sparsely settled and distant from sources of supplies, good water and the various necessities of life being frequently difficult to obtain, the traveler must trust largely to the hospitality of the inhabitants. .Without exception the courtesies extended to the writers during the course of their work were very hearty, and it is their desire here to express sincere appreciation of the welcome that was accorded and the assistance rendered them. It would be impossible to mention all who aided in this way, but the writers wish to express their gratitude particularly to Mr. and Mrs. S. C. Lillis and Miss Helen Lillis, who gave most generous assistance during the progress of the work; Mr. and Mrs. John Ashurst, of The Vallecitos; Mr. and Mrs. Thomas McDonald; and Messrs. Wm. Barnes, George Berg, W. S. Boggs, J. J. Castle, W. J. Hammonds, Thomas Hayes, Elmer House, Henry Mercy, J. J. Mercy, J. M. Quigley, A. F. Roach, Emil Sorensen, and George. Thoming.

\section{GEOGRAPHY AND TOPOGRAPHY.}

\section{GENERAL GEOGRAPHIC FEATURES.}

The region described in this report lies along the western edge of the San Joaquin Valley, in the western parts of San Joaquin, Stanislaus, Merced, and Fresno counties and the eastern parts of San Benito and Alameda counties, Cal. It covers a considerable part of the east flank of the Diablo Range, which is here the eastern-. most member of the Coast Ranges, and extends as a strip 8 to 20 miles wide from $36^{\circ} 15^{\prime}$ north latitude and $120^{\circ} 10^{\prime}$ west longitude northwestward about 130 miles to $37^{\circ} 45^{\prime}$ north latitude and $121^{\circ} 45^{\prime}$ 
west longitude. In the extreme south end the area examined extends from the valley to the crest of the Diablo Range, and in the north end from the valley's edge well up on the higher hills; but through most of the distance it includes only the foothills. The area geologically mapped (see Pls. I and XIV) is about 1,500 square miles.

Owing to its dryness this region is sparsely populated. The only village in the south end of the region is New Idria, which owes its existence to the quicksilver mines there. Panoche and Llanada, in the Panoche Valley, are merely stations and post offices on the stage line between New Idria and Tres Pinos. With the exception of tne Panoche Valley, the southern country is used only for grazing, and the ranches are far apart. The north end of the district is somewhat more settled. There are numerous ranches along the drainage courses through the hills, the land between the foothills and the railroad is mostly under cultivation, and several small towns are situated out in the valley along the railroad. Livermore Valley, the east end of which is shown on the map ( $\mathrm{Pl}$. XIV), is one of the most fertile valleys in central California and is dotted with fruit and grain ranches.

The north end of the region is readily accessible from places on the Southern Pacific and Western Pacific railroads, both of which are shown on the map. Altamont, a station common to both lines, is situated at the summit of Livermore Pass, between 50 and 60 miles by rail east of San Francisco, and marks the northern limit of the region examined. The north end of the region may be reached either from Altamont, from Livermore, or from Tesla and Carnegie, two small settlements on a branch line of the Western Pacific Railway, within the area mapped. As far south as Panoche Creek the district is readily accessible from numerous small towns between Tracy and Mendota, on the branch line of the Southern Pacific Co. that passes along the west side of the San Joaquin Valley at a distance of 3 to 15 miles from the foothills. South of Mendota no railroad follows the west side of the valley, but the foothills may be reached either from Mendota by the road to Panoche Creek and thence south by a road leading along the edge of the hills; or from Coalinga, located on a branch line of the Southern Pacific. The mountains in the south end of the area may be reached from Coalinga by a road that leads northwestward to the headwaters of Los Gatos Creek, whence branch roads lead to New Idria and other places within the region and to the Salinas Valley, on the west side of the Diablo Range. The district is also accessible from the west side of the range through Panoche Pass from the terminus of the Southern Pacific branch line at Tres Pinos, and through Pacheco Pass from Gilroy, on the main coast line of the Southern Pacific.

$812 \$ 1^{\circ}-$ Bull. $603-15-2$ 


\section{CONDITIONS LIMITING THE ACCURACY OF THE MAP.}

In using the geologic and topographic map (Pl. I) which accompanies this report the conditions limiting its accuracy should be thoroughly understood and the following facts kept in mind:

The land lines shown on the maps have not been resurveyed. Wherever the original section or township corners could be found their position with relation to the topography was determined. Only a few of them were discovered, however, and the net of the land lines has in the main been constructed from the maps and notes of the original surveys and superimposed upon the topographic map. The relationship of the net of land lines to the topography is therefore probably not accurate, for it is impossible to effect an exact adjustment from the few corners whose position was accurately determined; moreover, many of the original surveys of the public lands were very poor.

The position of the structure lines and of the contacts between various formations were located in the field with relation to the topography and drainage and to houses, roads, and other features of the culture, but not with special reference to the land lines.

Wherever reference is made in the text to townships and sections such reference applies to the land net as it is drawn on the topographic map.

The time spent in the Tesla quadrangle (Pl. XIV) was very short and the work there little more than a reconnaissance. As great a . degree of accuracy in the mapping of this area as in that of other parts of the region therefore can not be expected.

\section{PLACE NAMES.}

As but little investigation has been carried on in this region and as it is for the most part sparsely settled, many of the natural features are unnamed and many others have designations that are indefinitely applied or that are known only to a few persons. Study and discussion of a region are greatly handicapped by a lack of definite place names, and therefore for convenience and accuracy in reference new names are here proposed for a number of features for which no local name could be discovered. All these place names are shown on the accompanying map. The new names as well as those which usage had not entirely fixed were referred to the United States Geographic Board, and the names appearing on the map have been approved by that board. The names of a few of the features that will be mentioned frequently in the text are defined below.

Arroyo Ciervo.-The gulch and intermittent stream that heads at Ciervo Mountain and drains northeastward through the dry hills, entering the San Joaquin Valley in the northeast corner of sec. 29, T. 16 S., R. 14 E. 
Arroyo Hondo.-The first large creek in the foothill belt north of Cantua Creek, emptying into the San Joaquin Valley in sec. 3, T. 17 S., R. 14 E., about 4 miles north of Cantua Creek.

Big Blue Hills.-The belt of foothills extending along the San Joaquin Valley from Cantua Creek on the northwest to Joaquin Ridge on the southeast. On the southwest side this belt of hills is bounded by the mountain slopes. This name is applied for the reason that the central and most prominent summits in the group are high, domelike hills of light-blue color formed of serpentine fragments derived from the beds locally known as the Big Blue and called in this report the Big Blue serpentinous member of the Vaqueros formation.

Cantua Creek.-The important stream course that drains eastward to the San Joaquin Valley from the San Carlos division of the Diablo Range. It empties into the valley in sec. 36, T. 17 S., R. 14 E.

Cedar Flat.-A small valley eroded in the belt of Cretaceous shale and soft sandstone in the Griswold Hills, north of The Vallecitos. It lies in secs. $21,22,27$, and 28 , T. 16 S., R. $11 \mathrm{E}$.

Cerro Bonito Ridge.-The ridge dividing the valley of Pimental Creek from Panoche Valley. This ridge lies mainly in the north half of T: 16 S., Rs. 9 and 10 E., and is virtually the westward continuation of the Griswold Hills, from which it is separated by Griswold Canyon.

Ciervo Hills.-The group of hills around Ciervo Mountain, comprised in that portion of the foothill belt which extends from Cantua Creek to Tumey Gulch. This triangular hill group is bordered on the south by the lower course of Cantua Creek and by the foot of the main mountain range along the upper course of that creek; on the west by San Carlos Creek, in the vicinity of New Idria, and by Tumey Gulch; and on the northeast by the San Joaquin Valley. (See Pl. X, p. 82.)

Ciervo Mountain.-The highest point in the outer foothills between Cantua and Panoche creeks. It is situated in the northwest corner of T. 17 S., R. 13 E.

Corral Hollow Creek.-The large creek heading in the mountainous region on the west side of Oso Ridge and draining northwestward to Tesla, near which it turns sharply and, flowing eastward, empties into the San Joaquin Valley in sec. 19, T. 3 S., R. 5 E.

Crow Creek.-The large creek heading on the eastern flank of Lone Pine Ridge and emptying into the San Joaquin Valley in sec. 31, T. 6 S., R. 8 E., 3 miles southwest of Crows Landing.

Domengine Creek.-The creek heading near the Joaquin Rocks, draining the southeastern arm of Ragged Valley, and emptying into the San Joaquin Valley in sec. 26, T. 18 S., R. 15 E:, about 7 miles 
south of the mouth of Cantua Creek. The creek is named for Adolf Domengine, one of the early settlers in this region.

Garzas Creek.-The large creek emptying into the San Joaquin Valley in sec. 18, T. 8 S., R. 8 E., about 11 miles north of San Luis Creek.

Griswold Canyon.-The canyon in the east half of T. 16 S., R. 10 E., connecting the west end of The Vallecitos with Panoche Valley. The canyon has been termed variously Griswold, Grizzly, and Lyon Canyon, but Griswold is believed to be the original name.

Griswold Hills.-The hills separating The Vallecitos and Panoche Valley and extending from Griswold Canyon eastward to the canyon of Silver Creek.

Hammonds Hill.-A prominent hill lying mainly in sec. 17, T. 5 S., R. 7 E., at the edge of the hills just north of the mouth of Puerto Creek. Named for W. J. Hammonds, an early settler in this region.

Hospital Creek.-The large creek emptying into the San Joaquin Valley in sec. 12, T. 4 S., R. 5 E., 7 miles southeast of the mouth of Corral Hollow Creek.

Indian Valley.-A small erosional valley in the southern portion of the Panoche Hills, draining into Panoche Valley in the west-central part of T. 15 S., R. 11 E.

Joaquin Ridge.-The large structural ridge running southeastward from the high summits at the crest of the Diablo Range, south of New Idria, through T. 18 S., Rs. 13 and 14 E., and T. 19 S., Rs. 14 and $15 \mathrm{E}$.

Joaquin Rocks.-Three prominent rocks of massive sandstone in sec. 33, T. 18 S., R. 14 E., at the crest of Joaquin Ridge. (See Pl. IV, $A$, p. 40.)

Laguna Seca Creek.-The intermittent creek draining the foothills between Ortigalito and Little Panoche creeks. It heads in the center of T. 12 S., R. 10 E., and empties into the San Joaquin Valley in sec. 18, T. 12 S., R. 11 E.

Larious Creek.-The creek heading along the crest of the Diablo Range west of New Idria and draining north to The Vallecitos.

Little Panoche Creek and Valley.-The creek and valley next north of Panoche Valley draining the east flank of the Diablo Range. (See Pl. XII, $B$, p. 104.)

Los Banos Creek.-The first large creek north of Ortigalito Creek, draining into the San Joaquin Valley in sec. 7, T. 11 is., R. 10 E., about 4 miles north of Ortigalito Creek.

Martinez Creek.-The first creek crossing the Big Blu. $\rightarrow$ Hills south of Salt Creek. It heads on Joaquin Ridge, drains a portion of Ragged Valley, and enters the San Joaquin Valley in sec. 17, T. 1E S., R. 15 E., $4 \frac{1}{2}$ miles southeast of the mouth of Cantua Creek. 
Monocline Ridge.-The line of hills that forms the front of the higher portion of the Ciervo Hills between Arroyo Hondo and Tumey Gulch. Along this line the moderate summit slope of the Ciervo Hills breaks sharply into a steep slope that faces the lower foothills. The topography thus reflects the structure of the underlying strata, which are bent along this line into a sharp monoclinal fold.

Moreno Gulch.-The large gulch which drains the east flank of the Panoche Hills and opens into the San Joaquin Valley in the northeasst corner of T. 14 S., R. 11 E., about 4 miles southeast of the mouth of Little Panoche Creek. "Moreno" is Spanish for brown and is an appropriate name, inasmuch as the brownish color of some of the strata in which the gulch is carved is a noticeable feature in these barren hills.

New Bedford well.-An oil well in the east end of The Vallecitos, in sec. 6, T. 17 S., R. 12 E.

Orestimba Creek:-The creek draining into the San Joaquin Valley in sec. 17, T. 7 S., R. 8 E., about 17 miles north of San Luis Creek.

Ortigalito Creek.-A large creek heading in the higher part of the Diablo Range, flowing northward through T. 12 S., R. 10 E., and northeastward through T. 11 S., R. 10 E., and emptying into the San Joaquin Valley about 13 miles north of Little Panoche Creek.

Panoche Creek and Valley.-Panoche Creek is the large stream course draining the higher part of the Diablo Range west of Llanada, running eastward through Panoche Valley and emptying into the San Joaquin Valley at Hayes station, in the NE. $\frac{1}{4}$ T. 15 S., R. 12 E. The lower 3 miles is sometimes incorrectly termed Silver Creek.

Panoche Hills. - The group of high hills northeast of the Panoche Valley. (See PI. XII, A, p. 104.) This group lies mainly in T. 14 S., R. 11 E., and the north half of T. 15 S., R. 11 E. It is isolated from the main range, being almost completely surrounded by Panoche and Little Panoche valleys and the San Joaquin Valley. On the south it may be considered as crossing the canyon of Panoche Creek and including the small hill group south of that stream, being bounded on the south by the road from Panoche to the San Joaquin Valley along Kinky and Silver creeks.

The Pimental and Pimental Creek.-The small structural valley that forms the westward continuation of The Vallecitos in the south half of T. 16 S., R. 10 E., and the creek that drains it. Pimental Creek flows southeastward and joins Griswold Creek in the southeast corner of T. 16 S., R. 10 E., at the edge of the area shown on the map (Pl. I, in pocket).

Puerto Creek.-The large creek flowing into the San Joaquin Valley. in sec. 21, T. 5 S., R. 7 E., 10 miles northwest of Crows Landing.

Quinto Creek.-The creek draining into San Joaquin Valley in sec. 14, T. 9 S., R. 8 E., about 5 miles north of San Luis Creek. 
Ragged Valley.-A small erosional valley between Joaquin Ridge and the Big Blue Hills. (See Pl. II.) It extends northwestward from the southwest corner of T. 18 S., R. 15 E., diagonally across T. 18 S., R. 14 E., to the divide between Salt and Cantua creeks.

Romero Creek.-The large creek draining into the San Joaquin Valley in sec. 26, T. 9 S., R. 8 E., 2 miles north of San Luis Creek.

Salado Creek.-The large creek heading near the crest of Lone Pine Ridge and draining into the San Joaquin Valley in sec. 12, T. 6 S., R. 7 E., about 5 miles northwest of Crows Landing.

Salt Creek.-The creek draining the northeast flank of Joaquin Ridge and emptying into the San Joaquin Valley in sec. 1, T. 18 S., R. 14 E., $1 \frac{1}{2}$ miles south of the mouth of Cantua Creek.

Sampson Peak.-The prominent peak (elevation 4,675 feet) formed by the metamorphic rocks of the Franciscan formation at their contact with the serpentine 2 miles southwest of New Idria.

San Benito Mountain.-The dome-shaped summit of the San Carlos division of the Diablo Range, about $3 \frac{1}{4}$ miles southeast of New Idria, in the NW. $\frac{1}{4}$ sec. 15 , T. 18 S., R. 12 E. This mountain is 5,258 feet in elevation and is the highest point in the Diablo Range.

San Carlos Bolsa.-A basin almost entirely surrounded by high ridges, about 2 miles east of New Idria, at the northeast foot of San Carlos Peak. It is approximately 2 square miles in area and is drained by the main east fork of San Carlos Creek, which has only a narrow outlet on the north. "Bolsa" is the Spanish word for pocket or purse and is locally applied to a similar small topographic basin on Cantua Creek.

San Carlos Creek.-The main head of Silver Creek. It starts in the high San Carlos division of the Diablo Range south of New Idria and flows northward past that town to its junction with Larious Creek to form Silver Creek, in sec. 8, T. 17 S., R. 12 E., in the east end of The Vallecitos.

San Luis Creek.- The large creek draining through the Rancho San Luis Gonzaga, at the east end of the Pacheco Pass, and emptying into the San Joaquin Valley in sec. 1, T. 10 S., R. 8 E.

Silver Creek.-The creek draining northward from the east end of The Vallecitos through the deep canyon between the Griswold and Tumey hills to the junction with Panoche Creek, near the edge of the San Joaquin Valley. The name is sometimes incorrectly used for the main stream clear to the San. Joaquin Valley, but the proper usage makes Panoche Creek the main stream and Silver Creek a tributary.

Tumey Gulch.-The deep arroyo crossing the foothill belt between Ciervo Mountain and Silver Creek and opening into the San Joaquin Valley in sec. 31 , T. 15 S., R. 13 E., about 5 miles south of the mouth of Panoche Creek. 
Tumey Hills.-The group of high hills extending northward between Tumey Gulch on the east and Silver Creek on the west. These hills are structurally part of the hill assemblage represented by the Ciervo Hills to the east and the Griswold Hills to the west, but they are separated from each of the other groups by a deep canyon.

The Vallecitos.-A structural valley lying at the northern base of the main ridge of the Diablo Range a few miles northwest of New Idria. It includes portions of two drainage basins, being crossed halfway from one end to the other by a low divide which separates the drainage that flows eastward in the east branch to Silver Creek from that which flows westward in the west branch to Griswold Creek.

\section{GENERAL TOPOGRAPHIC FEATURES.}

The Diablo Range is the easternmost of the parallel ranges that constitute the Coast Ranges in central California. It extends as a continuous mountain mass 20 to 35 miles in width from Carquinez Straits and San Francisco Bay southeastward to Polonio Pass, in the northeast corner of San Luis Obispo County and the northwest corner of Kern County. It forms the western boundary of the northern half of the San Joaquin Valley, from. which it rises through a zone of rolling foothills to an altitude of 2,000 to 5,000 feet above the valley floor. On the west side of the range lie San Francisco Bay, the fertile Santa Clara Valley, and the San Benito, Salinas, and Cholame valleys. The range constitutes a very effective barrier between these regions, and at only five points are there natural passes of fairly low altitude through it. These are Livermore, Panoche, and Pacheco passes, whose east ends are shown on Plate I; Estrella Pass, which leads northwestward from Coalinga up Los Gatos Creek; and the pass leading westward from Coalinga thro.ugh Waltham and Priest valleys. These passes are important topographic and structural breaks and divide the range into several fairly well defined portions. In the portion between Panoche and Estrella passes the Diablo Range reaches its greatest altitude, and near New Idria a considerable area of it lies more than 4,500 feet above the sea. The greatest altitude is attained in San Benito Mountain, 5,258 feet above the sea. Northwestward as far as Livermore Pass the central part of the range has a fairly uniform altitude, usually between 2,500 and 3,500 feet, though there are a few ridges and summits several hundred feet higher, as well as depressions of lower altitude at the passes mentioned. The greatest break is at Livermore Valley, where the summit of the pass is less than 740 feet in altitude. North of this pass the range is broken longitudinally into separate ridges, the highest of which is on the east and culminates in the prominent isolated peak of Mount Diablo, at an altitude of 3,849 feet. 
As a whole the range presents no striking diversity of relief. The surfaces are usually rounded, the crest line is undulating, and most of the summits do not stand out as true peaks. Notable exceptions occur in the elevated region south of New Idria, where the Cretaceous strata flanking the range give a pronounced rocky and serrate outline to the lateral ridges, and in the area south of Pacheco Pass, where there are numerous rugged prominences, of which Mariposa Peak, with an altitude of about 3,800 feet, is the highest.

The topographic development of the range is youthful, and the surface configuration reflects to a mârked degree not only the greater but also many of the lesser structural features of the region. This aspect is well shown toward the south end of the range, where, although the range is in a broad way anticlinal, it is by no means a simple fold but rather an assemblage of folds and faults, many of which trend obliquely to its course. The oblique folds find their expression at the surface in ridges that extend to the southeast from the main range and, gradually decreasing in. altitude, sink to the level of the San Joaquin Valley. Between these ridges and the main range are structural valleys such as Pleasant Valley at Coalinga, The Vallecitos, and Panoche Valley. Pleasant Valley joins the San Joaquin Valley, but the other two are inclosed within the foothills. The oblique folds are important because they determine not only the surface configuration but also to a large extent the position of the areas in which oil is likely to have accumulated. Within the area covered by the map there are two well-developed examples of such oblique structural ridges-Joaquin Ridge and the ridge separating The Vallecitos from Panoche Valley. The Panoche Hills, which are almost isolated from the main range, owe their existence in part to a somewhat similar structure. North of Little Panoche Creek the main range, considered broadly, is more nearly a true anticlinal fold, although its regularity is somewhat disturbed, especially toward the north end, by normal faults. In this part of the region the oblique spur ridges that are so prominent toward the south are lacking.

The region examined and shown on Plate I falls naturally into three topographic divisions-(1) the western edge of the broad floor of the San Joaquin Valley; (2) the foothill belt, which through much of its extent is sharply defined from the higher hills; and (3) the main ridges forming the higher hills or mountainous part of the range.

The San Joaquin Valley is a broad, gently sloping alluvial plain separating the Coast Ranges from the Sierra Nevada. Near Livermore Pass, at the north end of the region here discussed, the valley is some 30 miles in width, but opposite the south end of the region it is almost 60 miles wide. Near Tracy the center of the valley is about 20 feet above sea level. Opposite Coalinga, 130 miles to the south, the elevation of the center of the valley is approximately 200 feet 
above sea level. The average slope of the western half of the valley toward its center is less than 20 feet to the mile near Panoche Pass and about 50 feet to the mile near Livermore Pass. This slope gradually increases toward the foothills, finally merging with the steeper slopes formed by the alluvial fans of the numerous small valleys and gulches that cut the Diablo Range. Along a portion of the foothills the change in slope is so gradual that it is impossible to say where the plain ends and the foothills begin.

The foothills form a belt of rolling hills, in places narrow but for the most part several miles in width. They are best developed in the south end of the region, where the belt has a maximum width of about 13 miles. South of Pacheco Pass these hills are in general rather sharply separated from the main range, but north of that pass through much of the distance the increase in altitude from the edge of the valley to the mountainous part of the range is very gradual. In the southern part of the region, where the foothills are well defined, their higher portions generally reach elevations between 1,000 and 3,000 feet above sea level, or between 700 and 2,500 feet above the level of the western edge of the San Joaquin Valley. The highest point in the true foothill belt is Ciervo Mountain, which is 3,393 feet above the sea. In the northern part of the region the foothills form in general a narrower belt and are much lower. The foothills owe their existence primarily to the same forces that produced the folding and uplifting of the whole range, but they represent the border zone in which these forces were less intense. The strata forming the hills are younger than those composing the center of the range, thus indicating the lesser amount of displacement that this belt has undergone compared with the higher parts of the range. The structural features produced by this original deformation of the strata exert a marked control over the major features of the topography, as illustrated by the topographic reflection of the trend of the structures in the trend of the hills themselves, and the reflection of zones of uplift in belts of high relief and of zones of depression in areas of low relief. By far the greater number of the minor features, however, such as ridges, hills, narrow valleys, and drainage lines, are the result of erosion acting under the combined control of the structure and relative resistance of the various beds. The strata are usually so soft as to have lent themselves readily to erosion. The rainfall of the region is light, but the lack of erosional force that would be the natural effect of meager rainfall is offset by the concentration of the rain during short periods and the bareness of the rocks, factors which facilitate the attack of disintegrating agencies. The hills are so barren of vegetation, except for the herbaceous plants that wither in the summer, that the most minute detail of the sculpture is visible and every part of the hills is readily attacked by falling and flowing 
water, wind, and gravitational force. In the southern part of the region the surface is much dissected by the streams, which have entrenched themselves deeply, cutting canyons with steep sides separated by narrow ridges. Remnants of former terraces appear locally on these ridges. In the northern part the entrenching has been less deep, and between the streams are broad flat-topped hills showing extensive terraced surfaces. The effects of erosion are well shown in Plates II, V, VI, and XII.

West of the foothills rises the higher or mountainous belt forming the core of the Diablo Range, an area of markedly different topography from that of the foothill belt. The surface rises sharply, reaching a maximum altitude of 5,258 feet above sea level on San Benito Mountain, in the south end of the region. This summit is about 14 miles from the edge of the San Joaquin Valley, which there has an elevation of approximately 500 feet above sea level. In the same vicinity the western edge of the foothill belt lies about 4 miles east of the high summits and has an altitude of some 2,000 feet. The central portion of the range is formed of a variety of rocks which in many places weather to crags or small peaks, but viewed broadly the mountains of this region are only moderately rugged, having usually the form of large hills.

Only in the region south of New Idria does the mapped area include the summit of the Diablo Range. Generally only a portion of the east flank is shown, and in much of the region the area examined includes simply the foothills and the western edge of the San Joaquin Valley.

\section{CLIMATE, DRAINAGE, AND VEGETATION.}

This region partakes of the general character of the eastern flank of the Coast Ranges, being dry and poorly watered. It is sheltered from the sea winds by the intervening mountains, which intercept the lower winds and deprive them of much of their moisture before they reach this region. The moisture carried by the higher winds travels far to the east and is precipitated on the upper slopes of the Sierra Nevada. The average annual rainfall is about 9 inches and it is confined almost entirely to the winter months. The summer weather is very hot and dry, and any appreciable rainfall during the months from May to September is practically unknown. The weather during the remainder of the year is delightful, though late in the fall and in the winter it is so cold and rainy that living out of doors is not pleasant. The streams are intermittent, the smaller canyons and gullies containing running water only during or for short periods after heavy rains. The larger watercourses carry running surface water until late in the summer or early in the fall, after which the water sinks below the surface and is seen only in deep pools here and there. Except during the period of heavy winter rainfall the streams sink 


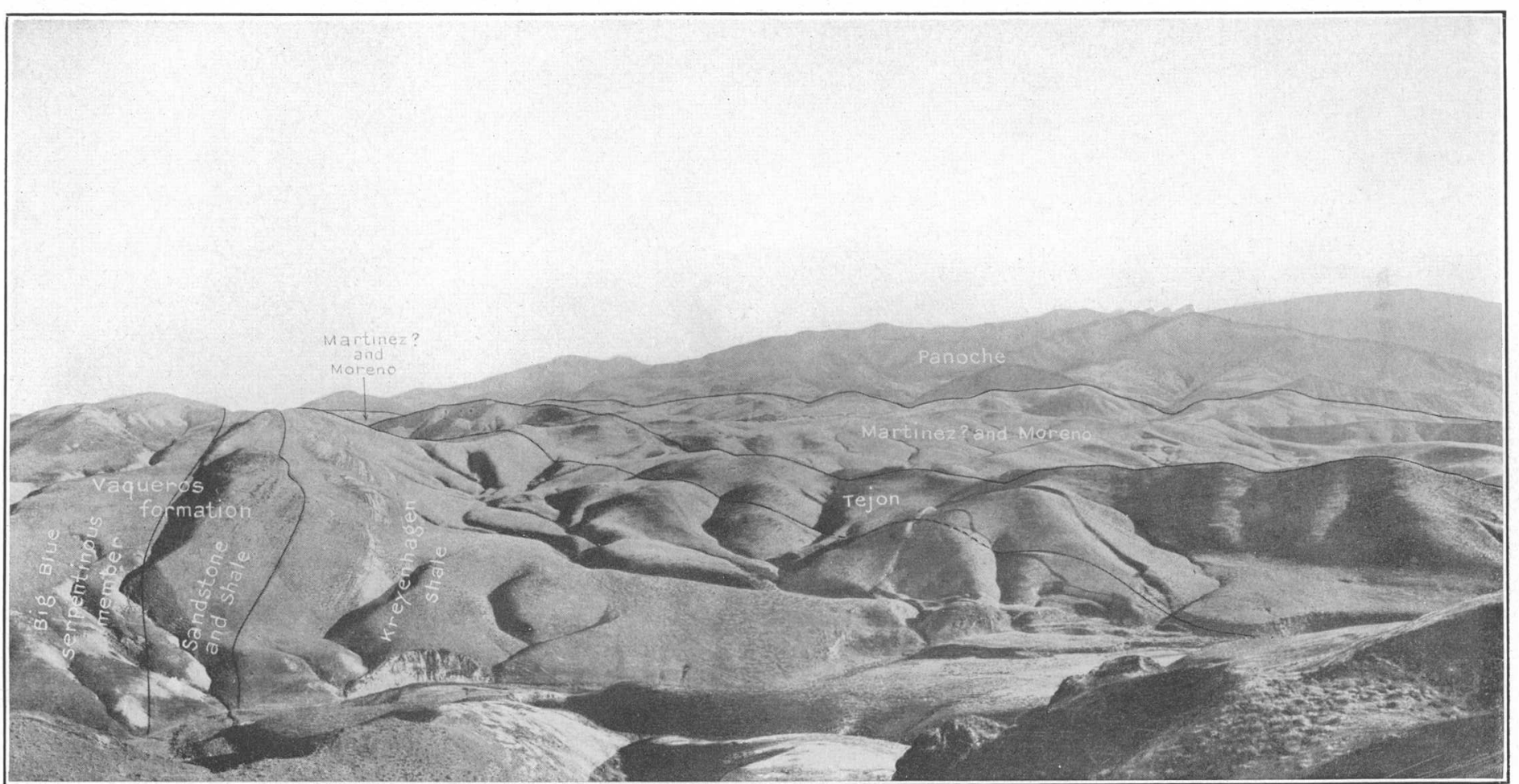

HILLS FORMED BY NORTHEASTWARD-DIPPING CRETACEOUS AND TERTIARY STRATA NORTH OF THE COALINGA DISTRICT,

Looking south along the central part of Ragged Valley from the north bank of Salt Creek. Note the subdued topography characteristic of the two shale zones and the large landslip in the foreground to the right. Joaquin Rocks are shown on the sky line to the right. 
below the surface before reaching the edge of the hills, the water finding its way thence beneath the surface of the San Joaquin Valley.

In the southern part of the region the foothills and the valley border are arid, and the land is used only for grazing or stands idle. The valley land would be excellent for agriculture if .water could be placed upon it, as will doubtless be found possible at some time in the future. Toward the north the degree of aridity lessens, and the valley land becomes suitable for cultivating without irrigation. In the foothills, however, throughout the region water is scarce, and all of it contains some mineral salts. Most of the streams and many of the wells afford water too highly charged with these salts to be suitable for drinking.

The region as a whole is poorly covered with vegetation. The broad plain along the west side of the San Joaquin Valley is practically treeless, except for a few shade trees about the scattered ranch houses. Aside from the portion under cultivation, the plain is covered only by a scattered growth of small shrubs and herbaceous plants. This condition prevails as far north as Pacheco Pass. . Northward from this pass the valley is under cultivation up to the edge of the hills, and in the summer and fall the alternating squares of plowed "summer fallow" and dry stubble, stretching out for miles to the north, east, and south, produce a monotonous checkerboard effect.

The foothills bear vegetation similar to that of the plain. Except along the few principal creeks, they are for the most part barren of trees and are covered with a locally sparse and locally rich growth of grass, herbaceous plants, and some dwarf shrubs. (See Pls. II, V, VI, X, and XII.) Cottonwood, willow, and sycamore trees, and wild tobacco grow along the few large streams. A few oaks cluster on the north slopes of the higher foothills in the northern part of the region.

The higher hills are the only portions of the region in which trees are at all numerous. Even here they are usually not thickly set, nor are they of any great size, being mostly live.oak, small pine, juniper, and white cedar. (See Pl. IV, A.) Locally, however, especially in the elevated portion of the range south of New Idria, good-sized pines and cedars are plentiful; and some timber is cut. The undergrowth is scant where the trees are most numerous, the woods being open and the soil grassed. Portions of the range where the trees are not thickly set, however, carry a thick growth of chaparral, so dense that it can be penetrated only with great difficulty.

\section{STRATIGRAPHY.}

\section{GENERAL. STATEMENT.}

The eastern flank of the Diablo Range between Coalinga and Livermore Pass is formed mainly of a thick body of marine sedimentary rocks, dipping toward the San Joaquin Valley. It contains some areas of igneous and metamorphic rocks and nonmarine sedimentary 
rocks, and there are local folds, but the first statement describes the predominant features in the structural make-up of the region. The

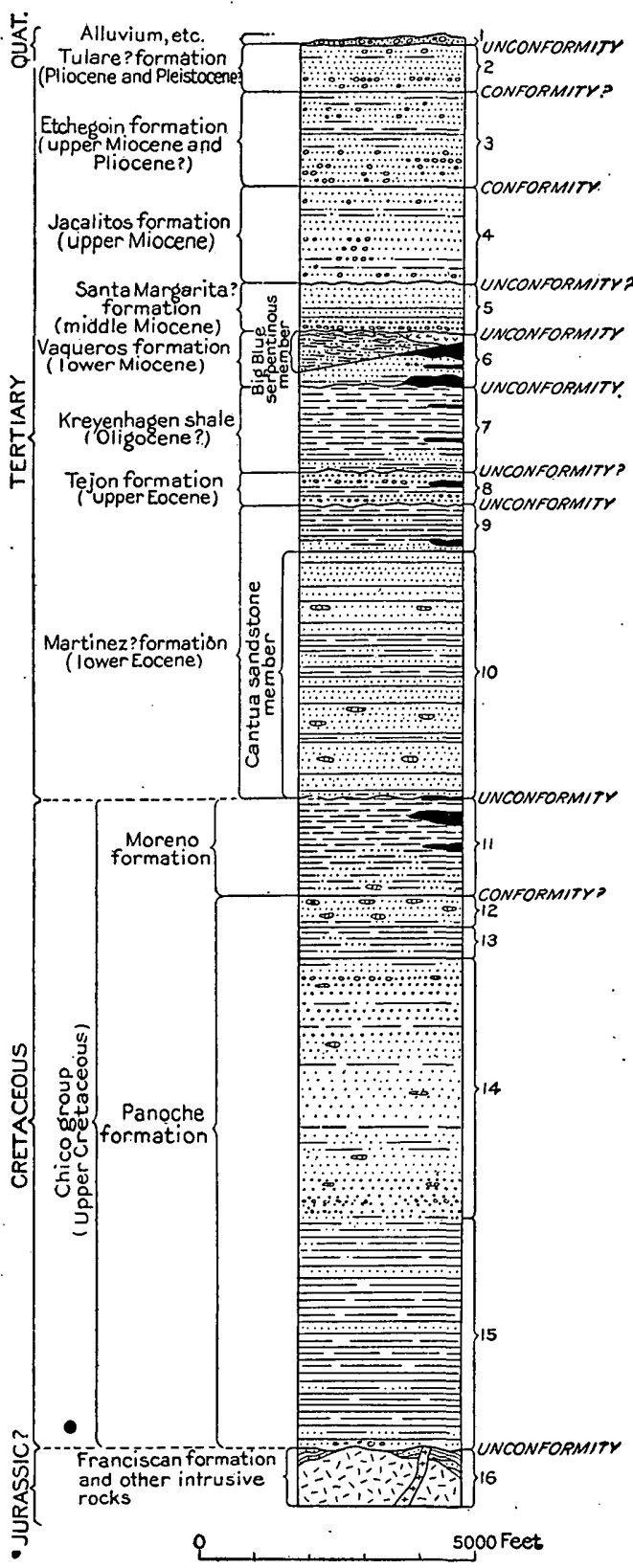

FIGURE 2.-Generalized columnar section of the rocks in the Diablo Range, in the southern part of the region between Coalinga and Livermore Pass. For description see page 27. oldest rocks have been exposed by erosion along the axis of the range, eastward from which, toward the valley, successively younger beds are exposed. This succession of strata comprises numerous formations, ranging from supposed Jurassic to Recent. The areal extent of the formations is shown on the geologic maps (Pls. I and XIV).

The columnar sections (figs. 2 and 3) give graphic generalized statements of the lithologic character and stratigraphic relations of the strata in the region under discussion.

\section{JURASSIC (?) SYSTEM.}

\section{FRANCISCAN FORMATION. \\ GENERAL FEATURES.}

The oldest rocks in the Diablo Range are comprised in the Franciscan formation, an assemblage of rocks of supposed Jurassic age, but of widely different types, which outcrop in a belt from 2 to 25 miles wide extending along the central portion of the range nearly from one end to the other. Except for a small area west of Coalinga, the belt of outcrop is continuous from the south side of Livermore Valley southeastward to Castle Mountain, near the south end of the 


\section{Beds represented in figure 2.}

1. Gravel, sand, and clay forming the filling of the Great Valley and of the valleys of the small streams; also terrace deposits and residual soil.

2. Unconsolidated clayey brown sand and clay, with numerous pebble layers and lenses that contain many fragments derived from the early Miocene and older beds. Near the base some of the sands are cemented by lime and gypsum and weather out rather prominently from the softer beds. May be partly of fresh-water origin but probably in large part subaerial deposits.

3. Loosely consolidated bluish and brownish sand and greenish and reddish clay, with numerous irregular beds or lenses of well-rounded pebbles, mainly of igneous rocks. The upper part is less consolidated and more clayey than the lower, the blue sandstone being much more prominent toward the base. Most of these beds are of marine origin and in the Coalinga region, to the south, contain numerous fossils. Some are terrestrial deposits and contain fossil remains of vertebrate animals.

4. Loosely consolidated sandstone, sand, and clay of much the same character as the overlying beds, but pebbly bluish sandstone is more abundant. In the lower part alternating beds of reddish and greenish clay and clayey sand, with irregular lenses of coarse grayish gravel are prominent. Like the overlying formation, composed in part of marine and in part of terrestrial deposits.

5. Fine-grained brownish sandstone, in places pebbly and containing abundant marine fossils. Some hard calcareous fossiliferous beds weather to prominent reef-like outcrops. The basal bed is a heavy conglomerate formed largely of serpentine fragments.

6. Medium fine-grained to pebbly gray and blue very fossiliferous sandstone, diatomaceous shale, and clay shale. Along the edge of the Great Valley the upper part is composed of flakes, pebbles, and bowlders of serpentine; forming the Big Blue serpentinous member of the Vaqueros formation. These beds are mainly of marine origin, but a few are terrestrial deposits and contain fossil remains of land mammals. In Panoche Valley tuff and vesicular lava overlying the known Vaqueros are thought to be of lower Miocene age.

7. Marine diatomaceous and clay shale; somewhat sandy near the base and cut by numerous sandstone dikes.

8. Marine light-yellowish to brilliantly white sandstone, with minor amounts of light reddish-brown or chocolate-colored shale and irregular pebbly beds. Very fossiliferous and locally coal-bearing.

9. Marine black to greenish-gray clay shale, with fine sandy beds and lenses, which are most plentiful toward the base. Fossils are abundant, especially near the top.

10. Marine massive concretionary gray sandstone, with beds of dark-gray to black clay shale and some thin-bedded gray sandy shale. Eocene fossil mollusks occur sparingly.

11. Purplish or maroon thin-bedded to platy siliceous foraminiferal and diatomaceous shale, with beds of clay shale and a minor amount of somewhat concretionary sandstone in the lower part. Marine Upper Cretaceous fossils occur sparingly, usually in hard dark-gray calcareous nodules which weather pure white.

12. Fine-grained massive gray sandstone, weathering tawny yellow and containing large concretions of red-brown sandstone. Marine fossil mollusks occur very sparingly.

13. Marine black clay shale, with minor beds of fine-grained iron-gray sandstone and gray calcareous layers which weather light yellowish.

14. Marine massive fine-grained concretionary gray sandstone, with a minor amount of dark sandy shale and a few irregular lenses of conglomerate. The massive sandstone weathers to huge slablike outcrops.

15. Marine dark-gray to black clay shale with narrow beds of fine-grained iron-gray sandstone, yellowish calcareous layers, and local conglomerate bed near the base.

16. Thin-bedded clay shale, compressed gray sandstone, and glaucophane and other schists, with altered intrusive igneous rocks, mainly serpentine.

The horizons at which oil-bearing beds occur are marked in black. 


\section{Beds represented in figure 3.}

1. Gravel, sand, and clay forming the filling of the Great Valley and of the valleys of the small streams; also terrace deposits and residual soil.

2. Unconsolidated brownish sand, clay, and coarse ill-sorted gravel formed of fragments derived largely from the pre-Tertiary beds in this region. Marl and thin discontinuous beds of impure fresh-water limestone locally form a small part of the section. Chiefly subaerial deposits, probably formed in much the same way as the present filling of the Great Valley. The tuff and vesicular basalt near Pacheco Pass were formed at either this or a later period.

3. Bluish sandstone, coarse conglomerate composed of pebbles of various igneous rocks, white tuffaceous sand, indurated greenish clay, and locally, near the base, coarse white sandstone filled with subangular fragments of red chert. Contains abundant fragments of white diatomaceous shale derived from the Kreyenhagen shale. Composed in part of marine deposits and in part of subaerial deposits.

4. Coarse-grained to pebbly, rather incoherent white sandstone, with a little clay and clay shale and numerous pebbly layers, also fine-grained carbonaceous gray sandstone, all containing marine fossils.

5. Marine white or light-brownish diatomaceous and foraminiferal shale bedded with a little fine-gray sandstone and cut by numerous dikes of fine-grained gray sandstone.

6. Marine very fine grained gray clayey sandstone and sandy shale, fossiliferous at several horizons. Stained reddish and hardened in irregular beds by iron oxid, and locally coal bearing.

7. Gritty yellowish sandstone, in places somewhat concretionary and containing irregular pebbly layers. Irregular beds are highly calcareous and filled with marine Upper Cretaceous fossils.

8. Thin-bedded to platy purplish or maroon siliceous foraminiferal and diatomaceous clay shale, bedded with fine-grained grayish concretionary sandstone and cut by numerous sandstone dikes. Marine Upper Cretaceous fossils are fairly abundant.

9. Massive concretionary gray sandstone, platy or flaggy sandstone, shaly sandstone, a small amount of dark clay shale, and irregular beds or lenses of conglomerate formed mainly of well-rounded pebbles of quartzitic and porphyritic rocks, with a few huge irregular blocks of granitic and other igneous rocks. The conglomerate beds are more abundant in the lower part. Marine fossils are scattered through these beds.

10. Compressed gray sandstone, thin-bedded shale, reddish chert, glaucophane and other schists, together with acidic and basic lavas and intrusive rocks which are all more or less altered, some of them to serpentine.

The horizons at which oil-bearing beds occur are marked in black. 
range, a distance of 150 miles. The average width of the belt is about 6 miles in the south and 15 or 20 miles in the north. At Livermore Vailey the belt is interrupted, the Franciscan rocks being covered by later formations, but they are undoubtedly continuous beneath the later beds and reappear to the north in an area around Mount Diablo. This assemblage of rocks forms the basement upon which the later strata were laid down and underlies probably the whole of the range and adjacent portions of the San Joaquin Valley. It also constituted the land mass from which some of the Miocene and later sedimentary deposits were derived.

This complex is composed of many varieties of sedimentary, igneous, and metamorphic rocks mingled together. The sedimentary rocks include arkose sandstone, argillaceous shale, chert (probably in part of radiolarian origin), siliceous, thinly laminated shale intermediate in appearance between shale and chert, a minor amount of conglomerate, and partly metamorphosed arenaceous and argillaceous materials. Associated with these sedimentary rocks are igneous rocks of various types, some of which are apparently bedded with the sedimentary rocks and are the remnants of volcanic flows

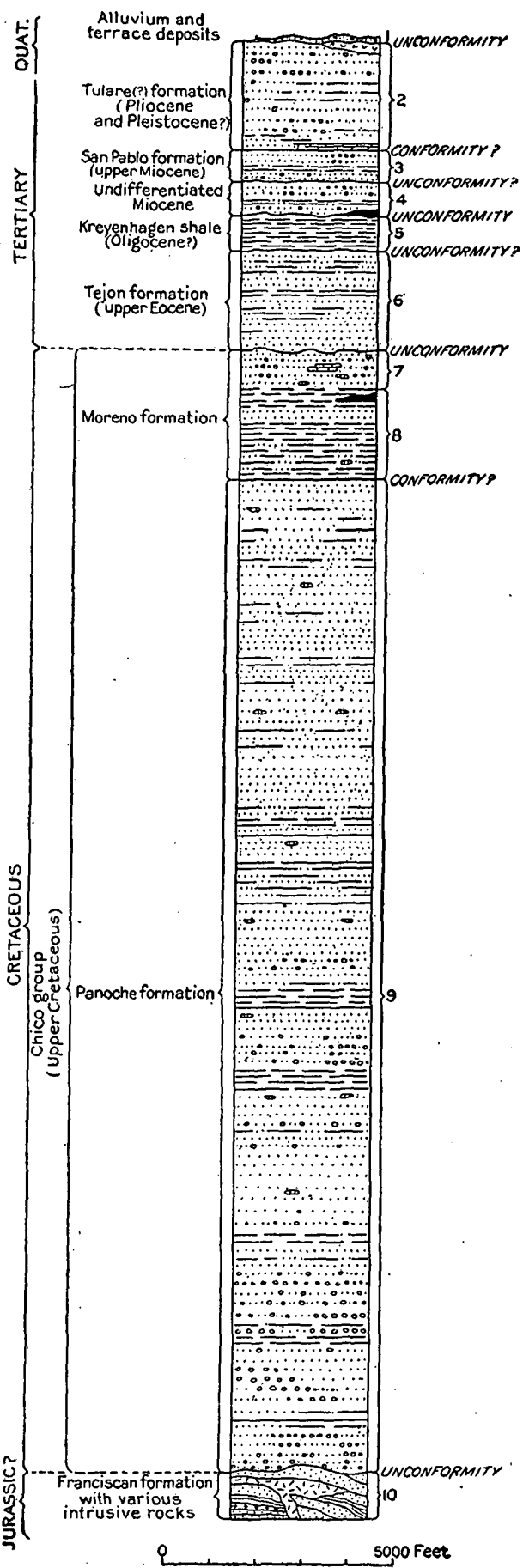

FIGURE 3.-Generalized columnar section of the rocks in the Diablo Range, in the northern part of the region between Coalinga and Livermore Pass. For description see page 28. 
that broke forth while the sediments were being laid down, whereas others are distinctly intrusive into the stratified rocks. In general, the igneous rocks are basic, common types being diabase, peridotite, gabbro, and greenstone, but acidic porphyritic rocks also occur. The bulk of the basic intrusives, probably for the most part peridotite originally, have been altered to serpentine. The intrusive rocks are not to be considered as part of the formation, but in many places they are not easily distinguishable. In most places the time available in the field did not permit a separation of the sedimentary and volcanic rocks of the Franciscan from the younger intrusive rocks. Except south of New Idria, where the serpentine has been mapped separately, the several areas of intrusive rocks have been grouped with the Franciscan on the geologic map.

In addition to the rocks already mentioned the formation includes large masses of metamorphic rocks of doubtful original nature, among which glaucophane and various related schists are the principal types. The formation has been intensely and intricately flexed and fractured, hardened by secondary silicification, and cut by intrusions, with the consequent production in places of schist of various types and of other altered rocks that present different stages of change from unaltered sedimentary and igneous rocks to truly metamorphic facies. In these respects this formation differs from the overlying Cretaceous and Tertiary strata, which nowhere show any such intense alteration.

The formation as a whole is similar to the terrane which has been termed Franciscan in the San Francisco Bay region and to the presumably equivalent rocks which are so common throughout the Coast Ranges in California and Oregon. In fact, it is a remarkable feature of the formation that, although it presents so great a variety. of rock types, the dominant types are identical, even to minute details, with those peculiar to the similar terrane elsewhere. No fossils have been found in these rocks within the region described in this paper, and very few indeed in the Franciscan elsewhere, so that there is no paleontologic basis for correlation. There can be little question, however, as to the general equivalence of the formation here described with the Franciscan on the San Francisco Peninsula and the similar rocks in neighboring portions of the Coast Ranges, owing to the characteristic association of rocks of peculiar types which afford a ready means of recognition, to the similar stratigraphic position, and to the fact that these rocks can be traced almost continuously from the type region to the Diablo Range and along that range to its south end.

In the greater part of the Diablo Range a separation between the Franciscan and the overlying strata can easily be made. Locally, however, where the Franciscan sedimentary rocks have undergone 
somewhat less alteration than usual, their resemblance to the overlying dark shale and arkose sandstone of the Cretaceous makes detailed study necessary for their separation. On general stratigraphic evidence obtained in the region under discussion it may be stated without question that there is a great unconformity between the Franciscan and the oldest Cretaceous rocks in this region. The Franciscan in other parts of California has been shown to be almost certainly pre-Cretaceous in age. The rocks resting upon the Franciscan through most of this part of the Diablo Range represent only the later portion of the Cretaceous period. The unconformity is further attested by the extensive metamorphism, the structural complexity, and the irregular distribution of the Franciscan, as opposed to the unaltered nature and fairly regular structure of the Cretaceous beds. These features indicate that the Franciscan was subjected to great disturbances and to erosion prior to the deposition of the next later strata here exposed.

In spite of this great unconformity, however, the Franciscan does not appear to have contributed much if any material to the Cretaceous formations. The formations in the Chico group (Upper Cretaceous) are made up largely of grains, pebbles, and bowlders derived from areas of granitic and acidic porphyritic rocks, the characteristic types of the Franciscan not being seen. There probably exists somewhere, possibly buried beneath the later formations in the topographic basins, a hitherto undiscovered mass of sedimentary rocks representing the material worn from the Franciscan and deposited during Cretaceous or pre-Cretaceous time.

\section{ECONOMIC IMPORTANCE.}

So far as known, the Franciscan rocks nowhere contain petroleum, and had they once contained it the amount of fracturing and deformation which they have suffered would hardly have allowed much of it to remain. Experience so far has shown that an area formed of Franciscan rocks can be at once condemned as possible oil-producing territory. Other minerals occur in the Franciscan rocks, however, and some of them, notably cinnabar, are at present of economic importance. Their occurrence is mentioned in another portion of this report.

GENERAL CHARACTER OF POST-FRANCISCAN ROCKS.

PRINCIPAL FEATURES.

To ordinary observation the beds of sandstone, shale, and conglomerate that overlie the Franciscan formation in this region seem conformable throughout and have the appearance of representing a period of continuous sedimentation. This appearance is due largely

S1.2S1 ${ }^{\circ}-$ Bull. $603-15-3$ 
to the fact that the latest earth movements have been of so 'great magnitude that the deformation of late Tertiary strata is apparently equal to that of much older beds. in which the later deformation is added to the results of earlier movements. However, by careful examination proof of breaks in the sequence of beds may be obtained, and the fact established that throughout several long periods sediments were not being deposited in this region. During such periods the beds that had been previously formed were raised above the level of the sea and suffered erosion. (See Pl. IX.)

Through most of the region this succession of beds can easily be separated from the Franciscan formation, but it can be divided into formations only by careful mapping of the various lithologic and paleontologic zones. In general the paleontologic evidences are the more trustworthy criteria for subdivision, for not only do the several zones usually show gradation in lithologic character both along their strike and from one zone to another, but at widely separated periods peculiar conditions governing deposition appear to have been repeated, resulting in the formation of the same kinds of beds at different horizons. The best examples of such recurring lithologic phases are the thick bodies of diatomaceous shale of almost identical appearance in the Moreno formation (Upper Cretaceous), in the Kreyenhagen shale (Oligocene?), and in the lower Miocene; the abundant peculiar tawny-weathering sandstone with huge brown concretions in the Panoche and Moreno formations (Upper Cretaceous), and in the Martinez (?) formation (lower Eocene) and the very similar beds in the Tejon formation (upper Eocene); and the peculiar light-blue sandstone which is very abundant and widespread in the upper Miocene formations, locally forms thick zones in the Vaqueros formation (lower Miocene), and is present also in the Kreyenhagen shale (Oligocene ?). The beds of these recurring phases at one horizon are separated from the similar beds at the next horizon by many hundreds of feet of beds of different type. These phases have led investigators astray in this region, each having been taken as characteristic of some particular formation. Except the Pliocene and more recent deposits, which are probably in the main of fluviatile or lacustrine origin, the post-Franciscan formations consist almost wholly of marine sediments. Igneous rocks are not abundant and occur only in three small areas south of Pacheco Pass in the form of intrusive bodies and flows of basalt. The intrusions took place in at least two epochs, the Miocene and post-Pliocene.

The succession of strata exposed in any one part of the region differs from that in every other part, owing to the variable conditions of sedimentation that existed from place to place, the small extent of the basins in which some of the formations were laid down, and the unconformable relations between many of the formations. The 
characters of almost all the formations vary so greatly that it is difficult to correlate the section exposed in one area with that shown in another only a short distance away. Thus the formations in the Cantua district, at the south end of the region under discussion, though in general the continuation of those in the Coalinga district, develop marked differences from them as they extend northward, just as the section near Coalinga exhibits a decided difference from that in the south end of the Coalinga district. Similarly the formations in the northern part of the region differ in many important respects from those in the southern part. The region may in fact, on the basis of these differences, be divided into two main provinces, one south and the other north of Panoche Creek. The general characters of the beds in these two parts of the region are shown in the two columnar sections (figs. 2 and 3 ) and a brief and somewhat generalized description of the strata as they appear in the two parts. is given below.

\section{FORMATIONS IN THE SOUTHERN AREA.}

The Franciscan formation south of Panoche Creek is overlain by alternating beds of thin-bedded clay shale and massive concretionary sandstone whose aggregate thickness is almost 9,500 feet. They are believed to be of Upper Cretaceous age and are here mapped and described as the Panoche formation, although the lowest beds are nonfossiliferous and their exact age is therefore not accurately determinable. The Knoxville formation (Lower Cretaceous) is believed to be absent unless it is represented by the nonfossiliferous beds just mentioned which rest upon the Franciscan in part of the region.

The Panoche formation is overlain conformably by the Moreno formation, also of Upper Cretaceous age and belonging to the Chico group. It is formed of foraminiferal and diatomaceous maroon and chocolate-colored shale and dark clay shale, with some interbédded sandstone, and has a maximum thickness of about 1,600 to 1,800 feet.

Overlying the Moreno formation unconformably is the Martinez (?) formation, of Eocene age. This formation is divisible lithologically into two parts-a huge lens of concretionary sandstone and interbedded shale, here termed the Cantua sandstone member, which forms its lower part within a small area, and a body of dark clay shale with minor amounts of sandstone, which constitutes the upper part of the formation but which also includes lower beds believed to be equivalent to the Cantua sandstone member where that is lacking. The maximum thickness of the Cantua sandstone is at least 4,500 feet; the thickness of the clayey member averages 450 feet, with a maximum of about 1,000 feet.

The Martinez (?) formation is unconformably overlain by beds of brilliant-white sandstone, with some brown carbonaceous shale and 
dark clay shale, which have a maximum thickness of at least 750 feet and which constitute the Tejon formation, of upper Eocene age.

The Kreyenhagen shale, probably of Oligocene age, formed of white and chocolate-brown diatomaceous and foraminiferal shale, and having a maximum thickness of a little over 1,500 feet, rests with probable unconformity upon the Tejon.

The Kreyenhagen shale is overlain with marked unconformity by rocks of lower Miocene age, which are the northward continuation of the beds mapped in the Coalinga region as the Vaqueros formation, except that in the area covered by the present report the beds locally known as the Big Blue, composed of flakes and bowlders of serpentine, have been included in the Vaqueros formation, instead of in the overlying Santa Margarita (?) formation as in the Coalinga district. The Vaqueros formation has a maximum thickness of about 1,000 feet and is iormed of coarse sandstone, locally thick beds of diatomaceous shale, and the beds $\mathrm{known}_{\mathrm{i}}$ in the region as the Big Blue, here termed the Big Blue serpentinous member.

The Vaqueros formation is overlain unconformably by beds of coarse sandstone and conglomerate, whose aggregate thickness is about 900 feet and which, with the exception noted above, are the equivalent of the beds mapped as the Santa Margarita (?) formation (middle Miocene) in the Coalinga district.

Resting with probable unconformity upon the Santa Margarita (?) formation are beds of interstratified clay, sand, gravel, and the indurated equivalents of these materials, which form the northward extension of the Jacalitos and Etchegoin formations (upper Miocene) of the Coalinga district. These beds have a maximum thickness of about 3,400 feet and are overlain with probable conformi y by somewhat similar beds, which are believed to be the equivalent of a part of the Tulare formation (Pliocene and Pleistocene?) as mapped in the Coalinga district, and whose maximum exposed thickness is about 800 feet.

\section{FORMATIONS IN THE NORTHERN AREA.}

In the area north of Panoche Creek the Panoche formation (Upper Cretaceous) has a maximum thickness of not less than 21,000 feet and rests unconformably upon the Franciscan formation.

The Panoche formation is overlain conformably by the Moreno formation (also Upper Cretaceous), which has a maximum thickness between 2,500 and 3,000 feet. Both of these Cretaceous formations contain the same general types of materials as in the region south of Panoche Pass, but in different proportions and in a changed zonal arrangement. The Panoche formation has a coarser and more uniform aspect and includes numerous zones, both thick and thin, of coarse conglomerate. The Moreno formation contains less of the 
shale of truly organic origin and more clay shale and sandstone than in the region to the south.

So far as yet determined from the paleontologic evidence, the Martinez formation (lower Eocene) is not present in the area north of Pacheco Pass, where the oldest beds resting upon the Moreno formation are of Tejon age (upper Eocene). The Tejon is here formed mainly of fine-grained gray clayey sandstone, but beds of fine-grained light-brown shale and gray clay are interstratified with the sandstone, and layers of coal occur in the lower portion. The formation has a maximum thickness of about 2,100 feet.

The Kreyenhagen shale overlies the Tejon formation and retains the character which it has in the southern area. Its maximum exposed thickness is 750 feet.

Certain sandstone beds described as undifferentiated Miocene follow next in the stratigraphic succession. They occur in three separated areas, one in Panoche Valley, one near Crow Creek, and one north of Tesla. In the Panoche Valley area these beds are at least 200 feet thick and consist of poorly consolidated sand and gravel. They rest upon tuffs and basaltic flows of probable lower Miocene age and are overlain by Pliocene or more recent gravel. In the Crow Creek area these beds consist of incoherent gray sandstone and clayey sand and have a maximum thickness of about 400 feet. They overlie the Kreyenhagen shale with probable unconformity and are unconformably overlain by the San Pablo formation (upper Miocene). In the Tesla area the undifferentiated Miocene beds consist of at least 700 feet of fossiliferous light-colored sandstone, which may or may not be equivalent to that near Crow Creek. These sandstone beds lie with discordant attitude upon the Cretaceous strata and are overlain by the beds described as San Pablo. They are probably of middle Miocene age.

The San Pablo formation, of upper Miocene age, which overlies the undifferentiated beds is composed of bluish sandstone, yellowish clay, white ash, and irregular beds of conglomerate, the whole having a maximum thickness of at least 700 feet.

Beds of coarse sand and gravel whose aggregate thickness is at least 2,300 feet overlie the San Pablo. They are considered as the probable equivalent of the Tulare formation in the soathern part of the region.

\section{CORRELATION.}

The post-Franciscan rocks have been described by a number of writers, who have grouped them into various formations. In many cases the strata included by the different writers in a given formation are somewhat different; also different formation names have been applied to the same succession of strata. Moreover, it has 
happened that some of the workers have published more than one paper describing the stratigraphy of this region and in the later papers have revised somewhat their original definitions of the formations. Thus, it is difficult, in describing the formations which are outlined above, to give concise references to previous descriptions of the strata embraced in those formations. The accompanying table (Pl. III) is an attempt to show graphically the correlations between the formations described by the different writers, between the original and revised descriptions of any writer, and particularly between the previously described sections and that given in the present report. Besides the present report the papers furnishing the data for the table are as follows:

Anderson, F. M., A stratigraphic study in the Mount Diablo Range of California: California Acad. Sci. Proc., 3d ser., Geology, vol. 2, No. 2, 1905.

Anderson, F. M., A further stratigraphic study in the Mount Diablo Range of California: Idem, 4th ser., vol. 3, pp. 1-40, 1908.

Arnold, Ralph, and Anderson, Robert, Preliminary report on the Coalinga oil district, Fresno and Kings counties, Cal.: U. S. Geol. Survey Bull. 357, 1908.

Arnold, Ralph, and Anderson, Robert, Geology and oil resources of the Coalinga district, Cal.: U. S. Geol. Survey Bull. 398, 1910.

The formation names used by the different writers and the time periods to which they were assigned are shown in the separate columns. No attempt has been made to draw the formation blocks to scale, but they are so placed that those which the present writers believe equivalent are an equal distance above the bottom of the column. Thus horizontal lines pass through formations which are believed to be equivalent. The correlations proposed by the various authors between the sections given by them for different parts of the region, or between the first and the second (revised) section given by them for the same portion of the region, are shown by dotted lines joining the adjacent columns. Thus a comparison of columns 1 and 2 will show the correlation proposed by F. M. Anderson in his first paper between the sections north and south of Coalinga; of columns 2 and 3 the difference between the original and revised sections proposed by F. M. Anderson for the region north of Coalinga; and of columns 6 and 7 the correlation proposed by Arnold and Robert Anderson in the Coalinga report between sections north and south of Coalinga.

\section{CRETACEOUS SYSTEM.}

\section{CHICOO GROUP (UPPER CRETACEOUS).}

\section{GENERAL CHARACTER.}

The Chico group (Upper Cretaceous), as mapped in this district, comprises a very thick body of sedimentary strata mainly if not wholly of marine origin and formed predominantly of detrital material derived from older rocks. The greater portion is composed of dark clay shale 
F. M. Anderson (1905)

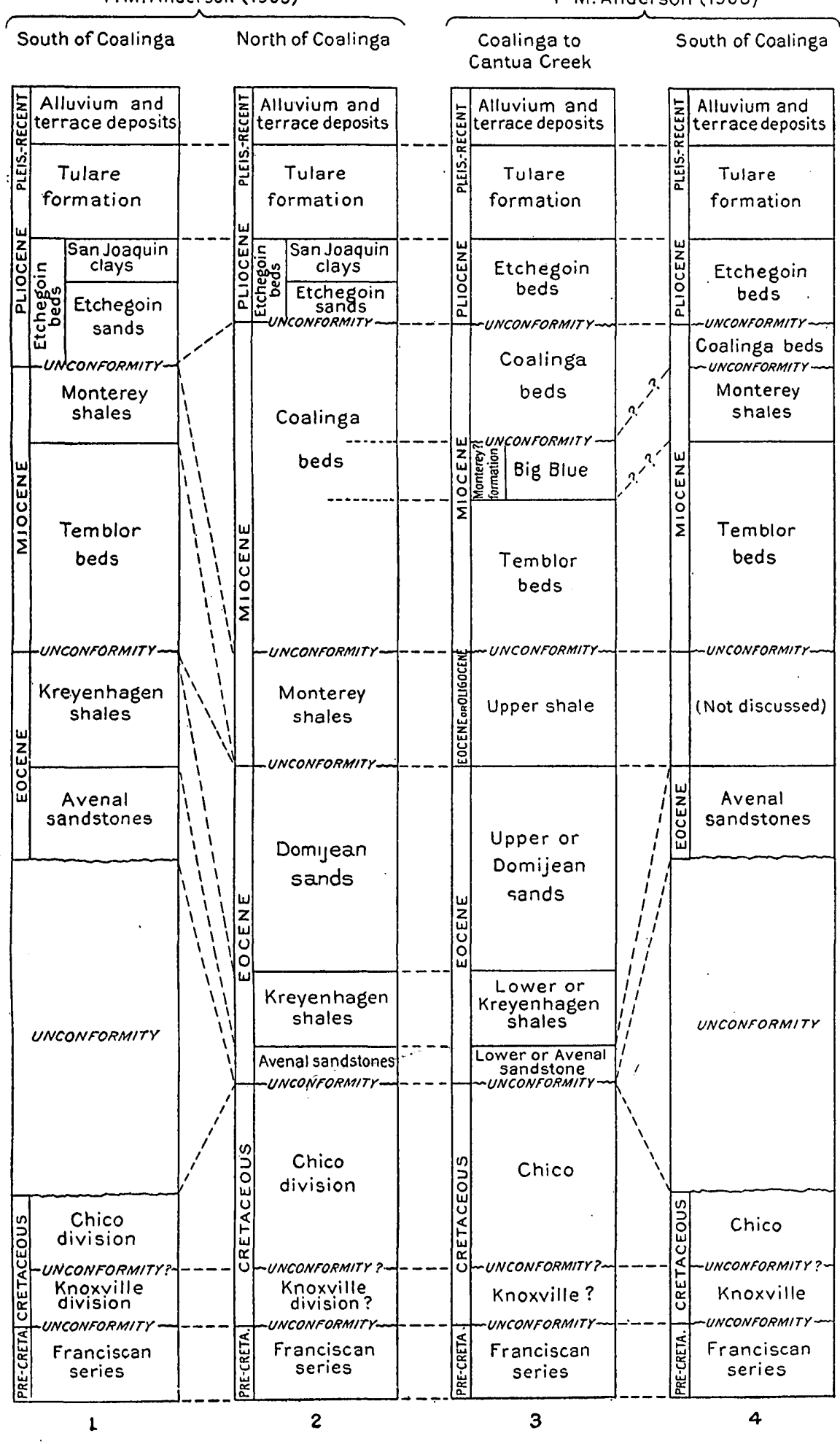

Ralph Arnold and Robert Anderson

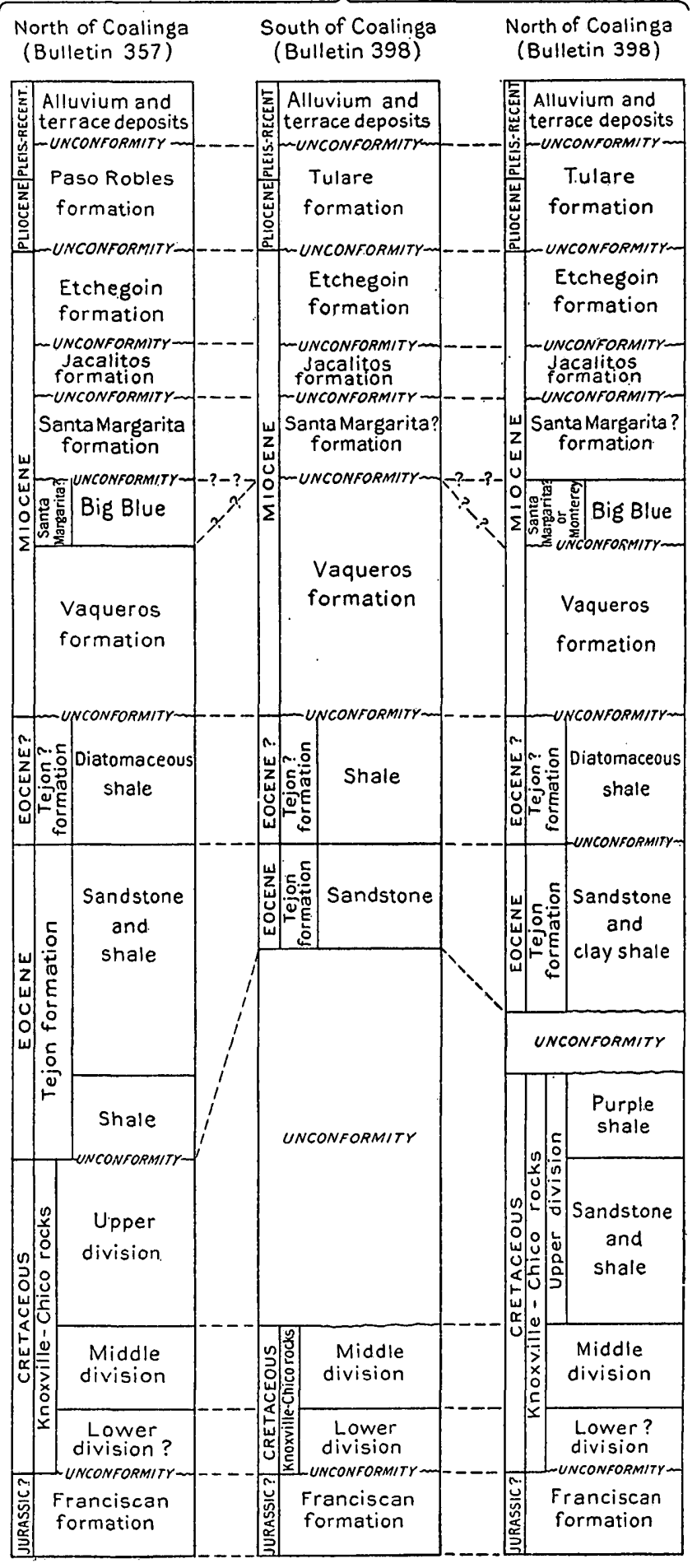

5

6

7

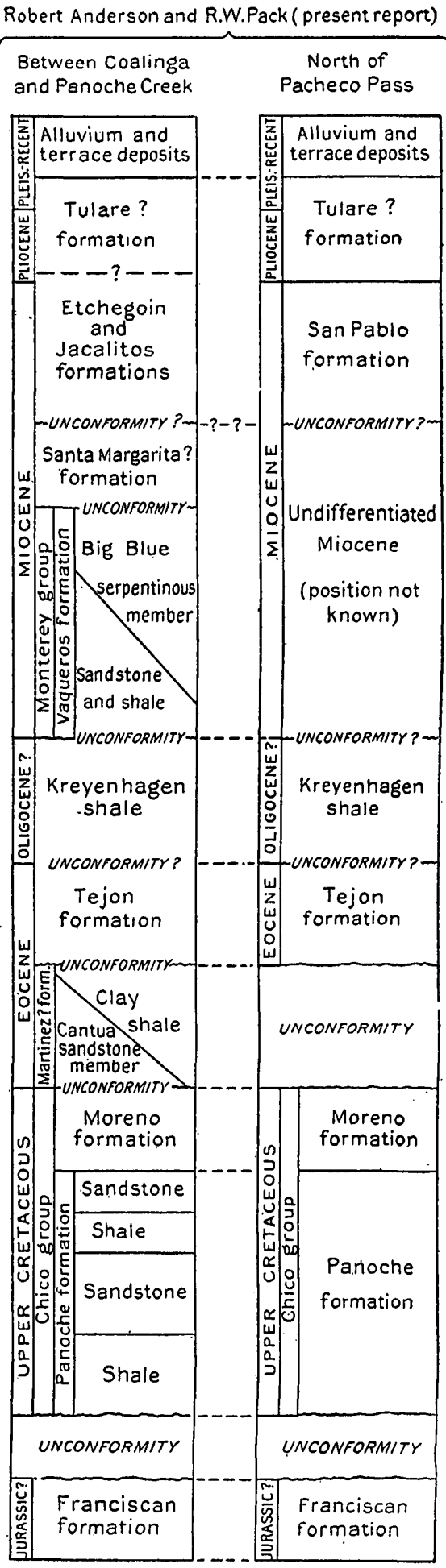

CORRELATION OF THE PRINCIPAL SECTIONS IN THE EAST FLANK OF THE DIABLO RANGE. 
and of thin-bedded to massive gray sandstone formed largely of quartz and feldspar but containing also many fragments of various quartzose and igneous rocks and filled with large, hard sandstone concretions. Besides these two main lithologic types the group includes arenaceous shale, platy sandstone, and beds of coarse conglomerate which locally attain great thicknesses. At the top of the group is a zone averaging about 2,000 feet in thickness which is formed largely of siliceous organic shale. In the southern part of the region single sections of Chico strata show a vertical thickness of over 7,000 feet, and a moderate estimate places the total thickness of these strata here about 11,200 feet. The factors controlling the deposition of these beds in the southern area seem to have varied from time to time, and different kinds of sediment resulted, but changes did not occur frequently, and there were long periods during which the conditions remained fairly constant. During such periods many hundreds or thousands of feet of sediments almost identical in lithologic character were deposited, and it is possible to differentiate sereral such lithologic divisions in the area southeast of The Vallecitos, along the east flank of the Diablo Range. In the area lying north of Panoche Valley single sections show the astonishing thickness of over 24,000 feet of interstratified sandstone, clay shale, shale of organic origin, and conglomerate. The conditions affecting the deposition of the Chico sediments there were extremely variable, and rocks of different lithologic types, such as coarse, poorly sorted conglomerate, even-grained sandstone, fine clay shale, and shale of organic origin, are intermingled. It was not found possible to outline in this area lithologic divisions comparable with those in this group to the south. The great bulk of the material is probably of marine origin, but a portion of the material deposited north of Pacheco Pass may possibly be of fluviatile origin.

In most of the region fossils believed to be characteristic of the Chico (Upper Cretaceous) were found in the beds that rest upon the Franciscan, thus indicating the Chico age of the lowest strata in the Cretaceous section. In small portions of the region, however, no fossils have yet been found in the lower part of the exposed Cretaceous section, all of which is mapped and described with the Chico group. The age of these nonfossiliferous beds is not yet definitely determinable and it is possible, though not believed probable, that some of them may be Lower Cretaceous. The beds regarding the age of which some doubt may be entertained have their greatest development on Joaquin Ridge, where no fossils were discovered in the lower 2,000 feet of a homogeneous body of shale about 4,000 feet thick. The upper part of this shale contains Chico fossils, however, and the whole is probably. Chico. Finally, in the Tesla area, where the work was a reconnaissance only, a narrow belt of outcrop of beds in which Knox- 
ville or Horsetown fossils have been reported is mapped with the overlying Panoche formation.

With the possible exceptions just noted, all these beds are of Upper Cretaceous age, as shown by the fossils which may be found, rather sparingly, from bottom to top. At least a portion of them were deposited during the time when the Chico sediments in the Sacramento Valley were laid down. It is, however, impossible to say just how much of the section here is the stratigraphic equivalent of the Chico formation in northern California.

In the original description of the Chico ${ }^{1}$ no definite type locality was designated, the name being applied to Upper Cretaceous strata occurring on both sides of the Sacramento Valley and along the west side of the San Joaquin. Valley. The name is now commonly employed to designate all Upper Cretaceous strata on the Pacific coast from British Columbia to Lower California that are younger than the Horsetown formation (Lower Cretaceous) and older than the Martinez formation (lower Eocene). It is in this sense that the term Chico is used in the present report.

Although most of the lithologic divisions can not be followed any great distance, one of them, occurring at the top of the Cretaceous, is traceable throughout the region and has been separated as the Moreno formation. The strata below this division have been grouped together as the Panoche formation. With further work it may be found possible to divide one or both of these formations into parts, some of which may be of formational value and which may be separated by unconformities. For the present, however, whatever divisions have been made are treated as members of the formations mentioned above.

The type sections of the Panoche and Moreno formations are in the Panoche Hills between Panoche and Little Panoche valleys. This locality is chosen because here both formations are well developed and exposed in the same section, and the Cretaceous section as a whole is almost if not quite as thick and complete as it is at any other locality in the region; because the locality is fairly central with respect to the distribution of the formations; and because the main lithologic features distinguishing them are here well represented. These features, as well as the paleontologic evidence, make certain the correlation of these formations with the similar beds to the north and south.

Heretofore those who have studied the geology of this region have grouped together all the beds which they recognized as Upper Cretaceous in age, correlating them with the Chico formation. Most of these workers have failed to recognize the Cretaceous age of the beds here mapped as the Moreno formation. Some have even stated 
that beds in the upper part of the section, described in the present report as the Panoche formation, are of Tertiary age. For instance, F. M. Anderson ${ }^{1}$ considers the concretionary sandstone forming the uppermost member of the Panoche formation in Ragged Valley and in the north end of the Coalinga district as basal Eocene. Except in the second report by the United States Geological Survey on the geology of the Coalinga district, ${ }^{2}$ in which Arnold and Robert Anderson group together as the Chico formation the beds mapped as the Moreno and Panoche formation in the present report, the term Chico has been applied to practically the same assemblage of strata as are included by the present writers in the Panoche formation. As the Upper Cretaceous age of the Moreno formation is unquestionable these beds must under the commonly accepted definition be classed as Chico. However, as the field work in the region under discussion has shown that the purplish shale of organic origin and allied beds which are mapped as the Moreno formation are a rather distinct lithologic unit; that they are of considerable thickness and great persistency, and that they have a direct bearing on the economic possibilities of the region, the writers feel fully justified in mapping them as a distinct formation. It therefore becomes necessary to consider the Chico in this region as a group which comprises two formations-the Moreno and the formation composed of the Upper Cretaceous strata underlying the Moreno, to which the term Panoche is applied.

\section{PANOCHE FORMATION.}

GENERAL FEATURES.

The Panoche formation, which is the lower of the two formations composing the Chico group, comprises all the Upper Cretaceous strata lying below the maroon and associated beds that constitute the Moreno formation. It embraces beds of diverse lithology, varying from extremely fine clay shale to beds composed of bowlders some of which have a diameter of several feet. In a considerable portion of the region its aggregate thickness is over 20,000 feet. The name is derived from the Panoche Hills, in which these beds are well developed and exposed and which afford the type section for both the Panoche formation and the overlying Moreno. A descrip- . tion of the formation in those hills is given in the discussion of its distribution north of Panoche Creek.

The Panoche formation as mapped rests unconformably upon the Franciscan formation. The line of separation is almost everywhere easy to follow, both because of the unique lithology of the older rocks and because of the greater amount of folding and crushing which they show. The line of separation between the Panoche and

${ }^{1}$ California Acad. Sci. Proc., 3d scr., vol. 2, No. 2, p. 167, 1905.

2 U. S. Geol. Survey Bull. 398, pp. 51-62, 1910. 
the overlying Moreno formation is not sharp, the lower sandy beds apparently grading upward into the shaly beds through a zone of mingled shale and sandstone, and it is believed that there was no break in sedimentation between the two. The line of separation that is mapped is arbitrary, and owing to the irregular commingling of shale and sandstone in the intermediate zone it is almost impossible to follow any consistent horizon line. The faatures of the Panoche formation south of Panoche Creek are somewhat different from those north of it, and hence the two areas will be described separately.

\section{AREA SOUTH OF PANOCHE CREEK.}

The Panoche formation along the foothills of the main range south of The Vallecitos is divisible into four members, which are alternating layers of clay shale and concretionary sandstone. The lowest member is formed of iron-gray to black clay shale and sandy shale with a small amount of thin-bedded, fine-grained brownish to iron-gray sandstone. This member is the northward continuation of the shale that was described in the Coalinga report as the middle division of the Knoxville-Chico rocks. Near the head of White Creek, southeast of Condon Peak, these beds dip steeply to the south on the south limb of the Coalinga anticline. Their thickness at this place is not less than 4,000 feet. At the headwaters of Salt Creek, on the north limb of the fold, the thickness is probably about the same. To the northwest the thickness rapidly decreases, and at New Idria it is in places hardly more than 500 feet. This thinning may be due in part to faulting along the Chico-Franciscan line, and there is ome evidence that this line near the New Idria mine is a fault. It is believed, however, that the thinning is due in the main to differences of deposition and to a gradual lessening westward in the amount of sediment laid down during this epoch. A similar northwestward thinning is shown by the succeeding concretionary sandstone member of the Panoche formation. Typical Chico (Upper Cretaceous) fossils occur sparingly in the upper half of this lower shale member on the south flank of Joaquin Ridge. ${ }^{1}$ Its basal part may possibly be older than Chico, as already suggested, but this is not believed probable.

From Joaquin Ridge to a point near New Idria the lower shale member is overlain by a thick member composed largely of concretionary sandstone. The contact between the two members is irregular and has been a line of more or less minor faulting, but wherever the contact is normal all the evidence indicates that deposition was continuous and that the shale grades into the sandstone through a zone, usually 100 or 200 feet thick, of interstratified thin-bedded clay, shale, and sandstone. The concretionary sandstone member is com-

1 Geology and oil resources of the Coalinga district, Cal.: U. S. Geol. Survey Bull. 398, p. 60, locality $4,1910$. 


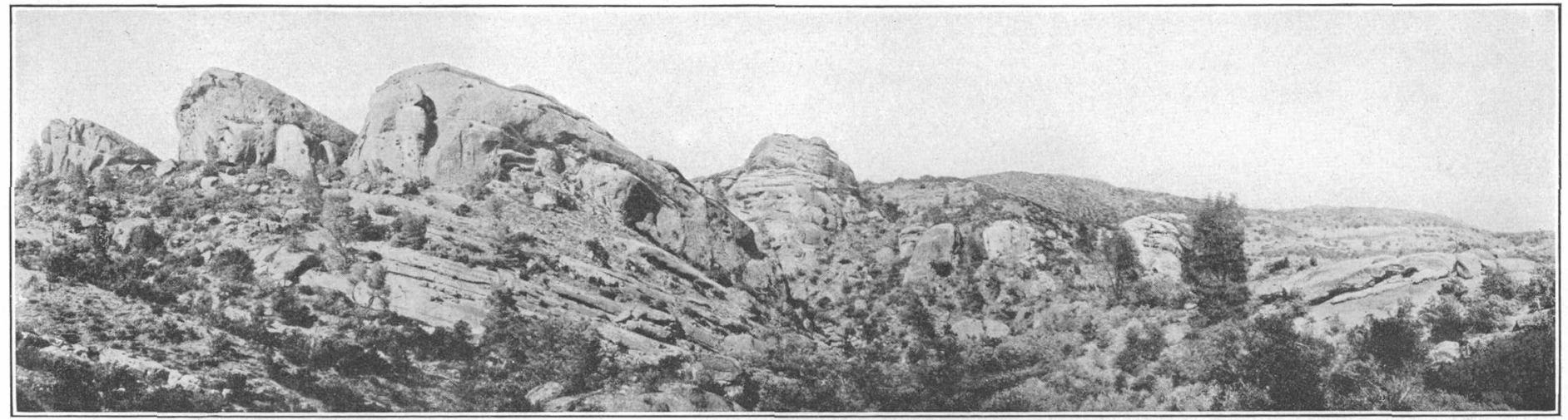

A. JOAQUIN ROCKS, FORMED BY MASSIVE SANDSTONE OF THE PANOCHE FORMATION. Looking north from point near summit of Joaquin Ridge.

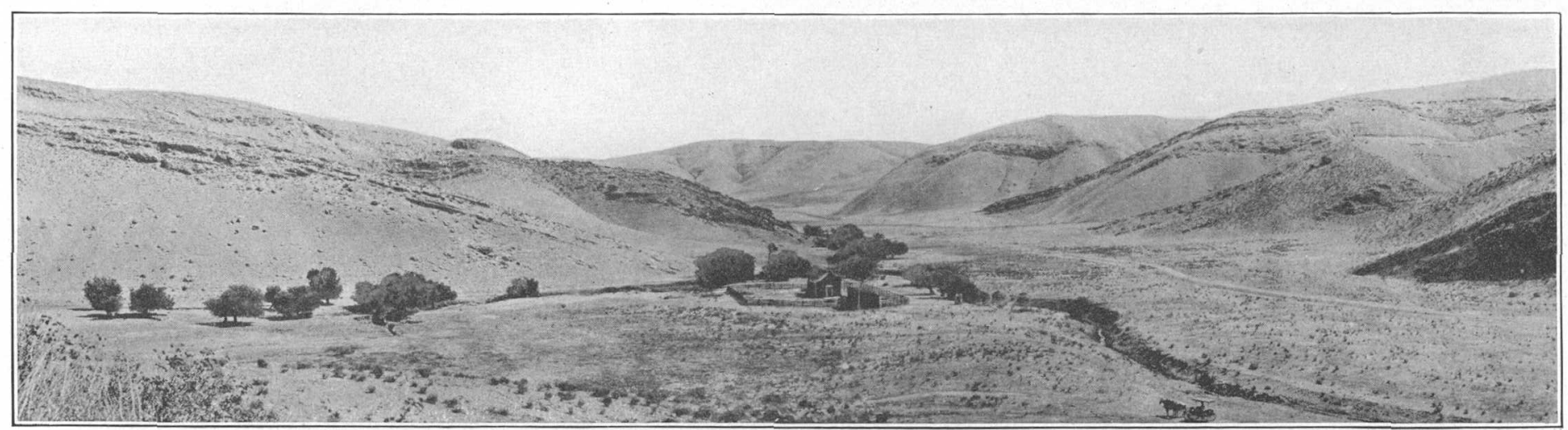

B. CHARACTERISTIC OUTCROPS OF CONGLOMERATE IN THE PANOCHE FORMATION NORTH OF PANOCHE PASS 
posed of medium to fine grained massive sandstone, blue-gray when fresh but weathering to a light tawny yellow on exposure, formed very largely of angular or subangular grains of quartz and feldspar. It contains beds of clay shale and shaly sandstone alternating with the prominent sandstone beds. In the lower part the sandstone is massive, but the alternation of zones of hard and soft strata from tens to hundreds of feet in thickness permits certain of the harder beds to weather out as thick slabs, exposing in places smooth inclined planes several hundred feet in length along the dip slope. (See Pls. II and IV, A.) These heavy slabs form the face of the picturesque castellated buttes which extend northwestward from Joaquin Ridge toward New Idria and which constitute the eastern edge of the mountainous region. Here and there the sandstone is conglomeratic, but the beds of coarse sediments are neither thick nor persistent along the strike and were apparently formed under very local conditions. They are usually only a few feet in thickness and are nowhere as thick as the similar conglomerate zones north of Panoche Pass. (See Pl. IV, B.) Reddish-brown to tawny-yellow sandstone concretions are abundant. These concretions range from nodules a few inches in diameter to spherical masses with a diameter of 8 or 10 feet. They are not, however, typical of this part of the stratigraphic column alone but appear higher in the Panoche formation as well as in the overlying Moreno formation and in the Cantua sandstone member of the Martinez (?) formation. Cavernous-weathering concretionary sandstone typical of the Panoche formation is shown in Plate XIII, $A$. On Joaquin Ridge the concretionary sandstone has a thickness of 4,400 feet. It gradually decreases in thickness toward New Idria, and at that place this member and the two overlying members, which on Joaquin Ridge have a thickness of about 900 feet, are together only 1,400 feet thick.

The strata lying between the top of the lower concretionary sandstone and the base of the Moreno formation may be divided into two parts, the lower of which is shale and the upper concretionary sandstone. This division holds good on the northeast flank of Joaquin Ridge from the head of Oil Canyon northward to and a little beyond Salt Creek, but north of that place these members are not considered as traceable. The clay shale member is characteristic of the Cretaceous deposits throughout the region and is identical in lithologic character with the lower clay shale member of the Panoche formation. The major part is formed of dark-brown to black clay shale with local beds of thin-bedded light-brown sandstone, dark-gray to black calcareous layers, and yellow calcareous nodules. This shale is best developed near Domengine Creek, where it has a thickness of 500 to 700 feet. 
The concretionary sandstone overlying this shale and between the Coalinga district and Salt Creek, forming the uppermost part of the Panoche formation, is best developed along the west side of Ragged Valley, where it forms a line of rugged hills. This sandstone is not essentially different from that forming the lower concretionary sandstone member of the Panoche formation, differing mainly in the greater size and number of the concretions which it contains. These concretions are remarkably abundant and in places seem to form over 25 per cent of the rock. In size they vary from small nodules a few inches across to spherical or irregular masses 10 or 12 feet in diameter. Near Domengine Creek this sandstone has a thickness of about 350 feet. No sharp line of division can be drawn between it and the overlying Moreno formation. At the top the sandstone is thin bedded and concretionary, grading into the arenaceous clay shale which is bedded with narrow layers of carbonaceous sandstone and which has been mapped as the base of the Moreno formation. Moreover, in this basal part of the beds mapped as Moreno there are various irregular beds of concretionary sandstone lithologically identical with the concretionary sandstone members of the Panoche formation. One such sandstone in the lower part of the beds mapped as the Moreno is traceable in irregular outcrops from Domengine Creek to Salt Creek, being separated from the upper concretionary sandstone member of the Panoche formation by about 100 feet of interbedded dark clay shale and very carbonaceous thin-bedded sandstone.

In a general way southeast of The Vallecitos the members of the Panoche formation just described may be grouped into a lower division, the lower shale member, and an upper division, including the main body of concretionary sandstone, the overlying clay shale, and the smaller body of concretionary sandstone at the top. Any separation of these beds, however, into two or four or more divisions appears to be arbitrary and applicable only to a certain area. Farther north the members grade into each other and cease to be traceable. The concretionary sandstone exposed along the axis of the Ciervo anticline in the Tumey and Griswold hills, just north of The Vallecitos, is in general equivalent to the upper part of the twofold division just mentioned. North of Panoche Creek both divisions are doubtless represented in the fairly uniform mass of alternating sandstone, shale, and conglomerate forming the Panoche Hills.

AREA NORTH OF PANOCHE CREEK.

Northward from Panoche Creek the Panoche formation comprises strata varying from coarse conglomerate containing fragments several feet in diameter through sandstone to fine compact clay shale. These beds are so intermingled and show such a gradation both vertically from one bed to another and along the strike of the same bed that it 
was not found possible to follow a single lithologic zone for any great distance. The formation includes principally arenaceous shale and thin-bedded sandstone. It contains also a few beds of hard darkbrown platy sandstone and concretion-bearing sandstone which weather out prominently from the softer beds. In general these harder and concretionary beds are far more prominent toward the top of the formation, being especially noticeable in the strata closely underlying the Moreno formation. Lenses of conglomerate locally form a large part of the section. These lentils of coarse material first appear prominently at the south in the Panoche Hills, and increasing rapidly in size northward reach their maximum development just north of Pacheco Pass. Farther north they as rapidly decline in size. The conglomerate lenses range from narrow gritty beds less than an inch thick to masses nearly 1,000 feet thick composed almost wholly of bowlders and pebbles. In some places they show a rapid gradation along the strike and vertically into the inclosing beds of finer material; in others coarse gravel and fine clay shale are perfectly bedded in alternating layers, a foot or less in thickness, indicating a rapid change in the conditions under which the various beds were formed. Along the strike the conglomerate is very irregular, lenses several hundred feet thick disappearing within a distance of a few thousand feet. The coarse beds are well developed near the schoolhouse on Ortigalito Creek. (See Pl. IV, B.)

The conglomerate is composed of poorly sorted pebbles of various porphyritic and granitic rocks, with a small amount of quartz, quartzite, sandstone, and limestone. The pebbles range from fine grains to rounded bowlders 15 or 20 inches in diameter, and there are a few fragments several feet in length, the largest seen being 12 feet long. The larger fragments are as a rule poorly rounded or more rarely angular and were probably derived from a region not far distant. The smaller ones, particularly the porphyritic rocks, are all well rounded, having usually a characteristic bun-shaped outline. The great bulk of the pebbles are of a type of rock different from those now exposed in the center of the Diablo Range, and the location of the land mass from which they were derived is problematic. Between Little Panoche and San Luis creeks a very few of the larger and less rounded fragments are somewhat similar to the various igneous rocks exposed in the upper portion of the Franciscan formation in that vicinity and may possibly have been derived from it. In general, however, the lack of pebbles plainly indicating a derivation from the Franciscan rocks is a noteworthy feature of this formation.

One of the most significant features of the conglomerate is the fact that many beds contain bowlders of sandstone and conglomerate in which trpical Chico (Upper Cretaceous) fossils occur. Such bowlders 
were found at many places and at no less than three different horizons, the lowest being in the basal conglomerate overlying the Franciscan formation northeast of Ortigalito Peak. A similar lens of conglomeratic sandstone occurs in the lower part of the Moreno formation south of Ortigalito Creek. Although the bowlders are somewhat rounded they do not show nearly so much wear as the pebbles and bowlders of the harder igneous rocks in the same beds. Evidently they have not been subjected to the abrasion incident to long transportation.

The explanation of these fossiliferous inclusions that appears most reasonable is that at various times oscillations of the shore line took place which brought littoral areas of the sediments above sea level and allowed banks to be cut in them, from which lumps of sand and gravel, somewhat consolidated by the lime of the contained shells, were washed down into the sediments that were continually being deposited near by. These beds are therefore similar to the intraformational conglomerates in the Cambrian and Ordovician of New York and Pennsylvania described by Walcott. ${ }^{1}$

Lithologically the sandstone beds do not differ radically from those forming Joaquin Ridge. They are nowhere so massive, however, and they do not on weathering give rise to the huge slablike outcrops which are so characteristic of the Panoche formation. The grains forming the sandstone are very largely angular, few being at all well rounded. Usually over 50 per cent of the grains are quartz, the rest being feldspar, white and dark mica, and a lesser number of dark minerals or rock fragments which are usually somewhat better rounded than the other grains.

In the Panoche Hills the formation has a thickness of not less than 21,000 feet. There the strata may be roughly separated into three lithologic divisions: (a) The uppermost division, immediately underlying the Moreno formation, is composed mainly of rather massive concretionary. sandstone with a minor amount of dark shale and has an aggregate thickness of not less than 4,000 feet. These beds form the rugged topography characteristic of the eastern balf of the Panoche Hills. (See Pl. XII, A.) (b) This sandstone is underlain by not less than 17,000 feet of alternating beds of dark clay shale, arenaceous shale, and concretionary sandstone, with a persistent member of interbedded coarse conglomerate and fine sandstone, 100 to 500 feet thick, at the base. This basal member contains Chico fossils, some of which appear to be in pebbles of sandstone. (c) Below the heavy conglomerate are thin-bedded carbonaceous sandstone and shale lithologically identical with those overlying the conglomerate. The thickness of these beds is unknown, inasmuch as they are exposed

1 Walcott, C. D., Palegzoic intraformational conglomerates: Geol. Soc. America Bull., vol. 5, pp. 191-198, 1893 , 
only close to the conglomerate, the contact with the Franciscan being masked by late terrace deposits, but from evidence obtained farther north it is believed that they are only a few hundred feet thick. No fossils were found in these shales, and it is possible that they represent either the Knoxville or the Horsetown formation. However, from their lithologic similarity to the overlying beds and from the fact that Chico fossils occur in the conglomerate member, contained apparently not in the matrix but in bowlders of sandstone which were evidently derived from beds of Chico age older than the conglomerate, it is thought more probable that these lower shaly sandstones are of Chico age and should also be classed with the Panoche. It is possible that the first of these three divisions may correspond roughly with the upper of the two main divisions south of The Vallecitos, and the second with the lower shale division of the south, but the lithologic features are too inconstant to warrant a definite correlation on that basis alone.

North of Little Panoche Valley the lithologic changes in the character of the beds are so numerous that it is impossible to make any lithologic divisions comparable with those in the region to the south. Between Little Panoche Valley and Pacheco Pass the Panoche formation has a thickness of not less than 20,000 feet and possibly over 25,000 feet, but as portions of the strata are covered by late terrace deposits an accurate estimate is not possible. South of Garzas Creek, where the beds are well exposed, a careful estimate places the thickness of this formation at about 20,500 feet. Northward from Puerto Creek the formation thins rapidly, apparently owing to the absence of the lower beds.

In the Tesla area certain rocks in which Lower Cretaceous fossils have been reported are grouped with the overlying Panoche formation, as the time spent in that part of the region did not permit more detailed work. However, the belt of outcrop of the Lower Cretaceous is believed to be not over a few hundred feet wide.

\section{RELATION TO PETROLEUM.}

No sign of petroleum was seen in strata of the Panoche formation, and, except possibly in the Tesla area, where petroleum has been found in beds that may be in the uppermost part of this formation, no evidence of its presence is known. The possible exception is discussed in the section on the occurrence of oil (p. 188). The source of the oil in that locality is very likely in the Moreno and not the Panoche formation. The Panoche is lower in the geologic column than any of the known oil-bearing formations of the Diablo Range or adjacent regions. It is possible that minute traces of petroleum, such as occur in many fine-grained sedimentary rocks the world over, may exist in this formation, but it is improbable that economic quantities of oil 
will be found in it. It is a significant fact that all of the shale in the formation is typical clay shale, and that none of it contains any large proportion of organic material, as do the petroliferous shale in the overlying Moreno formation and the shales in the various petroleumbearing Tertiary formations in this and in other parts of California. Except in the Tesla area wells drilled in beds of the Panoche formation have found no oil.

\section{MORENO FORMATION.}

DEFINITION.

Overlying the Panoche formation and constituting the uppermost part of the Chico group (Upper Cretaceous) is a formation composed largely of foraminiferal and diatomaceous chocolatebrown and maroon shale. This shale is at once siliceous, argillaceous, and calcareous and contains interspersed calcareous layers and concretions resembling in lithologic character and in appearance the less pure varieties of the shales of organic origin well known in various Tertiary formations of California. In a few small areas it contains pure-white diatomaceous shale like that in the Tertiary. This formation averages about 2,000 feet in thickness, and in addition to the shale of organic origin includes a great thickness of darkbrown to black clay shale containing less organic material, numerous large lenses of brownish concretionary sandstone, and locally hundreds of feet of conglomerate and fossiliferous sandstone. Numerous fossil mollusks obtained from ${ }^{\circ}$ large white limestone concretions and from the sandstone beds, as well as locally from the shale itself, establish the Upper Cretaceous age of the beds. The fossils are scattered throughout the formation from top to bottom and show that it is a unit.

The name Moreno is applied to the formation, from Moreno Gulch, on the east flank of the Panoche Hills, where it is typically exposed. Here the formation has a thickness of 1,700 to 2,000 feet and is composed predominantly of thin-bedded, rather brittle brownish and lavender-colored shales, that weather into small bits and flakes. In the lower part of the formation there are numerous beds of sandstone, locally containing poorly developed concretions and in general similar to the sandstone of the Panoche formation. The upper half of the formation is more nearly pure shale and contains a greater proportion of material of organic origin. Calcareous shale, limestone nodules, and layers of semiporcelaneous siliceous shale occur locally, and near the top of the formation there is a zone of white platy diatomaceous shale about 200 feet thick. This zone is traceable most of the way along the face of the Panoche Hills. Large sandstone dikes traversing the shale are very conspicuous, a zone of several such dikes being traceable for most of the 


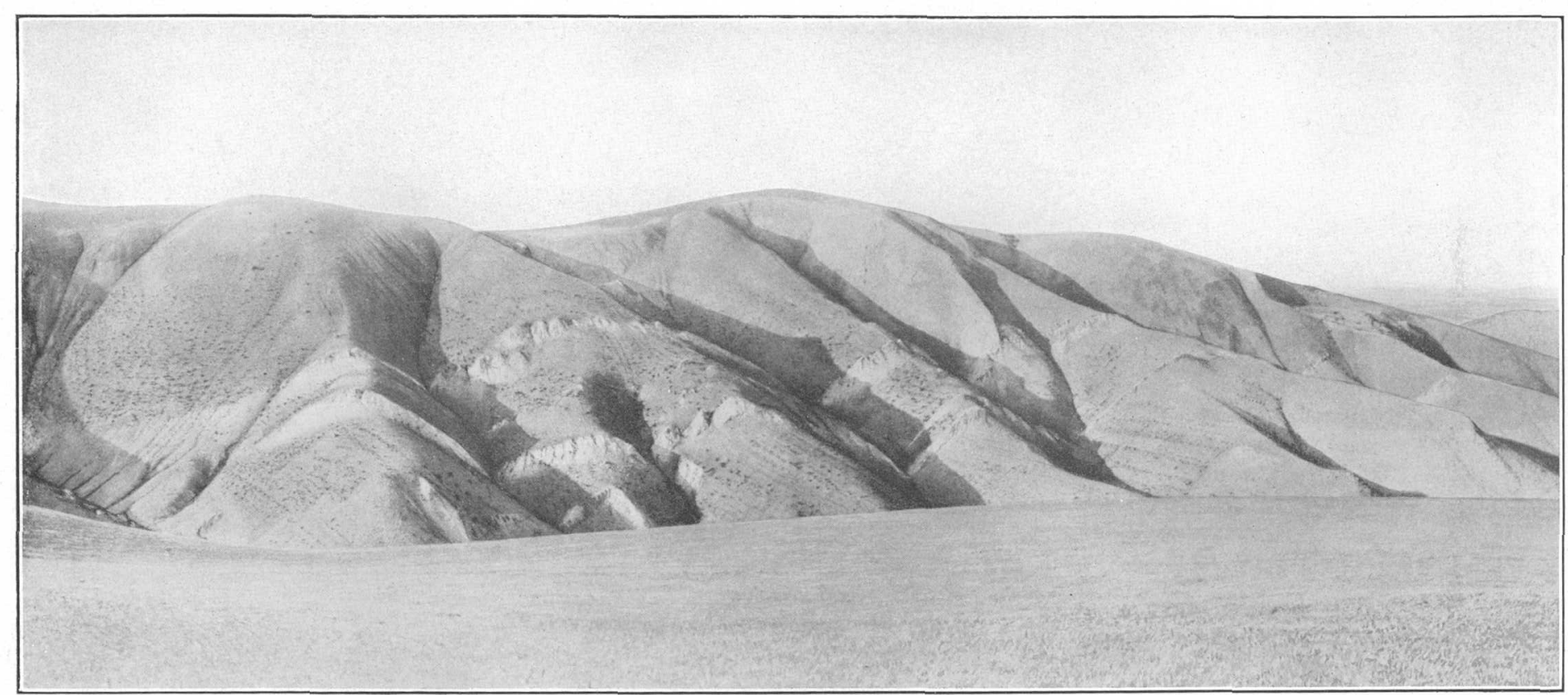

SANDSTONE DIKES IN THE MORENO FORMATION IN THE PANOCHE HILLS.

Looking north across Moreno Gulch. The lateral ridges are approximately determined by the siliceous shale. The clastic dikes are almost exactly normal to the bedding of the shale. 
distance across the strike of the formation. (See Pl. V.) Calcareous concretions are scattered through the shale, especially in the middle of the formation, but are not so numerous as they are in this formation in some other localities. Besides the foraminifers, fossil mollusks occur sparingly, among them being Hamites or Anisoceras, characteristic Cretaceous forms.

The line of separation between the Moreno and the underlying Panoche formation is somewhat arbitrarily drawn at the horizon where the sandstone beds that form the steep eastern face of the Panoche Hills dip beneath the predominantly shaly beds. The upper limit of the Moreno formation is marked by the overlying Eocene formation, which is composed of medium to fine grained grayish-white sandstone stained in irregular bands by iron oxide and weathering to a tawny-yellow color. "Moreno" is a Spanish word meaning brown and is particularly applicable to the formation because its most characteristic beds are of a chocolate-brown color.

The Moreno formation is believed to be conformable upon the underlying Panoche formation, although further evidence on this point is necessary before a positive conclusion can be reached. The relation of this formation to the Panoche has been discussed in the general description of the Chico group and of the Panoche formation. Its relation to the overlying Martinez (?) formation resembles a conformity just as much as the apparent gradation into the Panoche formation below, so far as the usual appearance of the contact goes. The paleontologic evidence, however, favors the supposition of a conformity below and an unconformity at the top. In addition to the paleontologic evidence the presence of an unconformity between the Moreno formation and the beds above is rather convincingly demonstrated by structural evidence in at least one place. This is on the north bank of Silver Creek about a third of a mile south of its junction with Panoche Creek, where a recent cutting on the county road, at its turn around the point of the hills, exposes the contact between the Moreno and Martinez (?) formations. Here the great body of dark clay of the Martinez (?) has a basal fossiliferous sandstone and conglomerate that lies with jagged contact upon the maroon shale, affording fairly clear evidence of an unconformity. The conglomerate, moreover, contains pebbles of limestone resembling the calcareous shale and limestone nodules of the Moreno.

Although the strata here described as the Moreno formation appear to bear a close relation to the older Cretaceous strata they are separated as a distinct formation because they constitute an individual and persistent lithologic division, unique among the Cretaceous beds in that they are composed largely of the remains $81281^{\circ}-$ Bull. $603-15-4$ 
of organisms such as diatoms and foraminifers, and they were evidently formed during an epoch when the physical conditions were different from those prevailing during the rest of Cretaceous time. If they do not represent an entirely separate epoch of deposition, as it is possible that they may, they at least afford a record of a marked and prolonged change of conditions. This formation acquires. a further individual importance from the fact that it forms a cartographic unit and horizon marker at the top of the Cretaceous, without which a separation between the Cretaceous and Eocene formations would be extremely difficult, and from the fact that it has a direct bearing upon the economic possibilities of the region. Although the fossils it contains show that this formation is of Upper Cretaceous age its stratigraphic equivalents in other parts of California are not known, and it is not improbable that these beds record an epoch of deposition in the Cretaceous later than any yet recognized in other parts of the State.

The discovery that the shale of the Moreno formation in places is composed largely of the remains of diatoms and in many places is indistinguishable lithologically from the Tertiary shales of organic origin is one of the most interesting results of the field work. Hitherto strata of this type have been known in California only in the Tertiary. The discovery that this shale is diatomaceous is likewise important, owing to the fact that it is one of the main oil-bearing formations of the region, thus adding one more to the list of diatomaceous shale formations that are believed to be the ultimate source of oil in California. Before its diatomaceous nature was ascertained it was believed by the writers, on the evidence of its stratigraphic relations, to be a source for part of the oil of this region. It therefore affords a good argument in support of the theory that the oils of California have a diatomaceous origin.

At the type locality and elsewhere south of Pacheco Pass a great part if not the bulk of this formation is of the organic type already mentioned, unlike any of the other Cretaceous strata, a characteristic which makes the top of the Cretaceous readily traceable throughout the southern part of the region. For a considerable distance near Pacheco Pass the Moreno formation is overlapped by younger formations. It is not possible, therefore, to trace it in continuous outcrop from one end of the region to the other. Like most of the other formations, the Moreno in the northern part of the region comprises beds somewhat different lithologically from those included in that formation in the southern part. Thus, although the beds mapped as Moreno north of Pacheco Pass are predominantly shaly and resemble in general character those in the south, they contain less organic material and approach somewhat the type of argillaceous shale so common in the Panoche formation. The beds in the north are with 
little question, however, the continuation of those mapped as the Moreno formation in the south, although conclusive proof of such continuity has not yet been obtained.

\section{PREVIOUS CORRELATION.}

Up to the time that the field work leading to this report was undertaken the beds here treated as the Moreno formation had been considered of Tertiary age by most of the geologists who had observed and mentioned them. Almost all of such observation had been restricted to the Coalinga and.Cantua regions. Watts ${ }^{1}$ termed them Eocene. Eldridge ${ }^{2}$ considered them to represent the upper portion of the Eocene, in which he included 1,000 or 2,000 feet of the underlying concretionary sandstone and associated beds of the P.anoche formation. F. M. Anderson ${ }^{3}$ believed them to be Eocene and termed them the Kreyenhagen shales, correlating them with Tertiary shale of supposed Eocene age exposed in the Kreyenhagen Hills south of Coalinga. In the preliminary report on the Coalinga district ${ }^{4}$ Ralph Arnold and Robert Anderson likewise treated this shale as Eocene, but, on the evidence obtained in the field work which forms the basis of the present report, a Cretaceous age was assigned to it both in the later report on the Coalinga district by the same authors ${ }^{5}$ and in the preliminary report on the Cantua-Panoche region ${ }^{6}$ by the senior author of the present paper. In a recent contribution J $u m b l e{ }^{7}$ reverts to the former supposition as to the age of the shale and includes it in the Eocene. Brewer, ${ }^{8}$ working in the northern part of the Diablo Range for the old California State Geological Survey, included these beds in the Cretaceous. In other parts of the State, however, members of that Survey described as Cretaceous beds which are now known to be Eocene. There is nothing in Brewer's description to indicate the formation in other parts of the State that he considered the stratigraphic equivalent of this shale in the Diablo Range. The reason that this formation has been considered Eocene and that i.t is still considered Eocene by some geologists lies in the facts that it has a much closer lithologic resemblance to the Tertiary beds than to the known Cretaceous and that it has a close association with and seems to grade into the Eocene beds that overlie it.

1 Watts, W. L., Oil and gas yielding formations of California: California State Min. Bur. Bull. 19, pp. 136,1900 .

2 Eldridge, G. H., The petroleum fields of California: U. S. Geol. Survey Bull. 213, p. 307, 1903.

a Anderson, F. M., A stratigraphic study of the Mount Diablo Range, Cal.: California Acad. Sci. Proc., 3d ser., vol. 2, No. 2, p. 163, 1905.

4 Arnold. Ralph, and Anderson, Robert, Preliminary report on the Coalinga oil district, Fresno and Kings counties, Cal.: U. S. Geol. Survey Bull. 357, p. 23, 1908.

- Arnold, Ralph, and Anderson, Robert, Geology and oil resources of the Coalinga district, Cal.: U. S. Geol. Survey Bull. 398, p. 57, 1910.

Anderson, Robert, Preliminary report on the geology and oil prospects of the Cantua-Panoche region, Dal.: U. S. Geol. Survey Bull. 431, p. 60, 1911.

7 Dumble, E. T., Tertiary deposits near Coalinga oil field and their stratigraphic relations with the Upper Cretaceous: Jour. Geology, vol. 20, No. 1, p. 30, 1912.

8 Whitney, J. D., The Monte Diablo Range: California Geol. Survey, Geology, vol. 1, pp. 39-44, 1865. 
The results of the misapprehension as to the age of this formation and some of the associated beds has been that, with the exception of the authors of. the final report on the Coalinga district (Bulletin 398) no one heretofore in discussing the relation of the Cretaceous and Tertiary in this region has had the correct line between these two great series in mind.

Inasmuch as the term Kreyenhagen shale is retained in the present report to designate Tertiary strata north of Coalinga, it is necessary to explain the relationship of the various strata to which the name Kreyenhagen has been applied. According to the original description, the Kreyenhagen shales of F. M. Anderson ${ }^{1}$ consist of "brown bituminous or carbonaceous shale, more or less sandy in the lower portion, with a maximum thickness of 600 feet as exposed on the hills a few miles north of Coalinga. Farther to the south and southeast it varies considerably, attaining at the Kreyenhagen wells a thickness of about 900 feet. *** On account of its development at the Kreyenhagen wells this member of the Eocene has been termed the Kreyenhagen shales." In the Kreyenhagen Hills the shale described by F. M. Anderson overlies sandstone that contains a Tejon (upper Eocene) fauna, whereas north of Coalinga the shale referred to by him has been found by the writers to contain Upper Cretaceous fossils. It is obviously impossible to continue the use of the term Kreyenhagen for both the Tertiary shale south of Coalinga and the Cretaceous shale north of that place, and inasnuch as the name Kreyenhagen is derived from the region south of Coalinga, it seems best to limit the name to the Tertiary shale exposed there and to the stratigraphic equivalent of that shale in other regions. The Cretaceous portion of F. M. Anderson's Kreyenhagen shales exposed north of Coalinga is here termed the Moreno formation. As here described, the Moreno formation corresponds with what was termed the purple shale of the Chico in the Coalinga report, ${ }^{2}$ and in the preliminary report on the Cantua-Panoche region. ${ }^{3}$

The term Kreyenhagen shale is used in the present report to designate a formation of probable Oligocene age comprising about 1,500 feet of diatomaceous shale which overlies the sandstone of the Tejon formation (upper Eocene) north of Coalinga, and which is believed to be the correlative of the Tertiary strata in the region south of Coalinga, described by F. M. Anderson as the Kreyenhagen shales. In the north end of the Coalinga district this Tertiary shale is separated from the Moreno formation by about 600 feet of Eocene beds, and between New Idria and Ciervo Mountain by over 5,000 feet of Eocene beds.

${ }^{2}$ California Acad. Sci. Proc., 3d ser., vol. 2, No. 2, p. 163, 1905.

2 U. S. Geol. Survey Bull. 398, pp. 57-58, 1910.

3 U. S. Geol. Survey Bull. 431, pp. 64-65, 1910. 
ITTHOLOGY AND LOCAL DEVELOPMENT.

The beds comprised in the Moreno formation south of Pacheco Pass are in many respects different from those composing it in the northern part of the region. The general lithology of the formation in the two parts of the region will therefore be described separately.

AREA SOUTH OF PACHECO PASS.

The most characteristic feature of the Moreno formation south of Pacheco Pass is the shale of organic origin. This shale is usually maroon, purplish, or chocolate-brown in color, compact, thinly laminated, brittle, siliceous, locally calcareous, and filled with impressions of Foraminifera. It weathers to platy fragments, many of which are hardly thicker than a sheet of paper, or to splinters. Interspersed through the shale are various hard calcareous layers and white oval limestone concretions of varying size, the largest at least 15 feet in length. Besides abundant foraminifers these concretions contain numerous fossil mollusks. Another peculiar feature of the shale is the presence of nodules or concretions of barite, usually from 1 to 3 inches in diameter. In some small areas they weather out abundantly from the shale.

The more siliceous facies of the shale bears a considerable resemblance to the diatomaceous Kreyenhagen shale (Oligocene?) overlying the Tejon formation (upper Eocene) in this region, and to the brownish argillaceous facies of the middle Miocene shale of the Monterey group, which in other parts of the State overlies the Vaqueros formation. The similarity to these formations is especially marked in a considerable area between Little Panoche and Ortigalito creeks, where the shale is earthy and massive and weathers pure white. The lithologic character of the shale here is identical with that of the pure diatomaceous material occurring in the Kreyenhagen shale, and well known in the shale of the Monterey group and other Tertiary formations along the Coast Ranges. A body of similar white diatomaceous shale occurs all along the east flank of the Panoche Hills in the upper portion of the formation. In the field, before the shale was examined microscopically, the presence of diatoms was strongly suspected. This idea proved to be correct, for under the microscope traces of these minute organisms are seen to be abundant, and in the soft white shale between Little Panoche and Ortigalito creeks they are fully as plentiful as they are in the Tertiary shale. Diatoms were also seen in the more compact and thinly laminated shale, although their remains are not so easily recognized as they are in the softer beds. It is believed that the more compact shale as well as the soft facies is formed in considerable part of the remains of diatoms, but that in the greater lithification which these beds have 
undergone recognizable trace of most of these organisms has been destroyed. The same difficulty is encountered in recognizing diatoms in the more indurated facies of the Tertiary shale.

The maroon shale of organic origin is best developed in the upper half of the formation. Together with the interstratified dark clay shale, it forms a well-marked belt of low topographic relief, characterized by small rounded knolls which are covered by platy fragments of the siliceous shale and which are almost barren of any vegetation other than a few junipers and scrub oaks. These bare purplish slopes, dotted by the dark-green trees, form a very striking feature in the otherwise almost treeless foothills.

Interstratified with the siliceous shale, and especially prominent in the lower part of the Moreno formation, are beds and lenses of dark clay shale not different from that common in the Panoche formation or from that in the overlying Martinez(?) formation. In some places this shale is thinly interbedded with fine-grained light-gray sandstone; in others it forms masses many feet in thickness that show almost no trace of bedding.

Sandstone is present in the Moreno formation throughout the region, but the proportion of it varies greatly. In some places the sandstone occurs in beds from less than an inch to a few inches in thickness, interstratified in alternating layers with clay shale; in other places it occurs as lenticular masses, attaining several hundred feet in thickness, almost free from shale. The thin-bedded sandstones are usually very micaceous and contain considerable carbonaceous matter. In places the sand is almost pure white, though stained reddish brown by iron along irregular lines and having fracture surfaces coated with ocher. Locally, as along the upper course of Cantua Creek, such whitish sandstone alternating with the maroon or chocolate-brown shale forms almost a counterpart of the white sandstone and carbonaceous shale in the Tejon formation, and when first seen the beds were mistaken for that formation. The thicker masses of sandstone are usually not continuous, but are really huge lenses included in the predominantly fine-grained beds. They are formed of massive concretionary sandstone, gray when fresh but weathering tawny brown, and identically the same as that which forms so large a part of the Panoche formation below and of the Cantua sandstone member of the Martinez (?) formation above. The sandstone weathers to ragged hills, which are exceptionally prominent in the belt of generally smooth topography formed by the shale. Sandstone is most prominent in the lower part of the formation, where throughout the region it apparently forms a perfect gradation into the underlying sandy beds of the Panoche formation.

The shale is cut.by numerous sandstone dikes lithologically similar to the sandstone interstratified with the shale, except that they 
usually contain somewhat more mica. These dikes are well shown in Plate V. They traverse the shale in almost every direction, with dips varying from almost horizontal to practically vertical. Clastic dikes are a common feature of shale of this type throughout California and are especially prominent in the Kreyenhagen (Oligocene?) shale in this region. (See Pl. VIII, p. 74.)

A peculiar lens of coarse material varying in thickness from 50 to over 400 feet is locally developed between Little Panoche and Ortigalito creeks at 500 to 800 feet above the base of the Moreno formation. The beds in this lens are composed of fragments which range from fine-grained sand to poorly rounded pebbles 10 or 12 inches in diameter. Most of the larger fragments are formed of fossiliferous Cretaceous sandstone, the fossil mollusks in the fragments being of similar types to those contained in the sandstone closely underlying the Moreno formation. The presence of this lens of coarse material in and apparently perfectly bedded with shale of organic origin is peculiar, and doubly so when it is seen that the land mass from which a large part of the detritus was derived was formed of Upper Cretaceous formations. The lens is analogous to the conglomerate lenses in the Panoche formation, which contain fossiliferous Cretaceous sandstone bowlders. (See p. 44.) These coarse beds are not very extensive, grading along the strike in a distance of a few miles through a coarse grit to fine shaly sand. Where the lens is composed of fine material it contains fossils, similar to those found in the bowlders, in positions such that they can not be considered as foreign to the beds and must represent the life in this region at the time the sediments were being deposited.

South of Pacheco Pass the Moreno formation is exposed in three detached areas. One extends from a point a little north of Los Gatos Creek, in the Coalinga district, northwestward to and beyond New Idria; another lies along the south flank of the Griswold and Tumey hills from a point west of Griswold Canyon nearly to Ciervo Mountain, where it swings around the end of the plunging Ciervo anticline and continues northward through the foothills nearly to Los Banos Creek; the third is in the faulted region on the north side of Panoche Valley near Llanada.

From the vicinity of Oil City, at the south end of the area mapped, northwestward to a point just south of Salt Creek the Moreno formation has an average thickness of about 1,600 feet and is overlain by dark clay shale of the Martinez (?) formation. South of the area shown on the map the Moreno formation and also the overlying Martinez (?) formation gradually wedge out, and near Los Gatos Creek Tejon (upper Eocene) rocks rest directly upon the sandstone of the Panoche formation. It is not known whether the disappearance of the Martinez (?) and Moreno formations is due to their erosion 
prior to the deposition of the Tejon or to the fact that they were never deposited there. Northwestward from Salt Creek the Moreno formation maintains an approximately constant thickness nearly to the San Carlos Bolsa, about 3 miles southeast of New Idria, beyond which the thickness decreases somewhat and the beds partake more of the character of clay shale.

The Moreno formation exposed along the north side of The Vallecitos varies greatly in thickness. This variation is due in part to the unconformable overlapping of the younger formations and the consequent concealing of the upper portion of the Moreno, but also in part to the fact that the change from the deposition of sand to that of shale did not take place simultaneously throughout the region. In consequence, the beds mapped as the lower portion of the Moreno in one part of the region are the time equivalent of those in the upper portion of the Panoche in another part. Near Griswold Canyon, where the Union Oil Co.'s wells were drilled, the thickness of the shale exposed is not less than 1,000 feet and is probably considerably greater, whereas about 4 miles east of that place the formation is overlapped completely by the Vaqueros formation. On the northeast flank of the Ciervo anticline and northward along the foothills to Ortigalito Creek the Moreno formation maintains a fairly constant thickness between 2,000 and 3,000 feet. As far north as Little Panoche Creek it contains relatively little sand and is formed largely of the typical shale of organic origin. Farther north the formation becomes gradually more sandy. Between Little Panoche and Ortigalito creeks are two notable zones of coarse material. The lower one of these, which has already been mentioned, is a zone of coarse gravel occurring between 500 and 800 feet above the base of the formation and the upper one is a zone of fine-grained fossiliferous sandstone varying from about 300 to nearly 1,000 feet in thickness, which is separated from the overlying Martinez (?) formation by 100 to 200 feet of thin-bedded purplish shale of organic origin.

The small area of the Moreno formation exposed on the north slope of Cerro Bonito Ridge, about $2 \frac{1}{2}$ miles southeast of Llanada, is formed largely of the thin-bedded platy-weathering shale of organic origin, which is so typical of the formation in the Cantua region. It is overlapped on both the east and the west by Miocene formations, but it may and probably does continue farther to the east beneath a portion of the western half of Panoche Valley under the cover formed by these later beds. The thickness of the Moreno formation exposed here is not less than 800 feet.

AREA NORTH OF PACHECO PASS.

North of Pacheco Pass the Moreno formation is exposed in two areas-one extending from a point near San Luis Creek nearly to 
Corral Hollow Creek, the other from the south side of Corral Hollow Creek near Tesla to the east edge of Livermore Valley. The beds exposed in the first-mentioned area, along the edge of the San Joaquin Valley, are divisible into two parts, the lower one composed mainly of shale and the upper one of sandstone. The sandstone has a rather local development.

Lower shale.-Lithologically the shale north of Pacheco Pass differs somewhat from the typical shale of the Moreno farther south. It is composed mainly of dark-brown or black clay shale, which when fresh and damp has a conchoidal fracture, but on weathering assumes a maroon or lavender color and develops a platy fracture, causing outcrops to weather rapidly and form loose slopes of shale flakes. Through the northern part of the district the shale is sandy toward the base, showing a perfect gradation into the underlying Panoche formation from typical clay shale to sandy shale, and finally to concretionary sandstone. Although at several places the shale appears to be largely of organic origin, this member north of Pacheco Pass is predominantly a carbonaceous clay shale as distinguished from the typical shale of the Moreno in the southern part of the region. Various beds of concretionary sandstone that are especially prominent from a point a little north of Big Salado. Creek to Curran Creek are interstratified with the shale. Just north of Puerto Creek the Moreno formation is exposed in a zone a little over 1 mile in width, the shaly portion being in three parts, separated from one another by massive concretionary sandstones. The sandstone divisions are about equal in width to those of shale and form prominent ridges.

Between Quinto and Puerto creeks the lower division of the Moreno formation varies in thickness from about 1,800 to 3,000 feet, the average being about 2,500 feet. Of this some 40 to 50 per cent is sandstone. On Hospital Creek the Moreno formation has an exposed thickness of 1,950 feet, but it is overlain by late Tertiary beds, and the full thickness is probably not shown. The strata here are mainly shale and are probably comparable with the lower shaly portion of the formation south of Puerto Creek.

The Moreno formation as mapped in the area extending from the vicinity of Carnegie to Livermore Valley is formed largely of shale, part of which has a somewhat purplish color and weathers to platy outcrops similar to those of the siliceous shale farther south. Much of it, however, is a dense black clay shale. The dark shale contains much carbonaceous matter which has in places led to its being prospected for coal. The formation is from 200 or 300 feet to about 1,000 feet thick. The variation in thickness is due, in part at least, to the unconformable relation between the Moreno and the overlying 'Tejon formation (upper Eocene). In parts of the region, however, sandy beds like those constituting the Panoche formation con- 
tinued to be formed long after the beginning of the deposition of fine clays in regions near by. As in the mapping the sandy beds have been grouped with the Panoche and the shaly beds with the Moreno, the thicknesses of the two formations vary considerably.

Upper sandstone.-From Quinto Creek northward for about 20 miles to and a little beyond Salado Creek the upper part of the Moreno formation consists of fine-grained micaceous gray sandstone and concretionary or platy sandstone, in which occur several zones of fine pebbles. The sandstone beds overlying the lower shaly portion of the formation outcrop in a rather prominent line of hills separating the zone of low country formed by the underlying shale on the west from the terraced hills formed by the Tertiary beds on the east. Between Quinto and Garzas creeks occurs a gray sandstone with numerous layers of conglomerate, in which most of the pebbles are small but which contains a few rounded fragments 7 to 10 inches in diameter. Fossil mollusks are present through almost the entire zone and in places are so plentiful that the rock is virtually an impure limestone. Concretionary sandstone is almost if not entirely lacking. North of Garzas Creek; the sandstone is less conglomeratic and large brownish sandstone concretions are prominent in the lower part. On Orestimba Creek the sandstone is about 1,150 feet and near Salado Creek almost 1,450 feet thick. Near Puerto Creek it becomes gradually more shaly, assumes a purplish color, and can not be differentiated from the underlying shaly member of the Moreno formation.

The change from the deposition of clayey sediments to that of sandy sediments was not abrupt, and the line of division between the lower and upper members of the Moreno formation is rather indefinite. Moreover, the character of the sediments was evidently governed by local conditions, which resulted in the deposition of sands and clays at the same time in near-by areas. Thus the two members of the formation vary considerably in thickness from place to place. The plane of separation between these beds and the overlying Eocene is almost equally indefinite. The similarity in lithology of the upper fossiliferous member of the Moreno formation (Upper Cretaceous) to the overlying fossiliferous Tejon (upper Eocene) and the seeming conformity in the attitude of the two formations would lead one to believe that they are actually conformable. The absence of any strata which might be considered the equivalent of the Martinez formation (lower Eocene) is, however, sufficient evidence that there must be in this section a plane of nonconformity and that sedimentation was not continuous from Cretaceous into Tertiary time. 


\section{RELATION TO PETROLEUM.}

The Moreno formation is one of the most important formations of this region in connection with the occurrence of petroleum. It is believed to be at once the original source and the present reservoir of much of the oil. The light-gravity oil obtained by the wells in the old Oil City field, at the north end of the Coalinga district, is found in this formation. The same is true of such petroleum as has been found in the canyon north of The Vallecitos, where the Union wells were drilled. At both these localities shale of the Moreno formation is saturated with petroleum, and several seeps of light-gravity oil occur. At many other places south of Pacheco Pass the shale and intercalated sandy beds once contained or still contain petroleum. North of Pacheco Pass the evidence that these beds contain, or have contained, oil is not so good as it is in the southern part of the region. It is believed very likely that the oil exuding from beds of Miocene age on the Hamilton ranch, east of Livermore, had its origin in this formation, although various elements of doubt enter into this supposition, as will be explained later.

There is little question that this formation at one time contained large amounts of petroleum in places where no signs of it remain, and it evidently still contains oil in localities where the structural and other conditions are favorable. It is the oidest part of the geologic column that is known to be oil bearing in this region. Its diatomaceous and foraminiferal shale was very probably the original source of the oil associated with it. In other parts of the southern half of California accumulations of petroleum are closely associated with beds formed largely of diatomaceous and foraminiferal shale of Tertiary age, and it is from these Tertiary shales that the oil is believed to have been derived in all the other fields. One of the strongest proofs which could be offered in support of the theory that shale of organic origin is the ultimate source of oil in the California fields is the fact that along portions of the east flank of the Diablo Range occurs an oil-producing formation which lies at a lower horizon than that of any other productive sedimentary formation in the southern half of the State and which is associated with the only strata formed mainly of diatomaceous and foraminiferal shale that are known to occur below the Tertiary in the southern half of the State. Although the age of a bed does not appear to be of any particular value in determining whether or not oil may form in that bed, it is worthy of note that the oil in the Moreno formation is of different character from that which appears to have been derived from the Tertiary shale, the Moreno oil containing paraffin wax and a low percentage of asphalt, whereas the Tertiary oils are typical asphalt oils; moreover, oil found in small quantity in presumably Cretaceous formations in other places on the Pacific coast is said to be of somewhat similar composition to the oil in the Cretaceous formation here 


\section{TERTIARY SYSTEM.}

EOCENE SERIES.

\section{SUBDIVISIONS.}

The Eocene series overlying the Moreno formation is here divided into two main parts; the lower of which is termed the Martinez (?) formation (lower Eocene), and the upper is correlated on good paleontologic evidence with the Tejon formation (upper Eocene). The division tentatively referred to the Martinez formation is recognized only in the district lying south of Pacheco Pass, whereas the Tejon is practically continuous from one end of the region to the other. Where the Tejon is not exposed, between Ortigalito and Quinto creeks and between Puerto and Corral Hollow creeks, it is probably continuous between the younger formations.

\section{MARTINEZ (?) FORMATION.}

GENERAL FEATURES.

The lower Eocene strata here mapped as the Martinez (?) formation are of marine origin and are composed mainly of massive fine to medium grained, locally pebbly arkose sandstone containing large brown sandstone concretions, dark clay shale, and shaly sandstone. These beds, of distinctly detrital origin, rest unconformably in at least a part of the region, upon the shale of organic origin that composes the Moreno formation (Upper Cretaceous) and are overlain unconformably by beds that contain a marine invertebrate fauna characteristic of the Tejon formation (upper Eocene).

In the region under discussion the Martinez (?) is exposed in two areas and possibly in a third small intermediate one. One area extends from the south end of the region northward to and about 2 miles beyond Panoche Creek and westward for an undetermined distance on both the north and the south sides of The Vallecitos. Another is in the outer foothills between Little Panoche and Ortigalito creeks. The small intermediate area in which the Martinez (?) is probably exposed, but in which its presence has not yet been definitely proved, is on the northeast flank of the Panoche Hills.

The lithology and thickness of the Martinez (?) vary considerably in the different parts of the region. In the southern area it has a maximum thickness of over 5,000 feet and is formed of beds of massive very concretionary gray sandstone, and dark clay shale which look very much like portions of the Panoche formation. North of Little Panoche Creek it has a maximum thickness of about 1,100 feet and is a fairly uniform body of very fine grained massive gray sandstone which contains fewer and less perfectly formed concretions than the Martinez (?) in the southern area and little if any interstratified dark 
clay shale. In the northern area the formation is fairly homogeneous throughout, and contains no well-defined lithologic members. In much of the region south of Panoche Creek it can be separated on a purely lithologic basis into two parts, one composed predominantly of - tawny-weathering massive concretionary sandstone with some interstratified clay shale, the other largely of dark clay or clay shale with relatively little interbedded sandstone. The part consisting mainly of sandstone will be referred to as the Cantua sandstone member, from the fact that it reaches its greatest development at the head of the western branches of Cantua Creek. These members are rather distinct cartographic units, but they do not represent definite time units. Where both members are present the Cantua sandstone occupies the lower part of the formation, but it appears to be in the nature of a giant lens of sandstone included in the finer material and grading laterally into it. Where the Cantua sandstone is absent and the clay shale makes up the whole formation the sandstone is believed to be represented by the fine-grained beds. This relationship will be brought out more clearly in the following discussion of the areal distribution of the beds and the problems presented by them.

\section{AREA SOUTH OF PANOCHE CREEK.}

DISTRIBUTION AND CORRELATION.

The Martinez (?) formation first appears near the south end of the region shown on the map as a thin body of clay shale between the Moreno formation (Upper Cretaceous) and the Tejon formation (upper Eocene). From this place northward it gradually increases in thickness, reaching about 750 feet near Salt Creek. To this place the formation is composed almost wholly of dark clay shale. About a mile south of Salt Creek a thin wedge of sandstone, the Cantua sandstone member, makes its appearance between the shale and the underlying Moreno. This sandstone grows rapidly thicker toward the west, until along upper Cantua Creek, within a distance of less than 12 miles, it has attained a thickness of about 4,500 feet. Its lithologic character is almost identical with that of the concretionary sandstone of the Panoche formation (Upper Cretaceous). The belt of outcrop formed by the overlying shale continues uninterruptedly westward, retaining a width and stratigraphic thickness in a general way similar to that which it has near the south end of the sandstone lens. North of New Idria the sandstone member becomes thinner within a short distance and finally disappears on the north flank of the Ciervo anticline, beyond which the shale continues to the Panoche - Hills with a thickness not very different from that which it has all the way from the south end of the region.

When the first field work was done in this region by the writers, this dark shale and the underlying sandstone were believed to be 
different formations, the shale being considered Eocene and the sandstone Cretaceous. On the basis of lithologic resemblances and the areal distribution of the beds this seemed at first sight the natural classification. The clay shale has the appearance of a constant stratigraphic formation and of overlapping the sandstone unconformably. Furthermore, fragments of fossils found by the writers in the sandstone were at first taken to be Ammonites; and Messrs. F. M. Anderson and G. C. Gester ${ }^{1}$ reported the discovery in these beds, along the east fork of San Carlos Creek about $2 \frac{1}{2}$ miles northeast of New Idria, of a large fossil, which they identified as an ammonite. The occurrence of these fossils, of a genus that is generally believed to have died out previous to Tertiary time, was thought to bear out the supposition of the Cretaceous age of these beds. For these reasons the beds here mapped as Martinez (?) were separated into two parts in the preliminary report on the Cantua-Panoche region, the sandstone being called Cretaceous and the shale Eocene. Later work, especially an examination of the paleontologic material, has led to the following conclusions:

1. The sandstone, even in its thickest part, is all of Eocene age. Its age at Salt Creek, near the first outcrop of the member on the south, is proved by the presence in the basal beds of a glauconitic sand rich in Eocene fossils. At this place the Cantua sandstone is nearly 700 feet thick, and the entire thickness of the Martinez (?) is about 1,450 feet. The continuity of the basal bed westward from Salt Creek seems certain, although at first it was believed to be open to question. One reason leading to the belief that the basal bed follows a constant horizon is that a similar glauconitic sand containing fossils (most of which, however, are indeterminate) occurs at the base of the Cantua sandstone 9 miles to the west, where that member reaches its maximum thickness of about 4,500 feet. The fragmental fossils which were collected by the writers and which in the field were believed to be Ammonites proved on closer study to be Aturia,' a genus not uncommon in the Eocene. This suggests that the fossil found by F. M. Anderson and G. C. Gester, as above mentioned, may also be an Aturia. If it should prove to be an Ammonite, it would be extremely interesting as the first instance noted of the occurrence of fossils of this type in the same formation with fossils which are considered typical of the Eocene.

2. The clay shale does not represent a constant stratigraphic unit, but where it rests directly upon the Moreno its basal beds probably represent the same horizon as the basal zone of the Cantua sandstone. This is indicated by the presence of a layer of glauconitic sand in the basal part of the clay shale just north of the Oil City 


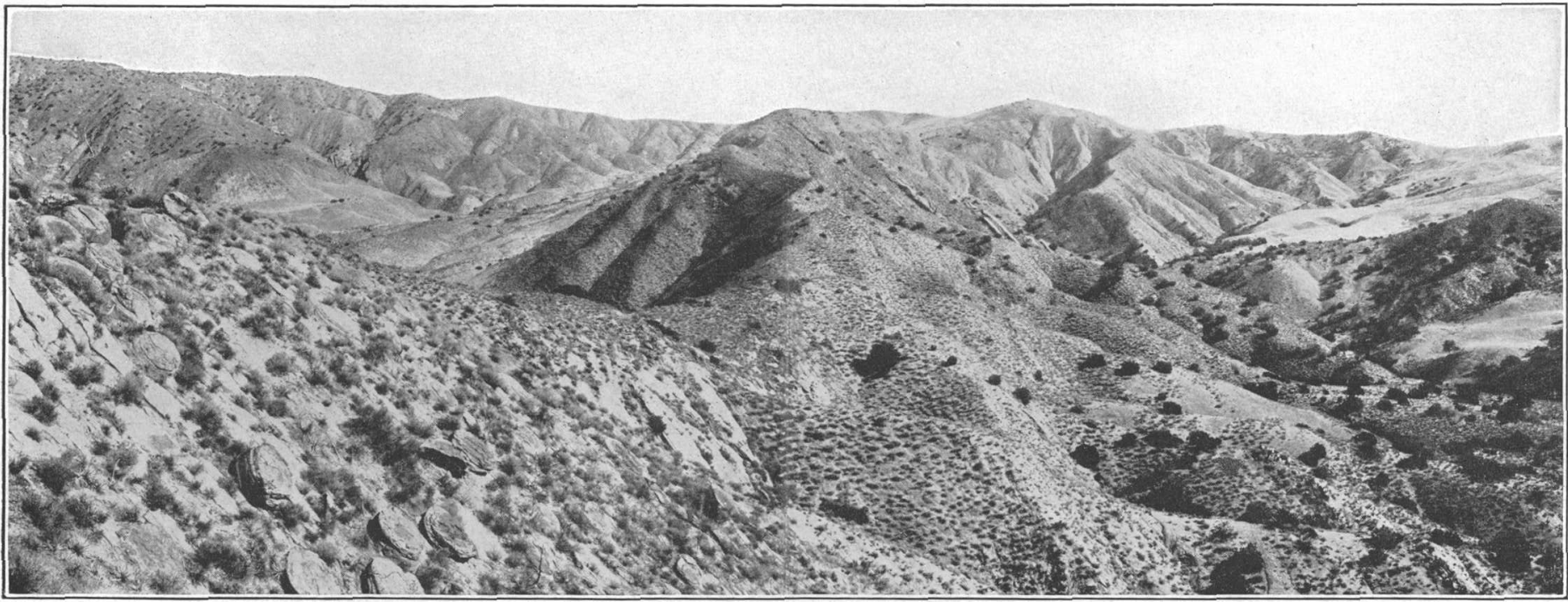

WEST END OF GRISWOLD HILLS, FORMED BY SOUTHWARD-DIPPING CRETACEOUS AND TERTIARY STRATA.

The ridge in the center is formed of concretionary sandstone of the Martinez (?) formation. The valley to the left is excavated in the Moreno formation. It is here that the wells of the Union Oil Co. were drilled. The high hills to the extreme left are formed by the Panoche formation; the low topography to the right by the Tejon formation and Kreyenhagen shale. 
camp, containing the same fauna as that found on Salt Creek at the base of the Cantua sandstone.

3. The sandstone and shale are consequently in reality different facies of the same formation, the sandstone grading laterally into the shale.

4. The thinning and final disappearance of the formation both north and south of the Cantua-New Idria area is due in part to the progressive elimination of more and more beds from the top, owing to the unconformable overlap of the Tejon formation. It is noteworthy, however, that along the main eastern belt occupied by the outcrop of these beds the proportion composed of fine-grained material steadily increases in both directions as the total thickness decreases. This fact may indicate that the decrease in thickness is not entirely due to the overlapping of the Tejon upon the upper beds, but that the Cantua sandstone was formed in a rapidly filling basin, while the deposition of the finer-grained beds went on more slowly. This hypothesis is further supported by the occurrence through much of the region of a fairly continuous fauna in the upper beds exposed. These fossils are, however, not limited to a narrow zone, but range through several hundred feet of strata. They can not therefore be regarded as marking so definite a horizon as the peculiar thin fossiliferous glauconitic sandstone beds at the base of the Martinez (?).

CANTUA SANDSTONE MEMBER.

The outcrop of the Cantua sandstone member of the Martinez (?) formation occurs in two areas, one extending from a locality near Salt Creek northwestward to and beyond New Idria, the other on the north side of The Vallecitos extending from the vicinity of the axis of the Ciervo anticline westward for an undetermined distance beyond Griswold Canyon. South of Salt Creek and north of the axis of the Ciervo anticline this sandstone grades laterally into fine clay shale. The member consists mainly of massive medium to fine grained gray sandstone weathering to tawny yellow, composed largely of grains of quartz and feldspar with fewer fragments of other rocks, and containing numerous hard, regularly formed sandstone concretions. Concretionary sandstone, believed to be Martinez (?) at the west end of The Vallecitos is shown in Plate VI. Interbedded with the sandstone are many beds of dark clay shale which locally attain thicknesses of several hundred feet. The member as a whole is almost an exact replica of the concretionary sandstone of the Panoche formation, and until the stratigraphic value of the Moreno formation was appreciated, the Cantua sandstone was mistaken in the region near New Idria for part of the Panoche formation.

From Salt Creek nearly to the head of the west forks of Cantua Creek the basal parts, about 100 feet thick, resting upon the shale 
of the Moreno formation is formed of dark-brown to black clay shale. and sandy clay, locally glauconitic. As already pointed out, these basal beds continue to the south of Salt Creek, forming the lower part of the uniform body of clay shale that rests upon the Moreno formation at the south end of the region. The basal shale resembles rather closely portions of the underlying Moreno formation, and were it not for the fact that it contains typical Tertiary fossils it would seem to belong with the underlying Cretaceous shale rather than with the overlying sandy Eocene strata. The fossiliferous glauconitic sandstone of Salt Creek already mentioned occurs in this basal shale. The presence of such a shale below the sandstone serves to emphasize the lenticular nature of the sandstone mass as a great inclusion within a body of finer material. Another such shale occurs in the lower middle part of the member and acquires a thickness of many hundreds of feet in places between Cantua Creek and New Idria. It divides the sandstone beds roughly into lower and upper zones, but such zones are not traceable, for lenses of concretionary sandstone are scattered through the shale, and fine-grained shaly beds alternate with the sandstone, especially in the upper portion of the member.

\section{CLAY SHALE.}

The clayey beds which overlie the Cantua sandstone member and which locally form the whole of the Martinez (?) formation consist mainly of dark clay shale, almost black when fresh, but weathering iron-gray or yellowish gray. They are not adequately described by either the designation clay or shale, being compacted, though little indurated beds of silt with some fine sand intermingled. They are soft and weather easily yet at the same time are tough and difficult to fracture. In some places they are so compact that they show almost no trace of stratification; in others they have a distinct shaly lamination. The term "siltstone," if it were in use, would most nearly describe this rock. For the lack of a better word the term shale is used for these beds and for material of a similar character in several other formations in this region. Intercalated with the clayey beds are lenses and beds of fine-grained and, in some places, concretionary sandstone. These occur especially toward the lower part of the shale in areas where it overlies the Cantua sandstone member and form a gradation to the more predominantly sandstone beds below, the line of separation between the Cantua sandstone and the shaly beds being entirely arbitrary. Besides these larger sandy zones there are many small lenses or stringers, from a fraction of an inch to a few feet in thickness, of yellow or gray sand and of fine, rather angular white sand. The latter is similar to the white sand of the overlying Tejon formation in this same region and, like that sand, is formed 
largely of quartz grains. Similar lenses of green glauconitic sand occur near the base of the formation, as already noted.

Such clay shale beds as these compose the whole of the Martinez (?) formation and overlie the Moreno formation with probable unconformity in the area south of Salt Creek and also in an area extending from the vicinity of the divide between Tumey Gulch and Panoche Creek to and about 2 miles north of Panoche Creek. Elsewhere south of Panoche Creek, except on the south side of The Vallecitos and near Griswold Canyon, the shale forms the uppermost exposed portion of the Martinez (?) formation, conformably overlying the Cantua sandstone member.

The thickness of the predominantly shaly part of the formation as mapped varies considerably, ranging from about 400 feet at the head of Oil Canyon, on the south, to a maximum of a little over 1,100 feet at Panoche Creek, on the north. South of the former point and north of the latter it wedges out beneath the Tejon. About 4 miles east of New Idria, where the Cantua sandstone member is best developed, the clay shale overlying it is at least 500 feet thick, giving a total thickness of at least 5,000 feet for the Martinez (?) formation as a whole.

AREA NORTH OF PANOCHE CREEK.

Between Little Panoche and Ortigalito creeks the Martinez (?) formation is fairly uniform in character throughout. It comprises about 1,1.00 feet of beds, mainly fine-grained massive gray arkose sandstone, locally very micaceous and in places containing abundant gypsum. Interspersed through these beds are numerous darkbrown concretions 2 or 3 feet in diameter, somewhat similar to the concretions characteristic of the Cantua sandstone to the south, though they are usually less hard and less regularly formed and many of them are filled and coated with a crystalline mass of gypsum. Fossils are abundant at several horizons, the lowest being that represented by the bed that is mapped as the base of the formation. The fossiliferous beds are usually somewhat calcareous and, as they weather a little less easily than the rest of the formation, they determine long, low ridges that extend parallel to the edge of the San Joaquin Valley.

The Martinez (?) formation here rests directly upon the shale of organic origin in the Moreno formation and is overlain by the gritty and pebbly white sandstone of the Tejon. The uppermost part of the Moreno is composed of shale of organic origin which seems to grade gradually into the overlying Martinez (?). This seeming gradation, combined with the fact that the hills here are low and weather easily, makes it difficult to place the contact definitely. Thus, although the typical shale of organic origin in the Moreno and the $81281^{\circ}-$ Bull. $603-15-5$ 
fossiliferous sandstone of the Martinez (?) are exposed within 100 feet stratigraphically, the intervening strata might belong equally well with either the overlying or the underlying formation. The same indefiniteness exists as to the exact position of the top of the Martinez (?). The uppermost beds of the formation as mapped are the highest beds which contain numerous brownish sandstone concretions, the nonconcretionary, coarse, gritty white sands between them and the diatomaceous Kreyenhagen shale being considered as Tejon. No fossils were found in the uppermost 200 feet or so of the beds mapped as Martinez (?), and it is possible, though not believed probable, that this portion should be grouped with the Tejon.

The Martinez (?) formation on the southeast flank of the Panoche Hills consists mainly of dark clay shale, with a little intercalated finegrained sand. This material forms the north end of the belt of outcrop of Martinez (?) that extends unbroken from the south end of the region shown on the map. All the Eocene beds along the northeast flank of the Panoche Hills are tentatively mapped as Tejon, but it is probable that the Martinez (?) is represented by their lower portion on the northeast flank of the hills, a few miles south of Little Panoche Creek. The Eocene beds there consist of fine gray sandstone and have a maximum exposed thickness of about 1,000 feet. The upper few hundred feet is certainly Tejon, as indicated by the fossils it contains, but the time spent in this area did not permit a determination of the age of the beds below the fossiliferous horizon.

\section{STRATIGRAPHIC RELATIONS.}

It may be stated with fair assurance that the Martinez (?) rests unconformably upon the Moreno formation and that the Cretaceous and Tertiary periods were separated by an epoch of movement and erosion. At one point on Silver Creek, mentioned in the description of the Moreno formation, there is evidence of interrupted sedimentation in the form of an erosional surface between the two formations. Aside from this, convincing structural evidence of an unconformable relation was found very difficult to obtain, and prior to this discovery the writers had assumed the presence of an unconformity, largely on the strength of the paleontologic evidence and in spite of widespread lithologic indications to the contrary. The main reasons for believing that an unconformity has been proved to exist here are as follows: (a) The difference in the faunas of the two formations, so far as these faunas are definitely known, is so great as to indicate a considerable lapse of time or the intervention of some very pronounced change of conditions. The fauna of the Moreno is characteristic of what is usually considered Upper Cretaceous and that of the Martinez (?) is of an Eocene type. (b) The thickness of the Moreno formation on the north side of The Vallecitos is locally much 
reduced, apparently in part at least by the overlapping of the Martinez (?) beds. (c) An erosional unconformity and basal conglomerate in the Martinez (?) is exposed on Panoche Creek. (d) The fossiliferous and locally pebbly lenses of sandstone and sandy clay in the basal Martinez (?) close to the contact with the underlying Moreno formation contain pebble-like inclusions of yellowish limestone exactly like the material that forms concretions in the shale of the Moreno in the vicinity and different from any material observed in place in the Martinez (?). These inclusions are believed to be pebbles derived from the erosion of the Moreno, but this can not be affirmed definitely.

In general, however, the line of separation between the two formations is not sharp and they seem to grade into each other. This in itself does not constitute proof of continuous sedimentation, but it makes the correct position of the line between the Moreno and the Martinez (?) difficult to determine. In most of the region south of Panoche Creek the line as here fixed lies in the midst of a belt of dark shale, the basal beds of the Martinez (?) being fine clay shale with lenticular sand inclusions and the upper beds of the Moreno being either similar clay shate or chocolate-colored siliceous and argillaceous shale. The locality in which the evidence most strongly suggests that sedimentation was continuous is in the region north of Little Panoche Creek. Here not only does the uppermost shale of the Moreno gradually become more sandy toward the top and seem to grade into the fine-grained fossiliferous sand that has been mapped as the base of the Martinez (?), but included in the Moreno and separated from the Martinez (?) by about 200 feet of shale of organic origin is a layer of gray sand 200 or 300 feet thick of identically the same type as the basal beds in the Martinez (?) formation. Before fossils were found in these beds it was thought that they and the sandstones in the lower part of the Martinez (?) were certainly portions of the same formation, and in the field the two layers of sandy beds were termed the lower and upper gray sands, respectively. The fossil faunas contained in the beds; however, are very different, that occurring in the "lower gray sand" and the overlying shale of organic origin being what is usually considered typical of the Upper Cretaceous, whereas that in the "upper gray sand" is typical of the early Tertiary.

The fact that the line between the Moreno and Martinez (?) formations is supposed to represent the line of separation between the Cretaceous and Tertiary systems gives it special importance and lends interest to the fact that the indications of unconformity are scant and aside from the paleontologic evidence are met by indications very suggestive of conformity. The faunal evidence is indicative of a long separation in time, but it is difficult to suppose the existence of a 
very great structural hiatus, in the face of such evidence as the strong similarity and seeming gradation of one formation into the other, their similar structure, and the relative constancy through this extensive region of the surface on which the Eocene beds were laid down. It is a noteworthy fact that the line between the Cretaceous and Tertiary systems should be so obscure and discoverable only on the evidence of a paleontologic break and detailed tracing of the beds through a long distance. The obscurity of the plane of separation is illustrated by the fact that no previous workers in this region have recognized the true position of the contact between the Cretaceous and the oldest Tertiary here present. The consequence is that no statements heretofore made as to the relation of the two systems have been founded on what appear to be correct premises.

The relation of the Martinez (?) formation to the overlying Tejon formation may be stated with more assurance to be one of unconformity. In the southern part of the region the existence of such an unconformity is shown by the fact that the Tejon completely overlaps the Martinez (?) within a distance of 18 miles to the north and the same to the southeast of the area near New Idria, where these beds are best developed. Beds at various horizons in the Martinez (?) come into contact with the Tejon before that formation finally hides the Martinez (?) entirely and rests upon the Moreno formation. The progressive elimination of the Martinez (?) beneath the Tejon is thought to be due to its having been eroded during the period intervening between its deposition and the deposition of the Tejon. At no place has a good example of discordance of dip been found in an exposure of the contact between these two formations, but at many places the basal fossiliferous beds of the Tejon may be seen lapping over the Martinez (?) in a way strongly suggestive of unconformity. Dumble, in the paper already cited, has noted in the uppermost beds here discussed as Martinez (?) burrows that are filled with sand like that of the overlying Tejon. This he offers as an indication of unconformity between the two formations.

EVIDENCE OF AGE.

In the southern part of the region fossils occur scattered sparingly through the Martinez (?) formation from the base nearly to the top. The fossils occurring in the glauconitic sand at the base of the formation have already been mentioned. This fossiliferous bed has also been noted and some of its fossils listed in the second paper by F. M. Anderson, ${ }^{1}$ and in the paper by Dumble. ${ }^{2}$ Besides these, Eocene fossils are found rather abundantly in the upper part of the clay shale near its contact with the overlying Tejon. The faunas of both the lower and the upper beds contain many species that are present

${ }^{1}$ California Acad. Sci. Proc., 4th ser., vol. 3, p. 13, 1908. 2 Jour. Geology, vol, 20, No. 1, p. 32, 1912. 
in the overlying Tejon, and on the whole both probably resemble the fauna of the Tejon as known in other regions more closely than they do that contained in the Martinez at the type section near San Francisco Bay. Yet, as these beds contain such lower Eocene fossils as Turritella pachecoensis, Arca biloba, and Glycymeris veatchi var. major, and rest unconformably below beds that contain a typical Tejon fauna, they can not well be mapped as Tejon and must either be designated by a new formation name or correlated tentatively with the Martinez until more evidence regarding their true position is available. The writers believe that the beds here described as Martinez (?) are probably the equivalent partly of the true Martinez and partly of the Tejon, and that the unconformity here registered in the Eocene is not to be correlated with that between the Martinez and Tejon formations in the Mount Diablo region.

TEJON FORMATION.

GENERAL FEATURES.

The Tejon formation, which overlies the Martinez (?) and embraces the upper part of the known Eocene strata, comprises beds of sandstone, conglomerate, and shale of marine and estuarine origin, which range in thickness from less than 50 to nearly 2,200 feet. It continues practically throughout the region, but, like most of the formations, the beds comprised in it in the southern part are somewhat different lithologically from those in the northern part. South of Panoche Creek it is formed of coarse, gritty brilliant-white to light-yellowish quartzose sandstone containing lenses and irregular beds of wellrounded pebbles; dark chocolate-colored to light-brownish carbonaceous shale; and a lesser amount of gray sandstone weathering to light yellow-brown and composed of grains of quartz and feldspar and of various rocks. In the northern part of the region the coarse white quartzose sandstone is less prominent and the beds of the formation are largely fine-grained, somewhat clayey micaceous gray sandstone, stained red and indurated in irregular layers by iron oxide; light-gray, somewhat gritty clay; and chocolate-colored carbonaceous shale. In both parts of the region the beds contain local lenses of coal.

\section{STRATIGRAPHIC RELATIONS.}

The Tejon is believed to rest unconformably upon the older strata throughout the region. Its relation to the Martinez (?), upon which it rests in most of the region south of Pacheco Pass, has been discussed in the description of that formation. North of Pacheco Pass the Tejon rests upon the Moreno formation (Upper Cretaceous), with which it is evidently unconformable. In parts of the north end of the region, however, notably between Garzas and Puerto creeks, the 
Tejon seems to grade into the underlying Moreno, and no lithologic or structural evidence of an interruption in sedimentation was discovered. Nevertheless such an interruption must have taken place, for there are no strata which might be considered the equivalent of the Martinez between the fossiliferous beds of the Tejon and those of the Moreno.

The relation of the Tejon to the overlying formations is not so clearly shown, but it is believed to be one of unconformity in most if not all of the region. From a point beyond the south end of the region as far northward as Salado Creek the Tejon is overlain by diatomaceous and foraminiferal shale which constitutes the formation mapped as the Kreyenhagen shale. This shale contains a rather meager fauna, and its exact age is a matter of doubt. In the Coalinga report ${ }^{1}$ it was mapped and discussed tentatively by Arnold and Anderson as the upper part of the Tejon formation because it overlies and seems to grade into the fossiliferous sandstone and clay shale of that formation. It was stated, however, that the shale of organic origin might possibly be separated unconformably from the known Tejon and that it might be of post-Eocene age. After a study of the region north of Coalinga it is now believed that such an unconformity exists in the region under discussion, or at least in portions of it. The evidence available makes it more probable that a time interval separated the deposition of the Tejon formation and that of the Kreyenhagen shale than that they were laid down during a period of continuous deposition. The chief evidence of such an unconformity is as follows:

1. The Tejon is not exposed for a distance of at least 5 miles on the north side of The Vallecitos, and in a portion of this distance the Kreyenhagen shale is exposed resting upon the dark clay shale of the Martinez (?). A like condition prevails from a point near the divide between Tumey Gulch and Panoche Creek to a point about 2 miles north of Panoche Creek. Moreover, just north of Arroyo Hondo and also between Ciervo Mountain and Tumey Gulch the Tejon formation thins perceptibly and is in a few places probably absent. It may be that the Tejon was never deposited in these areas, or that it was removed by erosion prior to the deposition of the Kreyenhagen shale. If the latter supposition is true an unconformity is proved, but in either case an earth movement between the epochs represented by these two formations must have taken place.

2. The thickness of the Tejon is variable, ranging from less than 50 feet to over 750 feet through relatively short distances in the southern portion of the region and reaching a maximum of over 2,000 feet in the northern portion.

3. The marked difference in the lithology of the beds comprised in the Tejon and in the Kreyenhagen when these formations are viewed as a whole and the difference in the faunas are suggestive of a break

\footnotetext{
1 Geology and oil resources of the Coalinga district, Cal.: U. S. Geol. Survey Bull. 398, p. 62, 1910.
} 


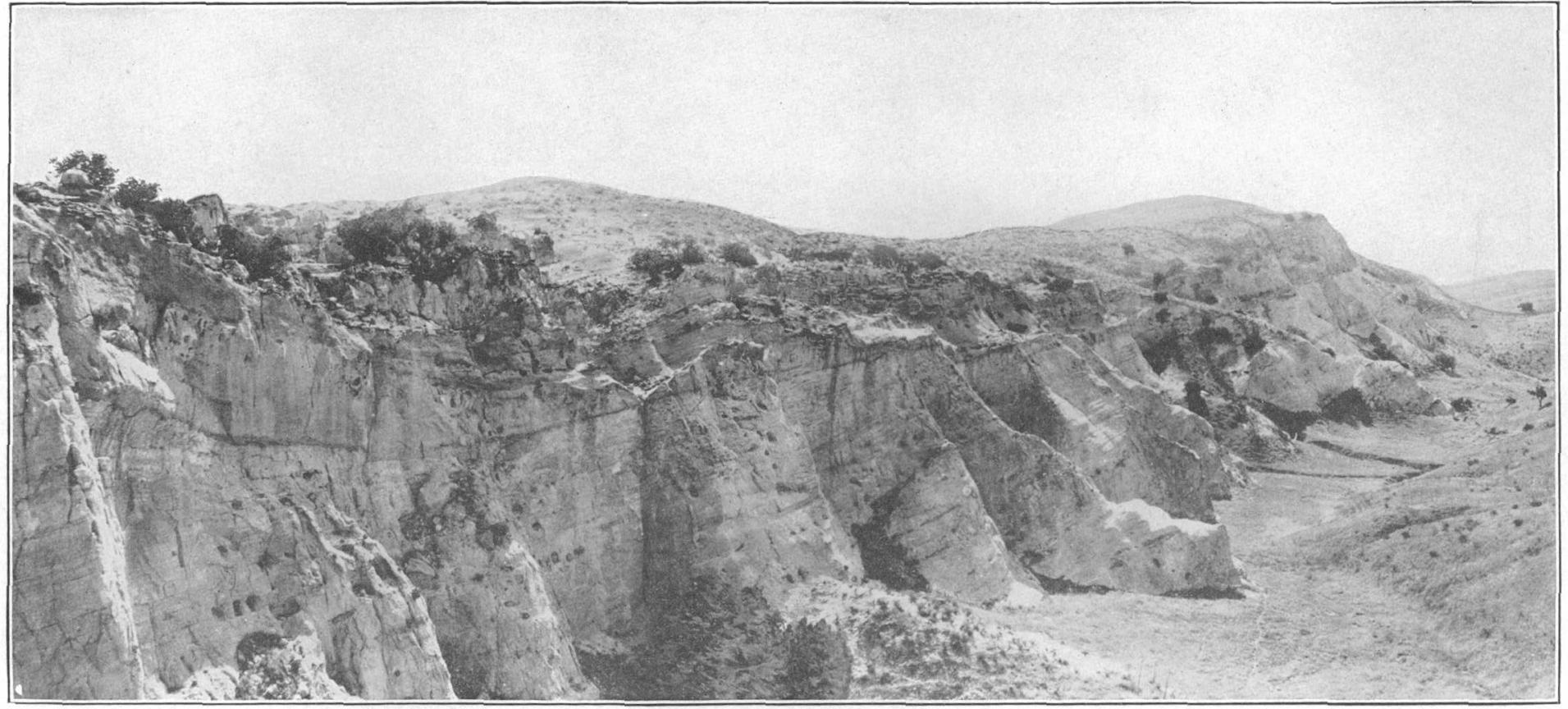

TYPICAL CLIFFS OF WHITE QUARTZOSE SANDSTONE OF THE TEJON FORMATION, IN THE CANTUA REGION.

Looking south from the divide between Cantua and Salt creeks. The Tejon here is formed almost wholly of sandstone and contains but little of the carbonaceous shale which becomes so abundant about The Vallecitos. 
in sedimentation, although it must be admitted that this indication can not be given great. weight in view of the sharp changes from detrital sediments to deposits of purely organic origin that take place within formations in this region, notably in the Moreno and Vaqueros formations.

This evidence in favor of an unconformity is in part offset by the facts that the two formations appear everywhere conformable in dip, that in many places they seem to grade into each other, and that they are closely associated and almost coextensive throughout this region and the Coalinga region to the south. Too much reliance should not be placed on these facts as indicating conformity, however, for in this same region other formations which are certainly unconformable seem to show a perfect gradation one into the other and are in similarly close association throughout a wide region. Even if the two formations are unconformable in the southern part of the region it is possible that near Orestimba Creek, where the Tejon has a greater thickness than to the south, they may be conformable. No evidence of unconformity was observed in this northern area, and it would seem natural that if one existed the areal mapping would show it more readily here, where the dips are low.

\section{DISTRIBUTION AND IITHOLOGY.}

As the lithology of the Tejon varies considerably throughout the region the formation can best be described by treating the areas of outcrop separately.

AREAS SOUTH OF PANOCHE CREEK.

The white sandstone of the Tejon formation south of Panoche Creek, although variable both in thickness and in lithology, is of so striking a type and may be so easily traced that it is of the utmost service in deciphering the structure of the region. It is formed mainly of rather coarse, white quartzose sandstone with a few irregular, pebbly layers or lenses and a considerable amount of carbonaceous shale. In the south end of the region mapped the sandstone is not of the white quartzose type but is usually a gray fine to medium grained arkose sandstone, only locally well cemented. In places it contains large brownish sandstone concretions, and some of it is greenish and glauconitic. Conglomeratic zones are rather common. For the most part it weathers to yellowish, irregular outcrops. North of Salt Creek it is brilliantly white, poorly cemented, and friable and weathers to prominent outcrops forming in places almost vertical cliffs 100 feet or so in height. (See Pl. VII.) This white sandstone is remarkable in that it contains almost no grains of feldspar and igneous rocks, such as form a large part of practically all the other sandstones in this region. It is composed predominantly of sub- 
angular grains of clear or milky-white, opaque quartz and quartzite, loosely compacted, friable, and forming massive beds which lend themselves readily to the erosive action of the wind. It is somewhat cross-bedded and contains various narrow and irregular pebble beds or lenses. The pebbly layers are formed of well-rounded fragments, usually not over 1 inch in diameter, and most of them are either light gray or jet-black quartz or quartzite. Only a few stray fragments of porphyritic or other igneous rocks were seen. The jet-black pebbles are particularly noticeable against the pure white sandstone background. The pebbly layers occur at several horizons in the Tejon, and no regular zone which might be termed a basal conglomerate was observed. The shale interstratified with the sand is light brownish or chocolate-colored and is very. carbonaceous. In places it contains good-sized but lenticular beds of coal which have been worked locally.

The thickness of the Tejon formation varies greatly south of Panoche Creek. At the head of Oil Canyon it;is about 200 feet. Northward from this locality to Salt Creek it varies from 200 to at least 750 feet. From Salt Creek nearly to-Ciervo Mountain it averages about 200 feet but in places is no. more than 50 feét, and locally, as for a short distance just north of Arroyo Hondo, the formation is almost if not entirely lacking. On the southwest flank of Ciervo Mountain it lies as a broad sheet between 200 and 250 feet thick, broken and folded along irregular lines, and dissected by numerous arroyos. Around The Vallecitos also the formation varies greatly in thickness. It reaches a maximum of at least 600 feet near San Carlos Creek, but through most of its extent here is much thinner and in the Griswold Hills is locally absent. On the south flank of Cerro Bonito Ridge for at least 2 miles west of Griswold Canyon it maintains a thickness of not less than 250 feet.

AREAS IN THE PANOCHE HILLS.

In the southeast corner of the Panoche Hills the Tejon has a thickness of 300 or 400 feet. It is formed mainly of fine-grained gray sandstone, which weathers easily to dark brown, interstratified with sandy shale, but in places the beds are coarse-grained or even almost pebbly. Fossils are abundant, usually occurring in hard, coarse to fine grained sand hardened somewhat by lime and weathering to a seal-brown color. To the north, on the northeast flank of the hills, the Eocene beds increase in thickness to a maximum of about 1,100 feet. The upper part of this succession is of Tejon age, as shown by the fossils it contains, but, as has already been explained, the lower part may be Martinez (?). For the present the whole is mapped as Tejon. These beds are mainly soft fine-grained gray-white sandstone stained by iron oxide in irregular reddish or yellowish-red bands and 
blotches and containing a few sandstone concretions. Near the top are irregular layers of hard, gray calcareous, rather coarse grained sandstone which weathers dark brown and contains typical Tejon fossils.

AREA BETWEEN LITTLE PANOCHE AND ORTIGALITO CREEKS.

Between Little Panoche and Ortigalito creeks the beds mapped as Tejon have a thickness of 150 to 250 feet. They consist mainly of rather fine grained, incoherent white sandstone containing narrow, irregular beds or lenses of well-rounded pebbles of quartzite and porphyry. Bedded with the sandstone are a few thin layers of light chocolate-colored clay shale containing numerous impressions of plants. The beds are almost identical in lithology with the white sandstone of the Tejon in the Cantua region, differing from it mainly in being finer grained, in containing a little dark mica, and in containing numerous pebbles of porphyritic rocks as well as those of quartz and quartzite. No fossils were found in these beds, but their peculiar lithology and their general stratigraphic position make their correlation with the Tejon to the south seem certain. They rest upon the massive fine-grained arkose gray concretionary sandstone of the Martinez (?) formation. The line of separation between the Martinez (?) and the Tejon is somewhat indefinite, but the line as mapped between the gray and the white sandstone marks the greatest change in lithology in the succession of beds from the top of the Moreno formation to the base of the Kreyenhagen shale. At the top the beds mapped as Tejon seem to grade upward into the Kreyenhagen shale through a zone about 50 feet thick, and the exact upper limit of the formation is difficult to determine.

AREA BETWEEN QUINTO AND HOSPITAL CREEKS.

Between Quinto and Puerto creeks the Tejon has a maximum thickness of at least 2,100 feet, but through most of the distance the exposed - thickness is somewhat less, owing to the unconformable overlapping of the San Pablo formation and probably also of the beds mapped as undifferentiated Miocene. In this area the formation is composed predominantly of very fine grained light-gray clayey sandstone with interstratified beds of slightly gritty clay or clay shale. In general the upper part of the formation is somewhat finer grained than the lower. It is not divisible into any well-defined lithologic zones, but several narrow zones stand out from the bulk of the formation and are of service in determining the structure. The most prominent of these is what was termed in the field the lower iron-shell zone. It ranges from 50 to about 150 feet in thickness and is traceable from a point a little north of Quinto Creek almost to Salado Creek, between 400 and 800 feet above the base of the formation. It is formed of fine-grained friable light-colored sandstone like that making up the bulk of the 
Tejon but differing from the rest of the beds in that it is heavily stained by iron oxide. In places the iron has given a purplish tint to the whole zone, but more commonly it has hardened the sandstone in irregular layers or nodules, some of them 16 inches thick, which weather out over the surface of the zone into an abundance of loose fragments. A second zone similar to this but not so persistent nor so heavily iron stained is present about 1,500 feet above the base and is traceable from the vicinity of Garzas Creek to Orestimba Creek. This was termed in the field the upper iron-shell zone. The iron-stained nodules are characteristic of the sandstone of the Tejon to a greater or less extent throughout the region between Coalinga and Tesla. They are believed to be of the nature of bog iron and to be indicative of swampy conditions during the period of deposition of the beds. Between 150 and 200 feet below the base of the lower iron-shell zone is a fossiliferous zone characterized by an abundance of Placunanomia inornata and traceable more or less continuously from the vicinity of the Cleveland School, near the south edge of Stanislaus County, to Salado Creek. On Orestimba Creek the base of this zone lies between 300 and 400 feet above the line mapped as the base of the Tejon. Near Garzas Creek beds containing poorly preserved fossils believed to be Placunanomia rest directly upon the fossiliferous sandstone of the Moreno.

AREA NEAR TESLA.

The Tejon formation as exposed along Corral Hollow Creek comprises very fine clay and clay shale, carbonaceous shale, fine-grained micaceous gray sandstone, heavily stained by iron in local areas, concretionary sandstone, and gritty or pebbly white sandstone. Near Tesla, where these beds have their greatest development, they are apparently about 1,400 feet thick, but as the strata are broken by numerous small faults it is possible that in the measurement the section was duplicated in part. Between Tesla and Carnegie, where faults are not so prominent a feature, this formation is about 1,000 feet thick. The general lithologic character of the Tejon here and in the hills near Orestimba Creek is very similar, except that in the northern region the gritty or conglomeratic beds are much more prominent. These beds are much like the gritty beds in the overlying undifferentiated Miocene near Tesla and are with difficulty separated from those beds. One of the most distinctive features of the Tejon here is the abundance of iron-stained hardened beds similar to the beds near Orestimba Creek. Coal occurs in the lower part of the Tejon at Tesla and has been mined rather extensively. The mines were in 1910, however, worked for the clay overlying the coal. A small exposure of very carbonaceous clay shale and white gritty sand occurs on the north side of Corral Hollow Creek within half a mile of the point where it empties into the San Joaquin Valley. These beds are mapped as 
Tejon because of their lithologic similarity to the beds near Tesla. The heavily iron-stained white sandstone and brownish carbonaceous clay shale between Lone Tree and Corral Hollow creeks are also mapped as Tejon for a similar reason, although no diagnostic fossils were found in them.

\section{RELATION TO PETROLEUM.}

The Eocene formations have some importance with relation to petroleum, owing to their stratigraphic position above the oil-bearing shale of the Moreno formation (Upper Cretaceous) and below that of the Kreyenhagen (Oligocene ?) and owing to the possibility of oil entering them from these formations. At the north end of the Coalinga district valuable accumulations of oil occur in the Eocene, and farther north they merit careful study, although no pools of oil have been found in them outside of the Coalinga district.

In most of the region the upper part of the Moreno formation, upon which the Eocene beds rest, consists largely of shale of organic origin, which is believed to be the ultimate source of the petroleum obtained in the wells near Oil City, in the Coalinga field, and in those drilled near Griswold Canyon, at the west end of The Vallecitos. Where the structure is favorable and the beds in the lower part of the Eocene section are relatively porous, those beds, whether they are part of the Martinez (?) or part of the Tejon formation, might be expected to serve as a reservoir for oil rising from the underlying shale. In the district between Pacheco Pass and Puerto Creek the upper few hundred feet of the Moreno, upon which the Tejon rests, is formed of rather coarse sandstone. In this part of the region, therefore, the Tejon would not be considered the most probable reservoir for any oil which might have come from the shale of organic origin in the Moreno formation, as any such oil would naturally collect in the porous sandstone beds at the top of that formation.

It is possible that oil which had its origin in the overlying organically formed Kreyenhagen shale may have migrated into the more porous sandstone of the Tejon, or even into sandy beds in the Martinez (?), where the Tejon is thin. It is not believed, however, that any considerable amount of oil has moved downward from the Kreyenhagen shale and collected in appreciable quantity in the Eocene formations in this region.

The chocolate-colored carbonaceous shale that occurs in the Tejon formation in most parts of the region closely resembles the argillaceous facies of the diatomaceous shales occurring in the Kreyenhagen and Moreno formations. It may be formed in part of diatoms, although a careful microscopic search failed to reveal them. Traces of oil were detected in a sample of this shale obtained north of New Idria, by carefully treating it in the laboratory with various solvents. The presence of the oil in this bed suggests the further possibility 
that petroleum may have been formed in the Tejon itself from minute organisms such as diatoms which the shale may contain, or from the remains of larger terrestrial vegetation of which the shale shows abundant traces. This is merely a matter of conjecture, however, and the occurrence is rather one of scientific interest than practical importance, inasmuch as the quantity of oil which these shaly beds now show is extremely minute, and the beds themselves are not thick.

OLIGOCENE (?) SERIES.

KREYENHAGEN SHALE.

GENERAL FEATURES.

Overlying the known Eocene strata is a body of white diatomaceous and foraminiferal shale and clay shale which has a maximum exposed thickness of a little over 1,500 feet. It is a marine deposit formed largely of the siliceous tests of diatoms and constitutes one of the largest and most homogeneous masses of such material yet discovered. This shale is closely associated with oil-bearing strata in the Coalinga district and is believed to have been the original source of most of the petroleum of that field. It is therefore of special interest in the present discussion. In the report on the Coalinga district this body of shale was included tentatively with the Tejon (upper Eocene) and treated as an upper member of that formation, although the possibility of its being of Oligocene age was pointed out. Positive evidence as to the exact age of this shale is still lacking, but numerous facts lead to the belief that it constitutes a distinct formation more recent in age than the Tejon. This conclusion, combined with the evidence afforded by the fauna, which, though meager, is distinct from that of the underlying and overlying formations and is suggestive of the Oligocene, warrants the tentative assignment of these beds to the Oligocene series. Inasmuch as the Martinez (?) formation presumably represents the earlier portion of the Eocene and the Tejon formation the later portion, the greatest age assignable to this shale is late Eocene. On the other hand, it is believed to be certainly of pre-Miocene age owing to the important hiatus represented by the unconformity at its top, which separates it from the Vaqueros, the oldest formation here of undoubted early Miocene age. The chief reasons for describing it as a separate formation are $(a)$ that it is a homogeneous body of strata of marked persistency, evidently deposited in one basin under constant and rather unusual conditions during a continuous epoch of sedimentation; $(b)$ that it is separated faunally from the formations above and below; $(c)$ that it is probably unconformable on the Tejon formation (later Eocene) below and is marked off by a very important unconformity from the Vaqueros formation (lower Miocene) above; and $(d)$ that it consti- 


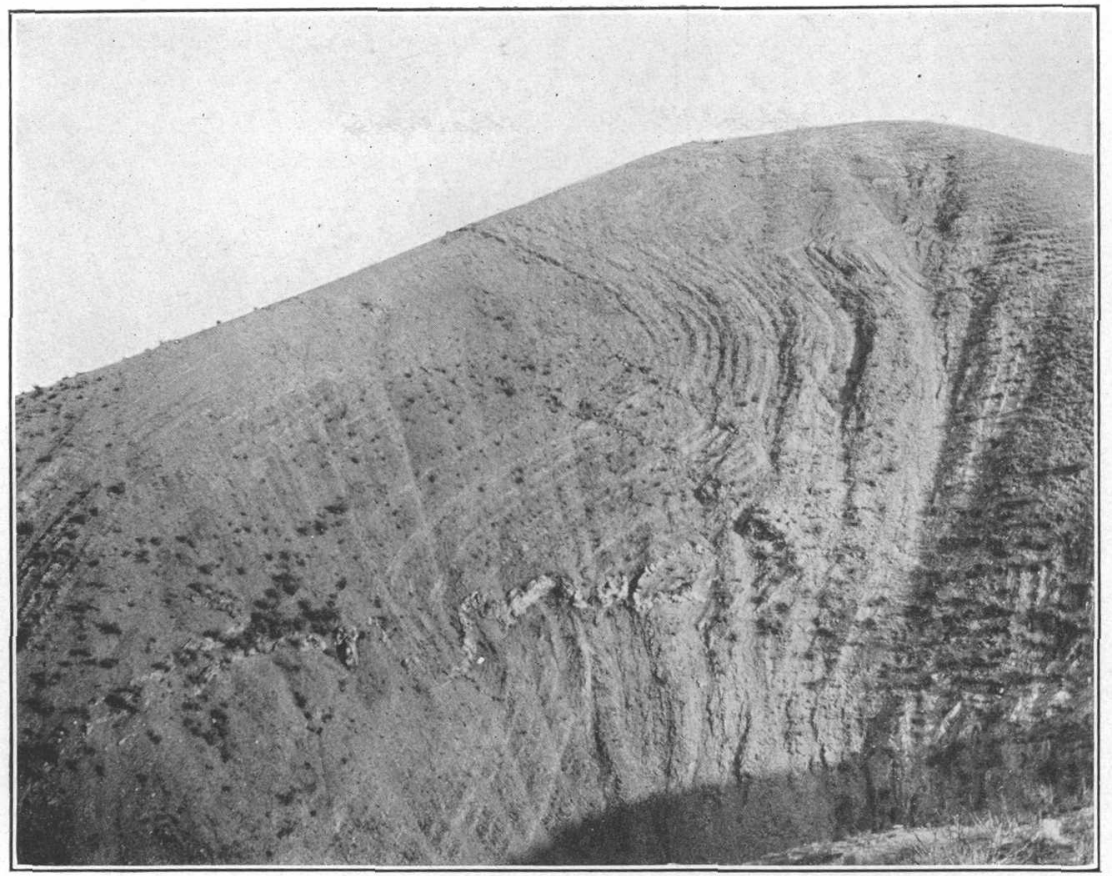

A. TYPICAL EXPOSURE OF THE SILICEOUS KREYENHAGEN SHALE ON DOMENGINE CREEK, SHOWING CHARACTERISTIC SURFACE CRUMPLING.

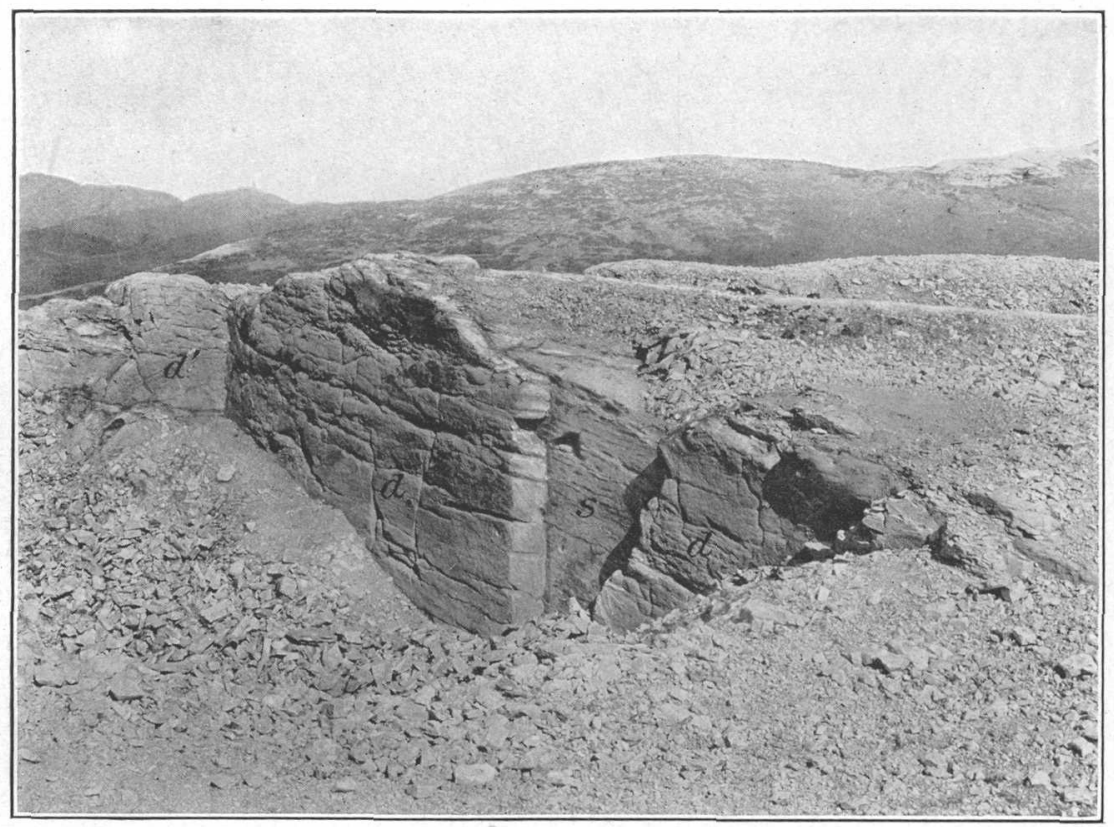

B. SANDSTONE DIKES IN THE KREYENHAGEN SHALE.

Small pit about half a mile north of George Crow's ranch house near Orestimba Creek. The shale $(s)$ dips at a low angle to the right. Its attitude is shown near the top of the cut. A sandstone dike $(d)$ standing vertical trends diagonally across from lower right-hand corner. At the left it joins a second dike $\left(d^{\prime}\right)$ at right angles. 


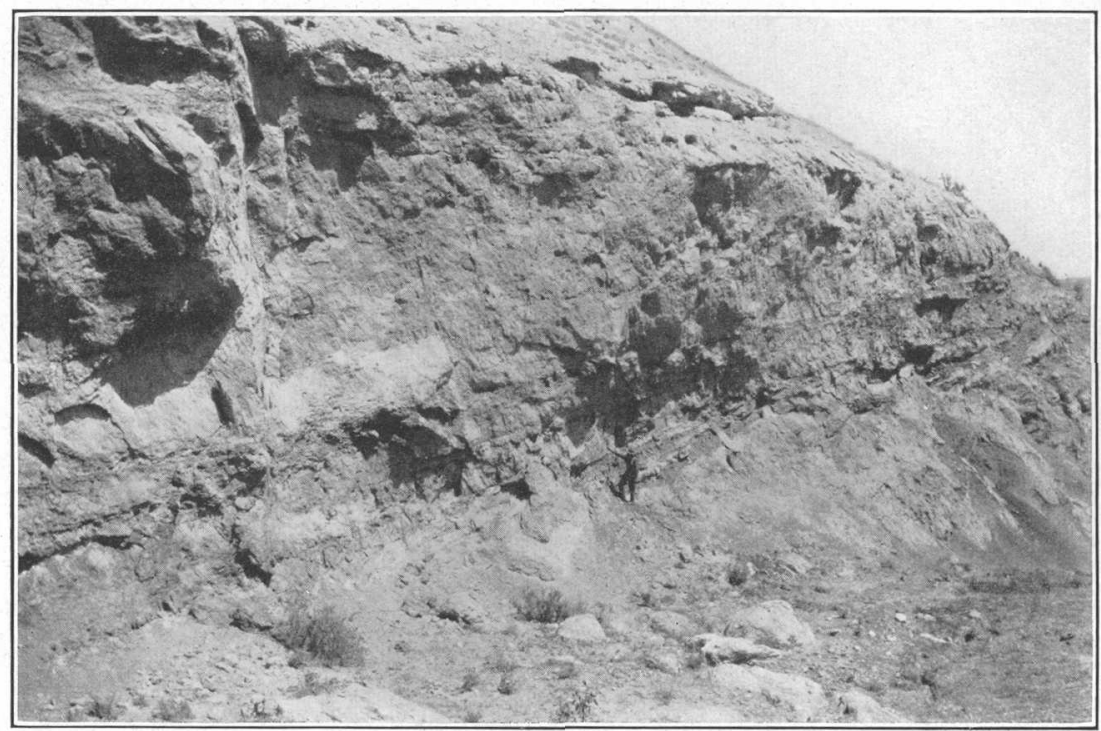

A. UNCONFORMITY OF THE OIL SANDS OF THE VAQUEROS FORMATION ON OILY KREYENHAGEN SHALE ALONG SILVER CREEK.

Looking north at bank of creek below New Bedford well.

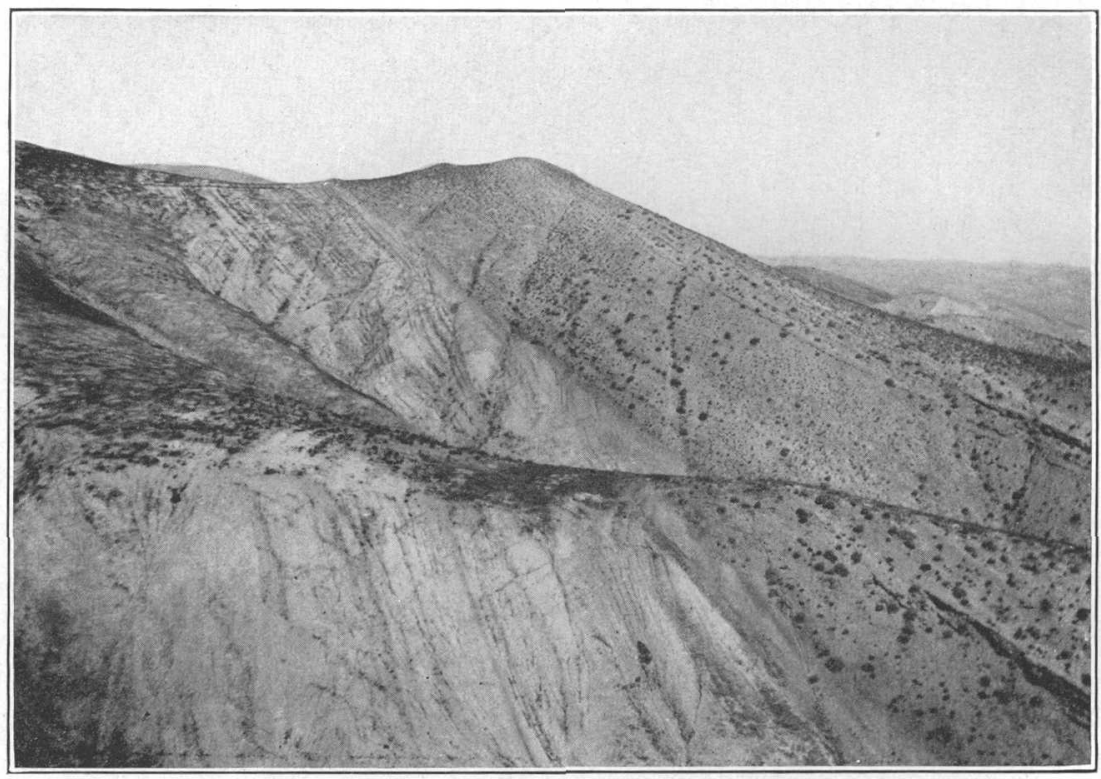

$B$, UNCONFORMITY OF SANDSTONE OF THE VAQUEROS FORMATION ON KREYENHAGEN SHALE ALONG THE EAST FACE OF THE CIERVO HILLS. 
tutes an excellent cartographic unit. For reasons to be discussed further on it is designated the Kreyenhagen shale, from its type locality in the Kreyenhagen fièld south of Coalinga.

LITHOLOGY.

The Kreyenhagen shale is one of the most widespread of the Tertiary formations in the east flank of the Diablo Range. Throughout its extent it varies relatively little in lithologic character compared to the other Tertiary and Cretaceous formations. It is predominantly of organic origin, consisting mainly of light-colored diatomaceous shale very similar in character to the shale that overlies the Vaqueros formation and forms so large a part of the Monterey group (Miocene) in other portions of California. It contains almost every gradation from white massive-weathering diatomaceous earth to thin-bedded porcelaneous or flinty shale. Under the microscope it is seen to be formed very largely of the skeletons of diatoms, with less numerous foraminifers. In a few calcareous layers and nodules foraminifers are predominant. Interbedded with this shale typically of organic origin are beds of slightly carbonaceous clay shale and fine sand, both of which are especially common in the lower part of the formation. The siliceous shale of organic origin weathers almost pure white and locally forms hill surfaces without soil cover and almost bare of vegetation which are easily recognizable at a considerable distance. (See Pls. II and X.) On fresh exposures, especially where the content of clay is large, the color is a light chocolate-brown; locally it is dark brown or almost purplish brown. Gypsum is abundant, occurring both in efflorescent deposits intimately mixed with the earthy shale and as pure selenite in plates or veins from a fraction of an inch to 12 or 14 inches thick. The shale is traversed by innumerable sandstone dikes which range from narrow stringers less than an inch thick to masses several feet across. These dikes cross the bedding at all angles or lie parallel with it and are with difficulty distinguished from sandstone interstratified with the shale. Characteristic exposures of the Kreyenhagen shale cut by sandstone dikes are shown in Plate VIII.

\section{STRATIGRAPHIC RELATIONS.}

The Kreyenhagen shale is believed to rest unconformably on the Tejon throughout the region, with the possible exception of the area between Garzas and Puerto creeks. The evidence bearing on its relation to the Tejon has been given in the description of that formation. Its relation to the overlying formation is more clearly shown than is its relation to the underlying one and, possibly except in the area between Garzas and Crow creeks, where its relation to the beds mapped as undifferentiated Miocene is not certainly one of 
unconformity, the Kreyenhagen shale is unquestionably overlain unconformably by younger strata. South of Panoche Creek it is overlain by the Vaqueros formation (early Miocene), with which it shows distinct angular unconformity. This unconformity is widespread and represents one of the major breaks in the sedimentary record in this region. Distinct angular discordance in dip was noted at several places (see Pl. IX), and near Ciervo Mountain the basal bed of the Vaqueros formation westward from the edge of the San Joaquin Valley lies on successively lower beds of the Kreyenhagen shale. North of Panoche Pass, with the exception noted above, the Kreyenhagen shale is overlain by the San Pablo (upper Miocene) and Tulare (?) (Pliocene and Pleistocene?) formations, with which it shows a distinct discordance in dip.

PREVIOUS DESCRIPTION AND CORRELATION.

The siliceous shale here under discussion was almost universally and very naturally considered to be the equivalent of similar shale in the Monterey group (Miocene) by the geologists who first visited the Coalinga region. This opinion was shared by Watts, ${ }^{1}$ by Eldridge, ${ }^{2}$ and originally by F. M. Anderson. ${ }^{3}$ Anderson, however; on further study recognized its Eocene or Oligocene age. ${ }^{4}$ Ralph Arnold and Robert Anderson ${ }^{5}$ treated it tentatively as a portion of the Tejon formation (Eocene), although recognizing the possibility of its being a separate formation of later Eocene or Oligocene age. The formation as described in the present report is the continuation and equivalent of the beds called in the Coalinga reports the "upper member of the Tejon" or the "shale overlying the sandstone of the Tejon."

The name Kreyenhagen shale is applied to this formation because it is believed to be with little doubt the equivalent of the formation along Reef Ridge, in the southern portion of the Coalinga district, that was termed the Kreyenhagen shales by F. M. Anderson in the first of the two papars by him just cited. It should be stated, however, that the formation north of Coalinga that was termed by him the Kreyenhagen shales is entirely different from that described in the present report under the same name. It has been shown above, in the general description of the Moreno formation (p. 49), that the original description by F. M. Anderson of the Kreyenhagen shales is drawn from two different formations, one of Tertiary shale, exposed in the Kreyenhagen region, south of Coalinga, and the other of shale similar lithologically but of Cretaceous age, occurring north of Coalinga, in the south end of the region covered by the present report.

${ }^{1}$ California State Min. Bur. Bull. 3, 1894; Bull.19, 1900.

2 U. S. Geol. Survey Bull. 213, p. 307, 1903.

${ }^{3}$ California Acad. Sci. Proc., 3d ser., vol. 2, No. 2, pp. 168-173, 1905.

4 Idem, 4th ser., pp. 15-16, 1908.

5 U.S. Geol. Survey Bull. 398, p. 62, 1910. 
Of the two formations thus originally correlated with each other the Cretaceous shale north of Coalinga is described in the present report as the Moreno formation, and the Tertiary shale south of Coalinga will be called the Kreyenhagen shale, for the reason that the name was derived from the southern region. The formation to which the name Kreyenhagen is thus restricted consists largely of brittle siliceous shale of organic origin, and its outcrop forms a belt along Reef Ridge between the underlying fossiliferous sandstone of the Tejon (Eocene) and the overlying fossiliferous sandstone of the Vaqueros formation (lower Miocene). As the Tertiary shale of organic origin that occupies a similar stratigraphic position north of Coalinga is almost certainly the equivalent of the shale in the Kreyenhagen region it is described under the same name. It is noteworthy that a small body of siliceous shale of similar character and with little doubt of the same age is exposed in the Coalinga Westside field, a few miles northwest of the town of Coalinga, where it overlies the fossiliferous beds of the Tejon. This exposure forms a connecting link between the beds in the Kreyenhagen region and the correlated beds in the area mapped in the present report.

\section{DISTRIBUTION AND THICKNESS.}

Along the foothills bordering the San Joaquin Valley south of Little Panoche Creek the exposed thickness of the Kreyenhagen shale ranges from about 600 to 1,800 feet, the variation being due largely to the unconformity at the top of the formation. The formation is here roughly divisible into two parts. The lower part, comprising about two-thirds of the whole, is formed predominantly of clay shale, containing diatoms and foraminifers, but not nearly so abundantly as the shale in the upper part. The lower part is dark brown when fresh, but weathers to a light chocolate color. The basal beds in much of this region are very sandy and appear to grade into the underlying Tejon. The upper third of the formation is largely soft diatomaceous shale weathering to rather massive pure-white outcrops. In many places the Kreyenhagen shale is fractured and crumpled near the surface, and appears more sharply tilted than the overlying Vaqueros and underlying Tejon, so that dips taken in it are not always trustworthy. (See Pl. VIII.)

North of Little Panoche Creek the Kreyenhagen shale is exposed in two areas, one south and the other north of Pacheco Pass. In the area between Little Panoche and Ortigalito creeks the formation has a maximum exposed thickness of about 900 feet It is underlain by and seemingly grades into the sandstone of the Tejon formation. Overlying it with marked unconformity are coarse gravel and loose, incoherent brown sand, which constitute the San Pablo and Tulare (?) formations. The Kreyenhagen is in this area almost wholly very 
pure diatomaceous shale, with only a little of the clayey dark-brown shale like that present in the south. Between Garzas and Little Salado creeks the Kreyenhagen shale passes through the low terraced foothills, and is almost at the edge of the San Joaquin Valley. The maximum exposed thickness is 750 feet, but through much of the distance the thickness is less because of erosion before the deposition of the overlying beds. The shale is slightly more clayey and sandy than that exposed south of Ortigalito Creek, yet it is largely pure white and very diatomaceous, and it forms prominent outcrops along the west side of the low hills between George Crow's ranch and Crow Creek.

\section{RELATION TO PETROLEUM.}

The diatomaceous and foraminiferal Kreyenhagen shale is believed to have been the original source of the petroleum that is found in the Vaqueros, Santa Margarita (?), and Jacalitos formations in the Coalinga district, the oil having formed in the shale, migrated upward, and collected in the upper Tertiary beds. The shale is locally stained purplish by oil, and in a few places oil exudes from beds in contact with it, but so far as known there are no considerable reservoirs of petroleum in it, the oil having migrated to the more porous overlying strata. As exposed north of Coalinga the Kreyenhagen shale is very largely of organic origin and might be expected to have formed petroleum. Where the structure is favorable for the accumulation of oil the beds resting on this shale should be critically examined as possible oil reservoirs.

\section{MIOCENE AND PLIOCENE SERIES.}

\section{SUBDIVISIONS.}

Resting unconformably upon the Kreyenhagen shale south of Salado Creek and overlapping Eocene and Cretaceous rocks north of that stream is a succession of beds of sandstone, fine and coarse conglomerate, clay and clay shale, and a little diatomaceous shale. These beds are of Miocene, Pliocene, and perhaps in part Pleistocene age, and comprise a number of formations. They are mainly of marine origin, but at the top include beds of fluviatile origin. In the south end of the district the Miocene and Pliocene beds constitute the northward extension of those that were mapped in the Coalinga district as the Vaqueros formation (lower Miocene), the Santa Margarita (?) formation (upper middle Miocene), the Jacalitos' and Etchegoin formations (upper Miocene), and the Tulare formation (Pliocene and Pleistocene). North of Little Panoche Creek, the Miocene and Pliocene beds comprise the San Pablo formation (Pliocene or upper Miocene), and the Tulare (?) formation (Pliocene and Pleistocene). Near Tesla, near 
Orestimba Creek, and in the hills south of Llanada there are strata whose exact stratigraphic position is not known and which are mapped and discussed in the text as undifferentiated Miocene.

\section{RELATION TO PETROLEUM.}

Although these post-Eocene formations embrace a great variety of lithologic types their stratigraphic relations to the diatomaceous shales of the Kreyenhagen and Moreno formations are such that a few general statements regarding their economic importance will apply equally well to all of them.

The petroleum which occurs in the Coalinga district and in small areas in the region under discussion is believed to have originated in the diatomaceous and foraminiferal shales of the Moreno and Kreyenhagen formations. These shale beds are relatively impervious and do not as a rule form good reservoirs for retaining the oil. The petroleum therefore migrates to more porous strata and tends to collect in large part in the sandy beds immediately overlying the shales. It is to this fact that the Miocene and Pliocene series owe their importance in the problem of oil accumulation.

Throughout its extent in the region under discussion the Kreyenhagen shale is overlain by sandy beds mapped as Miocene and Pliocene. The basal sandy beds of this overlying mass, irrespective of the formation to which they belong, are the beds in which oil having its origin in the Kreyenhagen shale would be expected to collect. The principal oil-bearing measures along Anticline Ridge, in the Coalinga district, are the sandy beds in the Vaqueros formation which rest upon the Kreyenhagen shale. Along the edge of the San Joaquin Valley northward from the Coalinga district nearly to Tumey Gulch, and also in The Vallecitos, the Vaqueros forms the basal part of the mass mapped as Miocene and Pliocene. North of that locality the Vaqueros is lacking and younger beds form the lower part of the mass. Near Panoche Creek the Tulare (?) rests upon the Kreyenhagen shale, and it is probable that a short distance out from the edge of the foothills, beneath the cover of the valley alluvium, the Kreyenhagen is overlain by the Etchegoin and Jacalitos formations. In the foothills between Little Panoche and Ortigalito creeks and also near Crow Creek the Kreyenhagen is overlain by the San Pablo; between Garzas and Orestimba creeks the sandy beds described as undifferentiated Miocene rest upon it. In only a small part of these areas, however, do the structural conditions favor the supposition that oil has collected in the beds overlying the Kreyenhagen.

In the greater part of the region the Miocene and Pliocene series are not in contact with the Moreno formation. For the most part, therefore, they would not be expected to serve as a reservoir for oil $81281^{\circ}-$ Bull. $603-15-6$ 
that originated in the shale of the Moreno. In a small area near Tesla, however, the beds described as undifferentiated Miocene form the base of the Miocene and Pliocene series and rest upon the Cretaceous. In this area they contain oil that is thought to have originated in the Moreno formation. The occurrence of petroleum here is discussed more in detail in another portion of this report (p. 186).

\section{MONTEREY GROUP.}

\section{VAQUEROS FORMATION (LOWER MIOCENE).}

GENERAL FEATURES AND STRATIGRAPHIC RELATIONS.

In the southern part of the region the lower portion of the succession of Miocene beds overlying the Kreyenhagen shale is composed of marine sandstone, shale, and conglomerate that form the northward continuation of the beds mapped in the Coalinga district as the Vaqueros formation (lower Miocene), except that the Big Blue, which in the Coalinga report is included in the Santa Margarita (?) formation, is here included in the Vaqueros, for the reason that it has been found to contain typical Vaqueros fossils. The beds constituting this formation are the chief oil-bearing sands in the Coalinga district, and they are therefore of particular interest in the region to the north of that district in connection with the problem of finding oil. The formation is known only south of Panoche Creek. North of that stream it has not been certainly recognized within the region and occurs only in a very small area, if at all. It will be discussed under the designation Vaqueros formation to show its equivalence to the formation in the Coalinga region already so described, in accordance with the previous usage of that name in other portions of the California Coast Ranges for the sandstone beds of lower Miocene age that were formed in the early part of the period of apparently continuous sedimentation during which the shale of the Monterey group was deposited. This shale of the Monterey group, which in other parts of the Coast Ranges overlies the Vaqueros formation, is lacking, or at most occurs only in small areas in this region, and at least the greater part of the shale epoch of Monterey time is believed to be unrepresented by sediments here. There are some indications, both paleontologic and lithologic, that the Vaqueros formation may represent the epoch during which the lower portion of the shale of organic origin was deposited in some other places, but the settlement of this question must await detailed paleontologic work.

The beds here referred to as Vaqueros constitute a distinct stratigraphic unit representing an epoch of marine deposition widely separated in time from the epochs in which the preceding and succeeding formations were laid down. They afford the best illustration in this 
region of a unified set of strata formed during a period of deposition unquestionably preceded and terminated by epochs in which the region was above the sea and subjected to erosion. The unconformity of this formation upon the Kreyenhagen shale is marked by good structural evidence, as has already been shown in the description of that shale. This unconformity is well shown in Plate IX. The unconformable relation of the Vaqueros formation to the succeeding one is likewise clear, although the evidence is not so marked as in the case just mentioned. At one place north of Cantua Creek rounded bowlders containing fossils characteristic of this formation were found in the basal conglomerate of the succeeding formation, the Santa Margarita (?), which its own fossils indicate to be middle Miocene in age. Moreover, on Cantua Creek the upper strata of the Vaqueros contain Pholas borings, as if they had been exposed on the seashore before the succeeding beds were laid upon them. Bowlders of sandstone with Pholas borings, probably derived from these upper beds of the Vaqueros, are to be found in the overlying formation. These and other indications point convincingly to the presence of an important unconformity between the two formations.

The Vaqueros is exposed in three areas-one in the Big Blue and Ciervo hills, where it has an average thickness of 400 to 700 feet and a maximum thickness of about 1,000 feet; a second around the borders of The Vallecitos, where it has a maximum thickness of at least 1,500 feet, but is in most places between 700 and 1,000 feet; and a third on the south side of Panoche Valley near Llanada, where the maximum thickness is at least 1,100 and perhaps 1,500 feet. Regional deformation and erosion have separated the Vaqueros in these areas, but at one time the beds now occurring in them unquestionably formed parts of an unbroken sheet. The general character of the Vaqueros in these areas is not altogether the same. Along the foothills of the San Joaquin Valley it is formed mainly of variable fossiliferous sandstone, sand, and conglomerate, essentially near-shore marine deposits. In The Vallecitos a portion of the formation is like that along the foothills, but other parts of it are composed of fine sandy shale and diatomaceous shale, representing deposition in quieter and possibly deeper water. Near Llanada it partakes of the general character of the beds exposed in The Vallecitos, but in addition contains a considerable amount of fragmental volcanic material. The Vaqueros is easily recognizable by its beds of hard fossiliferous gray sandstone, which weathers to prominent outcrops and forms ridges. Along the foothills north of Coalinga the most striking feature of the formation is the upper portion, locally known as the Big Blue, which is formed almost wholly of serpentine fragments and in places looks not unlike a mass of serpentine in its original position. 


\section{AREA ALONG THE SAN JOAQUIN VALLEY.}

From Joaquin Ridge northward to Salt Creek the Vaqueros occupies a narrow belt in the Big Blue Hills and dips eastward at angles varying from $25^{\circ}$ to $60^{\circ}$. North of Salt Creek the formation enters into the irregular monoclinal fold whose axis lies about 2 miles from the edge of the San Joaquin Valley. Along the east side of the axis of this fold the formation dips steeply eastward, in some places almost vertically, beneath the younger Miocene. On the west side of the monoclinal axis the Vaqueros lies at various low angles, in places almost horizontal, capping the diatomaceous Kreyenhagen shale in irregular and more or less isolated areas. (See Pl. X.)

The Vaqueros varies in thickness from about 500 feet near Joaquin Ridge to almost 1,000 feet at Salt Creek, northward from which it gradually becomes thinner. It is overlapped entirely by younger Tertiary formations near Tumey Gulch and does not reappear north of the gulch. It is roughly divisible into two members-a lower one, formed chiefly of gray quartzose and arkose sandstone, and an upper one, which is known in the Coalinga field as the Big Blue and which is formed of detrital serpentine fragments. The upper member is much less extensive than the lower, being in the nature of a large lens. In this report it is called the Big Blue serpentinous member.

Lower member.-The sandstone of the lower member is usually fine to medium grained but is of varying coarseness, composition, and degree of induration. Most of it is comparatively loose and friable, and some beds are almost incoherent sand. Fossils are abundant in various beds and irregular lenses. In places the beds are hardened by the calcareous cement.derived from the fossil shells, and the sandstone weathers out into prominent reef-like outcrops similar to the hard calcareous "reef beds" so characteristic of the Vaqueros in the Coalinga region. The member likewise contains lenses of conglomeratic sandstone and irregular beds of clayey sand, and at two or more horizons there are thin beds of diatomaceous shale similar to that known as the "indicator bed" in the Coalinga region.

A striking feature of the sandstone in places is the blue color, which is caused by a semiopaque film that coats the grains. The film, although grayish in color, appears almost sky-blue where it overlies the dark-colored grains. The exact nature of this coating is not known. The writers suggest that it may be composed either of opal or chalcedony, that was secondarily deposited in the sandstone, of fine volcanic dust that settled on the surface of the water in which the sand was being deposited, or of clayey material resulting from the decomposition of portions of the sand. An analysis of the coating scraped from the coarse grains of a blue sandstone of identical type from the Etchegoin formation in the Coalinga district was made by W. F. 


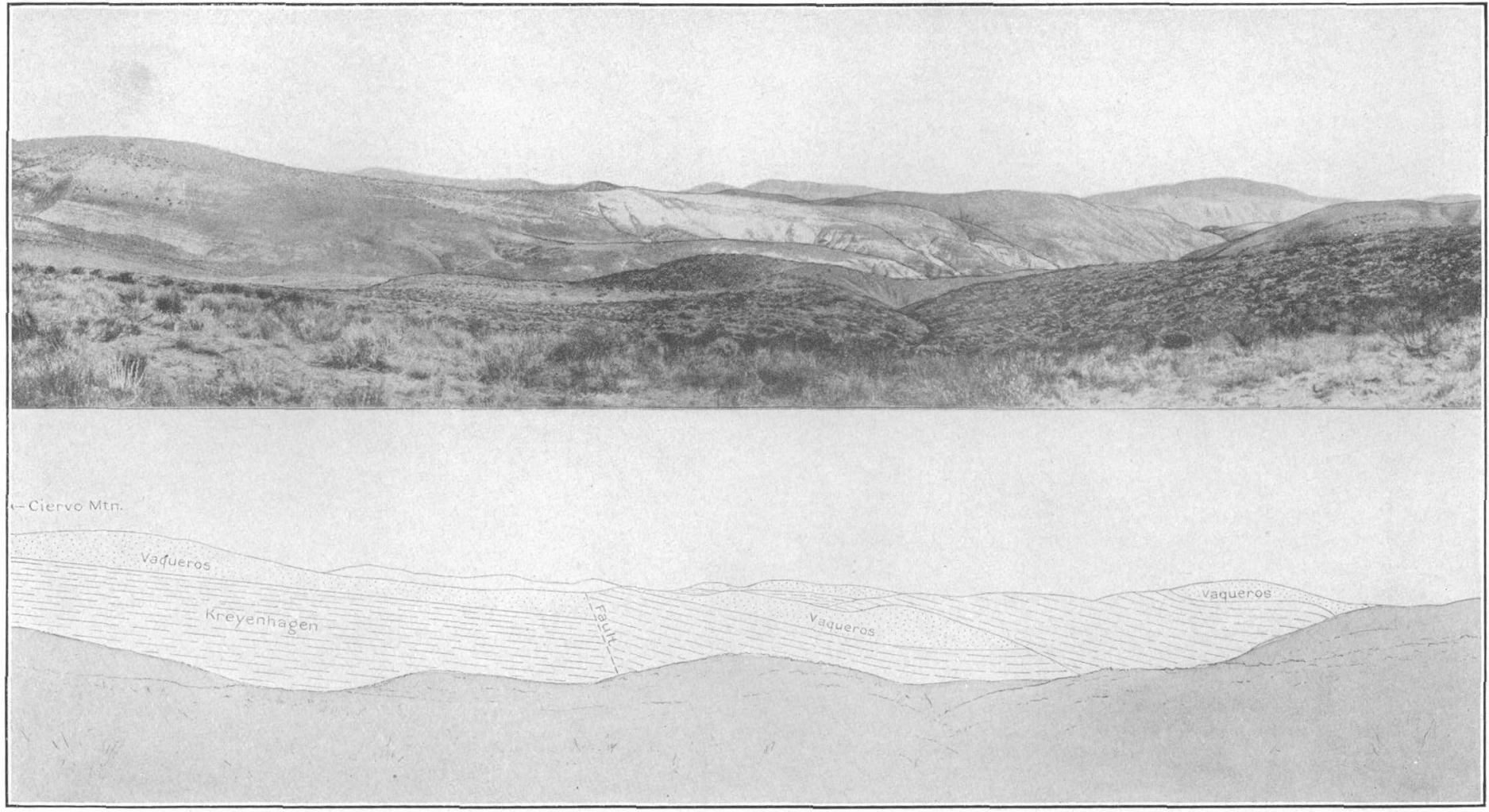

LOW-DIPPING BEDS OF THE KREYENHAGEN SHALE AND VAQUEROS FORMATION NEAR THE SOUTH END OF THE CIERVO ANTICLINE. Looking north and northeast across Arroyo Ciorvo from ridge $1 \frac{1}{2}$ miles east of Ciervo Mountain. 


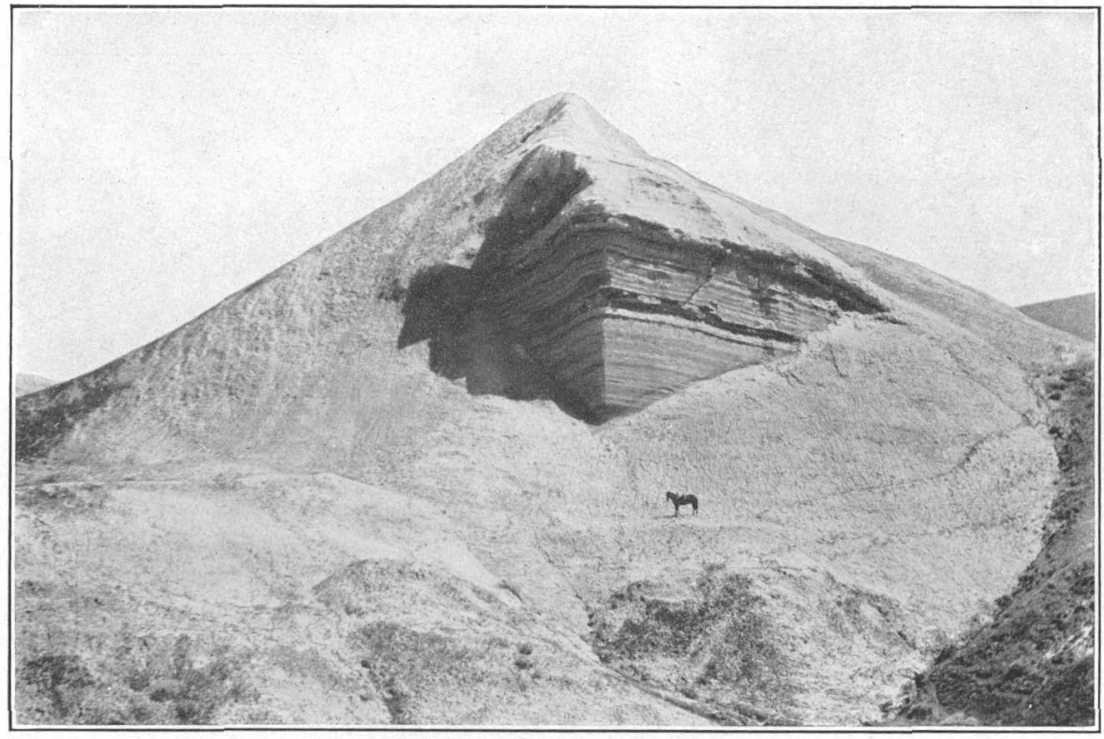

A. CHARACTERISTIC OUTCROP OF THE BIG BLUE SERPENTINOUS MEMBER OF THE VAQUEROS FORMATION NEAR CANTUA CREEK.

Looking east at outcrop about half a mile south of Arroyo Hondo. The central outcrop is formed of indurated green and brown shale composed of comminuted fragments of serpentine dorived from the serpentine area noar New Idria. Its freedom from fragments of quartzose rocks is remarkable.

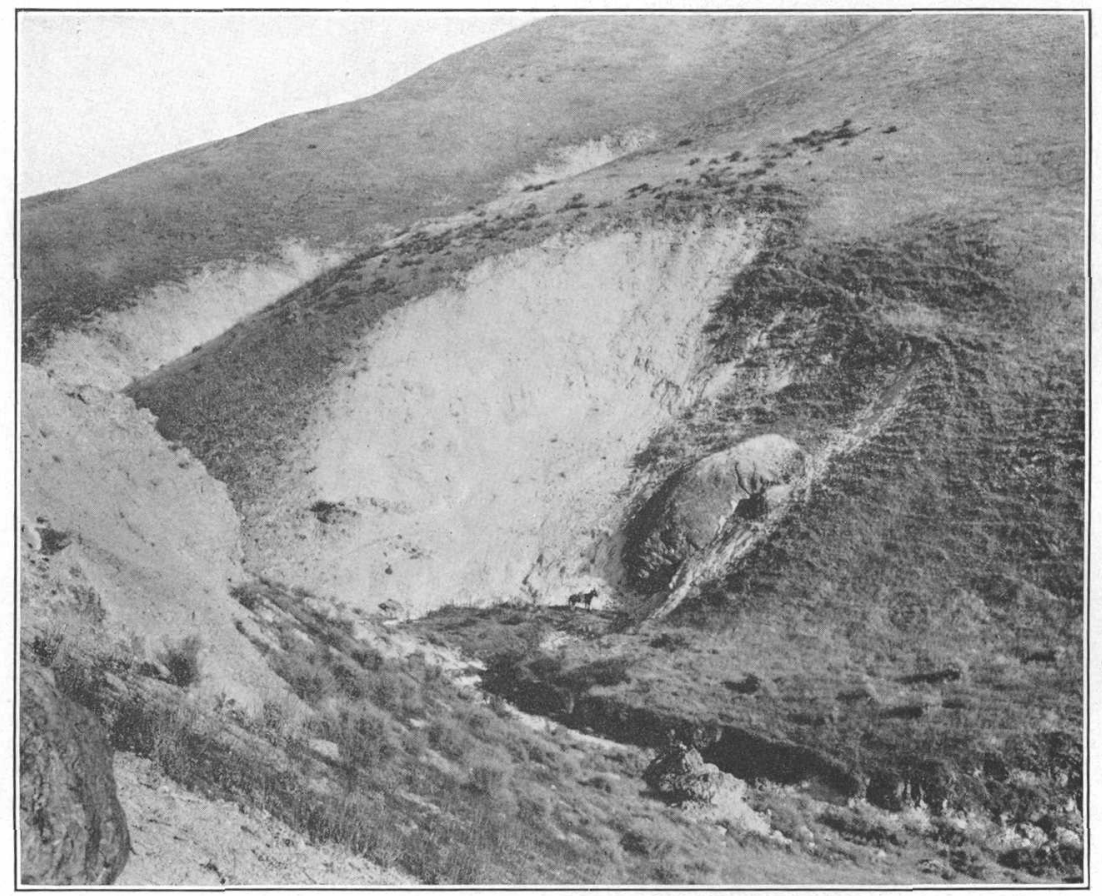

B. HUGE SERPENTINE BOWLDERS IN THE BIG BLUE MEMBER ON MARTINEZ CREEK. 
Hunt, of the United States Geological Survey. This analysis shows that the coating is composed mainly of silica, alumina, and ferric iron and that it contains no phosphoric acid. The coating is so thin that it is difficult to obtain a sample large enough for analysis and free from impurities. It is possible that the alumina and the iron are really derived from the grains and not from the coating. The coating can not, however, be vivianite, as was suggested in the Coalinga report. ${ }^{1}$ Many of the grains are volcanic rocks that contain phosphate probably as apatite. The analysis noted in the Coalinga report was made by digesting with acid a part of the same sample as that analyzed by Mr. Hunt. The phosphate obtained was evidently derived from the grains themselves, not from the coating.

A blue color due to the same cause is common in this and other parts of the Coast Ranges in the San Pablo, Etchegoin, and Jacalitos formations, and has also been noted locally by the writers in the sandstones bedded with the Kreyenhagen shale. This color has been considered by some as characteristic of the San Pablo formation and as a criterion for correlating beds with that formation. The discovery of exactly similar bluish sand in the lower part of the Miocene, lying stratigraphically many hundred feet below the bluish sandstone in the upper Miocene in the same region, shows that this, like many other lithologic features, is entirely unsafe as a basis of correlation in the Coast Ranges.

BigBlue serpentinous member.-The upper member of the Vaqueros, locally known as the Big Blue, and in this report called the Big Blue serpentinous member, is formed largely of small flakes of serpentine which make up a fine-grained, compact, tough shale, slightly bluish when fresh but weathering to various shades of red, yellow, and brown, owing to oxidation of the iron. Locally this shale becomes sandy by the addition of grains of various quartzose rocks, but through most of its extent it is remarkable for being little else than a compacted mass of serpentine dust, flakes, and pebbles. With this shale are conglomerates formed almost entirely of serpentine bowlders, the largest of which are huge blocks many feet in diameter. This member is first definitely recognizable on the south in the northern part of the Coalinga oil field. Many of the wells in this part of the field penetrate at least 500 feet of the serpentinous beds. Northward from this locality to a point about 2 miles beyond the Domengine ranch the Big Blue varies in thickness from 40 to 200 feet. Still farther north it rapidly thickens, and between Martinez and Cantua creeks it forms practically the whole of the Vaqueros, having a thickness of about 1,000 feet on Salt Creek, where little if any sandstone and shale separate it from this diatomaceous Kreyenhagen shale below. The lens 
decreases in thickness from Salt Creek northwestward and terminates northeast of Ciervo Mountain, its total extent being about 20 miles. The weathered surfaces of this member are not unlike the outcrops in the serpentine areas on the summit of the range 10 to 15 miles to the west, and the large bowlders half buried in the fine dust of weathered serpentine flakes resemble outcrops of serpentine in place. This appearance has led some observers to believe that these rocks are intrusive in the Tertiary formation and to conclude that the occurrence of such igneous masses has spoiled any chances for the accumulation of oil in this region. The sedimentary nature of the beds is unquestionable, however, and the material forming them must have been weathered and transported from a near-by land mass of serpentine, which was almost certainly that on the summit of the range south of New Idria. An inspection of the geologic map (Pl. I) will show the relatively small extent of the Big Blue and its close geographic relation to the serpentine at the crest of the range. Typical exposures of the Big Blue are shown in Plate XI.

The Big Blue is nonfossiliferous in the Coalinga district, and its stratigraphic relations to the underlying and overlying formations are not altogether clear. In the report on that district ${ }^{1}$ it was tentatively regarded as the basal part of the Santa Margarita (?) formation, although its possible equivalence to a portion of the Vaqueros or of the shale of the Monterey group was stated. Typical Vaqueros fossils occur, however, at several points in the Ciervo and Big Blue hills in sandy beds interstratified with or overlying the serpentinous beds of the Big Blue, showing that the latter are really a part of the Vaqueros.

AREA IN THE VALIECITOS.

A belt of Vaqueros rocks encircles The Vallecitos and extends for an undetermined distance to the west on both the north and south sides of the valley of Pimental Creek. On the south side of The Vallecitos the dips are steep, in places slightly overturned, and the belt of outcrop varies in width from about one-fifth to half a mile. On the north side the Vaqueros is in places tilted to angles of $50^{\circ}$ or $60^{\circ}$, but through much of the distance, especially at the east end of The Vallecitos, the dips are rather low, and the belt formed by these rocks is in places over a mile across. Locally isolated areas of the Vaqueros occur also, resting on the Eocene and Cretaceous formations, toward the central part of the Griswold Hills. The formation differs somewhat from the equivalent succession of beds exposed along the foothills bordering the San Joaquin Valley, owing to the presence here of considerable masses of diatomaceous shale, which locally constitute almost a third of the total thickness. This organic material ranges from white earthy shale, stained slightly pinkish 
(probably by oil) to thin-bedded or platy hard siliceous and calcareous shale. It is nearly identical in character with the Kreyenhagen shale, and its presence makes it difficult to draw the line between the two formations.

Along the south side of The Vallecitos the formation has an average thickness of about 900 feet and is pretty constantly separable into two main divisions-one of sandstone and sandy shale forming roughly the lower two-thirds and one of siliceous diatomaceous shale forming the upper third. In places this division might be made threefold, with sandstone at the base, siliceous shale at the top, and an intermediate division about equal in thickness to the other two, of interbedded massive, rather incoherent sandstone, shaly sandstone, and impure siliceous shale. The sandstone is mostly gray when fresh, but weathers yellowish. It is variable in character and locally conglomeratic. Fossils are in places very abundant, especially in the lower beds, which form prominences on all the ridges which they cross. The siliceous shale is hard, brittle, and usually whitish or purplish. It forms the top of the Vaqueros along the south side of The Vallecitos in contact with the overlying upper Miocene clayey beds.

On the north side of The Vallecitos the Vaqueros varies in thickness from 700 or 800 feet at the east end of the valley to more than $-1,400$ feet near the west end. The upper part of the formation, comprising perhaps one-half of the whole, is composed of arkose gray sandstone much like that which forms the lower member of the Vaqueros in the Ciervo Hills. These sandstones are diverse in grain and in degree of induration. Some are very feebly coherent and weather easily to loose sand; others are indurated by a calcareous cement derived from the fossil shells they contain and weather to prominent outcrops. The hard beds are especially prominent about 2 miles northeast of Griswolds, where they form a narrow ridge dividing Cedar Flat from The Vallecitos. The central part of the formation, comprising in places about one-third of the whole, is composed largely of diatomaceous shale with various interstratified beds of sandy clay, shale, and sandstone. The lower part is formed of fossiliferous gray sandstone, usually somewhat finer grained than the upper sandy part and, unlike that part, containing but few hard, prominent-weathering calcareous beds. The division outlined above is rather arbitrary, for the several members grade into one another and it is impossible to make any sharp separation. Moreover, in places, notably at the east end of the valley, the basal part of the formation is composed of diatomaceous shale almost identical with the Kreyenhagen shale upon which it rests and the two formations are separated with difficulty. The upper beds are sandy along the entire north side of The Vallecitos and are readily separable from the 
overlying clay and gravel. The variability of the zones in this formation is illustrated by the fact that along the north side of the valley the upper beds are sandstone, shale of organic origin occurring there only in the lower part of the formation.

The following section of the Vaqueros was measured in the northeast corner of The Vallecitos:

Section of the Vaqueros formation in the northeast corner of The Vallecitos, north of the New Bedford well.

Upper Miocene not exposed.

Feet.

Upper reef bed. Soft gray sandstone, slightly conglomeratic in places and much cross-bedded; weathers to loose brownish sand. Lower 100 feet very fossiliferous, hard, and weathering out prominently. Turritella ocoyana and Scutella merriami especially abundant..................................

These beds form the crest of the ridge north of the New Bedford well. Some 2 to 3 miles west of this place about 100 to 150 feet of sandstone of the Vaqueros formation overlies the uppermost Vaqueros exposed in this section and underlies the upper Miocene clay.

Soft gray sandstone like that at top of section, becoming gradually more shaly toward the base........................

Thin-bedded sandstone alternating with sandy carbonaceous shale, white to purplish brown in color..................

Lower reef bed. Massive gray sandstone, mainly fine grained, but containing a few pebbly layers with cobbles as much as 8 inches in diameter. Weathers out prominently from the softer sands. Much cross-bedded and hardened by iron along irregular lines. Lower 30 feet very fine grained blue-gray sandstone containing abundant specimens of Tivela inezana........ 100

Soft fine-grained gray sandstone, gradually becoming more shaly toward the base and forming a gradation between the reef sandstone above and the shale below. Fossils abundant in calcareous nodules 20 feet above the base......................

Diatomaceous shale with a small amount of bedded sandstone and a few calcareous layers. Upper part from 20 to 85 feet thick, soft and almost earthy, very diatomaceous, and of marked pinkish color. Lower part of dark-brownish color, hard, thin bedded, and brittle, and contains numerous calcareous layers which are usually fossiliferous. Becomes sandy toward base, grading into sandstone below......................... 175

Fine gray sandstone with some shale and locally a fine conglomerate with pebbles as much as 1 inch in diameter. Lower part a fine greenish-gray sand with chocolate-brown fossiliferous layers. Rests unconformably upon underlying diatomaceous Kreyenhagen shale................................ $50_{ \pm}$

AREA NEAR LLANA.DA.

South of Llanada a formation partaking of the same general character as the Vaqueros in The Vallecitos, and containing a similar fauna, is exposed in a small faulted syncline south of Llanada in the 
foothills bordering the south side of Panoche Valley. This formation rests unconformably on the Cretaceous and has a thickness of at least 600 feet. It is formed of fine-grained shaly sandstone, massive cross-bedded sandstone, a little clay or clay shale, and two or more irregular beds of white diatomaceous shale. The upper and thicker one of these white shale beds is about 50 feet thick and is unusually pure diatomaceous material. The Vaqueros is overlain by not less than 500 feet of tuffaceous sand and vesicular basalt, which is in turn overlain by at least 200 feet of gritty, loosely aggregated sandstone and gravel of much the same character as the fossiliferous sandstone underlying the basalt. There is no definite evidence concerning the age of the upper two members in this section, but it is believed probable that the beds of tuff and vesicular basalt which overlie the fossiliferous clastic beds of the Vaqueros are also of lower Miocene age, and that they were formed at the same time as the beds in the upper part of the Vaqueros in The Vallecitos. The overlying coarse sandstone and gravel which appear along the axis of the syncline may be either a part of the Vaqueros or younger. For the present they are mapped as undifferentiated Miocene.

RELATION TO PETROLEUM.

In the Coalinga district the Vaqueros formation constitutes the reservoir from which most of the wells in the Eastside field along the Coalinga anticline and many ${ }^{\circ}$ of those farther west derive their oil. The oil is believed to enter the formation from the underlying diatomaceous Kreyenhagen shale. It collects in certain favorable zones, chiefly near the base, although locally permeating the whole formation up to the base of the Big Blue member in lesser amounts. North of the Coalinga district the Vaqueros almost everywhere overlies the Kreyenhagen shale, and wherever the structure is favorable it would be expected to absorb any oil that might rise from that shale, just as in the Coalinga district. Therein lies its chief importance in connection with the problem of possible oil occurrence in this region.

In addition to the Kreyenhagen shale, another possible source of oil in the Vaqueros formation is the diatomaceous shale which it contains around The Vallecitos. Should this interbedded shale be the source of any oil, the sandy beds of the formation would probably act as the reservoir in which the oil would collect. The aggregate volume of the diatomaceous shale in the Vaqueros, however, is not comparable with that of the Kreyenhagen shale, and it is doubtful whether it is of any great importance in this connection.

In most of the region the Vaqueros contains no indications of oil and may safely be said to be barren of it. Around the borders of The Vallecitos, however, signs of oil appear in it at the surface. The actual occurrences of petroleum in this formation are discussed more fully elsewhere in this report (pp. 133-135). 


\section{UNDIFFERENTIATED MIOCENE.}

Fossiliferous sand, clay, and gravel of marine origin, whose exact stratigraphic position is not definitely known, occur in two small areas, one in the region about Tesla and the other between Garzas and Crow creeks. In the hills south of Llanada is another small area of sand and gravel whose age is not definitely known. The rocks in these three areas have been shown on the geologic map as undifferentiated Miocene.

\section{AREA NEAR TESLA.}

In the extreme north end of the region a body of marine sedimentary beds, having a maximum thickness of at least 700 feet, rests unconformably upon the Cretaceous and Eocene formations and is overlain with possible unconformity by the bluish sandstone that constitutes the.San Pablo formation. These beds are mainly coarsegrained or gritty fossiliferous arkose gray sandstone and fine-grained gray clayey sandstone, with irregular lenses of conglomerate and a little interstratified clay or clay shale. They are well developed in the area mapped by the Survey as the Tesla quadrangle, but hardly appear south or east of that area. As the writers' investigation in the Tesla area was only in the nature of a reconnaissance, sufficient time could not be taken to work out the exact stratigraphic relations of these beds. They are of Miocene age, as shown by the fossils they contain, but their exact relation to the overlying San Pablo formation or to the Santa Margarita (?), Jacalitos, and Etchegoin formations in the southern part of the region under discussion is not definitely known. In dip and strike they appear perfectly conformable with the overlying beds that are described as the San Pablo formation. In places, however, the bluish sandstone of the San Pablo overlaps the fossiliferous Miocene beds rather abruptly and rests upon the Cretaceous and Eocene rocks. This relation is probably best shown between Patterson Pass and Midway, on the east flank of the Altamont anticline. The evidence obtained in the field is insufficient to determine whether this overlapping is due to an unconformable relation existing at the base of the blue sandstone or simply to a transgressive movement of the sea throughout the period during which both this fossiliferous gritty sandstone and the blue beds of the San Pablo were being laid down. The sandstone may be a part of the San Pablo formation, as it was regarded by Weaver, ${ }^{1}$ or it may constitute a distinct and older formation. It may be approximately the equivalent of the beds in the southern part of the region that are here described as the Santa Margarita (?) formation. For the present it will be discussed separately from the San Pablo and

i Weaver, C. E., Stratigraphy and paleontology of the San Pablo formation in middle California: Callfornia Univ. Dept. Geology Bull., vol. 5, p. 256, 1909. 
called undifferentiated Miocene, inasmuch as it forms a distinct and easily recognizable unit and one that can not be definitely correlated with any other recognized formation.

The beds comprised in the undifferentiated Miocene cover a considerable area between Corral Hollow Creek and Livermore Pass, where they form a broad belt swinging about the nose of the plunging Altamont anticline, which trends in a northwesterly direction through the hills near Altamont. They also continue to the south and southeast as a broken and irregular sheet to a point about $1 \frac{1}{2}$ miles northwest of Carnegie, east of which they are covered by the bluish beds of the San Pablo formation. Northwest of Greenville, on the west flank of the Altamont anticline, these beds continue into the foothills on the southwest side of Mount Diablo, whereas on the east flank of that fold, about a mile north of the rock cut on the Southern Pacific Railroad 2 miles northwest of Midway, they are overlapped by the blue sandstone of the San Pablo formation. They are also exposed in a narrow belt of outcrop less than 1,000 feet wide from a point about half a mile northeast of Tesla westward for some 3 miles, nearly to the edge of Livermore Valley. Small areas between Corral Hollow and Lone Tree creeks are formed by strata which are probably the equivalent of these north of Tesla already described. It is also possible that part of the beds between Corral Hollow and Lone Tree creeks tentatively mapped as Tejon may be of Miocene age.

In the Tesla region the undifferentiated Miocene has a thickness of not less than 700 feet. It is formed mainly of rather incoherent coarse white arkose sandstone, somewhat cross-bedded and, where massive, containing small ellipsoidal concretions. With this gritty sandstone are irregular beds and lenses of conglomerate composed of fairly well rounded pebbles of various quartzose and igneous rocks. Locally fragments of red chert are abundant. In places the sand is very fine, slightly greenish gray, and filled with fossils. True shaly beds are rare, and greenish clay forms a small part of the section. Carbonaceous material is fairly abundant, occurring most noticeably in the finer sand and clayey beds, to which it gives in places a pinkish-brown color. In general these beds resemble the Tejon (upper Eocene) rather closely and where in contact with that formation are separated only with difficulty. They contain typical Miocene fossils, however, specimens of the large oyster Ostrea titan being especially abundant and weathering out on the surface in large numbers.

AREA BETWEEN GARZAS AND CROW CREEKS.

The undifferentiated Miocene between Garzas and Crow creeks outcrop in a narrow belt about 8 miles in length close to the outer edge of the low terraced foothills. It is composed mainly of very fine grained gray-white sandstone, very micaceous, carbonaceous, as a 
rule poorly consolidated, but in places showing thin bedding. In places, owing either to the finely disseminated carbonaceous material or to a trace of iron oxide, the beds assume a pinkish or even purplish tinge. Fossil mollusks occur sparingly, but impressions of leaves and other vegetable material are abundant. These beds resemble rather closely the fine-grained clayey sandstone of the Tejon formation underlying the Kreyenhagen shale in this same locality. They weather easily, furnishing but poor exposures, and are largely covered by a mask of terrace gravel, so that it is difficult to determine either their character or their relation to the underlying shale. As nearly as can be estimated their maximum thickness is about 400 feet, but the exposed thickness is greatly reduced through most of the belt owing to the unconformable overlapping of the San Pablo formation.

The undifferentiated Miocene rests unconformably upon the Kreyenhagen shale and, in the lower part, contains fragments of diatomaceous shale derived from that formation. It is overlain unconformably by the San Pablo, as shown by the abrupt manner in which it is overlapped by the tuffaceous and pebbly strata of that formation. The stratigraphic equivalent of this formation is not known. It may be the equivalent of the Vaqueros, or the Santa Margarita (?) in the southern end of the region, or the undifferentiated Miocene near Tesla. The fact that it is described under the same heading with the last-mentioned formation should not be understood to mean that the writers wish to suggest such a correlation.

AREA NEAR LLANADA.

The small area mapped as undifferentiated Miocene along the axis of the small syncline in the hills south of Panoche Valley has already been mentioned in the description of the Vaqueros formation. The beds so mapped are composed of sandstone and conglomerate which have a thickness of at least 200 feet. They rest upon a succession of beds of vesicular basalt, ashy and tuffaceous material, which in turn overlie the fossiliferous sandstone of the Vaqueros formation (lower Miocene). As has already been stated it is believed probable that both the basaltic and tuffaceous beds and the overlying gravel and sand are of lower Miocene age, but in the absence of definite evidence the three members of the section are mapped separately.

\section{RELATION TO PETROLEUM.}

On the Hamilton ranch, about 3 miles northwest of Tesla, the undifferentiated Miocene rests upon clay shale and sandstone of Cretaceous age, and the basal beds are saturated with petroleum. The Cretaceous beds exposed here may be part of the Panoche or of the Moreno formation. The oil is believed to have originated either in the dark clay shale that immediately underlies the undifferentiated 
Miocene or, more probably, in the siliceous shale of the Moreno formation, which is exposed near Tesla and which probably underlies the Tertiary beds where they occupy the trough of the irregular syncline between Tesla and the Hamilton ranch. The latter hypothesis implies the perfectly natural supposition that the oil has migrated from the shale in which it formed, passing along the contact of the Cretaceous and overlying beds, and lodged in the porous Miocene sandstone. In other portions of the region north of Lone Tree Creek, where the structure is favorable and where these Miocene beds rest upon the siliceous shale of the Moreno formation or upon Cretaceous beds not too far removed from it, they might serve as a reservoir for oil formed in the shale.

Between Garzas and Crow creeks the beds described as undifferentiated Miocene rest upon the Kreyenhagen shale, in which most of the petroleum found in the Coalinga field originated. As they are more porous than that shale they might be expected, where the structure is favorable, to act as a reservoir for any oil which may have formed in the underlying shale. No surface evidence was discovered that these beds contain oil, but the structure in the region in which they are exposed is not entirely unfavorable to the supposition that they might contain it at depth.

South of Llanada the undifferentiated Miocene occupies the basin of a small syncline. It rests directly upon volcanic flows or tuffs or upon detrital beds formed largely of fragments of igneous rocks and is stratigraphically many hundred feet removed from strata in which it seems reasonable to suppose petroleum may have originated. It is therefore believed to have in this area no important relation to the occurrence of petroleum.

The occurrence of oil in the undifferentiated Miocene near Tesla and its possible occurrence in the undifferentiated Miocene near Orestimba Creek are discussed in more detail in another portion of this report (pp. 184-194).

\section{SANTA MARgARITA (?) FORMATION (MIDDLE MIOCENE).}

AREAL EXTENT AND STRATIGRAPHIC RELATIONS.

Along the edge of the San Joaquin Valley between Joaquin Ridge and Arroyo Ciervo the Vaqueros formation is overlain by beds of conglomerate, coarse to fine grained arkose sandstone, and fine gritty clay, which contain a marine fauna. These beds are the northward extension of those mapped in the report on the Coalinga district as the Santa Margarita (?) formation (upper middle Miocene) and tentatively correlated with the Santa Margarita formation on the western slopes of the Coast Ranges, except that in the Coalinga report the beds locally known as the Big Blue are included in the Santa Margarita(?) formation, and in this report they are included in the Vaqueros 
formation, because they have here been found to contain a typical Vaqueros fauna. In the Coalinga district no fossils were obtained from the Big Blue member. In the present report these beds will be termed the Santa Margarita(?) formation to show their equivalence (with the exception of the Big Blue member) to the beds so designated in the Coalinga region.

The Santa Margarita (?) is known only in the south end of the region under discussion, along the edge of the San Joaquin Valley. It is not present in The Vallecitos, nor, so far as known, along the edge of the San Joaquin Valley north of Arroyo Ciervo, unless the fossiliferous Miocene beds which occur near Tesla beneath the bluish sandstone of the San Pablo formation or the gray sands near Orestimba Creek, both of which are described as undifferentiated Miocene, are its equivalent.

In the north end of the Coalinga district, between Joaquin Ridge and the south line of T. 18 S., the belt of outcrop of the Santa Margarita (?) formation is about three-quarters of a mile wide. North of that locality the outcrop narrows abruptly, owing both to a steepening of the dip and to a thinning of the formation. Despite the fact that the Santa Margarita(?) formation is not thick, it forms a very prominent feature of the landscape in this part of the region, for many of the beds embraced in it weather to prominent and easily recognizable outcrops. Near Joaquin Ridge hard calcareous beds filled with large oyster shells form prominent strike ridges with characteristic saw-tooth cross section, and north of Cantua Creek the basal conglomerate forms prominent buttes and cliffs, in places over 100 feet high.

The Santa Margarita (?) rests unconformably upon the Vaqueros. In much of the region, however, it is difficult to make an accurate separation of these two formations, for the upper beds of the Vaqueros and the lower beds of the Santa Margarita (?) are formed largely of similar materials. Their separation is especially difficult where both formations contain a large amount of serpentine detritus, as they do north of Cantua Creek. In the vicinity of Cantua Creek and Arroyo Hondo a distinct erosional unconformity separates the two formations. The evidence of this unconformity has been more fully discussed in the description of the Vaqueros formation. The Santa Margarita (?) appears to be conformable with the overlying strata so far as measurable discordance in dip or strike is concerned. In the Coalinga district the base of the overlying Jacalitos formation was mapped as the base of a conglomerate filled with fossil wood which lies about 400 to 500 feet stratigraphically above the top of the uppermost bed containing Santa Margarita (?) fossils. North of Joaquin Ridge this line falls at the base of a zone of alternating beds of blue sandstone and reddish and greenish clays. As this line is followed northward 
the exposed thickness of the underlying strata mapped as the Santa Margarita (?) formation gradually lèssens, and these beds disappear near Arroyo Ciervo, apparently as a result of transgression of the overlying formation. This apparent overlapping is also shown near Oil Canyon and was considered as proof of an unconformity between the Santa Margarita (?) and Jacalitos there. ${ }^{1}$

\section{LITHOLOGY AND THICKNESS.}

The lower part of the Santa Margarita (?) is coarse, varying from a fine pebbly sandstone less than 10 feet thick to a mass of large serpentine bowlders over 50 feet thick. This bowlder bed is overlain by fine-grained to slightly pebbly sandstone which has a maximum thickness near Joaquin Ridge of about 420 feet. This sandstone is very fossiliferous, both at the top and near the bottom. Near the bottom several hard calcareous beds filled with large oyster shells and containing numerous specimens of the large barnacle Tamiosoma gregaria weather out as "reefs" and form the steep east face of the Big Blue Hills near Domengine Creek. At the top of this zone the large shells characteristic of the calcareous reef-like beds are less plentiful, but a great number of species of other fossil mollusks occur. These fossiliferous beds are the uppermost that can be unquestionably assigned to the Santa Margarita (?) formation, for the overlying beds here included in the formation, about 400 feet in thickness, are composed of soft brownish, somewhat concretionary sandstone without fossils and may belong to the overlying Jacalitos formation. The Santa Margarita (?) formation attains its greatest development in the north flank of Joaquin Ridge, where its thickness is about 850 feet. On Cantua Creek, about midway between. Joaquin Ridge and Arroyo Ciervo, where the Santa Margarita (?) disappears, it is only about 70 feet thick.

\section{RELATION TO PETROLEUM.}

In the Coalinga anticline field the upper limit of the productive oil measures is determined by the impervious strata forming the Big Blue member of the Vaqueros formation, no oil having collected in commercial quantity either in or above that member. In the Westside or Coalinga syncline field the Santa Margarita (?) formation constitutes part of the productive zone, owing to a progressive southward overlap of higher and higher beds upon the Kreyenhagen shale.

Along the edge of the San Joaquin Valley northward from Joaquin Ridge the Santa Margarita (?) rests upon the Big Blue member and is separated from the Kreyenhagen shale by several hundred feet of sandstone belonging to the Vaqueros formation. Thus the same conditions exist here as in the Eastside or anticline field at Coalinga, and here, as in that field, the Santa Margarita (?) formation has no direct 
relation to the occurrence of petroleum other than that of constituting additional strata through which it would be necessary to drill in order to reach the possible oil-producing strata below.

\section{JACALITOS AND ETCHEGOIN FORMATIONS (UPPER MTOCENE AND PLIOCENE ?).}

\section{DISTRIBUTION AND STRATIGRAPHIC RELATIONS.}

Sedimentary beds comprising mainly bluish and brownish sandstone, reddish and greenish gritty clay shale, and slightly coherent conglomerate form the northward extension of the Jacalitos and Etchegoin formations as mapped in the Coalinga district and are traceable through the foothills bordering the San Joaquin Valley as far as Tumey Gulch, near which they are abruptly overlapped by younger formations. These beds are probably to a large extent marine deposits but are in part fluviatile or lacustrine. They dip $15^{\circ}-30^{\circ} \mathrm{E}$. and form a belt of rolling hills averaging about $1 \frac{1}{2}$ miles in width. This belt is separated from the San Joaquin Valley by a zone of low hills, between half a mile and a mile in width, formed of poorly consolidated beds that are tentatively correlated with the Tulare formation of the Coalinga district. Beds equivalent to a portion of the Jacalitos and Etchegoin formations occupy the trough of the Vallecitos syncline, forming the floor of The Vallecitos and a narrow zone of foothills on either side. The total width of this belt ranges from about $1 \frac{1}{2}$ miles to more than 3 miles. From the vicinity of Tumey Gulch northward to and beyond Little Panoche Creek the late Miocene beds are covered by the younger terrace deposit and alluvium. As it is thus impossible to trace. the Jacalitos and Etchegoin formations (upper Miocene and Pliocene?) in the south end of the region into a connection with the San Pablo formation (upper Miocene) in the north end, the correlation of those formations must rest largely if not entirely upon the fossils they contain. Fossils are rare both in the Jacalitos and Etchegoin and in the San Pablo in the region under discussion, and the correlation of these formations must rest largely upon fossils which have been collected outside the region. For the present the Jacalitos and Etchegoin will be discussed separately from the San Pablo, although they are believed to be in part at least synchronous. It was found impossible, moreover, to differentiate the Jacalitos and Etchegoin formations, as was done in the Coalinga district, for that separation was accomplished by the mapping of faunal zones.

Along the foothills bordering the San Joaquin Valley the beds composing the Jacalitos and Etchegoin formations rest with probable unconformity upon the Santa Margarita (?) formation as far north as Arroyo Ciervo, north of which they overlap the Vaqueros. The evidence of the unconformity at the top of the Santa Margarita (?) 
has been discussed in the description of that formation. In The Vallecitos the formation that is considered as the equivalent of the Jacalitos and Etchegoin formations rests upon the Vaqueros with no evidence of unconformity so far as visible discordance in dip and strike is concerned. However, the lack of any strata here that might be considered as the equivalent of the Santa Margarita (?) formation which appears along the edge of the San Joaquin Valley but a few miles to the east shows that the line separating the upper and lower Miocene strata in The Vallecitos must mark a considerable break in sedimentation. No evidence indicative of an unconformity between the Jacalitos and Etchegoin formations and the overlying. Tulare (?) was obtained and the separation of the Tulare (?) from the older formations is for the most part arbitrary and rather indefinite. It is believed probable that the beds from the base of the Jacalitos to the top of the Tulare (?) were formed during a single period of deposition.

\section{LITHOLOGY AND THICKNESS.}

Along the foothills of the San Joaquin Valley the Jacalitos and Etchegoin formations are composed of thin-bedded to massive and cross-bedded bluish and brownish sandstones, with numerous pebbly lenses, reddish and greenish clays, or clay shale, and a few beds of coarse gravel. Some of these beds, particularly the bluish sandstone, are firmly consolidated, but others are little more coherent now than when they were originally laid down. The peculiar bluish color of the sandstone is probably the most prominent feature of the beds, but, as has been shown, it is not characteristic of the upper Miocene formations alone, being well shown by the Vaqueros (lower Miocene). It therefore can not be taken as a safe criterion upon which to base any extensive correlation. Near Joaquin Ridge the combined thickness of the Jacalitos and Etchegoin formations is about 3,300 feet. Bluish sandstone forms the most characteristic feature of the beds here, weathering out into rather prominent outcrops and determining low strike ridges. It is especially prominent near the central part of the section-that is, near what corresponds with the base of the Etchegoin formation as mapped in the Coalinga district. The upper part is formed largely of fine clayey sand and clay with a very few beds of gravel. Northward from the Domengine ranch the bluish sandstone becomes gradually less prominent, disappearing from the lower part of the section but forming rather inconspicuous beds in the upper part as far north as Tumey Gulch. North of Cantua Creek the strata are more uniformly fine grained than they are near Joaquin Ridge, being formed largely of alternating beds of reddish and greenish clay with beds of fine-grained sandstone and a few irregular lenses of gravel. The hills north of Cantua Creek formed by the beds in the lower part of the section present a peculiar banded appearance, owing S1281 ${ }^{\circ}-$ Bull. $603-15-7$ 
to the alternation of zones of red and green clay. This effect is particularly noticeable on the steeper westerly slope of the strike ridges, and, although the exposures are poor and the hills are covered by loose soil, the vegetation is so scanty that the effect is visible at a considerable distance.

In The Vallecitos the Jacalitos and Etchegoin formations occupy the trough of the syncline which determines the valley, and their aggregate thickness is not less than 2,800 feet west of John Ashurst's ranch house. Eastward from this place the syncline flattens, and a large part of these formations has been removed by erosion. The greater part of the beds here is formed of reddish and greenish, somewhat gritty clay, which is easily eroded and forms low rounded hills that present the same peculiar banded appearance noticeable in the lower part of the Jacalitos and Etchegoin formations along / the foothills east of Ciervo Mountain. Interbedded with the clay is a minor amount of fine-grained greenish-gray sand, locally hardened and forming poorly stratified and cross-bedded sandstone which in places contains small dark-brown concretions. Small lenses of poorly sorted gravel also occur. No trace of bluish sandstone was seen. These beds closely resemble and are believed to be the equivalent of the lower part of the succession of strata forming the Jacalitos and Etchegoin formations along the foothills of the San Joaquin Valley.

RELATION TO PETROLEUM.

Beds belonging to the Jacalitos and Etchegoin formations are known to contain petroleum at but a single locality in the area shown on the map (Pl. I). This occurrence, in the western part of The Vallecitos, is unique and is discussed in detail on page 135. Except in this area these formations are believed to be nonpetroliferous north of the Coalinga district. Like the Santa Margarita (?) formation, however, they overlie the beds which in certain portions of the field may contain petroleum, and their thickness in any region is an important factor which must be considered in determining the accessibility of possible oil-producing beds.

\section{SAN PABLO FORMATION (UPPER MIOCENE).}

GENERAL CHARACTER.

In the vicinity of Tesla, resting upon the undifferentiated Miocene, and southward as far as Little Panoche Creek, overlapping the older Tertiary or Cretaceous strata, is a formation composed mainly of bluish sandstone, fine and coarse grained tuffaceous sand, clay, and beds of conglomerate and conglomeratic sand. These strata are mainly marine deposits but are in part of lacustrine or fluviatile origin. They may be traced more or less continuously from the Tesla region northward along the edge of the San Joaquin Valley to the north side of Mount Diablo, where they have been more thoroughly 
studied and definitely correlated with the San Pablo formation on San Francisco Bay. ${ }^{1}$ They are therefore described in the present report as the San Pablo formation. Their relation to and probable correlation with at least a portion of the Jacalitos and Etchegoin formations have already been mentioned in the description of those formations.

\section{DISTRIBUTION.}

North of Corral Hollow, as far west as the line between Alameda and San Joaquin counties, this formation dips at irregular low angles, prevailingly toward the San Joaquin Valley, and forms practically all the foothills. Northward from the Southern Pacific Railroad to and beyond the edge of the region examined it forms all of the foothill area bordering the San Joaquin Valley. West of Carnegie it occupies the trough of the irregular and closely folded syncline that passes about a mile north of Tesla. Between Corral Hollow and Lone Tree creeks it occupies the trough of the irregular and faulted syncline inclosed in the foothills, and also a narrow belt a few hundred feet in width on the east side of the fault that passes through the low hills near the edge of the plain.

Southward from Lone Tree Creek beds which represent a portion of the San Pablo as exposed in the Tesla area are traceable for about 30 miles, nearly to Garzas Creek, where they disappear beneath the alluvium of the San Joaquin Valley. Beds of a somewhat similar character, occupying a similar stratigraphic position, appear at the edge of the low foothills between Ortigalito and Little Panoche creeks. Between Lone Tree and Salado creeks the San Pablo occupies a belt only a few hundred feet in width, but to the south, between Salado and Orestimba creeks, owing to a flattening of the dip it forms somewhat more of the surface.

\section{STRATIGRAPHIC RELATIONS.}

Near Corral Hollow the blue sandstone rests with seeming conformity in dip and strike upon the coarse white fossiliferous sandstone, gravel, and clay which have already been described as undifferentiated Miocene. The relation of the bluish sandstone of the San' Pablo formation to the underlying Miocene is thought to be one of nonconformity, but more evidence on this point is necessary before a definite conclusion can be reached. It is possible that the beds discussed as undifferentiated Miocene may be part of the San Pablo formation, and they were so regarded by Weaver. This relationship is discussed more in detail in the description of the undifferentiated Miocene. South of Lone Tree Creek the San Pablo is everywhere unconformable with the underlying strata and in different places rests

\footnotetext{
1 Weaver, C. E., Stratigraphy and paleontology of the San Pablo formation in middle California: California Univ. Dept. Geology Bull., vol. 5, p. 252, 1909. Clark, B. L., The Neocene section at Kirker Pass, on the north side of Mount Diablo: Idem, vol. 7, pp. 47-60, pl. 7, 1912.
} 
upon the Moreno formation (Upper Cretaceous), the Tejon formation (upper Eocene), the Kreyenhagen shale (Oligocene?), and between Garzas and Orestimba creeks upon gray sandstone mapped as undifferentiated Miocene. It is overlain by a heterogeneous assemblage of beds of poorly stratified, rather incoherent gray-brown sandstone and coarse, ill-sorted gravel which is considered as probably the Tulare formation. This formation appears to be perfectly conformable with the underlying San Pablo both in dip and strike, and also to show a gradation in lithologic character into the San Pablo. It is believed probable that the San Pablo and the Tulare (?) were formed during an uninterrupted epoch of sedimentation and that the gravel beds are perfectly conformable upon the underlying bluish sandstone. Southward from Lone Tree Creek the San Pablo continues in a very narrow belt, usually less than 300 feet thick, for at least 30 miles and probably for 60 miles if the correlation of the beds in the hills between Ortigalito and Little Panoche creeks is correct. It seems improbable that were these beds separated from the overlying beds by an unconformity they would continue this distance with so constant a thickness.

\section{IITHOLOGY AND THICKNESS.}

North of Lone Tree Creek the San Pablo has a thickness of not less than 700 feet. In general character this formation is very similar to the Jacalitos and Etchegoin formations in the Coalinga region. Near the base of the formation the beds are massive, cross-bedded, coarse to fine grained bluish sandstone interstratified with light-buff clayey material. The lower massive sandstone is well exposed on the hills west of Alder Spring; along the north side of Corral Hollow near Pottery, where it stands almost vertical and weathers out to prominent outcrops; and north of Carnegie, where it dips at a low angle and has been deeply dissected by the small streams, forming box canyons. Beds of heavy conglomerate are numerous and in places form most of the strata for a thickness of several hundred feet. These are, however, lenticular and do not continue for any great distance. The fragments forming them are almost wholly well-rounded volcanic rocks, some of them tuffaceous, but mostly nonvesicular, medium acidic porphyritic rock of andesitic character. The conglomerate is particularly noticeable near the place where Corral Hollow empties into the San Joaquin Valley, there forming the cliff locally known as Castle Rock. Near the top the beds are finer grained and more clayey and lose much of the bluish color characteristic of the massive sandstone. The upper beds weather easily and form low rounded clayey hills that afford but few exposures.

Although the outcrop of the San Pablo formation is traceable as a narrow zone for many miles southward from Lone Tree Creek, it comprises beds of diverse lithologie character. Moreover, the characters of the same beds vary greatly along the strike. Were it not for the 
fact that this formation is traceable in continuous outcrop, it would be difficult to correlate the beds comprised in it near Garzas Creek with those near Tesla, for the lithologic character of the formation in the two places is different, and in both places fossils are almost entirely lacking. Bluish sandstone like that exposed in the Tesla area forms a part of the San Pablo as far south as Ingram Creek, south of which it forms no noticeable part except near the Crow ranch, south of Crow Creek. Throughout the area between Tesla and Garzias Creek the gradation of the San Pablo into the overlying gravel of the Tulare (?) formation seems perfect. The uppermost sand and gravel beds that are considered as San Pablo are not essentially different from the overlying beds, which are thought to be Tulare. The line between the two formations has been arbitrarily placed at the top of beds which contain abundant fragments of teeth of an extinct species of horse.

South of Little Salado Creek the San Pablo formation dips at a low angle to the east and is well exposed in the low hills between Orestimba and Crow creeks, where it comprises beds of varied lithologic character, some of them being formed of well-worked detrital matter derived from quartzose rocks, some almost wholly of fragmental volcanic material, some largely of fragments of diatomaceous shale evidently derived from the Kreyenhagen shale, and some of fine clay and argillaceous sand whose source is unknown. The basal, 30 to 40 feet, is a coarse-grained, almost pure white friable gritty sandstone formed largely of rounded grains of transparent quartz and light-colored quartzitic rocks. Almost everywhere it is more or less conglomeratic, containing numerous poorly rounded, almost angular fragments, many of which are several inches in diameter. These fragments are very largely red jasper or chert and present a marked contrast to the pure-white sandstone matrix. This bed is overlain by about 30 feet of light-greenish, very friable, almost glassy indurated clay, which is best exposed near the George Crow ranch, where it weathers to very pronounced outcrops. Above the indurated clay are alternating beds of fine white ash, arkose sand, argillaceous sand, and gravel, which vary so much that it is impossible to give any accurate description of their character that will hold for any considerable distance. The following tabulated section shows the general character of these beds:

Section of the San Pablo formation southwest of the 500-foot hill in the center of sec. 7, T. 7 S., R. 8 E., 1 mile east of George Crow's ranch house.

Tulare (?) formation: Feet.

1. Coarse, ill-sorted gravel with fine brownish sand, apparently grading into the beds below.

San Pablo formation:

2. Fairly well cemented, light greenish-brown clayey arkosic sandstone, filled with rounded fragments of diatomaceous shale as much as 1 inch in diameter................... 23 
San Pablo formation-Continued.

3. Light-gray gritty clay, somewhat porous; weathers to light greenish-brown nodular surfaces.

4. Very fine grained light yellow-brown argillaceous sandstone, feebly coherent; formed of rounded grains of quartz and feldspar and fragments of dark rocks....................

5. Light-yellow, somewhat gritty clay, weathering to a rather prominent outcrop................................

6. Very fine grained light-brownish, poorly consolidated clayey

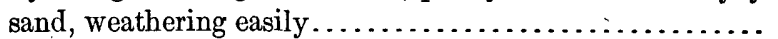

7. Greenish-white clay, filled with peculiar rounded or slightly irregular shaped balls of more compact and slightly darker clay; stained slightly reddish by iron..................

8. Hard, almost pure white ash, containing a few small flakes of dark mica, weathering to prominent outcrops; somewhat porous, like bed 3

9. Very pulverulent fine white ash, filled with flakes of light sulphur-colored mica........................ 13

10. Light-colored clay filled with peculiar clay balls as in bed 7.. $\quad 7$

11. Compact, hard, light greenish-gray sandy clay......... 5

12. Outcrops poor; about 300 yards south, a tuffaceous bluish sand containing small light-yellowish balls similar to those in beds 7 and 10 occurs at this horizon ................ 40

13. White, very friable ash; much like bed $9 \ldots \ldots \ldots \ldots \ldots .16$

14. Compact, very friable light greenish-gray indurated clay, stained along fracture surfaces reddish brown by iron......

15. Massive, medium coarse grained hard friable, white sandstone, formed almost wholly of rounded quartz grains..........

16. Rather coarse quartzose sand like that forming bed 15 , filled with numerous subangular to angular pebbles, which are largely red chert or jasper..........................

Undifferentiated Tertiary:

17. Soft fine-grained friable gray sandstone, containing some slightly bluish sandstone and some fragments of white diatomaceous shale. Fossils are fairly abundant locally, including Nucula, Dosinia, Pecten peckhami, leaves, etc....

Kreyenhagen shale:

18. Soft white diatomaceous shale.

Between Ortigalito and Little Panoche creeks there is a narrow zone, less than 200 feet in thickness, of beds identical with the argillaceous and tuffaceous beds exposed near Orestimba Creek. One of the most prominent beds in this zone is an indurated friable greenish clay stained reddish in irregular blotches and identical in appearance with the indurated bed near the base of the San Pablo formation near Orestimba Creek. These beds rest unconformably upon the Kreyenhagen shale and are overlain, with every evidence of conformity, by beds of gravel and sand that are believed to be equivalent to the Tulare formation. 


\section{RELATION TO PETROLEUM.}

The San Pablo formation is nowhere known to contain petroleum in the area discussed in this report. However, where it rests upon the shale of organic origin belonging to the Moreno formation or the Kreyenhagen shale and where the structure is favorable, oil may have collected in the lower beds. The importance of these beds with relation to petroleum is more thoroughly discussed in another part of this report (pp. 184-194).

\section{TULARE (?) FORMATION (PLIOCENE AND PLEISTOCENE?).}

\section{STRATIGRAPHIC RELATIONS.}

Overlying the Jacalitos and Etchegoin formations along the foothills south of Panoche Pass and the San Pablo formation in the north end of the region are interbedded, feebly coherent brownish sandstone, argillaceous sand, and beds or lenses of coarse ill-sorted gravel. In places these materials are fairly coherent, but usually they are only slightly cemented. These beds are mainly fluviatile deposits, although they include a few calcareous beds that are evidently of lacustrine origin. They are believed to have been formed in much the same manner as the alluvium filling the present San Joaquin Valley. They are here tentatively considered as representing the Tulare formation, although the correlation with that formation at the type locality in the Kettleman Hills is by no means established and is based only on their general similarity in composition and in stratigraphic position. Except for a few very poorly preserved and almost indeterminate shells of fresh-water mollusks no fossils were found in place in these beds north of the Coalinga region.

The Tulare (?) formation is exposed in several separated areas. In most places this separation is only surficial, the formation being almost unquestionably continuous beneath the covering of Recent terrace deposits and valley alluvium. Locally, as in the vicinity of Panoche and Little Panoche creeks, regional deformation and erosion have left isolated masses of the formation resting upon the older rocks.

In most of the region the Tulare (?) rests with every evidence of perfect conformity upon upper Miocene beds (the Jacalitos and Etchegoin formation in the southern part and the San Pablo in the northern), but in the valleys of Panoche and Little Panoche creeks and in the Panoche Hills it overlaps these formations and rests upon the Panoche formation (Upper Cretaceous). As has already been pointed out, the separation between the Etchegoin and Tulare (?) formations south of Panoche Pass is more or less arbitrary, and it is believed probable that these formations were laid down during a single epoch of continuous sedimentation. The same is true of the San Pablo and Tulare (?) formations north of Panoche Pass, where the 
uppermost beds of the San Pablo have been arbitrarily assumed to be those which contain the fossil remains of horses. Where exposed in the foothills bordering the San Joaquin Valley the Tulare (?) continues to the alluvium and embraces the youngest strata which have suffered marked deformation. The attempt has been made to include in the Tulare (?) only, those beds of post-Miocene age which have entered into the folding of the region, and which are now tilted at an angle to the original plane of deposition. In places, as in the hills between Little Panoche and Ortigalito creeks, the Tulare (?) dips steeply along the edge of the valley and is easily distinguished from the flat-lying alluvium. In much of the region, however, the dips increase so gradually westward from the edge of the San Joaquin Valley that only a rough separation can be effected between valley alluvium and terrace deposits and between terrace deposits and the Tulare (?) formation.

\section{DISTRIBUTION, IITHOLOGY, AND THICKNESS.}

In the southern end of the region the Tulare (?) occupies a belt half a mile to a mile wide at the outer edge of the foothills bordering the San Joaquin Valley, from a point a little south of Domengine Creek to a point about 3 miles north of Arroyo Ciervo. It forms broad, irregular areas between Tumey Gulch and Panoche Creek, between Silver Creek and Panoche Valley, along the south side of Panoche Valley east of Griswold Canyon, and along the northwest and southwest flanks and at the crest of the Panoche Hills. Between Little Panoche and Ortigalito creeks and north of Salado Creek it occupies a narrow zone along the edge of the San Joaquin Valley. Near Crow Creek the Tulare (?) rests on the San Pablo in small isolated areas. Beds of unconsolidated sand and gravel that occur along the edge of Livermore Valley are also tentatively grouped with the Tulare (?) formation.

In the foothills south of Tumey Gulch the Tulare (?) partakes of the same general character as the underlying Etchegoin or Jacalitos and Etchegoin formations and is formed mainly of argillaceous brownish sand and feebly coherent sandstone, clay, and gravel. The bulk of the formation is fine grained and is composed largely, in places almost wholly, of light-gray, weathering to brownish or straw-colored, tough clayey sand, formed of fine semiangular grains embedded in a clayey matrix. Locally mica and fragments of serpentine are abundant, fine flakes of serpentine constituting a considerable portion of the whole and forming loose crumbly beds. With the finer-grained sand are numerous irregular beds or lenses of ill-sorted gravel. These coarse lenticular beds are formed of poorly rounded fragments of the older formations and contain among others abundant flat, semiangular fragments of white shale evident!y derived from the Kreyenhagen shale and also poorly rounded fragments of fossiliferous sandstone of 
the Vaqueros formation. From a point south of the Domengine ranch house nearly to Cantua Creek the basal bed is hardened by the addition of a white cement, probably lime, that binds the loose grains together. This bed weathers out to a rather prominent line of irregular hills. It contains numerous large dark-brown sandstone concretions that were evidently derived from either the Panoche, the Moreno, or the Martinez (?) formation. The maximum thickness of the Tulare (?). exposed here is between 600 and 800 feet, but the full thickness is nowhere exposed, as the formation is overlain unconformably by the flat-lying alluvium of the San Joaquin Valley.

Just north of Tumey Gulch gray grit, fine gravel, and clayey sand that are believed to be the equivalent of the Tulare extend up over the early Tertiary beds and form a mantle over the low hills. West of Silver Creek these beds rest with low dips upon the steeply tilted Panoche formation. They have the same general character as the Tulare (?) along the foothills to the south, but to a large extent they lack the abundant fragments of siliceous shale and of fossiliferous bowlders of the Vaqueros formation. The material was probably. derived largely from the Franciscan and Cretaceous rocks. On the whole, the beds are poorly consolidated, but in places beds of coarse dark-gray cross-bedded grit. several feet thick weather out prominently. Silicified wood occurs locally, and about 2 miles northwest of the mouth of Tumey Gulch fragments several feet in length are abundant. In most of the area the dips are low and are irregular both in direction and amount. In the area between Panoche Creek and Tumey Gulch the Tulare (?) has been affected by faulting, which has brought the underlying Kreyenhagen shale to the surface and high dips occur here and there.

The practically flat-lying beds at the crest of Panoche Hills and also the tilted gravel beds on the northwest flank of those hills are tentatively correlated with the Tulare. These beds resemble so closely the recent terrace covering, into which they grade insensibly, that their separation is very difficult and the line as mapped is arbitrary. The strata here mapped as Tulare (?) comprise highly colored beds of gravel, sand, and clay different from anything known in the formation in other parts of the region. The formation is best exposed about 1 mile south of the Mercy schoolhouse, where it weathers to cliffs 100 feet or more in height. These cliffs, with their beautiful coloring of bright blue, red, yellow, and greenish brown, present a marked contrast to the usual somber-tinted outcrops and never fail to attract the attention of a traveler passing through the region for the first time.

The beds comprised in the Tulare (?) vary from fine, very slightly gritty clay to coarse gravel composed almost wholly of fragments 1 inch or more in diameter. In places the beds are calcareous, and 
locally the formation includes irregular beds of impure limestone or marl. Much of the material is but feebly consolidated, although locally it is rather well cemented. Here and there, as at the crest of the Panoche Hills, the consolidation is due to the presence of a calcareous cement, which gives to the beds a light or almost white color. The Franciscan formation evidently contributed a very large part, perhaps all, of the detrital material forming the Tulare (?) in this vicinity. A large proportion of the fragments show the peculiar lithologic character typical of the Franciscan exposed in hills on the west side of Little Panoche Creek, but many of the fragments of sandstone might equally well have been derived from either the Franciscan or the Chico.

The beds capping the Panoche Hills are shown in Plate XII, $A$. They range in thickness from a mere film to more than 100 feet. They are formed, like the Tulare (?) south of the Mercy schoolhouse, of intermingled beds of incoherent clayey sand, gravel, and clay, some of .which show the bright coloring typical of the Tulare (?) in that locality. Besides these somewhat incoherent materials there are thin beds of hard marls or impure limestone and clay and sand more or less impregnated with lime. The development and extent of the calcareous beds are exceedingly irregular. In some places fine sand or clay 25 or 30 feet thick is heavily impregnated with lime, whereas in other places only the uppermost stratum a few inches thick contains appreciable quantities of lime. The layers that might justly be termed impure limestone or marl form but a small proportion of the section.

Between Little Panoche and Ortigalito creeks the Tulare (?) formation is made up of alternating beds of fine sand and gravel, much like those of the same formation farther south. The pebbles in the gravel beds were, however, apparently derived almost wholly from the pre-Tertiary formations and the fossiliferous bowlders of the Vaqueros formation, so common in the Tulare(?) near Joaquin Ridge, are lacking. The maximum thickness of the formation exposed here is about 800 feet.

Between Garzas and Salado creeks the Tulare (?) dips at low angles to the east and is with difficulty separated from the material covering the younger terraces, which it resembles very closely. North of Salado Creek the dip steepens and the formation determines a broken marginal ridge, which in places rises to an altitude of almost 1,000 feet above that of the edge of the San Joaquin Valley, which lies only half a mile to the east. This ridge separates the valley on the east from a broad zone of low land formed by Cretaceous shale on the southwest. It is very prominent just north of Puerto Creek, the elevation known as Hammonds Hill being one of the most conspicuous points of the region. Irregular lenses of gravel, which locally attain 


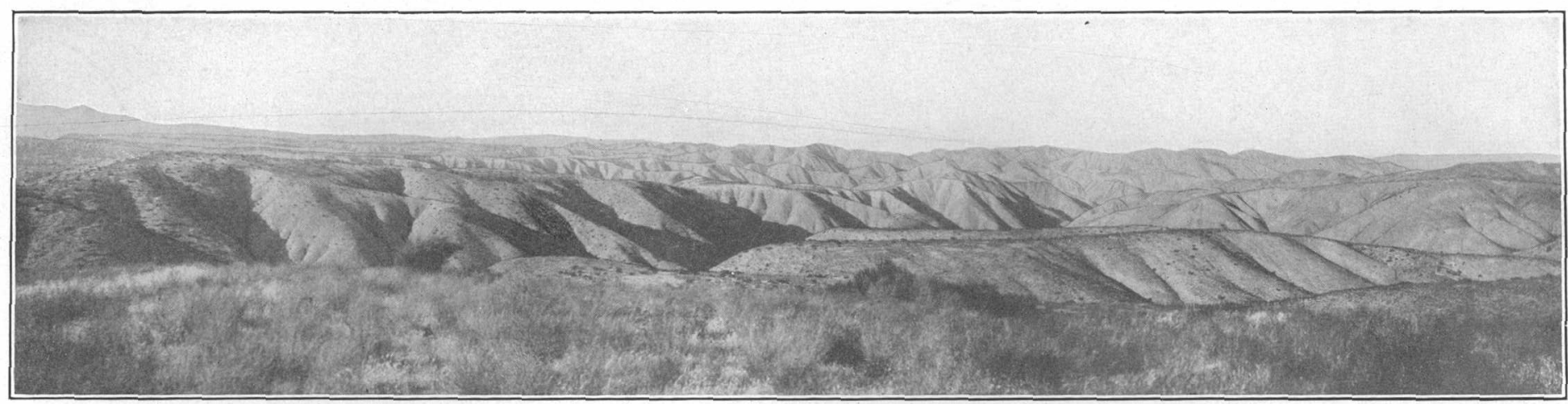

A. TERRACE DEPOSits of THE TULARE (?) FORMATION AT THE CREST OF THE PANOCHE HILLS.

Looking north from a point near the south end of the hills. The flat-topped hills in the foreground and at the left are formed by steeply tilted beds of the Panoche formation capped by flat-lying clay and gravel of the Tulare (?).

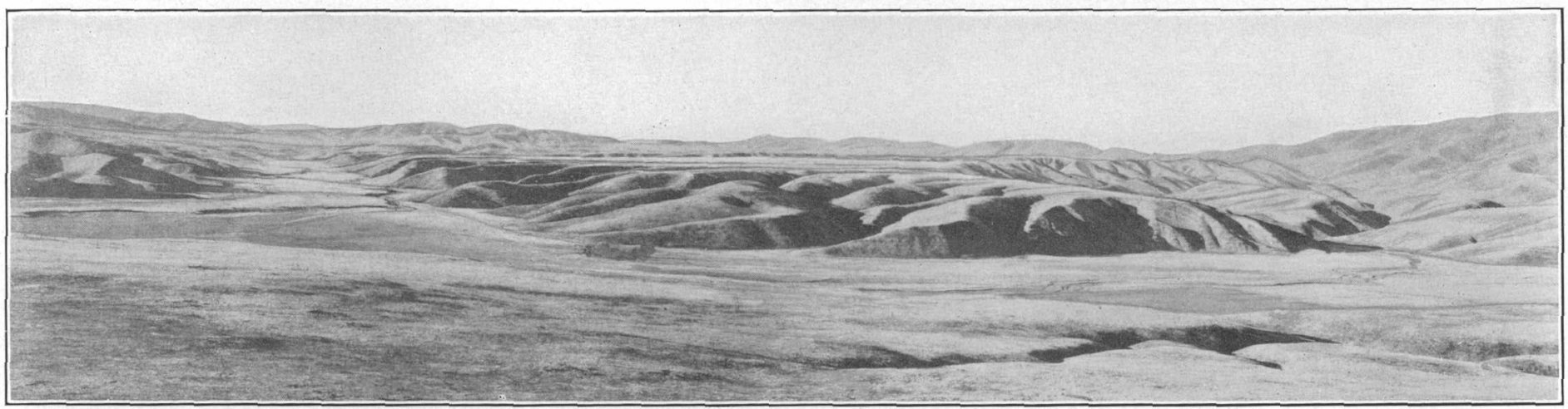

B. TERRACE DEPOSITS IN LITTLE PANOCHE VALLEY.

Looking south up the valley from a point about $1 \frac{1}{4}$ miles south of the Mercy School. The Franciscan rocks form the high ridge on the right; Glaucophane Ridge, separating Little Panoche and Panoche valleys, is shown in the distance at the center; the foothills on the west slope of the Panoche Hills appear at the left. 


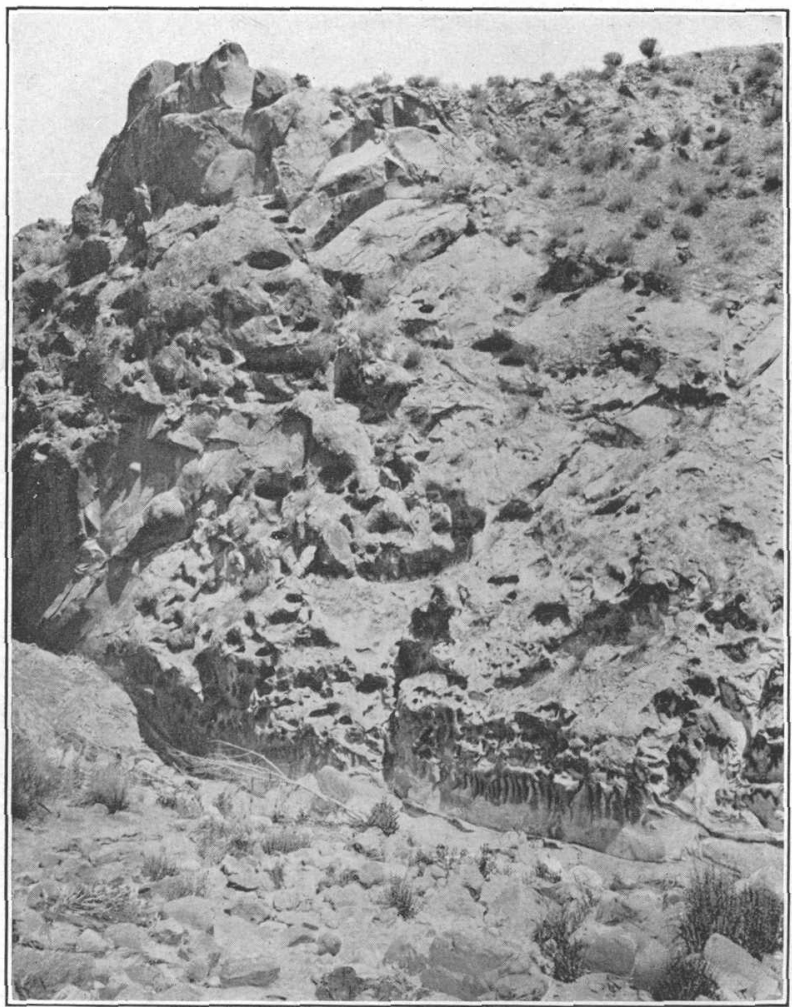

1. CAVERNOUS-WEATHERING CONCRETIONARY SANDSTONE OF THE PANOCHE FORMATION ON EL PUERTO CREEK.

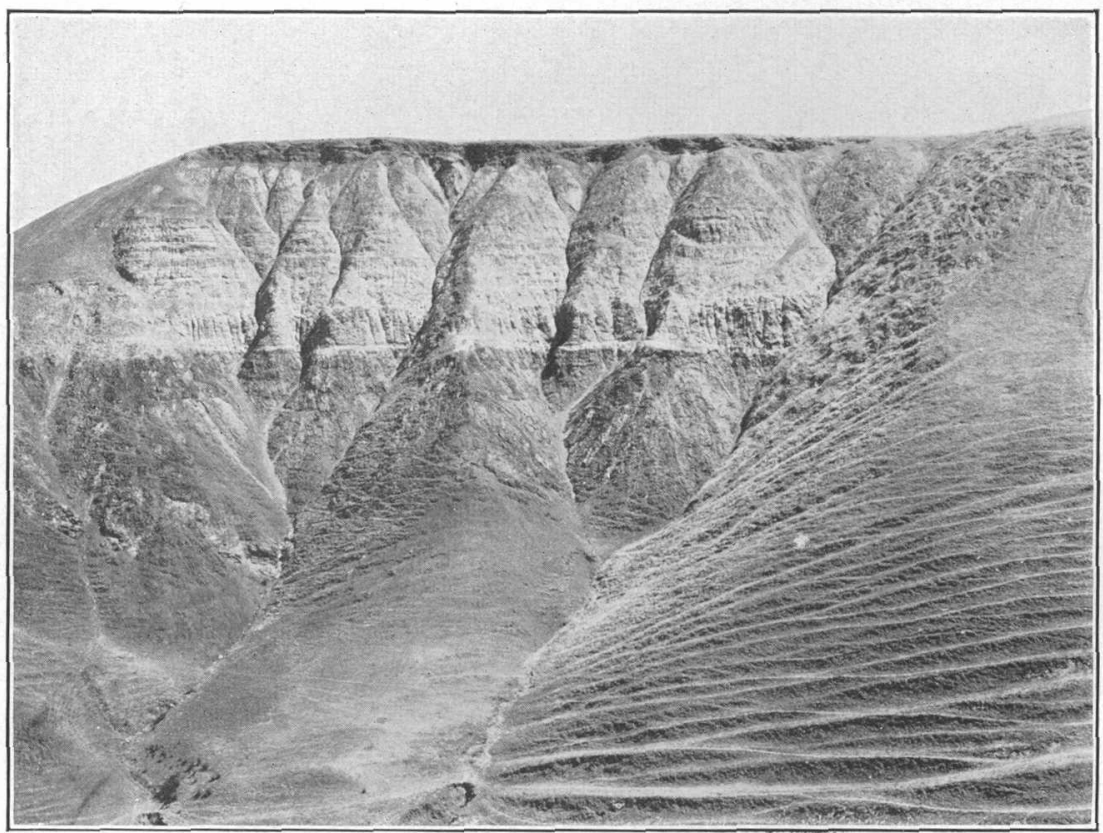

B. TERRACE GRAVELS AND SANDS RESTING ON SHALE OF THE MORENO FORMATION ON ORTIGALITO CREEK.

The Moreno dips directly away from the observer at an angle of $45^{\circ}$. Note the thin dark-colored terrace gravels capping the thick light-colored terrace sands. 
a thickness of several hundred feet, are abundant. The fragments forming the lenses consist. very largely of - pre-Tertiary rocks, large brown sandstone concretions similar to those in the underlying Chico being especially common. The exposed thickness of the Tulare (?) is greatest between Puerto and Corral Hollow creeks, where it has a maximum of not less than 2,300 feet.

RELATION TO PETROLEUM.

No surface evidence was discovered that the Tulare (?) formation contains petroleum in the region treated in this report. In most of the region the Tulare (?) is separated from the shales of organic origin in the Kreyenhagen and Moreno formations by many hundred feet of strata, and it is not probable that any oil which may have had its source in those shales would have migrated through the intervening rocks or strata to find lodgment in the Tulare (?). Between Tumey Gulch and Panoche Creek, however, the Tulare (?) rests directly upon the Kreyenhagen shale, and although no surface evidence of petroleum was seen in the formation, it may possibly contain oil at some depth. In other parts of the region in which this formation occurs its thickness is of importance in relation to the accessibility of possible producing measures in the older rocks over which it forms a cover.

\section{QUATERNARY SYSTEM.}

\section{TERRACE DEPOSITS AND ALLUVIUM.}

The events in this region during late geologic time are chronicled by deposits of material lithologically very similar to the Tulare (?) formation. These deposits form the alluvial filling in the San Joaquin Valley and in the larger structural valleys inclosed within the foothills (Pl. XII, $B$ ); the shallow alluvial fillings in the beds of the larger streams; the covering on the stream terraces that occur from a few feet to several hundred feet above the present beds of the streams; and the broad sheets of gravelly material that rise gradually from the alluvium of the San Joaquin Valley to points over 1,000 feet above its elevation at the edge of the foothills (Pl. XIII, $B$ ). Except for the alluvium of the San Joaquin, Panoche, and Little Panoche valleys, these materials have no great thickness, and locally constitute only a thin veneer over the surface. In many places, however, they very effectually conceal the underlying strata and make it difficult to read the older geologic history.

The similarity between the terrace gravel and sand and the Tulare (?) formation has already been pointed out, and where the dip of the Tulare (?) is low any separation between them is arbitrary. All the formations, particularly the younger Tertiary beds, are also covered by residual soil, which in many places conceals the under- 
lying beds. On the geologic map the larger areas covered by terrace and alluvial deposits have been shown. Besides those mapped, other areas, particularly between Little Panoche Creek and Pancheco Pass, are distinctly benched and covered with an irregular mantle of gravel, which is, however, so thin that it has been disregarded in mapping.

All these deposits are recent, are of superficial character, and have no bearing on the occurrence of oil. In the foothills they are thin and have no appreciable effect on the accessibility of possible oilbearing measures other than that of increasing very slightly the thickness through which it would be necessary to drill in prospecting for oil. In the San Joaquin Valley the recent deposits are believed to have a very considerable thickness and in most of the region that lies but a short distance from the edge of the foothills to form a cover over the Tertiary strata too thick to be drilled through economically at the present time.

\section{IGNEOUS ROCKS.}

Igneous rocks, remnants of both flows and intrusions, are relatively abundant in association with the sedimentary rocks of the Franciscan formation, and their general character has already been discussed.' The Cretaceous, Tertiary, and Quaternary section contains very little igneous material, four small areas of basaltic rocks constituting the only evidence of igneous activity. These are irregular areas of vesicular basalt and tuff in the hills south of Llanada, a small intrusion of basalt in the northwest corner of The Vallecitos, irregular remnants of basaltic flows near Pacheco Pass, and a small dike in the Panoche formation on Wildcat Creek about $1 \frac{1}{2}$ miles above its junction with Los Banos Creek.

The succession of vesicular basaltic flows and tuffs in the hills south of Llanada has a maximum thickness of at least 500 feet. These rocks are extremely diverse in texture, ranging from massive black coarse and fine grained lavas showing glassy phenocrysts of olivine to highly vesicular and pumiceous materials containing fragments of sedimentary quartzose rocks. Their full extent is not shown on the geologic map, for they cover a considerable area north of Bucks Peak, just beyond the edge of the area mapped. About a mile south of Llanada the tuffs with intercalated beds of vesicular lava rest upon the fossiliferous Vaqueros, with which they appear to have suffered an equal amount of folding. Besides this main outcrop there are several small isolated areas of basalt, some of which are indicated on the map. Some of those shown near Bitterwater Creek may be parts of the larger body dropped into their present position by faulting, but others, particularly those south of the synclinal axis, are probably intrusive. The intrusion of these masses is thought to have been 
coincident with the formation of the main part of the tuff and vesicular lava. These beds show a close structural relation to the underlying fossiliferous Vaqueros, and the probability that they are also of lower Miocene age has already been discussed in connection with the description of the Vaqueros in this part of the region.

In the SW. $\frac{1}{4}$ sec. 29 , T. 16 S., R. 11 E., at the foot of the hills bordering the north side of The Vallecitos, a small body of basalt is intruded into the lower Miocene parallel with the bedding and almost at the contact with the overlying ciay of the Jacalitos and Etchegoin formations. It is a dense black rock identical in microscopic character with the coarser-grained basalt near Llanada and is believed to represent an intrusion coincident with the volcanic activity in the Llanada region.

Remnants of small basaltic flows occur in two small areas in the hills south of the road leading away from the east end of Pacheco Pass. The basalt ranges from compact dark-gray or black porphyritic rock to highly pumiceous and fragmental material stained a deep redbrown by iron. In general the lower beds are much more fragmental than the overlying or younger beds, showing that the first outburst of igneous activity was violent. These rocks mark a late epoch in - volcanic activity, and their outburst came after the present topography was largely outlined, as is best shown by the basalt which rests on the top and flanks of Basalt Hill. This hill appears to have been the vent from which the basalt issued. A terrace deposit occurring on the north and west flanks of the hill has been baked by the lava, indicating the recentness of the volcanic activity. The age of the basalt overlying the Franciscan rocks is not so clearly shown as the age of that on Basalt Hill. However, the relation of the flow to the topography supports the hypothesis that it is very recent, and as it is identical in petrographic character with the lava on Basalt Hill, it is very probably of the same age. This flow did not, however, emanate from Basalt Hill but from a vent or vents in the Franciscan rocks, probably south of the east end of Pacheco Pass.

Between 5 and 6 miles southeast of the summit of Basalt Hill, on the prolongation of the line joining the two basaltic bodies already described, the Panoche formation is folded into a small dome whose form strongly suggests that it was caused by some local force acting directly from below. It is believed to have been caused by the intrusion of igneous material which was similar to that forming the flows near the San Luis ranch but which did not reach the surface. This doming is described more in detail under the heading "Structure."

A small basaltic dike about 25 feet thick is traceable for about 800 feet southward from Wildcat Creek in sec. 31, T. 11 S., R. 9 E., where it is intrusive into the lower part of the Panoche formation (Upper Cretaceous). In character it closely resembles the basalt near 
Llanada. Except that it is younger than the earliest Cretaceous beds laid down in this region nothing can be said concerning the age of this intrusion, although its similarity to the post-Eocene basalts suggests its correlation with those rocks.

\section{STRUCTURE.}

\section{GENERAI FEATURES.}

Many of the structural features of the region have already been mentioned in the discussion of the topography and the stratigraphy, and the axes of the principal lines of structure, and the attitude and succession of the strata are shown on the map and in the sections (Pl. I). However, as the attitude no less than the character of the beds plays an important part in the accumulation of petroleum the main structural features will be briefly outlined.

The Diablo Range is in a general sense a broad anticline which has been subjected to long-continued erosion. This erosion has stripped the cover of younger beds from the central part and exposed a core of folded and contorted Franciscan rocks flanked by steeply inclined Cretaceous and younger beds. Although anticlinal the range is by no means a single fold, but in most places it is an assemblage of folds many of which trend obliquely to the course of the range and no one of which can be said to be the dominant feature. Moreover, the range is not due entirely to folding, for in parts of it much of the upward movement took place along faults, and in places, especially in the western flank, faults dominate the structure.

The movements causing the deformation have been active through a long period of the earth's history, but the range in its present form may be said to owe its existence to orogenic movements which occurred in late geologic time and which deformed late Tertiary and early Quaternary beds as well as the older strata. These later movements were profound, and the deformation they produced in the early Tertiary and the Cretaceous strata makes it difficult to recognize the effects of earlier movements upon these beds. In many places the beds from the base of the Cretaceous to the uppermost Tertiary have seemingly suffered an equal amount of deformation, yet the numerous unconformities registered in the section are abundant proof of earlier movements that affected the older beds previous to the time that the younger ones were laid down. Although on the west flank of the Diablo Range much of the movement has taken place along faults, on the east flank such features dominate the structure only in small areas.

A striking feature of the structure of the east flank of the Diablo Range is the gradual increase in complexity southward from a point near the north end of the region discussed in the present report, 
as can be seen by an inspection of the geologic map (PI. I). From a point about 10 miles south of the east end of Livermore Pass southward to Little Panoche Creek there is little to disturb the regularity of the monoclinal structure ${ }^{1}$ of the east flank of the range. The bending of the structure lines between Garzas and Salado creeks and the small anticline north of Salado Creek alone break the regularity. In the Panoche Hills the strata are folded into a low, broad, elongated dome which scarcely reaches the edge of the valley. A few miles to the south is the well-marked symmetrical Ciervo anticline, but this too dies out before reaching the valley. Near the south end of the region mapped is the strong anticlinal fold that determines Joaquin Ridge and continues through the Coalinga district to the south as the Coalinga anticline. All these minor structural features seem to be the expression of the same or similar forces, which have resulted in a flexing of the strata, but the forces have been of greater intensity toward the south and have resulted in that area in the development of larger structural features.

The increasing complexity toward the south is not characteristic alone of the region under discussion but is notable throughout the west side of the San Joaquin Valley. Thus the east flank of the Diablo Range south of the region here mapped contains not only several small folds but also the persistent Coalinga anticline, which parallels the main range and determines the outlying Kettleman Hills. South of the end of the Diablo Range the Temblor Range is the easternmost member of the Coast Ranges. The structure of this range is complex, yet even here the complexity of the folds increases southward. At Midway, near its south end, the main range is formed by a closely folded and faulted mass bordered on the east by two outlying ranges, the Buena Vista and Elk hills, which are determined by anticlinal folds trending somewhat obliquely to the course of the main range. South of Sunset the structure lines swing abruptly to the east and the Temblor Range merges with thie intensely folded and faulted San Emigdio Mountains, which trend east and form a part of the connecting link between the Coast Ranges and the Sierra Nevada.

One very striking feature, which has already been mentioned in the discussion of the topography, is the close relation shown between the structure and the surface configuration. In places not only the major structural features but also many of the minor ones are still reflected in the topography. This preservation is probably in part due to the aridity of the climate and the consequent lack of active erosion over a considerable part of the region,

1 The term "monocline" is used here in conformity with general usage to mean a succession of beds dipping in one direction. Followed to its logical conclusion the term may properly be applied to one flank of an anticline. When the angle to which a succession of beds is tilted increases along a certain line, but the direction of dip remains constant, the beds form a monoclinal fold. 
but more largely to the fact that the structures are extremely youthful and even active erosion would not have been competent to efface them.

The principal minor structural features which appear along the east flank of the Diablo Range are irregular normal faults and anticlinal folds, with their attendant synclines, which trend obliquely to the course of the range and continue from the higher mountains out into the San Joaquin Valley, forming small salient ridges. These folds are much more important structurally than the faults. They are best developed in the southern part of the range and become especially prominent at the extreme end, where the range might be said to finger out into several small structural ridges.

STRUCTURAL DETAILS.

Coalinga anticline and syncline.-The Coalinga anticline, with its supplementary feature the Coalinga syncline, forms one of the principal secondary structures of the region and constitutes the most important of the oblique folds along the east flank of the Diablo Range. Only the north end of the region affected by these features is shown on the map. Both the anticline and syncline continue southward through the Coalinga district for over 50 miles before they are lost beneath the surface of the San Joaquin Valley, the anticline finding its topographic expression in the Kettleman and Lost hills, the syncline in the topographic basins of Pleasant Valley and the Kettleman Plains. In the region that forms the subject of the present report the Coalinga anticline determines Joaquin Ridge, which trends southeastward from the crest of the Diablo Range near New Idria.' In this part of its course the fold plunges southeastward and exposes successively younger formations along its axis.

The Coalinga anticline unquestionably continues northwestward from the contact between the Cretaceous and the Franciscan, which is the farthest point in that direction where the axis of folding is shown on the map, and forms the main axis of folding of the Diablo Range near New Idria. It is, however, difficult or even impossible to follow the axis of the fold in the metamorphic sedimentary rocks and serpentine, and for the present it is mapped only in the unmetamorphosed Cretaceous and younger strata. The north end of the Coalinga anticline is asymmetric, the beds dipping much more steeply on the southwest side than they do on the northeast. Its general form and economic importance have been fully described in the Coalinga report, ${ }^{1}$ to the text of which and to the structural contour map accompanying it the reader is referred for further details. 
Ciervo anticline.-A structural feature only slightly less pronounced than the Coalinga anticline is the Ciervo anticline, which continues from some undetermined point west of the area shown on the map eastward to the foothills near Ciervo Mountain, where it plunges and ceases to affect the strata at the surface. This fold determines the Griswold Hills and Cerro Bonito Ridge, which separate The Vallecitos and the valley of Pimental Creek from Panoche Valley. It is the northernmost of the well-marked folds which continue eastward obliquely from the Diablo Range. Unlike the Coalinga anticline, it is a broad, practically symmetrical fold and does not show the steep dip along the southwest flank that is so characteristic of the Coalinga fold north of Coalinga. West of Griswold Canyon the character of the fold is modified, especially on the north flank, by considerable faulting, and although it has undoubtedly determined the general position of Cerro Bonito Ridge the axis of folding lies considerably north of the summit of that ridge. Cretaceous rocks, probably the equivalent of the upper part of the Panoche formation, are now exposed along the axis of the Ciervo fold in the Griswold Hills. West of Griswold Canyon, in all probability because of faulting, Franciscan rocks appear along or near the axis. The fold was, however, at one time covered by the Vaqueros formation, which now lies as isolated areas on the Panoche formation in the Griswold Hills and probably also in Cerro Bonito Ridge.

Both the Coalinga and Ciervo anticlines have a somewhat curving course. Both trend much more nearly east near the central part of the range than they do in the outer hills, and both swing to a northwest orientation in the low foothills, to conform to the general trend of the range.

Vallecitos syncline.-The Vallecitos syncline is the supplementary structural basin that parallels the Ciervo anticline on the south and separates it from the fold determining the main range, which is here the northwestward continuation of the Coalinga anticline. This basin continues for an undetermined distance westward beyond the edge of the area mapped, determining the valley of Pimental Creek. Like all the other folds in this region, it has a curving course. The topographic basin formed by The Vallecitos and the valley of Pimental Creek closely follows the trough of the syncline and the boundaries of the valley bend and turn in agreement with the twists of the axis. The east end of the Vallecitos syncline plunges northwestward and the fold dies out in the low rolling hills bordering Silver Creek. The syncline is not symmetrical, the dips being steeper on the south side of the axis and the beds there being locally overturned. The area in which the beds are overturned, however, is small and the syncline as a whole is normal. 
Structure in Panoche Hills and Panoche Valley.-The structure lines in the Panoche Hills show a peculiar bending, resulting in an irregular arching or doming of the strata. On the northeast flank of the hills the beds strike regularly about N. $30^{\circ}-40^{\circ} \mathrm{W}$. Toward the south this strike gradually changes, the outcrops of the strata making a curve convex to the San Joaquin Valley, and at the edge of Panoche Valley they trend about N. $40^{\circ}-50^{\circ} \mathrm{E}$. The greatest change in strike is along a line trending about northwest, drawn between the Mercy Hot Springs and Indian Valley. In the northeast flank of the hills the bending is gradual, but near Panoche Valley the structure is less regular and local faults occur. This fold has but little effect on the outer foothills, and the Moreno and younger formations are only slightly affected by it. In the field the change in the direction of the structure lines is readily shown by the outcrops of the harder beds in the lower part of the Panoche formation. The magnitude of the fold may be judged from the map (Pl. I) by the plotted dips and strikes.

The arching or doming of the Panoche Hills may be likened to the Coalinga and Ciervo anticlines, and the fold here regarded as a somewhat irregular and very broad anticline, plunging abruptly southeastward. Panoche Valley must therefore be regarded as the topographic expression of the supplementary syncline separating this fold from the Ciervo anticline on the south. Although this syncline is thus in a way comparable with the Vallecitos syncline, on the south side of the Ciervo anticline, it is not like that feature, a normal syncline, for the strata in place of being simply folded have given way under the forces to which they were subjected and ruptured or faulted along certain lines. Some of these faults are evidently of considerable size, yet the exposures are so poor and so much of the region is masked by alluvium and terrace gravels and sand that many of them can only be inferred from major topographic features and others are doubtless concealed. The faults that are mapped as bounding Panoche Valley on the north and northwest and the one passing through Little Panoche Valley are believed to be three of the principal lines or zones of fracture. These are, however, drawn mainly on topographic evidence, and although they are believed to have very largely determined Panoche and Little Panoche valleys their actual position and magnitude are unknown. The structure in the foothills along the north side of Cerro Bonito Ridge west of Griswold is complex. The beds are broken by numerous faults, and late Cretaceous and Tertiary formation lie in contact with or close to Franciscan rocks. Only a few of the faults in this area are drawn on the map, and a complete understanding of the structure must await a study of the folding and faulting in Cerro Bonito Ridge, which lies just south of this region. 
Structure near Salado Creek.-Northward from the Panoche Hills to the vicinity of Lone Tree Creek, a distance of over 70 miles, the main range is almost unbroken by minor folds in the low foothills. The single exception is the small wrinkle near Salado Creek, which, although formed by the same or similar forces to those forming the larger oblique folds to the south, is in no way comparable in size to those folds. This small anticlinal fold is traceable for about a mile through the low hills near the edge of the plain between Salado and Puerto creeks. Where it occurs both the topographic and the structural lines of the whole east flank of the range bend sharply from a trend of about N. $10^{\circ} \mathrm{W}$. to one of N. $50^{\circ} \mathrm{W}$., a change in direction of $40^{\circ}$. This bending of the structure lines may be considered as comparable to the oblique folds farther south, and the bending to represent an uncompleted fold of that type.

Between Salado and Garzas creeks the Tertiary formations dip atlow angles toward the east, and in places near the edge of the valley lie almost flat. It seems probable that the dip of the beds decreases gradually eastward under the alluvium of the San Joaquin Valley until at some point not far from the edge of the hills they lie horizontal. The possibility should be borne in mind that the line of deformation which finds its expression in the small fold in the foothills between Salado and Puerto creeks may continue southeastward under the alluvium of the valley, and that the dip of the strata south of Salado Creek may not continually decrease eastward, but that along this line the beds may be folded into an anticlinal or perhaps a monoclinal fold. The effect that such structure would have on possible accumulations of oil is discussed in another portion of this report (p. 184).

Structure between Hospital Creek and Livermore Pass.-The structure of the area lying north of Hospital Creek is complicated, and as the mapping in this part of the region is only in the nature of a reconnaissance, many of the features could not be worked out in detail. The principal structural features in this area are the line of acute deformation, marked generally by faults, along the eastern edge of Livermore Valley; the fault along the Franciscan-Panoche contact and its probable continuation into the Panoche south of Hospital Creek, the irregular folds and normal faults in the hills north of Corral Hollow; and the fault along the outer edge of the foothills between Livermore Pass and Hospital Creek.

The faults along the eastern edge of Livermore Valley are almost certainly the southeastward extension of the expression of the forces that formed the overturned and faulted Mount Diablo anticline, which is the dominant structural feature of an area lying some 10 miles northwest of the north end of the region shown on the map. The amount of the deformation in the Livermore Valley area and the form it produced are not known, but it is thought to have resulted 
mainly in normal faults with the downthrow on the west. The movement has certainly been considerable and abruptly truncates the westward trending structure lines in the hills southeast of Greenville.

North of Corral Hollow Creek the beds are flexed into a number of small and very irregular folds and broken by many small normal faults, only a few of which are shown on the map. The principal fold is the Altamont anticline, which trends in a northwesterly direction through the hills near Altamont. This fold was followed for about 2 miles north of the edge of the region shown on the map. The fold is so broad and the dips so low that it is very difficult or even impossible to locate the axis accurately, and its position as shown on the map must be considered as only approximate.

The small irregular anticline whose axis is indicated approximately on the map, trending almost due east through the hills about 2 miles north of Tesla, is a somewhat less pronounced structural feature than the Altamont anticline. It is, however, of considerable importance in relation to the economic possibilities of the region, as the only seeps of oil known in the region occur on its south flank. The character of this fold is described more in detail in another part of the report. (See fig. 5.) The fault along the edge of the valley north of Hospital Creek has not resulted in a great amount of movement and must be regarded as one of the minor structural features of this part of the region.

Los Banos fold.-Where Los Banos Creek cuts through the low ridge about 2 miles east of the Miguel School the Cretaceous strata in a roughly circular area about 2 miles in diameter have been flexed into an irregular fold. South of Los Banos Creek the beds strike about $\mathrm{N} .30^{\circ} \mathrm{W}$. and have an average dip of about $45^{\circ}$, but immediately north of that creek they bend sharply to an east or even slightly northeast strike and have a low dip, in places less than $15^{\circ}$. They hold this attitude for about a mile and then reassume their normal northwest strike with a dip of $40^{\circ}-50^{\circ}$. This fold might be compared to an imperfect dome. The presence of such a fold in the otherwise normally eastward-dipping beds makes it seem natural to assume that it is the expression of local forces. About 6 or 8 miles to the north are two small areas of igneous rock, the remnants of lava which issued from different vents in the vicinity. The possibility that the fold on Los Banos Creek was caused by another intrusion which was similar to those farther north but did not reach the surface is strongly suggested. In this connection it is interesting to note that the line connecting the centers of the two areas of igneous rock near the mouth of Pacheco Pass when projected southward passes through the center of the fold on Los Banos Creek.

Faults.- In general the forces that have produced the deformation of this region have expressed themselves in folds. Locally, where 
the folds have been sharp, where the beds have been too massive to bend readily, where massive sandstone and fine thin-bedded clay shale are interstratified, or where tensional strains of considerable moment have been set up along the axes of the folds, faults have resulted. Faults are, however, not the predominant structural features, and nowhere in the region are they so extensive as they are along the western flank of the Diablo Range. Most of the faults may be considered a secondary result of the folding.

Faults are particularly difficult to trace in this region, for not only do most of the beds weather easily, concealing all trace of crushing along the fault planes, but the lithology of the various beds changes so sharply along the strike that in places it is only with greatest difficulty that any bed can either be followed or its discontinuity adequately proved. In some places the fault is still expressed in the topography, but usually the beds affected are so soft and easily eroded that all traces of fracture are obliterated.

The faults in Panoche Valley and in the area north of Hospital Creek have already been mentioned. Of the other faults shown on the map few are of major importance. Between Hospital Creek and Panoche Pass the Panoche formation rests normally upon the Franciscan except in local areas where the contact is a steep normal fault with the downthrown block toward the east. The lower beds of the Panoche are almost everywhere broken by minute fractures, and in many places it is difficult to determine whether the fracturing is due to local faulting or simply to the close folding the whole region has undergone.

Numerous small faults, a few of which are shown on the map, occur in the beds that form the broken ridge extending northwestward from Joaquin Rocks. These are particularly noticeable at the contacts of the lower concretionary sandstone of the Panoche formation with the underlying and overlying clay shales. They are probably of no great extent and are the natural results of the folding of a succession of interstratified massive sandstone and thin-bedded clay shale.

South of Ciervo Mountain there are a number of small irregular faults with a predominantly northwest trend which were caused by tensional stresses set up in the irregular folding of this part of the region. (See Pl.X.) The fault which passes through the outer foothills from a point near Cantua Creek to Tumey Gulch is the result of the great pressure which has formed the irregular monoclinal fold there. These fractures are superficial.

In general the amount of fracturing which the various beds show increases with their age, owing mainly to the fact that the older beds have suffered a greater amount of deformation, but also in a slight degree to the fact that they are somewhat more massive and more indurated and therefore not only fracture more easily but also better 
preserve evidence of the fracturing. The Franciscan rocks have suffered a tremendous amount of folding and fracturing, but these rocks were not studied in detail and little can be said regarding the faults in them. The numerous normal faults which cut the massive sandstone beds in the lower part of the Panoche formation near Joaquin Ridge are individually small, but collectively represent a considerable movement by which the beds have adjusted themselves to the folding.

\section{PETROLEUM.}

In the following pages will be considered a number of subjects connected with the occurrence of petroleum in this region. These subjects include the evidences of oil actually present in the rocks, the problem of its origin, the comparative features of this region and the oil-bearing regions to the south, the geologic factors bearing especially on the presence or absence of oil, the operations that have been carried on with a view to finding oil, and the possibility of oil being procured in commercial quantity in different areas.

\section{FACTORS INFLUENCING ACCUMULATION OF THE OIL.}

The geologic work on which the present report is based completes an examination of the oil-bearing and possible oil-bearing rocks along the western border of the San Joaquin Valley from the south end nearly to the north end and makes it possible to take a more general view of the features of this province than heretofore. Two questions that are of broadest importance in connection with the occurrence of petroleum in any province present themselves. Why is the oil present at all? Why is it present in certain portions of the province and not in others?. The answer to the first question is believed to be afforded by the fact that the province contains thick formations of shale of organic origin that are thought to have given rise to the oil, and by the presence in association with these formations of moderately folded porous strata that offer excellent reservoirs. The origin of the oil is more fully discussed in another section of this report (p. 194). The second question can not be answered so briefly, because it depends on a great variety of factors, including the presence or absence of an original source of oil in different areas, the favorable or unfavorable character of the rocks as reservoirs, the character of the folds and attitude of the strata, the conditions that existed in past times and the processes of uplift, folding, erosion, and climatic change through which the region has passed, the influence exerted on the oil by ${ }^{\circ}$ underground water and other physical forces, the varying relations of different areas to the larger structural features of the province, and many other conditions. In a general way, however, the province is a unit. The strata and the major features of the structure are similar, and the events experienced 
during the course of geologic history have been, in a broad sense, alike in different parts of the region. For this reason, as thegreater dissimilarities between different portions of the region are comparatively few, it is fairly easy to pick out the features that distinguish those portions where indications of oil are known from those in which oil is lacking. The conclusion appears unavoidable that the dominant factor influencing the accumulation of oil along the eastern flank of the Coast Ranges is the presence of the anticlinal folds in the formations bordering the San Joaquin Valley and the corresponding synclines back of these anticlines. A factor almost equally essential is doubtless to be found in the prevailing underground water system of this great valley. Under the influence of water the oil appears to have been driven into the folds and trapped. In the whole region from the San Emigdio Mountains to Tesla not one of the well-developed folds that border the edge of the valley lacks evidences of the presence of oil either in or near it. On the other hand, there is no evidence of oil at any point not in the general neighborhood of one of these folds. It is not meant to be implied that oil occurs solely along the anticlines, for that is not true, but, as will be brought out below, oil invariably occurs either along such a fold or within an area believed to have been influenced by it. An examination of the province reveals the fact that in addition to seeps or evidence of oil obtained by wells along the anticlines that border the valley, similar indications occur almost invariably in the synclines and minor folds back of these anticlines at points along or in the foothills, whether the beds are or are not folded at such interior points in a way that would ordinarily be considered favorable for the retention of oil. On the other hand, where there is no anticline near the edge of the valley no sign of oil appears either at the edge of the hills or farther back, even though the character and attitude of the beds are practically identical with those of the oilbearing beds at such interior points as are above mentioned. In other words, where an outlying anticline occurs the strata on the farther flank of the inlying syncline are oil bearing, even though they may be steeply tilted and truncated; whereas tilted and truncated beds facing the valley and not inclosed behind an outlying fold are barren. The conclusion is obvious that the anticlinal folds exert some kind of protecting influence on the strata in the foothills to the west.

An excellent example is afforded by the Coalinga field. The strata in the Coalinga anticline, bordering the San Joaquin Valley, show seeps at the surface and yield much oil in wells. The strata forming the west flank of the Coalinga syncline, several miles to the west, are likewise oil bearing, although it can not be denied that if the presence of oil were not indicated by seeps and were not proved by 
the wells the structure in this Westside or Coalinga syncline field, if viewed merely locally and without regard to the broader structure of the region, would not be regarded as very favorable for the occurrence of oil in quantity. At first sight it appears peculiar that oil should have been collected and retained in quantity on this synclinal flank without having escaped up the dip into the upward extension of the beds before they were eroded to their present level.

A similar relation exists in the steeply dipping beds along Reef Ridge, in the southern portion of the Coalinga district, and in the Devils Den district, which form part of the flank of the Diablo Range back of the anticlinal uplift of the Kettleman Hills. The quantity of oil in the beds along Reef Ridge may fall short of being commercially important, but the fact that the aggregate amount distributed through the sandstone is fairly large is demonstrated by the seepages at the outcrop and by the oil that has been obtained in small amounts in certain wells. The mere fact of its presence is important, for it is the question of presence or absence and not the matter of quantity that is under consideration just here. Farther south, along the eastern flank of the Temblor Range, there is a fairly continuous series of oil-bearing outlying folds. Back of these, along the flanks of the corresponding synclines that separate the anticlines from the foothills, the indications of oil at the surface or in wells are numerous, except in a strip southwest of the Lost Hills, where no wells have been drilled and where the beds are largely hidden by alluvium, so that there is no basis for saying whether they are oil bearing or not, although the presumption is in favor of their being so. In this southern area the evidence of the protecting influence of the outlying folds is not quite so clear as it is farther north, owing to the more complicated character of the folds and to the fact that many of them are covered by Recent filling in the San Joaquin Valley. In general, however, the rule holds good that the outer folds are oil bearing and that they are followed on the west by a belt of irregularly tilted strata likewise rich in oil. A good example is afforded by anticlines in the Buena Vista Hills and the highly productive syncline of Midway Valley. It is very doubtful whether the west flank of the syncline would be so productive if it faced directly upon the San Joaquin Valley, without the intervening domes of the Elk and Buena Vista hills.

The relations brought out for the areas above discussed hold good likewise in the Ciervo anticline and Vallecitos syncline, to the north of the Coalinga district, although the amount of oil present there is supposedly small in comparison with that in the developed fields to the south. The Ciervo anticline projects into the foothills, much like the Coalinga anticline, and certain of the beds in the fold show signs of oil. Behind it toward the west is the Vallecitos syncline, 
which, viewed without regard to its broader relations, affords no very favorable structure for the accumulation of oil. Nevertheless the beds on its rather steeply tilted flanks show numerous signs of oil, and small quantities have been obtained in certain wells.

Although the same formations that occur in the Coalinga district and in The Vallecitos, including the large bodies of shale of organic origin, continue northwestward along the border of the valley for over 100 miles, and although their attitude is about like that of the formations in The Vallecitos and in the Coalinga Westside field, they do not give evidence of containing oil. The essential difference between these and the similarly dipping formations back of the anticlines farther south appears to be that the strata on the north have no outlying folds to protect them. There is one place in this part of the region where a type of structure occurs somewhat resembling that of the various oil-bearing areas mentioned in the preceding discussion, but where no oil is known. This is the region of the Panoche Hills and Panoche Valley. The Panoche Hills are formed by an imperfect dome, believed to be partly bounded by faults, and the valley back of them has a structure that may be very roughly compared with that of The Vallecitos or Pleasant Valley. The lack of oil, however, does not affect the theory above proposed, for the reason that the beds supposed to give rise to the oil in the other regions are practically absent in this area. Northward from the Vallecitos and Ciervo areas the first and only definite evidence of oil in the region mapped is in the Tesla district, in the north end of the region. The structure in this district is not strictly comparable with that along the flank of the range to the south, so that different factors enter into the problem, but it is noteworthy that the first true anticline of any considerable size north of the Ciervo region is in the one occurring here.

The accumulation of oil as described above is explainable on the theory that the oblique antielines and the synclines behind them acted as traps to catch and hold the oil that gathered from a wide territory beneath the San Joaquin Valley. The forces causing this migration can not be stated definitely, but the writers believe that meteoric waters have played a large part in the process. The pressure of such water is, however, probably not the only force that caused the migration and accumulation of oil, for it is difficult to believe that it alone could produce the tremendous pressures under which oil is found in certain parts of the field. Water exerts a great if not controlling influence in some of the wells, although as yet evidence on this point is not so full and conclusive as could be desired. It seems reasonable to assume that the greater part of the hydrostatic pressure is produced by the water entering the strata on the Sierra Nevada side of the valley, owing to the much greater rainfall 
on that side and the greater volume of water passing across the foothill belt in streams descending the mountains. The amount of water falling on the Tertiary beds on the west side of the valley is comparatively so small that it may conceivably not suffice to fill even the more porous members of the series to the point of saturation. If this is the case and the greater part of the hydrostatic pressure is exerted from the east side of the San Joaquin Valley, the tendency would be for the oil to be pushed up to an altitude on the west side approximately the same as the altitude of the water table in the particular beds receiving the water on the east side of the valley. Inasmuch as the Tertiary beds either do not rise to a very great altitude on the east side or are not exposed at all at the surface it is very natural that the height of the water table would not be sufficiently great for it to reach the truncated edges of the Tertiary beds which form the hills on the west. The anticlines projecting into the valley on the west side would lift the beds above the altitude of the water table and prevent the passage of the water over the folds into the synclines beyond. Thus the anticlinal crest would become a trap for the oil derived from a considerable extent of territory beneath the valley. The water could, however, pass around the end of the anticline, or across a low portion of it, and enter the syncline, carrying before it the oil from the lower to the higher portion of the plunging syncline. The movement of oil along the syncline would probably be less rapid than in other portions of the region where the beds are more steeply inclined. The Coalinga syncline offers an excellent illustration of the results that may have been produced by this process. A structural depression occurs in the Coalinga anticline at Pulvadero Gap, and it is possible that the Tertiary beds in this depression are sufficiently low to allow the water to pass over the arch. If they are not, the next likely channel for the entrance into the syncline of water from the east would be around the Kettleman Hills, and probably beyond the Lost Hills. In either case the natural place for the oil to accumulate from the whole or a large part of the southeastward-plunging syncline would seem to be at the head of the fold, around Pleasant Valley, where further progress would be stopped by the rising of the beds and the termination of the basin. It is around the upper end of this syncline that the greatest production of the Coalinga field is obtained. The escape of the oil at the surface in this field, owing to the pressure to which the oil is subjected and to evaporation, is no doubt hindered through the sealing of the beds with asphalt.

In the Vallecitos syncline the protection afforded by the Ciervo anticline was probably so effectual as to exclude entirely the waters from the strata beneath the San Joaquin Valley, thus leaving the syncline as a detached basin unaffected by water pressure from the 
surrounding regions and deprived of a large tributary territory from which oil could be gathered. If this train of reasoning is in accordance with the facts, it would be expected that the Vallecitos syncline would lack both the great volume of oil and the high pressure found in the other synclines that form reentrants along the west side of the San Joaquin Valley. It therefore could not compare with them as a possible oil field. On the other hand, if the theory holds good, it throws an interesting light on the possibility that certain areas farther south have a structure analogous with that of the Coalinga syncline. One such area that may be mentioned as worthy of further study in this connection is the supposed anticline of the Antelope Hills and the supposed syncline southwest of it. This area lies at the northeast base of the Temblor Range southwest of the Lost Hills. The structure of this area is obscured by the mantle of alluvium which covers most of it. Surface evidences of oil are lacking in the immediate vicinity, but this may also be accounted for by the alluvial cover and the paucity of exposures and is not necessarily to be taken as an indication of the absence of oil. From what little is known of this area it seems not unlikely that oil will be found here and that the area deserves at least more attention than it has hitherto received.

It remains to consider why the extensive monocline bordering the San Joaquin Valley north of the Coalinga district and extending as far as the northern edge of the region here mapped lacks indications of oil and with the possible exception of a small area near Orestimba Creek is believed to be barren. The lower of the two shale zones that are probably the original sources of the petroleum continues along this monocline, and the upper one is present through much of the distance. There appears to be no reason to doubt that oil might have been formed in this northern region quite as well as in the region of folds to the south. Indeed, in the opinion of the writers it is highly probable that oil did exist in this northern region at one time. But in only a single small area in this region is the structure of the kind that would enable oil to be caught in pockets or that would make local areas points of concentration for oil from a large territory roundabout. Throughout this monocline the beds formerly rose a much greater distance over the older strata and in places arched over anticlinal folds farther back toward the west. This extension has been eroded away, leaving only the roots of the beds, as it were. This is true of the beds between the Coalinga field and Cantua Creek, of the Ciervo anticline, and doubtless to a great extent of the Panoche Hills dome. It is highly probable that the oil supposed once to have been in these beds has been lost through the erosion of their higher portions. 
THE OIL-BEARING FORMATIONS.

The formations which exhibit definite surface evidences of the presence of $\mathrm{o}$ in one or more parts of this region are as follows: The shale of organic origin and the included sandstone lenses in the Moreno formation (Upper Cretaceous); the sandstone and clay of the Martinez (?) formation (lower Eocene); the sandstone of the Tejon formation (upper Eocene); the Kreyenhagen shale (Oligocene?); the sandstone and shale of the Vaqueros formation (lower Miocene); the sandstone of the undifferentiated Miocene (middle or upper Miocene) of the Tesla region; and the sand and clay of the Jacalitos and Etchegoin formations (upper Miocene and Pliocene?) of The Vallecitos. There is also some indication that Cretaceous shale older than that in the Moreno formation may.contain oil in the Tesla region, but the occurrence there is open to different interpretations, as is explained on page 137 .

The formations in which oil is present are practically the equivalents of those in which it occurs in the Coalinga district. The important zones are the two formations containing shale of organic originthe Moreno and Kreyenhagen-and the beds between or immediately above them. No oil has been found in formations other than those mentioned, and such other formations are therefore of only indirect importance in connection with the petroleum problem.

The seeps and other evidences of oil in the different formations mentioned will now be described in detail, beginning with the south end of the region and progressing northward. The seeps and outcrops of oil sand are indicated on the geologic map ( $\mathrm{Pl}$. I, in pocket).

\section{MORENO FORMATtoN (UPPER CRETACEOUS).}

OIL CITY AREA.

The outcrop of the Moreno formation commences near Los Gatos Creek, only a few miles south of the south edge of the area shown on the geologic map (Pl. I). The first definite evidence of petroleum noticed in it is a seep of light oil from the middle of the formation west of the old Oil City camp, in the southwest corner of sec. 17, T. 19 S., R. $15 \mathrm{E}$. Wells drilled into this formation on the Coalinga anticline since the early nineties have found the shale soaked with light oil at shallow depths and have obtained from the lenses and beds of sand lower in the formation commercial quantities of greenish lightgravity oil containing paraffin wax. The seeps of oil in the Oil City area, the impregnation of the shale with petroleum near the surface, and the larger accumulations at greater depth are evidently due to the presence of the Coalinga anticline and the favorable condition it has afforded for the gathering and retaining of the oil. 


\section{MANCILLAS CANYON.}

Northwestward from the Coalinga anticline no more seeps of oil occur along the belt of shale belonging to the Moreno formation for about 30 miles until the region of The Vallecitos is reached. The first seep in this direction is one reported to occur in Mancillas Canyon, south of The Vallecitos, in the western part of sec. 21, T. 17 S., R. 11 E., beyond the area covered by the map. The writers were unable to find it at the time of their visit, but it could easily have been covered by the landslides that have taken place, and the report is credited. The beds in this locality are believed to be the continuation of the shale of the Moreno formation, but severe folding and faulting have affected the strata in this vicinity and no attempt has been made to work out the relations of the formations.

\section{NORTH OF THE VALLECITOS.}

The best seeps known in the Moreno formation are two that occur north of the west end of The Vallecitos, in an east branch of Griswold Canyon, in the NE. $\frac{1}{4}$ sec. 24, T. 16 S., R. 10 E., and the NW. $\frac{1}{4}$ sec. 19, T. 16 S., R. 11 E. One of these is about half a mile up the branch canyon, east of the Griswold Canyon stage road, in the bottom of a north-south gully near which the Union Oil Co. drilled several wells years ago. The oil rises out of steeply dipping beds of slightly maroon foraminiferal clay shale in the upper part of the formation, just about on the line of a northwest fault which causes the shale to strike on the west into concretionary sandstone that normally overlies it. The banks of the gully are soaked with oil for a distance of about 200 feet, and in little prospect holes that have been dug there stands a rather heavy black oil. Some surface layers are slightly asphaltic where the oil has lost its volatile parts. The oil, with little doubt, has its source in the shale of the Moreno formation, and the seep is probably due to oil rising along the fault. Wells drilled in the shale near by obtained small quantities of light oil reported to have had a specific gravity of 0.8433 ( $36^{\circ}$ Baumé) or less.

The other seep occurs about three-fourths of a mile farther up the branch canyon, east of this point, where the canyon bends and cuts across the outcrop of the Moreno formation. This seep is very similar to the first and rises in the creek bottom out of the upper 50 feet of the clayey shale at the top of the Moreno formation as mapped. The beds are fractured and contorted at the surface but in general appear to dip $40^{\circ}-45^{\circ} \mathrm{S}$. beneath massive concretionary sandstone. The oil rises practically at the contact of the clayey shale and the overlying sandstone, but it comes out of the shale and not out of the sandstone. The shale near the contact is in places sandy, giving the appearance of a gradation into the overlying beds through a thickness of about 15 feet. The sandstone is slightly oil stained in 
the basal portion. The crumbly clay along the bottom of the gulch is soaked with oil, which collects wherever a hole is dug. The oil is dark brown and of very fluid consistency and has a strong kerosene odor. Only small amounts of asphaltic residue are noticeable in the soil. A well called the Rebecca was dug here by hand several years ago to a depth of 70 feet and obtained from 2 to 5 barrels of oil a day for several days. Oil stands at the bottom of this well and gradually seeps in again when bailed out. The seep at this place has been known for over 30 years. The following analysis and note on the character of the oil from the dug well was made by Mr. Walter Stalder, of San Francisco, and kindly furnished by Dr. Cottrell, now of the Bureau of Mines. It shows that the oil resembles the asphaltic paraffin oil obtained from this same formation at Oil City, in the Coalinga district.

Synopsis of oil from the Rebecca well, north of The Vallecitos, Cal.

Color, black.

Specific gravity at $60^{\circ} \mathrm{F} ., 0.9119$ (23.5 0 Baumé).

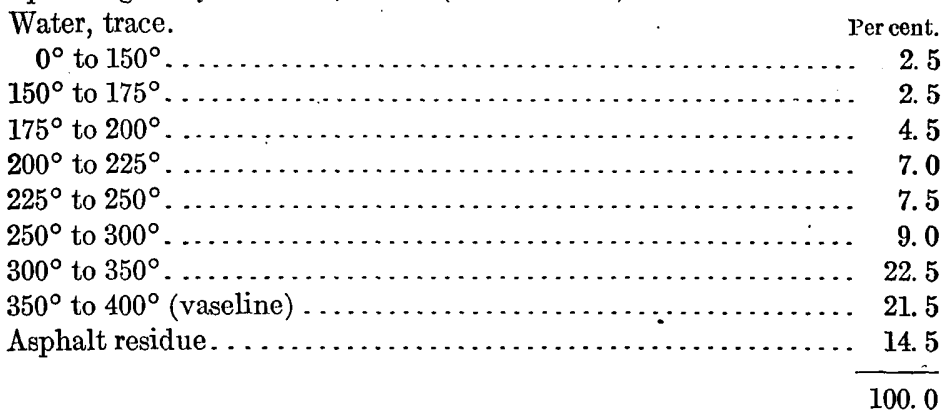

This oil contains scale paraffin and vaseline in its higher fractions. It is not a true paraffin oil but approaches that character, as illustrated by the quantity of vaseline found. The asphalt residue shows the connection with true asphalt oils. This oil is an intermediate grade between a paraffin and an asphalt oil.

Another, much smaller seep was found by the writers in the canyon bottom about halfway between the two already mentioned. Here the oil comes out of the basal 10 feet of the concretionary sandstone.

In addition to these actual seeps evidences of oil are abundant in the shale of the Moreno formation in this vicinity and also west of Griswold Canyon, on the south flank of Cerro Bonito Ridge. Several hundred feet of beds at the top are composed largely of dark clayey shale which in some places has a purplish color, due possibly to oil stain." This shale was found to be oily by digging into it at a horizon about 400 feet below that of the Rebecca well seep. Below the horizon of the clayey shale the typical maroon siliceous shale of the formation, with lenses of sandstone, has a thickness of 800 or 1,000 feet and smells of petroleum almost throughout. In places it is black, as if stained with oil. It is also impregnated with sulphur and gypsum. 
The geologic relations of the seeps just described are interesting. No special structural reasons are known why the shale of the Moreno formation should be unusually oily here. Given the fact that the shale is impregnated with oil, however, the presence of the seeps is not surprising, because the steep dips and fractured condition of the beds favor escape of the oil to the surface. The fact that the oil rises at the Rebecca well out of the clayey beds rather than out of the siliceous shale farther down is worth noting. Supposedly most of the oil had its source in the beds of more purely organic origin below, filtered up through the clay to its contact with the overlying sandstone, and there rose to the surface. This would seem to indicate that the clay is not so great a barrier to the migration of the oil as might be expected, but that, on the other hand, the overlying sandstone, which looks as if it might readily absorb the oil, has acted in that capacity. Indications of oil were noticed only in the basal layers of the sandstone. It should be stated, however, that surface conditions may not be truly representative of those beneath the surface, and it is not impossible that at depths the sandstone contains some of the oil. The fact that the oil is of light gravity and contains a comparatively small amount of asphalt may explain its absence at the surface of the sandstone, from which it might readily become volatilized on exposure to the atmosphere, whereas it would be better retained in the denser clay shale. The passage of the oil through the clay shale and its gathering in this shale zone may be aided by lenses of sandstone which are here and there included in it and which in places are of considerable size.

\section{NORTH OF THE PIMENTAL.}

The shale belt continues from the region of the seeps just described across Griswold Canyon and along the hills north of The Pimental. Its character there is similar and the presence of oil in it is evident.

\section{CIERVO ANTICLINE.}

On the south flank of the Ciervo anticline, 7 miles north of New Idria, lenses of oil sand were found in the shale of the Moreno formation. The sand is dark brown and looks as if it contained bitumen, but it is dry and shows no sign of liquid petroleum. When heated it gives off a distinct petroleum odor, and when treated with chloroform it yields a very appreciable amount of asphaltic oil. A rough estimate indicates that this surface sand may contain oil equal to as much as 2 or 3 per cent or even more of its volume. The lenses of oil-impregnated sand are very local and the exposures are poor, but further search would probably reveal others and possibly more extensive ones. The lenses found are at the north edge of sec. 28 and in the S. $\frac{1}{2}$ sec. 21, T. 16 S., R. 12 E. The adjacent calcareous and siliceous shales of the Moreno formation appear to be oil stained, but the amount of oil, if any, present in them at the surface is small. 


\section{OTHER LOCALITIES.}

Aside from the occurrences so far described no other accumulations of oil or seeps have been found in the shale of the Moreno formation in any portion of its known extent. It is apparent, therefore, that definite evidences of the presence of oil in this formation are not abundant. Various other more or less certain indications, however, occur from place to place. These are of little or no economic importance but are interesting as giving ground for the belief that oil was formerly, at least, widespread in this formation. Throughout the extent of the outcrop parts of the formation have a peculiar chocolatebrown color with purplish tinge, which changes to lavender on weathering. In many places similar shale has a blackish-brown color looking like a stain. The cause of these colors is not certainly known, but similar tints have been noticed in numerous places in the Tertiary oil-bearing shales of California and are suspected of being petroleum stains. It seems probable that the color is due to a combination of petroleum stain and finely divided carbon left by plant remains. At many places an odor of petroleum may be obtained from a freshly broken fragment of the shale or from the included calcareous nodules, even though distant from an area where active seeps are known. Such an odor was obtained, for instance, from a small nodule of limestone included in the shale $2 \frac{1}{2}$ miles southeast of New Idria. In other places lenses of sand associated with these beds bear the appearance of having been at one time oil sands, being brown and lacking clear evidences of bedding, like so many other sands that have been soaked with oil. Such indications are to be noticed, for instance, in interbedded sand and clay overlying the siliceous shale of the Moreno formation in the north branch of Cantua Creek near the point where the Cantua well was drilled, in various sand lenses included in the shale near the Ciervo anticline, as already mentioned, and in similar lenses of concretionary sandstone west of Panoche Creek, just north of the junction of the Panoche Valley road and the Silver Creek road. All these indications can not be positively said to be due to oil, but it is probable that they are. The Cantua well was drilled through this formation without obtaining definite signs of oil. At one horizon only, near the base of the formation, the driller reported "colors of oil." Gas was found at several horizons.

From occurrences such as these it seems probable that much if not all of the Moreno formation in the southern part of the region mapped has at one time been impregnated with oil. North of Little Panoche Valley no absolute evidence of the presence of petroleum in this formation has been discovered; but the lithologic similarity of the shale there to that in the south and the presence of some of the minor indications above mentioned make it seem likely that oil has been pretty widely disseminated through it. Furthermore, 
it is not improbable that the oil occurring in the region west of Tesla comes from this formation. This occurrence will be described in connection with the Miocene.

\section{MARTINEZ (?) FORMATION (LOWER EOCENE).}

Seeps are known in the Martinez (?) formation at three places. The most southerly one of these is a good-sized seep in the bottom of a gulch cutting across the belt of clay which constitutes this formation about 2 miles northeast of Oil City, just west of the center of sec. 9, T. 19 S., R. 15 E. The oil rises out of blackish-gray gritty clay at a horizon below the middle of the formation as mapped, about 200 or 300 feet above the top of the typical chocolate-colored shale of the Moreno formation and 300 or 400 feet below the base of the Tejon. The beds dip about $25^{\circ} \mathrm{E}$. A small quantity of brownish-black oil of fairly light gravity is continually oozing out at two places 50 feet apart. It leaves a small amount of asphalt residue. No special reason is apparent for the escape of the oil at this particular place or at this horizon. The most likely source is the underlying shale of the Moreno formation, but it is rather surprising that the seep does not rise at the top of the siliceous shale instead of from the midst of the overlying mass of clayey beds. The occurrence is almost a duplication of that already described as the Rebecca well seep, north of The Vallecitos, except that here there is no massive sandstone zone immediately over the horizon of the seep. It is not known just where the line between the Cretaceous and Eocene comes in this vicinity, whether at the top of the typical siliceous shale of the Moreno formation, where the line is mapped, or higher, within the seemingly homogeneous body of clay mapped as Martinez (?). It is not impossible that the oil rises along the line of unconformity and thus marks the contact, but no other indication of such a line was found here. Much of the surface is covered with soil and weathered clay and the beds are obscured. Were it not for this cover it is likely that similar seeps might be found at various horizons, or that some special reason would be apparent for the occurrence of the seep at this point. Too much weight should therefore not be placed on the exact horizon of this seep. Lenses of sand occur in places at about this horizon in the clay of the Martinez (?) and may have aided the oil in gathering at this particular point. Such lenses are made up of the greenish glauconitic fossiliferous sand mentioned in the general description of the Martinez (?) formation as occurring near the base of the formation a mile northeast of Oil City and on Salt Creek.

In connection with the position of the above-mentioned seep relative to the structure it is worthy of note that it occurs where the strata undergo within a distance of a thousand feet a gradual change of strike of about $35^{\circ}$. To the south of this point they strike south$81281^{\circ}-$ Bull. 603-15-9 
southwest and to the north they trend north-northwest. This structure is.in a sense that of a very steeply plunging, broad anticline. The foid is really just an irregularity in the zone of uplift whose center is marked by the Coalinga anticline. The presence of oil at the seep may be due to its gathering in this structural irregularity.

The next sign of oil in the Martinez (?) formation to the north occurs on the south side of The Vallecitos near the Hamiltonian well, $1 \frac{1}{2}$ miles south of John Ashurst's ranch. Here a small seep rises from the upper beds of the concretionary sandstone mapped as Martinez (?) 200 or 300 feet south of its contact with the sandstone of the Tejon formation, and another rises about at the contact. The beds are overturned and dip to the south, so that the younger strata underlie the older ones. The source of the petroleum is doubtless the Kreyenhagen shale (Oligocene?), which is oily in the vicinity. With little question the oil reaches the Martinez (?) by migrating up through the porous sandy beds of the Tejon formation, which here is overturned upon the Kreyenhagen shale and lies beneath the Martinez (?).

The third seep known in the Martinez (?) formation is the one already mentioned in connection with the Moreno formation seeps as occurring in the sandstone in the east branch of Griswold Canyon. It is halfway between the Union wells and the Rebecca well, in the NW. $\frac{1}{4}$ sec. 19 , T. 16 S., R. 11 E. At this place a small amount of oil exudes in the creek bottom from the basal 10 feet of the sandstone that immediately overlies the zone of clay shale here mapped as the top of the Moreno formation. There seems little question that the oil has gathered in the sandstone from the underlying oil-bearing shale already described. It should be mentioned that the correlations in this vicinity are not definite and there is no positive proof that the line between the Cretaceous and Eocene is drawn at the right place. The sandstone mapped as Martinez (?) (lower Eocene) and just referred to may possibly be of Cretaceous age. On the other hand, if it is Martinez (?), as it is supposed to be, the oily clay shale immediately underlying it and overlying the siliceous shale of the Moreno (Upper Cretaceous) may properly belong with the Eocene instead of the Cretaceous. The presumption, however, is in favor of the sandstone being the Martinez (?) and the clayey shale being part of the Moreno formation, as mapped.

The presence of valuable accumulations of oil in the Eocene beds along the Coalinga anticline was demonstrated during the later part of 1911 by well No. 80 of the Standard Oil Co., which was started in the Santa Margarita (?) formation, in sec. 28, T. 19 S., R. 15 E., and was drilled down through the Vaqueros (lower Miocene) oil sands and the Kreyenhagen shale (Oligocene?) into the underlying Eocene. A large quantity of paraffin oil of unusually good quality was struck in the Eocene, somewhat below the base of the Kreyenhagen shale. 
To judge by the log of this well, the reservoir of the oil is a sandy layer inclosed in dark-gray clayey and locally sandy shale. A comparison of the log with the sections measured on the surface leads to the conclusion that this reservoir is probably in the clayey beds of the Martinez (?) formation. It can not yet be positively affirmed that this paraffin-oil sand is in the Martinez (?) formation, for the reason that the Martinez (?) and Tejon formations in this vicinity, as well as the bottom part of the Kreyenhagen shale and the top of the Moreno formation, are so similar in character, being fine grained and clayey, that the well log does not give much basis aside from thickness on which to separate them. The horizon is apparently about the same as that of the seep 2 miles northeast of Oil City, above mentioned. The oil doubtless rises into these beds from the petroliferous shale of the Moreno formation below. Its occurrence here is discussed further in the section dealing with the Coalinga anticline field (p. 141).

\section{TEJON FORMATION (UPPER EOCENE).}

In the Kreyenhagen region, south of the Coalinga field, the sandstone of the Tejon formation is impregnated with petroleum through a thickness of many hundred feet, as is made evident both by the outcrops of the sandstone and by wells drilled through it. In the Coalinga field itself no oil has been noted in the Tejon formation ${ }^{1}$ at the surface, but some of the wells southeast of Oil City have found it oil bearing. In the discussion of the different oil zones in the Coalinga anticline field (p. 141) mention is made of the occurrence of oil in the Tejon formation in certain wells, notably wells Nos. 80 and 81 of the Standard Oil Co.

The only other certain indications of petroleum that have been found in the Tejon formation anywhere along the east flank of the Diablo Range are on the south side of The Vallecitos. One of these is in the canyon in which the Hamiltonian well is situated, south of Ashurst's ranch, where oil rises at the contact of the white sandstone of the Tejon and the concretionary sandstone mapped as Martinez (?). As already mentioned, another seep occurs in the Martinez (?) 200 or 300 feet farther up the canyon. In places in the vicinity the sand of the Tejon, which is usually pure white, is found to be stained brown on fresh surfaces, probably owing to the presence of a small amount of bitumen. The oil is believed to seep up through the porous sand beds of the Tejon from the oil-bearing Kreyenhagen shale, which here underlies the Tejon owing to an overturn. The occurrence is local and is not believed to be of economic importance.

\footnotetext{
1 It must be remembered that the Tejon formation as here described does not correspond exactly with the Tejon formation as described in the Coalinga report (U. S. Geol. Survey Bull. 398). The lowermost beds included in that formation in the Coalinga report are here termed the Martinez (?) formation, having been found to contain fossils which correlate them with the Martinez formation at the north end of the Diablo Range; and the overlying shales, which were also provisionally included in the Tejon, are here called the Kreyenhagen shale, for the reasons stated on pp. 74 and 75 .
} 
Another indication was found on San Carlos Creek a little over a mile north of New Idria. The Tejon formation there contains, as elsewhere in this region, interbedded layers and zones of chocolatebrown carbonaceous clay shale. The shale evidently owes much of its brown and blackish color to the presence of finely divided carbon. Some of it contains coal, and much of it shows plant impressions, especially those of marsh grasses. In color, porosity, lightness, texture, and lamination this shale bears a considerable resemblance to the diatomaceous and foraminiferal shale, and it is believed that such organisms were probably once present in it, although a careful examination under the microscope has failed to reveal traces of them still remaining. A sample of the shale from the lower middle part of the formation was treated with solvents by D. T. Day and a minute quantity of a light paraffin oil extracted. Where the oil in this shale comes from is a puzzle, especially in view of its character. It may have migrated stratigraphically downward from the Kreyenhagen shale, which here lies in its normal relation to the Tejon, or, as seems not at all improbable, it may have originated in the shale from contained organic materials, such as the plant remains which were once very abundant in it and the minute organisms whose former presence is suggested by the character of the shale. It is hardly to be supposed that the oil rose from the shale of the Moreno formation, which in this vicinity is separated from the Tejon by several thousand feet of concretionary sandstone. It is very likely that the similar shale beds of the Tejon would be found to contain traces of petroleum in other parts of the region if carefully tested.

It is not improbable that slight indications of oil would be discovered at other points in the sandy beds of the Tejon if they were carefully examined wherever they outcrop. Some indications of the possible previous existence of oil in this formation were noted at various points. For instance, in a canyon 1 mile north of Domengine's upper ranch, in sec. 24 , T. 18 S., R. 14 E., the sandy beds of the Tejon present the appearance of deposits once impregnated with oil. In no place, however, is there any indication of oil in the formation in sufficient quantity to make it likely to accumulate under other than the most favorable structural conditions.

KREYENHAGEN SHALE (OLIGOCENE?).

Although the Kreyenhagen shale is one of the two principal formations in which evidences of oil occur along the Diablo Range, it is not especially characterized by true seeps.. The petroleum appears to have impregnated almost its whole thickness in places, but owing to the fine-grained and homogeneous nature of the formation the oil is in general widely disseminated rather than sufficiently concentrated in liquid form to cause seepage. At several points on the south side of The Vallecitos, however, oil exudes from the steeply 
tilted beds of this formation. The strata consist of typical siliceous shale of organic origin throughout the belt south of the valley, and parts of the formation have become altered to hard, flinty, impervious shale that does not allow the absorption of much oil but affords many small fractures in which oil can gather and along which it can migrate to the surface. This shale is identical in character with the siliceous Miocene shale, belonging to the Monterey group, from which petroleum exudes in so many places along the outer Coast Ranges of California. Three seeps of liquid oil from the Kreyenhagen shale have been noted on the south side of The Vallecitos-in Mancillas Canyon, in the S. $\frac{1}{2}$ sec. 16, T. 17 S., R. 11 E.; in the canyon where the San Carlos well was drilled, in the S. $\frac{1}{2}$ sec. 8, T. 17 S., R. 11 E.; and $1 \frac{1}{2}$ miles farther northwest, in the SE. $\frac{1}{4}$ sec. 6, T. 17 S., R. 11 E. The first two come from the upper middle part of the formation, and the third from beds near its top. Near the locality of the second seep mentioned the San Carlos well was drilled by hand during the early nineties. It started in the steeply dipping oily shale and went to a depth of 166 feet through it, obtaining a sufficient quantity of oil to fill the hole and to refill it gradually when bailed out.

At approximately the same locality as the San Carlos well the Snelling well was started in 1912, and when visited in September of that year it had reached a depth of 800 feet in the Kreyenhagen shale and was obtaining small quantities of a dark-greenish oil. A sample of this oil was kindly examined by D. T. Day, of the United States Geological Survey, who reported on it as follows:

The remarkable thing about it is that for an oil beginning to distill at $160^{\circ} \mathrm{C}$. the specific gravity of the kerosene fraction is very low, indicating that this oil contains a smaller amount than usual of aromatic hydrocarbons. By hard asphalt is meant the asphalt that can be precipitated out by means of light gasoline, according to Holde's method.

Synopsis of oil from Snelling well, The Vallecitos district, Cal.

Specific gravity at $60^{\circ} \mathrm{F} ., 0.8850$ (28.2 ${ }^{\circ}$ Baumé). .

Distillation:

Begins to boil at $160^{\circ} \mathrm{C}$.

Per cent.

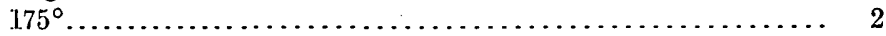

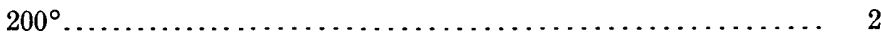

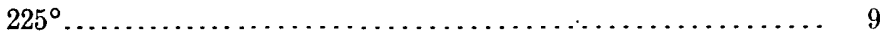

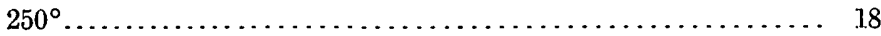

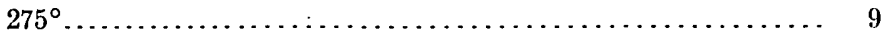

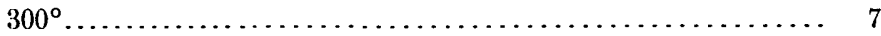

Gasoline and naphtha, none.

Kerosene distillate, 47 per cent by volume.

Specific gravity, 0.8202 ( $40.7^{\circ}$ Baumé).

Residuum, 53 per cent by volume.

Specific gravity, 0.9504 (17.3 Baumé).

Paraffin wax, none.

Hard asphalt, none. 
The composition of the residuum was not determined, but the oil is thought to be an "asphalt oil" comparable in the main with the oil contained in the Miocene formations overlying the Kreyenhagen shale in the Coalinga district, although differing from that oil in certain interesting respects. The sample had been exposed to the air some time before it was obtained, and it is highly probable that a fresh sample would show several per cent of gasoline.

At most other places along the south side of The Vallecitos the Kreyenhagen shale is stained with oil and gives off a petroleum odor. The belt occupied by the petroliferous siliceous shale south of the western part of the valley is at least 3,000 to 3,500 feet across, and as the beds are practically vertical this width would indicate the thickness of the beds unless reduplication by faulting has taken place. No definite evidence on this point has been obtained, nor is it certain that all of this shale is to be included in the Kreyenhagen, the lower portion of it being possibly older.

In addition to the evidences of oil in the Kreyenhagen shale south of The Vallecitos this formation shows signs of being impregnated with petroleum at the east end of the valley and in the vicinity of the Coalinga anticline, at the south end of the region mapped. Where the formation crosses San Carlos Creek, its upper beds, which are unconformably overlain by the Vaqueros formation, smell distinctly of oil. Again 2 miles farther northwest, where it crosses Silver Creek, the beds of shale and indurated sandstone immediately beneath the unconformable Vaqueros are impregnated with oil, are stained blackish, and have a strong sulphurous odor. The same is true on and near the Coalinga anticline, where the formation is oil stained throughout. The shale just underlying the unconformable sand of the Vaqueros formation gives off a strong petroleum odor and shows every sign of having been soaked with oil. Most of the oil, however, has risen out of this shale into the porous beds of the Vaqueros.

Some wells drilled in the Kreyenhagen shale near the Coalinga anticline have found indications of oil at several different horizons and certain wells obtained a small production from it. Among the producers were wells Nos. 2 and 3 of the Phoenix Oil Co., which started near the top of this formation in the SE. $\frac{1}{4}$ sec. 20 , T. 19 S., R. 15 E., and probably did not penetrate as far as its base. Well No. 3 is 560 feet deep and is said to have yielded for a time 50 barrels a day of heavy black oil variously reported to have had a specific gravity between 1.0000 and 0.94 .59 ( $10^{\circ}$ and $18^{\circ}$ Baumé). Well No. 2 was drilled 380 feet deep and obtained similar oil in less quantity. Both were drilled most of the way through white shale interbedded with minor zones of dark shale and oil sand. It is just possible that the deeper well reached the Tejon, but the shallower well certainly drew the oil it obtained from the Kreyenhagen shale and probably both 
did. The heaviness of the oil is an interesting feature of this occurrence. It is believed to have been due to the shallow depth and the disturbed and fractured condition of the brittle shale of this formation on the overturned anticline, which doubtless allowed the escape of the more volatile constituents of the oil. The deep wells, Nos. 80 and 81 of the Standard Oil Co., obtained a slight showing of oil and gas in the middle of this formation.

Although the shale contains from place to place brownish or pinkish discolorations and numerous sandstone dikes that might be ascribed to the former presence of oil, and although it maintains a constant lithologic character in the areas in which it is exposed along the foothills as far north as Salado Creek, in Stanislaus County, no definite signs of oil have been discovered in it in the area discussed in this report away from The Vallecitos and the Coalinga field already mentioned. The sandstone dikes which are so prevalent in the formation from one end of the region to another may have been intruded into fractures in the shale by oil or gas under pressure, and their presence would thus be an indication that oil or gas once existed in these beds. This explanation of their origin seems to be the correct one for dikes in many parts of California, although in other areas, notably in the northern part of the State, water under high pressure is probably the force causing the injection of the sand. The only report of oil having been found in the Kreyenhagen shale north of Panoche Creek is on the George Crow ranch, just north of Orestimba Creek, where the water in a shallow well dug in the lower part of the formation is said to have been covered by a scum of oil when allowed to stand a few days. Whether this was petroleum or not is unknown. It would be surprising if such slight traces of oil were not present in the shale almost everywhere.

\section{VAQUEROS FORMATION (LOWER MIOCENE).}

The Vaqueros formation overlies the Kreyenhagen shale throughout the southern part of the region covered by this report and contains signs of oil wherever such signs appear in the shale below. In the oil field north of Coalinga the main productive formation is the Vaqueros, which is largely of a sandy nature and affords an excellent reservoir for the petroleum that rises out of the unconformably underlying shale. The line of unconformity is marked at the surface in a few places near the crest of the Coalinga anticline by accumulations of asphaltic residue in the basal sand and gravel of the Vaqueros. Such accumulations are surprisingly small and local, however, when it is considered that down the dip of these beds, where they reach depths of 1,000 to 4,000 feet, tens of millions of barrels of oil have been taken from them during the last few years. These outcrops of oil sand are not comparable in size with the asphalt deposits found at 
numerous places along the California coastal belt-in and near the Santa Maria oil field, for instance-or with those in the Temblor Range oil field. The failure of the oil to rise to the surface in greater abundance and escape in liquid form is probably due to its having permeated throughout the sandy beds within a few hundred feet of the surface and deposited residues that have clogged the pores. The best of the outcrops of oil-impregnated sand is in the canyon of the Laval grade, southeast of Oil City. ${ }^{1}$ For most of the way along the outcrops of this Vaqueros oil sand within the Coalinga field no signs of petroleum are noticeable in it, nor do the higher beds of the formation, which are also productive in the wells, show surface indications of their contents.

Northward from the Coalinga field the Vaqueros formation shows no signs of petroleum except around the borders of The Vallecitos. There the beds are oily at each locality where indications of oil occur in the Kreyenhagen shale. The largest outcrop of oil sand is on Silver Creek, at the northeast edge of the valley, in sec. 5, T. 17 S., R. 12 E. At the point where the creek cuts across the contact of the Vaqueros and the Kreyenhagen shale the unconformity between the two is well displayed, the low-dipping sandy beds of the Vaqueros truncating the edges of the slightly more steeply dipping shale. The basal 30 feet of the Vaqueros is impregnated and stained brown with petroleum, especially at the bottom, and although liquid oil does not now appear at the surface; the sand gives the appearance of having been soaked with it at no distant time and of representing an oil-bearing zone beneath the surface. The relation of this oil sand to the oily Kreyenhagen shale is similar to that of the Vaqueros to the Kreyenhagen in the Coalinga field, and leaves little doubt that the presence of the oil in this formation is due to its unconformable position on the shale, and that the oil has risen from the truncated shale beds and collected in the overlying porous sandstone. The basal beds of the Vaqueros formation here consist largely of massive, fairly fine, only locally consolidated gray sand which should afford a good reservoir for oil. Traces of oil were noted in the same sand on San Carlos Creek, where a similar unconformity upon slightly oily Kreyenhagen shale beds is displayed. Indications were also observed on the north side of The Vallecitos 3 miles northwest of Silver Creek, pointing to the probable former oily character of the basal beds of the formation, but these indications were not conclusive. The sandy beds in the middle of the formation exposed along the creek a mile east of John Ashurst's ranch also have an oily appearance.

North of the west end of The Vallecitos, 1 mile north of McDonald's, the sand and sandstone in the middle of the Vaqueros formation 
appear to be oil stained and give off a slight petroleum odor when freshly fractured.

At several places on the south side of The Vallecitos, west of Mancillas Canyon, the Vaqueros shows distinct evidence of being oily. For instance, in the canyon half a mile southeast of the San Carlos well the basal layer of the Vaqueros shows signs that it has contained oil, and the beds within 100 feet above the base have an oil-stained appearance also. In the canyon of the San Carlos well brittle oily shale occurs in the middle of the formation. In this region a zone of white and lavender siliceous diatomaceous shale several hundred feet thick forms the uppermost exposed part of the Vaqueros. The shale resembles that of the Kreyenhagen and is similarly impregnated with oil. In the canyon running back into the hills just southwest of McDonald's ranch a seep occurs at the base of this shale zone. The shale is oily, and liquid petroleum gathers in a small prospect hole dug into it. The strata are steeply inclined and are overturned to the north, but the overturned structure is not believed to extend to a great depth beneath the surface. The source of this oil is a matter of conjecture. It may have originated in this diatomaceous shale, or, as is believed to be more likely, it may have originated in the much thicker body of shale of organic origin in the Kreyenhagen formation and risen to the surface along the contact of the sand and the upper shale zone.

\section{LATER MIOCENE BEDS.}

Seeps are known in only two places in the later Miocene formations of this region. One of these is on the south side of The Vallecitos in the midst of the thick formation of clay that overlies the Vaqueros formation, and the other is on the old Hamilton ranch, in the Tesla district, where the middle or upper Miocene sandstones mapped as undifferentiated Miocene, lie directly upon Cretaceous sandstone and clay shale and show signs of oil at two or more points.

\section{THE VALLECITOS.}

The seep in The Vallecitos is especially interesting owing to its position in the geologio section. It comes to the surface in gravelly beds in the Jacalitos and Etchegoin formations at a point about 2 miles northwest of the San Carlos well. The seep is located in a small gully on the face of the hills, in the southern part of sec. 31 , T. 16 S., R. $11 \mathrm{E}$., about 1,000 feet south of the main road that follows the central portion of the valley. The gully exposes very locally beds of irregular pebbly, coarse sand and tough medium-grained sand interbedded with the clay. Through a thickness of 50 or 75 feet these beds are impregnated with oil and stained deep brown, and the surface sand of the gully is cemented with asphalt for a distance of 150 feet where oil 
has gradually run down the drainage course. At the highest point in the gully where an exposure appears a hole has been dug and a heavy black asphaltic oil gathers in small quantity. The strata dip at an angle of $70^{\circ}$, if not even more steeply, and farther west toward the hills they are overturned. The horizon at which this seep occurs must be at least 1,500 feet stratigraphically above the base of the Jacalitos and Etchegoin formations. It affords a very interesting example of the presence of oil in a coarse lens in the midst of finegrained material into which it would hardly have been expected to make its way.

TESLA REGION.

The next locality north of The Vallecitos in which the post-Vaqueros formations give surface evidence of the presence of petroleum is on the Hamilton ranch, east of Livermore Valley, $2 \frac{1}{2}$ miles northwest of Tesla. Seeps occur here in the southern part of sec. 15, T. 3 S., R. 3 E., Mount Diablo base and meridian. The oil rises out of undifferentiated Miocene sandstone, which rests upon Cretaceous sandstone and shale. The sandstone is of middle or upper Miocene age, the lower Miocene not being represented here.

The seeps are located in two gulches, the eastern one of which drains southwestward through the SE. $\frac{1}{4}$ sec. 15 nearly to the old Hamilton ranch house and thence westward along the south line of the section. The second gulch is tributary to the first from the north, joining it about half a mile below the ranch house. A small outcrop of dry oil sand occurs almost in the bed of the eastern gulch about 200 yards above the ranch house: A few yards upstream from this outcrop a tunnel was started 12 or 15 feet above the bed of the gulch and runs about 40 feet into the east bank. The sand forming the walls of the tunnel is stained by oil in irregular areas and seams and in places is rendered somewhat plastic by the oil still contained in it. Moreover, oil slowly collects to the depth of an inch or two in a shallow hole dug at the face of the tunnel. Natural outcrops of oil sand have been found in the gulch west of the ranch house, and the escape of small quantities of inflammable gas from a marshy area at the junction of the two gulches has been reported. The natural outcrops reported in this gulch were not seen by the writers, but the oily character of the undifferentiated Miocene sand is well shown in a tunnel that was started about midway between the road and the bottom of the gulch, a few hundred feet below the Alisal well. The walls of the tunnel are reeking with oil, which at the time of the writers' visit was oozing from the sand and collecting on water on the floor of the tunnel.

The undifferentiated Miocene here comprises rather poorly consolidated coarse sandstone, gritty or pebbly in places, with lesser 
amounts of interstratified clay or clay shale. These.beds rest with marked unconformity upon the Cretaceous strata. This relation is well shown in the arroyo draining westward through the N. $\frac{1}{2}$ sec. 15, where the low-dipping undifferentiated Miocene may be seen resting upon steeply tilted and somewhat contorted Cretaceous strata. The oil sands noted in the two tunnels occur in the lower part of the undifferentiated Miocene beds not far above the contact with the Cretaceous. The Cretaceous beds exposed in the gulch northeast of the ranch house and in the arroyo draining westward in the N. $\frac{1}{2}$ sec. 15 are in the main thinly laminated dark-brown to black clay shale with numerous beds of fine-grained gray sandstone. These beds are different from the thin-bedded purplish shale of organic origin typical of the Moreno formation to the south and closely resemble the more shaly beds in the Panoche formation. Yet the Moreno formation where last exposed along the road between Livermore Valley and Tesla, about $1 \frac{1}{2}$ miles south of the Hamilton ranch, is formed mainly of dark shale of a very similar character. The Cretaceous beds immediately underlying the undifferentiated Miocene sand at the Hamilton ranch may belong either to the Moreno or to the Panoche formation.

Besides these surface indications of petroleum, oil is known to occur at depth in the Cretaceous beds exposed in this area, and small amounts have been obtained in several of the wells drilled here.

The oil which exudes from the undifferentiated Miocene beds here is believed to have migrated either directly from the underlying Cretaceous beds exposed in this area, or from younger Cretaceous or lower 'Tertiary strata lying farther south, unconformably beneath the undifferentiated Miocene sand and San Pablo formation. These beds therefore hold the same stratigraphic relation to the oil-producing beds as the Vaqueros holds to the Kreyenhagen shale in the Coalinga field. The quantities of petroleum contained in the undifferentiated Miocene beds here and in the Vaqueros formation in the Coalinga field are, however, in no way comparablo.

\section{OCCURRENCE OF OIL IN DIFFERENT AREAS AND FUTURE POSSIBILITIES.}

SCOPE OF DISCUSSION.

The following section will take up the different areas in this region in which indications of petroleum are known or in which there appears to be the faintest possibility that commercial quantities may be obtained and will discuss the various facts bearing on this possibility. Portions of the region which do not appear to offer favorable conditions will be dismissed briefly, with a general statement of the reasons 
for condemning them. The conclusions expressed are to be regarded as the personal opinions of the writers. First, a review of some of the features of the Coalinga field will be presented and then the various portions of the extensive region to the northwest of that field will be taken up one by one, proceeding northward and not in order of economic importance. The areas to be considered are the following:

1. The Eastside or Coalinga anticline field.

2. The Westside or Coalinga syncline field.

3. The outer foothills and valley border from the north edge of the Coalinga field to Tumey Gulch.

4. The inner foothills from the Coalinga field to New Idria and beyond.

5. The region around The Vallecitos.

6. The crest and flanks of the Ciervo anticline.

7. The region around the mouth of Panoche Creek.

8. The foothills and valley border from Panoche Creek to Corral Hollow.

9. The Tesla district.

For those who are interested only in the discussion of those areas in which there appears on the basis of present knowledge to be an economic possibility at all worth considering, a perusal of the sections dealing with areas $1,2,5,6$, possibly 7,8 , and 9 , will suffice.

It has already been shown that the oil-bearing strata and the possible oil measures group themselves in this region about two main formations of organically formed shale-the Moreno (Upper Cretaceous) and the Kreyenhagen (Oligocene?). A discussion of the possibilities of finding oil in various areas therefore divides itself naturally into a treatment of areas in which one or the other or both of these formations and their associated beds outcrop or lie at not too great a depth below the surface. Of the areas above outlined the first and second contain both formations. The third area consists of the belt formed by the Kreyenhagen shale and adjacent beds along the hills northwestward from the Coalinga district. The fourth area comprises the similar belt formed by the Moreno formation, the lower of the two, which in this part of the region is separated from the Kreyenhagen by a great thickness of barren strata. The fifth region contains both formations, which are therefore discussed together. The discussion of the sixth area deals mostly with the lower of the two shale formations, as the Ciervo anticline does not have a very important effect upon the higher shale. Both formations are discussed in connection with the seventh area. The eighth area contains both formations, whose belts of outcrop are not sufficiently distinct nor of enough importance to warrant separate treatment. The ninth area lies in a somewhat different geologic province and does not certainly allow so definite statements concerning the oil-bearing or possibly oil-bearing formations as apply to the whole region from Tesla southward to the south end of the Coalinga district. 
Although the south end of the area shown on the geologic map accompanying the present report (Pl. I) overlaps a little way upon the productive territory of the Coalinga field, no attempt will be made here to discuss in detail the developments in that field, the subject having been treated already in the report on the Coalinga district. It is desirable, however, as a starting point for the discussion of the undeveloped territory to the north, to give a general statement as to the structure and occurrence of oil in the north end of the Coalinga field and to state conclusions as to the probable limits of the productive territory. Such a statement will be of further value here, inasmuch as the geologic work to the north and some of the later developments in the Coalinga field have thrown new light on certain of the geologic relations and economic problems in this field.

\section{STRUCTURE AND OCCURRENCE OF OIL.}

GENERAL FEATURES.

The developed oil field 7 to 10 miles north of Coalinga, embracing the so-called Oil City and Eastside areas, lies on the summit and flanks of the Coalinga anticline, which runs out obliquely from the heart of the Diablo Range to the San Joaquin Valley. This fold not only represents a structural spur of that range but determines a topographic offshoot as well. The axis of the fold plunges rather steeply from the range outward, and along the crest of the fold each of the formations of the region from oldest to youngest passes successively beneath the surface as the valley is approached. Scattered evidences of oil appear at the surface along or near the crest of the fold in four of these formations-the Moreno (Upper Cretaceous), the Martinez (?) (lower Eocene), the Kreyenhagen (Oligocene?), and the Vaqueros (lower Miocene) - and in all of them oil has been found in wells. One other formation, the Tejon (upper Eocene), which lies between the first two and the last two of the four just named, has also been found to contain oil in certain wells. ${ }^{1}$

It is a matter of interest also that petroleum has been reported in a well (the Coalinga Royal) recently drilled through more than 1,000 feet of the shale which underlies the Moreno formation and here makes up the upper portion of the terrane mapped as Panoche. The presence of any appreciable quantity of oil in this lower formation has not been substantiated, however. The five formations first mentioned, from the Moreno to the Vaqueros, occur together in one part of the column and constitute an oil-bearing group about 3,200

\footnotetext{
1 In the Coalinga report these formations were from lack of fossil and stratigraphic evidence described under somewhat different designations-the Moreno as the purple shale at the top of the Chico; the Martinez (?) and Tejon together as the Tejon; and the Kreyenhagen as the shale tentatively included as the upper part of the Tejon.
} 
feet thick. This is increased to 4,000 feet if we add a minor oil sand (locally known as the St. Paul sand) found in certain wells in a local area on the summit of the anticline, 800 feet above the Vaqueros formation, in the upper part of the Santa Margarita (?) or lower part of the Jacalitos. The oil-bearing group would be increased in thickness about 1,500 feet more if it could be demonstrated that more than traces of oil occur below the Moreno formation in the shale penetrated by the Coalinga Royal well, above mentioned. But as yet that has not been demonstrated, and although the possibility of it can not be denied it is not regarded as very probable that any appreciable amount of petroleum occurs below the Moreno. With the single possible exception just noted no oil is known through the many thousand feet of strata either below or above the group mentioned. The stratigraphic range of these oil formations in the Coalinga field is shown graphically in the Coalinga report. ${ }^{1}$ The productive wells obtain their oil from three main parts of the group-the shale and interbedded sandstone of the Moreno formation (Upper Cretaceous), the sandy beds in the Eocene, and the Vaqueros formation (lower Miocene). The occurrence of the petroleum in these three formations will be described separately, and other minor zones will also be noted.

MORENO FORMATION.

The Moreno formation outcrops farthest to the west and farthest up the rise of the plunging fold, being stratigraphically the lowest portion of the oil-bearing group. It is the productive formation of the Oil City area, which was the original area developed in the Coalinga region. The wells start either in the upper part of the Moreno formation, in the overlying Eocene formations, or in the Kreyenhagen shale, and pass down-to productive sands at various horizons from the upper to the lower part of the Moreno formation. These productive sands range through a thickness of at least 700 to 1,000 feet of strata belonging to this formation. They are fine grained and apparently lenticular. The product obtained is a greenish to brownish paraffin-bearing oil, for the most part having a gravity of about $34^{\circ}$ Baumé. It probably originated in this formation, from the great included body of organically formed shale. Although the production from this formation has been relatively small, the quality of the oil has given it importance. It is worthy of note that these productive beds have not yet been tapped by wells started higher in the group than the Kreyenhagen shale, so that their possibilities down the dip, where they lie at greater depths than 2,000 feet below the surface, have not been tested. 
An interesting test has been made by the Coalinga Royal Oil Co. in sec. 8, T. 19 S., R. 15 E., over a mile north of Oil City. The well (No. 2) starts in the lower part of the Moreno formation on the plunging front of the Coalinga anticline and penetrates lower beds than any reached in other wells in this field. The well encountered no petroleum in the shale mapped as part of the Moreno, but the log reports "showings" of oil and gas in sandy beds in the shale that here constitute the bulk of the upper 1,500 feet of the Panoche formation. It is readily believable that a small amount of petro?eum occurs in this older shale, but no indications of it have been discovered at the surface and the presumption is against its being found in appreciable quantity.

The following is a log of the well, kindly furnished in August, 1912, by Mr. Bert Williams, superintendent:

Log of Coalinga Royal Oil Co.'s well No. 2, sec. \&, T. 19 S., R. 15 E.

\begin{tabular}{|c|c|c|c|c|c|}
\hline & $\begin{array}{c}\text { Thick- } \\
\text { ness. }\end{array}$ & Depth. & & $\begin{array}{l}\text { Thick- } \\
\text { ness. }\end{array}$ & Depth. \\
\hline 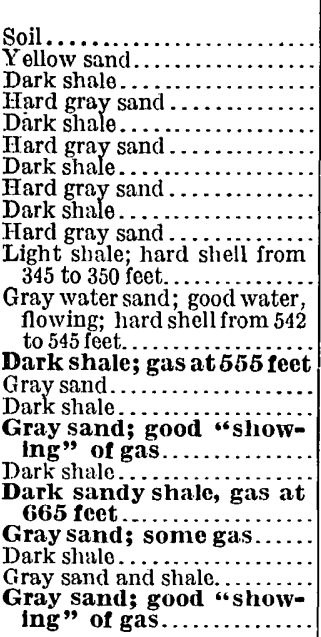 & $\begin{array}{r}\text { Fcct. } \\
6 \\
40 \\
25 \\
2 \\
50 \\
2 \\
15 \\
4 \\
96 \\
5 \\
105\end{array}$ & $\begin{array}{r}\text { Fcet. } \\
0-6 \\
6-46 \\
46-71 \\
71-73 \\
73-123 \\
123-125 \\
125-140 \\
140-144 \\
144-240 \\
240-245 \\
\\
245-350 \\
\\
350-545 \\
545-595 \\
595-623 \\
623-635 \\
635-650 \\
650-660 \\
660-770 \\
770-805 \\
805-816 \\
816-825 \\
825-855\end{array}$ & 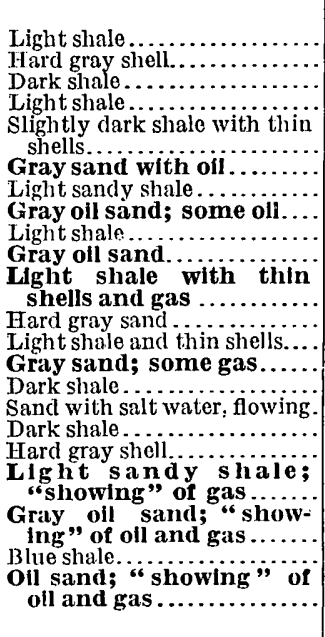 & $\begin{array}{r}\text { Fect. } \\
25 \\
6 \\
49 \\
100 \\
\\
45 \\
5 \\
75 \\
15 \\
375 \\
25 \\
\\
150 \\
3 \\
32 \\
10 \\
5 \\
20 \\
13 \\
2 \\
10 \\
70 \\
5 \\
130\end{array}$ & 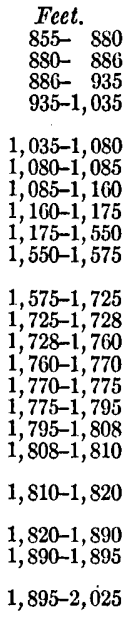 \\
\hline
\end{tabular}

MARTINEZ (?) AND TEJON FORMATIONS.

The clayey shale and sandstone beds of the Eocene overlie the shale of the Moreno formation, and certain sandy strata in the Eocene section are oil bearing. This middle formation has only recently begun to be exploited, having for the first time been drilled into at a considerable depth and found productive in paying quantities in the later part of 1911 in well No. 80 of the Standard Oil Co. Small quantities of very light oil had been found many years previously at about this horizon by some of the wells in the Oil City area, which started in strata not far above this zone and struck it at shallow 
depths. The oil sands of this formation lie either in the Tejon or in the underlying Martinez (?), about 1,000 to 1,400 feet stratigraphically below oil-producing measures of the Vaqueros formation, next to be described. Up to the present writing no well has passed through the productive Eocene strata and tested the beds in the Moreno formation below. The oil-bearing Eocene beds encountered in well No. 80 of the Standard Oil Co. are believed to be approximately marked by the seepage in the west-central part of sec. 9, T. 19 S., R. 15 E., 2 miles northeast of Oil City, where oil rises out of the clay in the lower part of the Martinez (?) formation.

The oil obtained by the Standard Oil Co.'s well No. 80 is different in character from either the oil in the Moreno formation below or that in the Vaqueros above, but of the two it more closely resembles the former. The following is a synopsis of the oil made in the laboratory of the United States Geological Survey under the direction of D. T. Day. The sample of the oil was obtained in 1913, about two years after the well started pumping:

Synopsis of oil from Standard Oil Co.'s well No. 80, sec. 28, T. 19 S., R. 15 E.

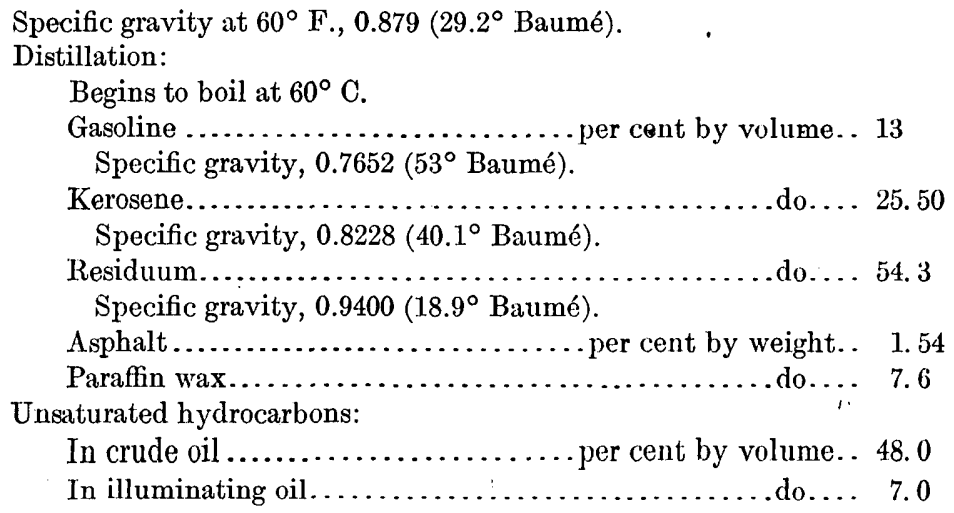

While this oil is lighter in gravity than most California oils, and while the gravity of the illuminating-oil portion is characteristic of paraffin oils and the percentage of paraffin wax is sufficient to characterize it as paraffin oil, it must be borne in mind that the high specific gravity of the gasoline fraction, together with the low point at which the oil begins to boil, shows that the oil contains a marked proportion of aromatic hydrocarbons and probably hydrogen addition products of aromatic hydrocarbons (benzol series). Presence of aromatic hydrocarbons confirmed by testing for benzol with $\mathrm{H}_{2} \mathrm{SO}_{4}$ and $\mathrm{HNO}_{3}$.

The paraffin wax in the oil separates out and clogs the tubing, impeding the flow of the oil and making pumping difficult. The oil is reported to be of better quality for refining than the oil of the Oil City area, but it has been found impracticable to mix this oil with the ordinary product from the Eastside field, as it is said that the mixture is not readily handled. The oil must therefore be stored and transported separately. This well gushed when it first came in and was 
at that time credited with flowing at a rate of several hundred barrels a day. It has since proved capable of yielding about 60 barrels a day under the pump, in spite of the tendency of the oil to clog the tubing.

The following is the log of this well, which was kindly furnished by Mr. E. A. Starke, of the Standard Oil Co.:

Log of Standard Oil Co.'s well No. 80, in the NE. 1 sec. 28, T. 19 S., R. 15 E.

\begin{tabular}{|c|c|c|c|c|c|}
\hline & $\begin{array}{l}\text { Thick- } \\
\text { ness. }\end{array}$ & Depth. & & $\begin{array}{c}\text { Thick- } \\
\text { noss. }\end{array}$ & Dop.th. \\
\hline & Feet. & Feet. & & Fect. & Fee \\
\hline Brown sand & 90 & 0 & Black shale. & 8 & $1,135-1,143$ \\
\hline Blue shale. & 10 & $90-100$ & Dark-brown shale.. & 17 & $1,143-1,160$ \\
\hline Brown sand & 50 & $100-150$ & Oll sand. & 20 & $1,160-1,180$ \\
\hline Brown sandy s & 100 & $150-250$ & Black shale. & 33 & $1,180-1,213$ \\
\hline Blue shale.... & 160 & $250-410$ & Brown shalc........... & 310 & $1,213-1,523$ \\
\hline Gray sand. & 10 & $410-420$ & Blue shale; slight "show- & & \\
\hline Blue sandy sha & 45 & $420-\quad 465$ & Ing" of oll and gas....... & 22 & $1,523-1,545$ \\
\hline Blue shalo... & 5 & $465-470$ & Brown shale............... & 65 & $1,545-1,610$ \\
\hline Oll sand. & 15 & $470-485$ & Blue shale................. & 1 & $1,610-1,011$ \\
\hline Blu & 35 & $485-520$ & Brown shale. . & 169 & $1,611-1,780$ \\
\hline $10 . .$. & 70 & $520-590$ & Blue shale................ & 2 & $1,780-1,782$ \\
\hline $10 \ldots \ldots$. & 10 & $590-600$ & n shalo................ & 188 & $1,782-1,970$ \\
\hline $\mathrm{Fa}$ & 30 & $600-630$ & ............ & 20 & $1,970-1,990$ \\
\hline B & 90 & $630-720$ & hale. & 5 & $1,990-1,995$ \\
\hline Ha & 15 & $720-735$ & Oll sand. & 5 & $1,995-2,000$ \\
\hline Gra & 30 & $735-765$ & Blue shale. & 35 & $2,000-2,035$ \\
\hline Blu & 45 & $765-810$ & Dark-blue shale.............. & 10 & $2,035-2,045$ \\
\hline $\mathrm{Ha}$ & 5 & $810-815$ & Blue shale. . & 10 & $2,045-2,055$ \\
\hline $\mathrm{Bl}$ & 20 & $815-835$ & -bluo shalo.. & 85 & $2,055-2,140$ \\
\hline $\mathrm{Sa}$ & 35 & $835-870$ & shale. & 135 & $2,140-2,275$ \\
\hline Oll : & 5 & $870-875$ & Sandy shell, blue shale, and & & \\
\hline sha & 45 & $875-920$ & $\ldots \ldots \ldots \ldots$ & 20 & 2,275 \\
\hline Oll sand. & 25 & $920-945$ & shale. . & 10 & $2,295-2,305$ \\
\hline Blu & 20 & $945-965$ & Light-blue shale............ & 20 & $2,305-2,325$ \\
\hline andy sha & 30 & $965-995$ & shale.. & 119 & $2,325-2,444$ \\
\hline Wate & 5 & $995-1,000$ & blue shale....... & 2 & $2,444-2,446$ \\
\hline B & 25 & $1,000-1,025$ & BI & 79 & $2,446-2,525$ \\
\hline $\mathrm{Gr}$ & 10 & $1,025-1,035$ & shale ......... & 10 & $2,525-2,535$ \\
\hline shale. & 17 & $1,035-1,052$ & sandy shell. & 2 & $2,535-2,537$ \\
\hline Gra & 4 & $1,052-1,056$ & y shell......... & 8 . & $2,537-2,545$ \\
\hline Sand and gravel & 6 & $1,050-1,062$ & Blue shale. & 6 & $2,545-2,551$ \\
\hline Gray sand... & 8 & $1,062-1,070$ & Hard gray s & 11 & $2,551-2,562$ \\
\hline Blue sandy st & 5 & $1,070-1,075$ & Sticky bluo shale........ & 8 & $2,562-2,570$ \\
\hline Jlard gr & 5 & $1,075-1,080$ & Light-gray s & 5 & $2,570-2,575$ \\
\hline Blue sha & 10 & $1,080-1,090$ & Gray sandy shale....... & 7 & $2,575-2,582$ \\
\hline Gra & 3 & $1,090-1,093$ & ay shell.... & 3 & $2,582-2,585$ \\
\hline Blu & 11 & $1,093-1,104$ & Soft blu & 9 & $2,585-2,594$ \\
\hline Hard whito shale & 6 & $1,104-1,110$ & IIard gray shell. & 1 & $2,594-2,595$ \\
\hline Oll sand. & 1 & $1,110-1,111$ & Oll sand; good "showing". & 43 & $2,595-2,688$ \\
\hline Gray sand & 24 & $1,111-1,135$ & 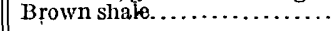 & 7 & $2,638-2,645$ \\
\hline
\end{tabular}

Owing to the lack of reliable lithologic features to distinguish the lower part of the Kreyenhagen, the Tejon, and the Martinez (?) formations and the meager data afforded by well logs, it is difficult to determine the exact position of the oil sands in the Eocene, but that they are within the Eocene formations there is no doubt. According to the writers' interpretation of the log of Standard well No. 80 the oil sands recorded between the depths of 1,970 and 2,000 feet are at the top of the Tejon formation (upper Eocene), and the main oil sand at the bottom of the well, 600 feet lower, is in the lower part of the Martinez (?) formation (lower Eocene). It is possible, however, that this interpretation is at fault and that the 2,000-foot sand, which contains only a trace of oil, is part of the Kreyenhagen and the main sand is in the Tejon. In a later well (No. 81) of the same $81281^{\circ}-$ Bull. $603-15-10$ 
company, drilled in 1912, productive sands were found in fossiliferous beds undoubtedly belonging to the Tejon, and the Martinez (?) has not been reached. This does not prove, however, that the productive sand in well No. 80 is in the Tejon, as it would not be a matter of surprise if higher beds within the general sandy and clayey zone of the Martinez (?) and Tejon formations were found more productive in No. 81 than in No. 80, for the reason that No. 81 is just south of the axis of the anticline, where the strata are more highly disturbed than on the broad face of the fold to the north, where No. 80 is situated. The lenticular nature of the porous sands in the Eocene of this immediate vicinity makes it readily conceivable that a productive sand might be found much higher in the Eocene in one well than in another and such a lithologic variation may explain the supposed difference of position of the sands in the two wells above mentioned, the structural disturbance having had nothing to do with it. In this connection it is worthy of note that the oil found in well No. 81 is heavy, being reported to have a specific gravity of $0.9722\left(14^{\circ}\right.$ Baumé) and to be very different in character from that found in the lower part of well No. 80 .

According to the apparently most reasonable interpretation of the log of well No. 80 it passes through the Santa Margarita (?) formation to a depth of 250 feet; through the Vaqueros formation (including the Big Blue member at the top) to 1,180 feet, where the oil sand mentioned in the log is doubtless the lowest of the productive Miocene sands of this field; through the Kreyenhagen shale, with an included oily bed in the upper middle part, to 1,970 feet; through the Tejon formation to approximately 2,300 feet; and through the Martinez (?) formation to the base of the paraffin-oil sand at 2,638 feet. Below that for a few feet the log reports brown shale, which may possibly be the top of the Moreno formation, inasmuch as it is not unlikely that the zone of oil accumulation is in sandy beds at the base of the Martinez (?). The character and thicknesses of the strata reported in this log tally with the character and measurements of the successive formations as observed at the surface, but it is possible that the formations where measured at the surface are not so thick as they are down the dip where penetrated by this well, and that the well does not reach the Martinez (?) but obtains its oil in the Tejon formation. If that is the case it will be an interesting experiment to test what accumulation of oil there may be, if any, at the base of the Martinez (?) where it comes into contact with the underlying petroliferous shale of the Moreno formation. In any event the possibility that oil may occur in the strata for a thousand feet or more below the oil-bearing Eocene sands is well worthy of testing.

In regard to the source of the oil in the Eocene the most natural conclusion is that it came from the oil-bearing shale of the Moreno 
formation below, which furnishes the petroleum of the Oil City wells. Although the oil is not identical in character with that obtained from the Moreno formation, the above conclusion is borne out by the much greater similarity of the oil in the Eocene formations to the oil in the Moreno than to that in the Vaqueros. The great body of blue and brown shales noted in the log of well No. 80 between 1,180 and 2,595 feet evidently afforded the barrier which kept apart the oil of the Cretaceous-Eocene beds and that of the Miocene beds. At certain horizons within this body of fine-grained material traces of oil were encountered, as for instance at a depth of 1,970 feet, at the base of the brown shale. The sandy beds here are believed to be the uppermost beds of the Tejon formation. It is noteworthy also that not a trace of oil was encountered in the dark clayey beds below this uppermost Eocene horizon until the productive paraffin-oil zone was struck, 600 feet farther down.

VAQUEROS FORMA'TION.

The Eocene oil-bearing beds just discussed are overlain by the diatomaceous shale and gypsiferous clay of the Kreyenhagen (Oligocene?), called in the well logs the "brown shale," which in turn is overlain with great unconformity by the Vaqueros (lower Miocene) formation. The bulk of the oil hitherto obtained along the Coalinga anticline has come from the sandy beds of the Vaqueros. The lower and middle parts of the formation, comprising a thickness of about 600 feet, are composed largely of variable, fine to coarse and even conglomeratic sandstone, some of it highly indurated and some almost incoherent sand. These beds are porous and afford excellent reservoirs for the oil, which is generally found ranging through this part of the formation. The upper part of the formation is composed of the beds known as the Big Blue member, which owing to their fine-grained and compact nature hinder the further upward migration of the oil. Near the central part of the field the Big Blue member consists of fine-grained sand and shale which appear bluish in the oil wells, but farther north and also to the southeast farther down the dip it consists of reddish, bluish, and greenish serpentinous beds. The Big Blue varies in thickness for the most part between 200 and 400 feet, but locally it attains a thickness of over 500 feet. The oil occurs, roughly speaking, in three main zones within the Vaqueros formation below the Big Blue-near the base, in the middle, and near the top-but these zones can not be everywhere differentiated. In general it may be said that the lower 350 feet of strata include the main productive sands of the formation.

The oil-bearing sandstones dip down the flank of the plunging anticline at angles varying for the most part between $9^{\circ}$ and $20^{\circ}$. They display only local and meager evidences of their oily nature at the 
outcrops, considering the amount of oil that is present in them. The wells start in the overlying formations, mostly at points where they will strike the productive sands at depths between 700 and 3,000 feet. The yield of the wells varies, the most productive giving several thousand barrels of oil a day, but the average production during the early years of the life of the wells is between 100 and 200 barrels daily. The oil is dark brown to black in color and of an asphalt base, being very different from the oils in the Martinez (?), Tejon, and Moreno formations. Its specific gravity ranges from 0.9722 to 0.8641 ( $14^{\circ}$ to $32^{\circ}$ Baumé). This oil with little question entered the Vaqueros formation from the oily Kreyenhagen shale below, as is strongly indicated by the concentration of the oil in the lower beds of the Vaqueros just above the plane of unconformity along which the basal conglomerate of the Vaqueros truncates the upturned edges of the shale. The main reasons for this conclusion as to the source of the oil are stated in the portion of this report devoted to a discussion of its origin (p. 194).

KREYENHAGEN SHALE.

In addition to the more productive formation just outlined there are two others in the Eastside field in which oil has been found in wells, and which are worthy of mention both for the scientific interest attached to the occurrence of oil in them and the possibility that locally a production of commercial importance may be obtained from them. These formations are the Kreyenhagen shale and the Santa Margarita (?) formation.

The Kreyenhagen shale is stained with oil at many places and gives good evidence at the surface of being or at least having been impregnated with oil throughout. Most of the beds making up this formation are fine grained and not well suited for the storing of petroleum, so that great accumulations of oil probably do not occur in it. For the same reason it is not surprising that most of the oil supposed to have originated in this shale should have gradually migrated from it into the overlying porous sand of the Vaqueros. Sandy layers or lenses occur here and there in the Kreyenhagen, however, and it is by no means improbable that some of these may contain reservoirs of oil in valuable quantity that has gathered from the surrounding shale. Relatively few wells have penetrated this "brown shale," as it has been the practice to stop the drilling at the top of it. Certain wells drilled many years ago in the Oil City area penetrated this shale, however, and at least two of them-the Phoenix wells, to judge by the logs-obtained oil from it. The Phoenix wells started in the upper part of this formation in the SE. $\frac{1}{4}$ sec. 20, T. 19 S., R. 15 E., on the summit of the Coalinga anticline. One of them (No. 3) went to a depth of 575 feet and the other (No. 2) to 380 feet, 
both passing through light-colored shale most of the way. The deeper of these two wells (No. 3) is reported to have struck three different oil sands, of which the two upper ones certainly are in the Kreyenhagen shale. The third sand, which was struck at 560 to 575 feet from the surface, just below a body of white shale, was almost certainly likewise a sand in the Kreyenhagen, although it may possibly have been the uppermost Tejon. This well is reported to have yielded for some time a production of 50 barrels a day of heavy black oil of specific gravity 0.9859 to 0.9459 ( $12^{\circ}$ to $18^{\circ}$ Baumé). The shallower of the two wells (No. 2) yielded about 25 barrels a day of similar oil from the middle part of the Kreyenhagen shale. The heaviness of the oil obtained from this formation is of interest, inasmuch as it would seem to indicate a closer relation with the oil now contained in the Vaqueros than that before mentioned as obtained from the Moreno and the Martinez (?) and Tejon, and thus tend to bear out the conclusion already expressed that the oil in the Vaqueros was derived from the Kreyenhagen shale. Too much weight should not be placed on the character of the oil, however, owing to the fact that it was obtained at a very shallow depth at the axis of the anticline, near a place where the shale is severely disturbed.

In another well (No. 80 of the Standard Oil Co.), which passed through the Kreyenhagen shale at a much greater depth, a slight "showing" of oil and gas was noted in the upper middle part of the formation, but no sands certainly within this formation were reported in the log. From such evidence as this, as well as from the surface evidence of the scarcity and inconstancy of sandy beds in this formation suitable for oil reservoirs, it is to be expected that the amount of oil obtainable from the formation is very small compared with that in the other oil-bearing zones already mentioned, and that such oil as may occur in it will be found only locally.

POST-VAQUEROS FORMATIONS.

Although all the surface evidences of oil and the sands that have proved productive along the Coalinga anticline occur in the formations already mentioned, an oily formation higher than any of these was passed through by some of the wells in a small part of the field in secs. 27 and 34, T. $15 \mathrm{~S}$., R. $19 \mathrm{E}$. This sand was referred to as the St. Paul sand in the report on the Coalinga district. It was found about 830 feet above the highest oil sand in the Vaqueros (lower Miocene), which would place it in the upper part of the Santa Margarita (?) formation or at the base of the Jacalitos. The presence of oil at this horizon is subject to at least two possible explanations. One is that it migrated upward from the oil sands of the Vaqueros through the Big Blue member and the Santa Margarita (?) formation. The other and seemingly more likely explanation is 
that it migrated along the horizon at which it is found from the area to the west, where the Vaqueros thins and the Santa Margarita (?) and Jacalitos formations become oil bearing, owing to their close approach to the underlying Kreyenhagen shale, from which the oil apparently came originally. These upper Miocene formations constitute the productive zones through a considerable part of the Westside field and are known to contain traces of oil in the wells within 2 miles west of the place where the St. Paul sand is found in the Coalinga anticline.

Although this sand has been found to contain oil only locally along the Coalinga anticline, and then in relatively small quantities, it illustrates the fact that petroleum is not necessarily restricted to the lower part of the Miocene series but may range in some places considerably higher through the sandy beds. It is therefore not altogether impossible that a higher formation than has yet produced any oil in commercial quantities may be found at some points along the Coalinga anticline, although the evidence heretofore obtained does not lead to the belief that this possibility has any great practical importance. The fact that the possibility exists, however, makes it impossible to conclude definitely that the area along the anticline is valueless where the oil sands of the Vaqueros formations are too deep to be reached. As bearing on this point it is important to note that the available evidence suggests that the Vaqueros is probably thicker where it lies at a great depth than it is in the shallow territory. in the western part of the Coalinga field, a condition which weakens the probability of higher zones being productive in the deeper territory.

\section{LIMITS OF THE FIELD.}

To one going northward through the Coalinga oil field and seeing the great productivity of the Miocene oil measures on the flank structures of the Westside area and on the northern flank of the Coalinga anticline, there seems at first sight reason to believe that the strata should continue productive toward the north beyond the developed field, in view of the apparent continuity of the same beds and of a somewhat similar attitude of the strata in that direction. On the other hand, if one starts in the north, say in the vicinity of Cantua Creek, and works southward along the barren strata until he comes to the outcrops of oil sand and seeps in the vicinity of the Coalinga anticline, the impression he gets is quite different. When approached from that direction the productive area seems like a pocket in which oil has locally accumulated under the influence of structural irregularities that do not occur along the regular monocline to the north. A closer study of the geologic features of the region and the data afforded by test wells shows that this view is more nearly correct. There is little doubt that the main cause 
for the localization of this field is the geologic structure, and therefore the conclusion is that the Coalinga field is local and that its outer limits are pretty certainly definable on structural grounds.

The question of particular concern here is, Where does the productive territory of the Coalinga field terminate on the north? This question has already been answered pretty satisfactorily by test wells, but it is important to confirm the result as far as possible with geologic facts and determine the reasons why.it stops. If the conclusion that the Coalinga anticline has been the chief factor in effecting the concentration of the oil is correct the field would be expected to terminate where the influence of this structure ceases. The oil measures would be expected to become at least poorer in oil where the change takes place from the dome structure of the anticline to the uniform flank structure on the north. No single line marking such a change can be drawn definitely, but in a general way the zone of demarcation lies along the northern tier of sections of T. $19 \mathrm{~S}$. A glance at the geologic map shows that the outcrops of the formations change their course in the northern part of this township from north to northwest. In addition the dip of the beds steepens from about $20^{\circ}$ to $30^{\circ}$ or more. Practically all the area of the township north of the line shown on the map as the axis of the Coalinga anticline may be considered as the end of a plunging anticlinal dome, of which the axis drawn merely marks the most acute line of folding that follows the edge of the abrupt southwestern flank. Within this summit area the strata dip at a moderate angle toward the east and form, broadly speaking, an anticlinal arch. In the northern part of the township the beds increase in inclination to $30^{\circ}$ and $40^{\circ}$ and bend their course, as above described, so that from that locality northward they are to be considered as forming the northeastern flank of the fold.

All the surface evidences of oil which led to the original development of this field occur in the summit area thus outlined. North of it for many miles there are no indications of oil along the regular continuation of the strata, whereas if a large quantity of oil were present in these steeply dipping beds there is little question that it would show itself somewhere at the outcrop. These facts explain why the northern part of T. $19 \mathrm{~S}$. is reasonably to be regarded on the basis of the geologic evidence as the northern limit of the area in which any large accumulation of oil might be expected. The anticlinal structure was undoubtedly the determining factor in causing the oil to gather and remain where it is.

The above-stated conclusion is borne out by the results obtained in the wells. All the productive wells north of the axis of the anticline as drawn on the map are confined to the summit area described. Wells drilled in the northern part of the township, near the line 
where the broad end of "the anticlinal fold merges into the northern flank, have proved to be failures. The farthest north that oil has been produced in commercial quantity is in the SW. $\frac{1}{4}$ sec. 2 ; T. $19 \mathrm{~S}$., R. 15 E., where certain of the wells of the Graham and T. C. oil companies obtained a fair yield from sands of the Vaqueros formation. It is noteworthy, however, that taken as a whole the production of wells and the reliance which can be placed on their productivity decrease and the trouble with water increases northward away from the main axial portion of the fold, where the greater number of the wells have hitherto been drilled.

The wells above mentioned which tested the oil measures near the northern edge of T. $19 \mathrm{~S}$. and proved failures were those of the Imperial Oil Co., drilled in 1908 and 1909 in the NE. $\frac{1}{4}$ sec. 2. These were within half a mile northeast of the most northerly productive wells and were both farther north along the strike and farther down the dip of the beds. They served to demonstrate pretty clearly that the oil sand in the Vaqueros formation becomes barren of oil somewhere between these two sets of wells-that is, about half a mile south of the northern edge of the township. It is noteworthy that this position almost exactly coincides with the line of most pronounced change in strike of the beds from a north to a northwest direction.

The wells of the Imperial Oil Co. penetrated the same zones encountered in the wells in the main field to the south, as was to be expected from the perfect continuity of the formations. At least one of the wells went some distance below the Vaqueros (lower Miocene) into the "brown shale" of the Kreyenhagen. It passed through the big oyster beds or Tamiosoma zone of the Santa Margarita (?) formation between 1,400 and 1,600 feet below the surface; through reddish and sticky bluish serpentinous beds recognizable as part of the Big Blue member from about 1,900 to 2,200 feet; and thence down to 3,166 feet through the sands and shales in the lower part of the Vaqueros, which farther south contain oil but in which no petroleum was found here. Water was encountered in this lower part of the Vaqueros, supposedly at a horizon 200 or 300 feet above the base of the formation, but it was not under sufficient head to produce a flow. Its temperature was said to be over $150^{\circ} \mathrm{F}$. According to the driller no water was encountered in the basal portion of the Miocene, which is the main oil sand elsewhere, nor in the Kreyenhagen shale below it. This shale was penetrated for several hundred feet before the well was abandoned. The only signs of oil obtained were occasional iridescent films on the bailings from the lower Miocene and a faint oily smell. The following is the driller's log of this well, which is fairly representative of the logs in this vicinity: 
Log of Imperial Oil Co.'s well No. 1, in the SW. $\frac{1}{4}$ NE. $\frac{1}{4}$ sec. 2, T. 19 S., R. 15 E.

\begin{tabular}{|c|c|c|c|c|c|}
\hline . & $\begin{array}{l}\text { Thick- } \\
\text { ness. }\end{array}$ & Depth. & & $\begin{array}{l}\text { Thick- } \\
\text { ness. }\end{array}$ & Depth. \\
\hline & Feet. & Fcet. & & Feet. & Fect. \\
\hline Surface eart & 20 & $0-\quad 20$ & Sandy shale & 35 & $1,900-1,935$ \\
\hline Yellow earth & 20 & $20-\quad 40$ & Blue mid....... & 29 & $1,935-1,964$ \\
\hline Sticky blue clay... & 20 & $40-60$ & Red rock.............. & 186 & $1,964-2,150$ \\
\hline Blue sandy shale wlth & & & Pink clay .. & 29 & $2,150-2,179$ \\
\hline water $\ldots \ldots \ldots \ldots \ldots \ldots \ldots$ & 20 & $60-$ & Sandy blue clay ......... & 71 & $2,179-2,250$ \\
\hline Brown shale & 40 & $80-120$ & Gray sand, showing gas...... & 60 & $2,250-2,310$ \\
\hline Sand shell.. & & $120-125$ & Gray sand, loose; some & & \\
\hline Sticky brow & 165 & $125-290$ & sulphur water $\ldots \ldots \ldots \ldots$ & 15 & $2,310-2,325$ \\
\hline Dark-gray s & 40 & $290-330$ & Gray sand, becoming lighter.. & 100 & $2,325-2,425$ \\
\hline Sticky blue & 460 & $330-\quad 790$ & Blue shale, sandy...$\ldots \ldots$ & 60 & $-2,485$ \\
\hline gray & 10 & $790-800$ & Light-brown sandy shale, & & \\
\hline Blu & 130 & $800-930$ & 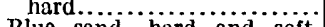 & 58 & $2,485-2,543$ \\
\hline Gray & 10 & $930-940$ & Blue sand, hard and soft & & \\
\hline Blue & 35 & & streaks $\ldots \ldots \ldots \ldots \ldots \ldots \ldots$ & 37 & $2,543-2,580$ \\
\hline $\begin{array}{l}\mathrm{D} \\
\mathrm{Bl}\end{array}$ & $\begin{array}{l}50 \\
25\end{array}$ & $\begin{array}{r}975-1,025 \\
, 025-1,050\end{array}$ & Glay and sand $\ldots \ldots \ldots \ldots$ & 10 & $\begin{array}{l}2,580-2,590 \\
2,590-2,592\end{array}$ \\
\hline Hard & $\begin{array}{r}20 \\
5\end{array}$ & $\begin{array}{l}-1,050 \\
-1,055\end{array}$ & Gray sand with gravel & 2 & $2,090-2,59$ \\
\hline $\mathbf{B}$ & 30 & $1,055-1,085$ & clay $\ldots \ldots \ldots \ldots \ldots \ldots \ldots$ & 50 & $2,592-2,642$ \\
\hline Gray sand. & 60 & $1,085-1,145$ & Sticky clay.. & 14 & $2,642-2,656$ \\
\hline Sandy shale. & 25 & $1,145-1,170$ & Sandy sholl, hard. & 27 & $2,656-2,683$ \\
\hline . & 42 & $1,170-1,212$ & Sand and clay .... & 17 & $2,683-2,70$ \\
\hline sha & 58 & $1,212-1,270$ & gravel and & & $2,700-2,70$ \\
\hline Blue clay, sandy shale, and & & & Sand and clay ....... & 40 & $2,704-2,744$ \\
\hline sand..... & 185 & $1,270-1,455$ & Hard shell... & 2 & $2,744-2,74$ \\
\hline Oyster shell & 10 & $1,455-1,465$ & Dark-blue elay & 7 & $2,746-2,753$ \\
\hline Bl & 35 & $1,465-1,500$ & and clay. & 187 & $2,753-2,940$ \\
\hline Hard blue cl & 90 & $1,500-1,590$ & z-blue sandy shal & 72 & $2,940-3,012$ \\
\hline Gray limerock. & 20 & $1,590-1,610$ & Gray running sand & 3 & $3,012-3,015$ \\
\hline Sar & 20 & $1,610-1,630$ & ay shell. . & 5 & $3,015-3,020$ \\
\hline mud and wate & 30 & $1,630-1,660$ & Dark-bluo sandy clay.... & 88 & $3,020-3,10$ \\
\hline Muddy se & 25 & $1,660-1,685$ & Hard lin & 37 & $3,108-3,14$ \\
\hline Gra & 10 & $1,685-1,695$ & Stiff greenish clay & 21 & $3,145-3,16$ \\
\hline Bro & 45 & $1,695-1,740$ & Brown shale... & 209 & $3,166-3,375$ \\
\hline Dark s & 140 & $1,740-1,880$ & Brown shale becoming lighter. & 131 & $3,375-3,506$ \\
\hline Dark-b & 20 & $1,880-1,900$ & & & \\
\hline
\end{tabular}

Little more is to be said regarding the limits of the Eastside field, for the reason that they are pretty well outlined already. There is no question that most of the field, including its best part, has been tested. The principal features of the field that offer untested possibilities are the oil-bearing formations below the Miocene, in which the extent of the petroleum both areally and vertically has not been thoroughly demonstrated. The field offers a distinct possibility of yielding high-grade petroleum from the sandy beds in the Martinez (?) or Tejon formations below the Kreyenhagen shale, and from the Moreno formation (Upper Cretaceous) still farther down, when wells are drilled along the Coalinga anticline so as to strike these formations at places where they are under sufficient cover. As regards the areal extent of beds older than the Miocene from which oil can be economically obtained, it is safe to say that their outer or lower limit falls well within the productive beds in the Vaqueros formation, owing to the much greater depth to which it is necessary to go to reach the lower formations. The knowledge of the occurrence of oil in the lower formations so far gained indicates that the character of the material in these formations is not quite so favorable for the accumulation of oil as that in the Vaqueros, and that probably the total volume of oil collected in them is not so great as in the Vaqueros. These con- 
siderations give reason for believing that the area within which it will pay to exploit the lower strata will be smaller than the productive Vaqueros area. The same conclusion is indicated by the fact that the anticlinal fold is probably somewhat sharper-that is, its summit is somewhat narrower-in the older formations than in the Vaqueros, a fact which would tend to place a narrower limit upon the area favorable for accumulation.

It is believed that the production to be expected from wells drilled into the Vaqueros at a distance from the main axial portion of the fold will decrease down the dip, beyond the zone most favorable for accumulation, which seems to lie roughly between 1,000 and 2,000 feet below the surface. From the outcrop down to some such depth the conditions appear to improve. It is reasonable to suppose that similar considerations apply to the oil measures in the pre-Miocene beds - still another indication that portions of the Martinez (?), Tejon (Eocene), and Moreno (Upper Cretaceous) formations will be found productive over an area less extensive than the area of productive Vaqueros formation (lower Miocene). The productive area of the older beds does, however, extend beyond the inner or upper limit of the Vaqueros, as shown by the developments at Oil City. There is a considerable strip of territory over a mile in width, between the outcrops of the Moreno formation on the northwest and the area in which wells are producing from the Vaqueros formation on the southeast, in which the possibility is excellent of oil being obtained at reasonable depths from the Martinez (?) or Tejon and the underlying shale of the Moreno by drilling down through part of the Miocene, the Kreyenhagen, and the Martinez (?) and Tejon formations. This area has hitherto been largely overlooked by operators owing to the shallowness and relative barrenness or entire absence of the sands of the Vaqueros formation. The portion of this strip on the axial part of the anticline and within a mile or so northward from the axis offers the most favorable places for testing the possibility of the Tejon, Martinez (?), and Moreno formations. As a matter of fact the favorable area extends farther southeast and overlaps the area of highly productive wells in the Vaqueros. The area in which oil may possibly be obtained from these older beds can not be said to be confined within these limits but may extend northward almost as far as the sands of the Vaqueros formation are productive, as well as eastward down the dip and perhaps westward for a little way within a very restricted area. The most favorable area, however, lies, roughly, within $1 \frac{1}{2}$ or 2 miles southeast and east-southeast of the old Oil City field, and the expenditure of money in testing the outlying territory may well await the results obtained here and the gradual feeling of the way by wells as they extend the proved ground. 


\section{WESTSIDE OR COALINGA SYNCLINE FIELD.}

REASON FOR DISCUSSION.

Although it is not in the province of this report to discuss fully the Coalinga oil field it will not be out of place to mention certain problems of the Westside area, or, as it may be called, the Coalinga syncline field, upon which light, has been thrown by some of the recent developments and by the studies of the region to the north. This area lies to the southwest of the territory along the Coalinga anticline already discussed and comprises the larger portion of the main Coalinga field. It may be defined as the productive area along the northwest and west sides of Pleasant Valley, on the west flank and around the head of the Coalinga syncline. The following discussion will be clearer if reference is made to the maps of the field published in the report on the Coalinga district. ${ }^{1}$

\section{STRUCTURE AND OCCURRENCE OF OIL.}

The general structure of the Westside field is that of the fairly regular flank of a syncline dipping at a moderate angle toward the - east and truncated at the surface on the west. The Coalinga syncline, on the western flank of which this field lies, is an elongated asymmetric trough or bowl, open at the southeast end and topographically reflected by Pleasant Valley. The oil-bearing measures of the Westside field occupy. the western and wider half of this bowl, outcropping along a curving but in general north-south strip 10 miles long at the border of the hills and dipping toward the center of the valley at an average angle of about $12^{\circ}$. A few minor wrinkles affect the strata, but the monoclinal structure dominates. This structure is noteworthy, inasmuch as the monocline forms the reservoir for one of the most productive oil fields known. It is different from the structure found in the majority of oil fields, including that which dominates the adjoining Eastside or Coalinga anticline field. Some points bearing on the effect of the structure on the accumulation of oil in this field, particularly the presence of the anticline to the east, have been mentioned above in the general discussion of the occurrence of oil along the San Joaquin Valley.

The formations outcropping along the hills west of Pleasant Valley and dipping beneath that valley are in the order of superposition, the Panoche formation (Upper Cretaceous), which was described in the Coalinga report as part of the Knoxville-Chico rocks; the Tejon formation (upper Eocene); the Kreyenhagen shale (Oligocene?), tentatively described in the Coalinga report as the upper member of the Tejon, and known by the oil operators as "the brown shale underlying the oil measures"; the Vaqueros formation (lower 
Miocene); the Santa Margarita (?) formation (middle Miocene); the Jacalitos formation (upper Miocene); and the Etchegoin formation (upper Miocene and Pliocene?). In addition to these, the Moreno formation (Upper Cretaceous), described in the Coalinga report as the purple shale or uppermost member of the Knoxville-Chico rocks, outcrops along the hills northwest of Pleasant Valley, but it gradually narrows southwestward and disappears north of Los Gatos Creek. The only other formation besides these which is exposed along the Coalinga anticline to the north is the Martinez (?) (lower Eocene), tentatively described in the Coalinga report as the clays in the lower part of the Tejon formation. This formation disappears in the vicinity of Oil City and does not reappear to the south. The belts of outcrop of all the Tertiary formations are narrow and discontinuous, it being evident that most of the formations suffered erosion prior to the deposition of the succeeding beds. This is explained on the supposition that the area now forming the western border of Pleasant Valley was fairly close to the western shore line during much of the time that deposition was going on in Tertiary seas in this region and was subject to the oscillations above and below sea level that would naturally characterize such a shore-line belt. In accordance with this supposition it is believed probable that the formations gradually become more continuous and more completely represented outward beneath the valley; and for the same reason it is believed that the two formations present in the Eastside field but not outcropping far southwest of that field, namely, the Moreno (Upper Cretaceous) and the Martinez (?) (lower Eocene), are probably present beneath the Westside field. As will be pointed out presently, this geologic deduction is of significance in its bearing on the economic problems to be discussed. The formations present beneath this field, including the two last named, which are supposedly present, are shown in the hypothetical section, figure 4.

The oil measures so far exploited along the flank of the Coalinga syncline lie in the lower part and at the base of the Miocene series. Owing to the inconstancy of the formations the beds in which the oil occurs are not the same in different parts of the area, being in some places Vaqueros and elsewhere Santa Margarita (?) or Jacalitos, but in each place these beds form the lowest part of the Miocene series there present. The petroleum heretofore produced is believed to have risen from the Kreyenhagen shale, just as it has risen along the Coalinga anticline, and collected in the overlying sandy beds of the Miocene, irrespective of what part of the Miocene might overlie the Kreyenhagen in any particular locality. Inasmuch as the Santa Margarita (?) and Jacalitos formations completely overlap the Vaqueros in a part of the field and rest upon the Kreyenhagen shale, they constitute the productive zone there. This condition 
prevails through the central parts of the field within about a mile from the outcrop of these formations. In the north and south ends of the field and down the dip a mile or two east of the outcrop the Vaqueros formation enters in between the Kreyenhagen shale and the later Miocene beds, the Santa Margarita (?) or Jacalitos, as the case may be, and becomes productive. In proportion as the Vaqueros formation thickens and increases the distance between the "brown shale" (the Kreyenhagen) and the later Miocene beds, the productivity of the later Miocene beds decreases until they become barren. This fact gives one of the best arguments in favor of the supposition that the Kreyenhagen was the source of the oil. The thickness of beds above the shale through which the oil has penetrated ranges from, a few hundred feet to 1,100 feet. Productive zones occur chiefly within the lower 400 to 700 feet of the Miocene. The oil is for the most part a black to brown asphalt oil ranging in specific gravity from 0.9859 to 0.9333 ( $12^{\circ}$ to $20^{\circ}$ Baumé), but locally oil as light as $0.8974\left(26^{\circ}\right.$ Baumé) is obtained.

The evidences of oil at the surface which led to the development of the Westside field occur in the hills west of Coalinga, where the

- Kreyenhagen shale and the beds forming the lower part of the Miocene series exposed may be found impregnated or stained with oil here and there along their outcrops for a distance of over 3 miles. The stretch of hills through which these surface indications of oil appear extends from the San Joaquin Valley coal mine southward within a short distance of Alcalde Canyon. At the San Joaquin Valley coal mine the siliceous shale that overlies the sandstone of the Tejon and is believed to represent the Kreyenhagen shale is stained with petroleum, very much as it is along the Coalinga anticline and elsewhere. The Vaqueros formation is lacking here, and the shale is unconformably overlain by sandy and conglomeratic beds belonging to the Santa Margarita (?) formation, which are likewise oil stained. At a point not far to the south the Vaqueros appears at the surface between the Kreyenhagen shale and the later Miocene beds, and a little farther south it entirely overlaps the Kreyenhagen and Tejon formations and rests upon the Panoche formation (Cretaceous). Consequently the Vaqueros is the oil-bearing formation from that point southward, and its outcrops give evidence of the formation being highly charged with petroleum. The most pronounced signs of oil occur in this formation $3 \frac{1}{2}$ miles west of Coalinga, near its contact with the Panoche formation, notably in the SE. $\frac{1}{4}$ sec. $2, \mathrm{~T}$. $21 \mathrm{~S} .$, R. 14 E. There the basal beds of the Vaqueros are soaked with oil, and long before the development of the productive territory to the east, down the dip of the beds, tunnels were run into the hills in this vicinity in the attempt to obtain paying quantities of the seepage oil. Petroleum obtained in this way is said to have been used 
locally for lubricating in the early days. A mile or so farther south discolorations of the Vaqueros beds, probably due to petroleum, are noticeable along a fault line passing through sec. 12, T. 21 S., R. 14 E.

POSSIBLE DEEP SANDS.

The principal question to be taken up here is that of the possible existence under the Westside field of one or more oil sands deeper than any heretofore tapped by the wells. It has already been shown in the discussion of the Eastside field that there occur in that field and in the region to the north two formations, consisting of diatomaceous and foraminiferal shale, in which oil is believed to have originated. These are the shales of the Moreno formation and the Kreyenhagen shale. The oils furnished by these two shales are very different in character, that occurring in the Miocene formations, and supposedly derived from the Kreyenhagen, being a typical asphalt oil, whereas that occurring in the Moreno. (Upper Cretaceous) and in the overlying Martinez (?) and Tejon (Eocene) contains a considerable amount of paraffin wax. All the oil so far produced in the Westside field comes from the Miocene formations just above the Kreyenhagen shale, and in general is an asphalt oil similar to that found in an analogous position in the Eastside field. The possibility of the presence of a productive deeper sand, such as that in the Martinez (?) or Tejon formations (Eocene) found along the Coalinga anticline has suggested itself to many of the operators in the field, and it is hoped that a discussion of the evidence bearing on this possibility may be of service. The main conclusions are represented graphically in the hypothetical section through the Westside field shown in figure 4.

In the opinion of the writers the fundamental question bearing on this possibility is whether or not the Moreno formation (Upper Cretaceous), the oil-bearing formation of the Oil City area, is present beneath the Westside field. The reason for this opinion is that the Moreno formation is believed to be the source of the oil found within it and the overlying Martinez (?) or Tejon formations (Eocene) in the Eastside field and because it is the only formation below the Eocene known to contain any considerable amount of oil. Therefore if the Moreno formation is not present beneath the Westside field it does not seem likely that the beds below the Miocene contain much oil, unless the oil had originated in the Eocene formations themselves, which appears improbable, or had descended from the Kreyenhagen shale, which it does not seem to have done in any important quantity along the anticline to the north. On the other hand, if the Moreno formation is present beneath this field, it is believed that the chances are in favor of its containing oil, as it does at Oil City, and contributing some of the oil to the overlying sandy beds comprised in the Martinez (?) or Tejon formations. It would 
thus furnish two or more oil-bearing zones offering a good prospect of being productive at horizons many hundred feet below those from which the oil has heretofore been obtained. Moreover, the oil in these lower zones would probably be a paraffinbearing oil of light gravity.

The writers incline to the belief that the Moreno formation continues southward under the cover of later formations from the area north of Los Gatos Creek, where it is last exposed, and extends beneath Pleasant Valley. In the Eastside field the fact that the Moreno outcrops along the axis of the Coalinga anticline made it possible to state with practical certainty, before any attempt had been made to drill below the oil sands of the Vaqueros, that if the wells were put down to a sufficient depth they would strike the Moreno formation and penetrate the measures which are productive in the Oil City area, and which are included and associated with that formation. In the Westside field, however, the case is different, and there is by no means the same assurance that this formation would be encountered at all or that either the Martinez (?) or

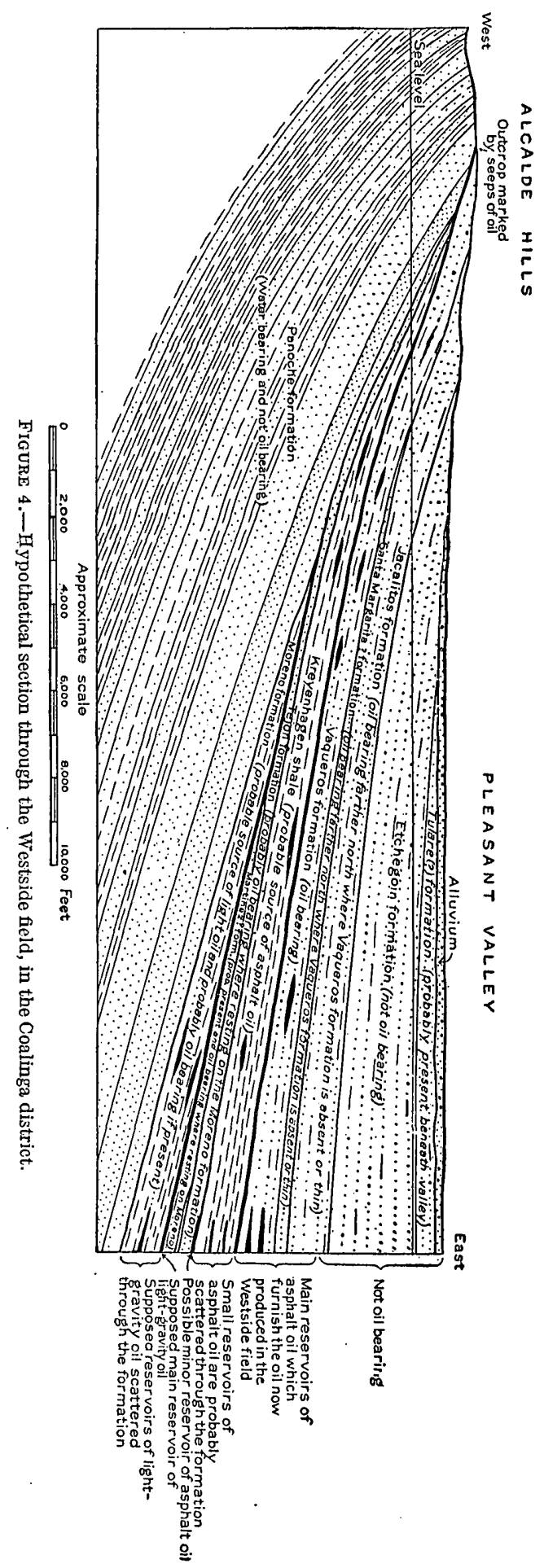


Tejon formations, one or both of which are oil bearing along the Coalinga anticline, would have any source from which to derive oil beneath the west flank of the syncline. The fact that the Moreno formation outcrops for several miles southwest of Oil City, although decidedly thinner in that direction, makes it highly probable that this formation underlies the northern part of the Westside field, and hence the chance of striking it there is excellent. Farther south its presence is more hypothetical.

The reasons for believing it probable that the Moreno formation underlies Pleasant Valley are as follows:

1. It is well developed in the northern part of the Coalinga district, and it has proved very persistent from that field northwestward for a distance of over 100 miles. It therefore more probably than not continues farther south, at least for a few miles, and does not pinch out abruptly.

2. The Tertiary formations overlap lower and lower beds of the Cretaceous southwestward from Oil City, and the Cretaceous beds strike beneath the Tertiary. Moreover, almost all the formations southwestward from Oil City are overlapped to some extent by the later ones. These facts show that the disappearance of the Moreno formation along the edge of the hills is not a feature peculiar to it. This evidence, coupled with the indications obtained in the wells of the greater completeness of all the Miocerie formations out at some distance from the hills than along the line of outcrop, gives ground for believing that the failure of the Moreno to outcrop from beneath the overlapping Tertiary does not necessarily imply its absence beneath Pleasant Valley. These facts indicate that the formation, if present, is more apt to be well developed out under the valley than near the hills.

Granted that the Moreno formation probably underlies the Westside field, the next question that arises is whether it is oil bearing. No direct evidence certainly bearing on this question is available, - but it is believed that the structure of this lower oil-producing shale, if it is present, is practically the same as that of the higher petroleumbearing Kreyenhagen shale, and that there is nearly as much reason for the lower to be oil bearing as the upper. Both are petroliferous in the Eastside field, a few miles to the north, and the upper shale carries oil here. Hence it would be surprising if the lower shale were not oil bearing here also. The structural features and general situation of the Westside field are analogous in some respects to those in The Vallecitos, to be described later. There the Moreno formation outcrops and is found oily. If the formation is present at all in the Westside field, the conditions are believed to be much more favorable for its containing petroleum here than they are in The Vallecitos. 
If oil were present in a formation concealed below the Eocene formations, the surface evidence of it might be expected to occur in the outcrop of the Eocene formations themselves, for the reason that the oil would be expected to rise along the base of these formations, and might show at the surface, just as it does in the Vaqueros formation west of Coalinga, where that formation conceals the unconformably underlying Kreyenhagen. No signs of oil were noted in the sandy beds of the Tejon (Eocene), which outcrop in contact with the sandstone of the Panoche formation (Upper Cretaceous) from the San Joaquin Valley coal mine northward, although these beds are of a character which would favor the collection and migration of oil. This evidence is at best only negative, however, and can not have much weight, for the reason that the underlying oil-bearing shale is supposed not to be well developed for at least a mile or two out from the outcrop of the Tejon. Southward from the vicinity of the San Joaquin coal mine the Tejon disappears beneath the Vaqueros. Therefore, in that part of the field, the horizon at which the supposed oil from a formation below the Eocene would appear at the surface, if at all, would be at the base of the Vaqueros, which is the same horizon as that where the higher oil would seep out.

Several water wells in the southern part of the field have gone to depths of many hundred feet below the lowest Miocene oil sand without encountering oil, but so far as known all the wells that have passed through the Miocene and have penetrated older strata have been near the edge of the hills, where the formations between the Vaqueros (lower Miocene) sands and the Panoche (Upper Cretaceous) were either thin or absent, so that they gave no test of the possibilities of the formations which are supposed to form a considerable thickness between the Vaqueros and Panoche farther from the outcrops.

The next question relates to the probable zones of accumulation of the oil and their depth, if such a supposed oil-producing shale extends beneath the Westside field. The answer is that the oil would presumably collect here, as it does along the Coalinga anticline to the north, in the Moreno formation and in the overlying Martinez (?) or Tejon (Eocene). The Eocene formations would probably form the better reservoir, owing to (a) their unconformable position upon the Moreno, which would tend to make them the collecting ground for oil escaping from that formation; $(b)$ the presence in them of porous sand beds, likely to be more constant and better reservoirs than would be formed in the Moreno; (c) their probable greater extent beneath the field; and $(d)$ their lesser depth, as a result of which they would be accessible over a greater area. The Tejon formation (Eocene) exposed along the hills consists of 200 or 300 feet of sandy beds with some intermingled shale, clay, and coal. It would form $81281^{\circ}-$ Bull. $603-15-11$ 
an excellent reservoir for oil and may in reality rest upon the Moreno formation beneath Pleasant Valley and occupy the position most favorable for receiving the oil from that formation. It is not unlikely, however, that the Martinez (?) formation (lower Eocene) is present below the Tejon under the valley, in which case it would be the more likely receptacle. The formations below the Miocene oil sands which it would be necessary to pass through to determine the presence and possibilities of the supposed lower sands would therefore be as follows:

1. The Kreyenhagen shale, which might be from 300 to 900 feet thick. It is composed mainly of brown and white shale, with possibly minor streaks of sand that might afford slight quantities of oil. Such oil would probably be of the same general type as that found in the overlying Miocene sands. Owing to the fine texture of the shale and the small amount of interbedded sand it is not thought likely to afford a good reservoir.

2. The Tejon, probably 200 to 300 feet thick and mainly sandy. This might contain light oil, especially if no beds of the Martinez (?) formation entered between it and the oil shale of the Moreno. It is probable that this formation may contain some oil that has entered it from the overlying shale, and this oil alone might possibly be sufficient to afford a small production from the Eocene in places. The likelihood is, however, that most of the oil from the Kreyenhagen shale migrated upward into the Miocene formations instead of down into the Tejon. If the Tejon is formed of porous beds, it would not be surprising to find a mingling of the light oil from below and the asphalt oil from above in the upper portion of the Tejon.

3. The Martinez (?) formation, if present. It might vary in thickness up to 600 feet or more. If it is similar to the formation in the Eastside field it consists largely of dark clayey beds with occasional sandstone layers. The lower part would be expected to furnish the main productive beds if the shale of the Moreno formation were present below and were oil bearing.

4. The Moreno formation, if present. This formation might have any thickness up to 1,000 feet or more. It probably consists of dark shale, with occasional "hard shells" and streaks of sandstone and irrregularly distributed, fairly thick lenses of oil sand. Beds of sand carrying light-gravity oil containing paraffin wax might be encountered at almost any point in the formation.

Below this formation the unproductive sandstone and dark shale of the Panoche formation would be encountered.

Owing to lack of evidence, the distribution of the formations beneath the Westside field is only conjectural, and definite figures as to the depth that it would be necessary to drill to reach the supposed light-oil sands can not be given. In general it is believed that both the Miocene and pre-Miocene formations gradually thicken beneath 
the valley eastward from the hills, so that the minimum estimates of thickness of the formations given above apply near the hills in that part of the field south of Los Gatos Creek; whereas the maximum estimates would be safer to adopt for the beds underlying the valley at a considerable distance out from the hills and in that part of the field north of Los. Gatos Creek. It is estimated that an adequate test of the possibilities of the Tejon and Martinez (?) formations could be made by drilling 1,500 feet below the lowest Miocene oil sand. If this test were successful, it would point to the presence of oil-bearing beds in the uppermost Cretaceous still farther down, but if unsuccessful it would go a long way toward showing that the shale of the Moreno formation was either absent or barren. To make a complete test of the oil shale of the Moreno (Upper Cretaceous), if present, a well would have to go at least a thousand feet deeper.

\section{CONCLUSION.}

In conclusion it must be stated again that the geologic conditions of this region leave us largely in the dark as to whether or not promising oil sands occur below the Miocene sands at present producing in the Westside field. The Moreno formation is known to pass beneath the Coalinga anticline, in the Eastside field, and is there supposed, together with the overlying Martinez (?) and Tejon formations, to be oil bearing down to a great depth. But southward from that field the degree of certainty grows less and less. The Moreno formation is pretty certainly present around the head of the Coalinga syncline beneath the northern part of the Westside field, but through the greater part of this field the conditions are different from those in the Eastside field, and the presence of one or more oil-bearing formations below the Miocene is by no means so certain as along the Coalinga anticline. Nevertheless, for the reasons already discussed, there is a good chance that sands capable of producing light oil of a different character from that now yielded by the wells underlie the known productive formations of the Westside field, and this chance is well worth testing.

In the northern part of the Westside field, north of Los Gatos Creek, a well to test the deeper formations might reasonably be put down along the hills in the neighborhood of the other wells, prepared to go to a depth of 1,000 to 2,500 feet below the lowest Miocene sand. South of Los Gatos Creek, owing to the structural conditions above outlined, it is more likely that the supposed lower sands would be found under the valley some distance from the hills than near the hills, and the development of such sands would be almost entirely a matter of deep drilling. In the opinion of the writers a test well to be most favorably placed should be out in the valley $1 \frac{1}{2}$ or 2 miles east of the outcrop of the lowest Miocene beds exposed and should go to a depth of 3,000 to 3,500 feet to test the possibilities of the Martinez (?) 
and Tejon formations and of at least 4,000 feet to make a complete test of the possible sands in the Moreno. Owing to the numerous doubtful factors these and other estimates of thickness given in this discussion are only approximate, and the depth to which it would be necessary or advisable to sink a well would depend to a considerable extent upon the facts disclosed in the process of drilling.

OUTER FOOTHILLS AND VALLEY BORDER FROM THE NORTH EDGE OF THE COALINGA FIELD TO TUMEY GULCH.

In the discussion of the northern limit of the Coalinga field an idea has already been given of the structure prevailing along the hills from that field northwestward. The geologic section shows a continuation of the formations that occur in the Coalinga field, but there is this vital difference in the structure, that the beds are not arched but instead are merely tilted at a steep angle toward the San Joaquin Valley, their truncated edges forming the surface of the hills. They strike uniformly northwest, parallel with the general trend of the hills, and constitute a portion of the flank of the major fold represented by the Diablo Range as a whole. In one area only is there a suggestion of a fold, and that is in the Ciervo Hills north of Cantua Creek, where the Ciervo anticline, a pronounced fold farther back in the older formations, exerts a faint influence upon the Kreyenhagen shale and overlying Miocene formations, which shows itself in a slight bending of the strike that causes the outward bowing of the hills north of Cantua Creek. This change of strike is too slight to be treated as a fold or to have any effect of economic importance. 'It gives an interesting illustration, however, of an embryonic fold of the type of the Coalinga anticline, which might have had an influence, like that ascribed to the Coalinga anticline, in retaining the oil, if its effect upon the Tertiary beds had been more extensive.

The formations exposed in the area under consideration are the Kreyenhagen shale and the overlying Miocene formations, which are predominantly sandstone and sandy beds. From the northern edge of the Coalinga field at the north line of T. $19 \mathrm{~S}$. northwestward to Cantua Creek the Kreyenhagen shale and Vaqueros formation dip ordinarily $30^{\circ}-40^{\circ} \mathrm{NE}$. The inclination of the later Miocene strata is somewhat less and decreases progressively toward the San Joaquin Valley. From Cantua Creek northwestward to Tumey Gulch the same general structure continues, but the area may be divided into three lengthwise zones-one of low dips, $5^{\circ}$ to $25^{\circ}$, on the higher hills a few miles back from the valley; a middle zone of sharply folded and locally faulted strata which dip from $30^{\circ}$ up to vertical and average perhaps $50^{\circ}$ or $60^{\circ}$, where the higher hills break to the lower hills; and a third zone formed by the belt of lower hills, 2 or 3 
miles wide, in which the later Miocene beds decline gradually in dip outward toward the valley from about $40^{\circ}$ to as low as $7^{\circ}$. The structure of the first zone affects mainly the Kreyenhagen shale and a local thin covering of Vaqueros. It is produced by the dying out of the Ciervo anticline. The low-dipping beds in this zone bend abruptly northwestward into the steep dips of the second zone along the line designated on the map Monocline Ridge. They thus afford an excellent example of a monoclinal fold. The main body of the steep beds that are exposed consists of sandstone of the Vaqueros formation, which formerly arched over the axis of the flexure and covered the low-dipping shale to the west. Now, however, the lowdipping sheet of Vaqueros appears only here and there upon the shale, having been in most places detached by erosion from the areas of steeply inclined beds. A glance at the map and at section $\mathrm{E}-\mathrm{E}^{\prime}$ (Pl. I) will indicate the details of structure along this foothill belt.

If any oil existed in this belt, the place to look for accumulations of it would be in sandstone of the Vaqueros formation overlying the Kreyenhagen shale, in a position analogous to that of the oil sands in the Coalinga field. Indications would also be looked for in the shale. The later Miocene formations would offer no basis for expecting it. Three features of prime importance in relation to the question of finding oil impress the observer in this area. They are the entire absence of definite surface indications of petroleum; the lack of folds to break the regularity of the structure, and the steepness of the dips in that portion of the section where oil would be expected if at all, namely, where a thick body of sand overlies the shale. As regards the first feature, the beds nowhere in this area show any signs of containing an appreciable amount of oil. The nearest approach to such an indication is the local discoloration of the white diatomaceous shale, similar to discoloration noted in it at other places where it is known to be oil bearing, suggesting the probability that it once was impregnated with petroleum and may still have traces of it locally. There can be no doubt that if oil in any quantity were present at depths in such steeply dipping strata, in beds as porous as those of the Vaqueros, it would appear at least locally at the surface and form seeps and asphaltic deposits at the。 exposed edges of the beds, as it does in less steeply inclined strata in many places through the Coalinga district, around The Vallecitos, and elsewhere.

It is not at all unlikely that petroleum once existed in these beds. So far as the conditions for the original production of oil are concerned, no reason is known why they should not have been just as favorable in this area as they were in the Coalinga district. In fact 
the conditions that are believed to have been essential are the same in both regions. But considering the structure of this foothill belt it would be rather a cause for surprise if most of the oil supposed to have been originally present had not accumulated higher up the dip of the beds, previous to their removal by erosion from the crest of the Coalinga and Ciervo anticlines, which they must once have covered.

The wells that have been drilled for oil in this foothill belt northwest of the north line of T. 19 S., R. 15 E., are the Tavern Oil.Co.'s well, in sec. 34, T. 18 S., R. 15 E.; the Peerless Consolidated well, in the SW. $\frac{1}{4}$ sec. 28 , T. 18 S., R. 15 E.; the Big Shell well, in the SW. $\frac{1}{4}$ seo. 20, T. 18 S., R. 15 E.; and a well in sec. 34 , T. 16 S., R. 13 E. Since the writers left the field the Standard Oil Co. started a well in the southwest corner of sec. 27, T. 18 S., R. 15 E. This well was still being drilled in May, 1915. Of these the Tavern and Big Shell penetrated the Vaqueros without obtaining any oil and were adequate tests of the area in which they were drilled. The Peerless did not go to a sufficient depth to afford a test. The fourth well mentioned was not advantageously located to test the sands of the Vaqueros formation, nor did it go to any considerable depth. In addition to these wells two derricks were erected in sec. 28 and one in sec. 20 , T. 18 S., R. 15 E., but drilling was never begun.

The Tavern well started on Domengine Creek about a mile northwest of the Imperial wells, at about the base of the Jacalitos formation and the top of the Santa Margarita (?) formation. At this point the monocline dips $30^{\circ}$ to $35^{\circ}$. The well penetrated beds containing large oysters, evidently the lower portion of the Santa Margarita (?) formation, at 660 feet; found sand containing water from 671 to 922 feet; red shale (doubtless representing the Big Blue member) from 922 to 1,065 feet; sand containing water from 1,065 to 1,566 feet, evidently the upper portion of the Vaqueros formation; a "showing" of oil at 1,656 feet; water sand from 1,790 to 1,804 feet; and the base of the Vaqueros 150 or 200 feet lower, without obtaining any oil. It went below the Vaqueros for several hundred feet into the Kreyenhagen shale, finding a little gas but nothing more.

The Peerless well started at a slightly higher geologic horizon, oabout á mile farther north, but after passing through the oyster beds of the Santa Margarita (?) it stopped in the reddish beds of the Big Blue member at a depth of 1,660 feet without testing the basal part of the Vaqueros, where oil was to have been expected, if at all.

The Big Shell well started at about the top of the Santa Margarita (?) formation, a mile northwest of Domengine's place, where the monocline dips about $35^{\circ}$. It penetrated oyster beds of that formation at 600 feet and went to a depth of 1,700 feet, passing a short distance into the Kreyenhagen shale without finding oil. 
This is the northernmost test that has been made of the Vaqueros along the monocline at the edge of the San Joaquin Valley. The results obtained in this and the Tavern well represent what it is believed would be the result in any well drilled along this monocline farther north.

The fourth well above mentioned was situated in sec. 34, T. 16 S., R. 13 E., in a very out of the way and comparatively inaccessible place on the northeast flank of the Ciervo Hills and was abandoned many years ago. It is not known what led to its location at this point nor to what extent operations progressed. It is situated on the Kreyenhagen shale and would have had to go to a depth of several thousand feet to reach the base of the Eocene and top of the Moreno, the first formation appearing to offer any reasonable promise of yielding oil. The possibilities of this lower formation will be discussed in connection with the Ciervo anticline (pp. 178-181).

The conclusion regarding the monoclinal belt under consideration is that it does not offer any promise as an oil-producing tract. The considerations pointing to this conclusion are numerous, including the unfavorable results obtained in certain wells, the lack of surface indications of oil, the unfavorable structure, and the probability that any oil that may have been originally present has escaped through the eroded edges of the formation. As regards the border of the San Joaquin Valley, beyond the edge of the foothills, it is impossible to entertain any favorable opinion, for the reason that there is no indication whatever that transverse folds extend out under the valley from this portion of the Diablo Range and because the dip of the Vaqueros formation carries it to too great a depth beneath the valley for it to be profitably reached even if it contained oil.

INNER FOOTHILLS FROM THE COALINGA DISTRICT TO NEW IDRIA AND BEYOND.

The inner portion of the foothills northeast of the Coalinga district has a structure similar to the western part of the parallel outer belt just described and would have been described with that outer belt but for the fact that the Moreno formation (Upper Cretaceous), which will be the main subject of discussion for this area, is separated from the formations of the outer belt by a considerable thickness of barren strata and is more easily described by itself.

The outcrop of the Moreno formation in the monocline of Cretaceous beds may be traced continuously along the northeast base of the mountains from Oil City, in the Coalinga district, to New Idria and beyond, a distance of 30 miles or more. The underlying sandstones of the Panoche formation form the face of the mountains, and the stratigraphically overlying shale of the Moreno forms a belt of low relief in front of the main mountain ridges. The shale of the Moreno 
dips rather steeply northeastward throughout the belt. The angle varies between $20^{\circ}$ and the vertical, but it is only locally as low as $20^{\circ}$, the usual dip being considerably steeper. The shale has been subjected to much crushing and is traversed at many places by local faults, which, however, were not traced in the field.

The shale is known to contain a large amount of petroleum in the Oil City field, at the southeast end of the belt above described. It furnishes the light-gravity oil of that field in wells that are drilled into it near the axis of the Coalinga anticline. At several places between Coalinga and New Idria the shale and the limestone nodules that it contains give a faint odor of petroleum when freshly fractured, a fact, which together with less positive indications such as discoloration, warrants the conclusion that the beds were at one time impregnated with oil throughout their extent.

I In the oil field along the Coalinga anticline the Martinez (?) and Tejon formations, which overlie the. Moreno, are likewise oil bearing, as is brought out in the discussion of that field. Along the monocline to the northeast, here under consideration, both the Martinez (?) and Tejon formations continue, although undergoing significant variations. No surface evidences of oil are known in them, nor have any wells been drilled into them so as to afford further evidence in regard to their contents. For several miles northwest of the north edge of the Coalinga field the Eocene formations maintain a similar lithologic character, but the thickness of the clay shale in the Martinez (?) or lower portion of the series increases compared with the thickness found in the wells that penetrate it in the Coalinga field. Beyond Salt Creek the Martinez is mainly sandy, the huge lens of the Cantua sandstone member overlying the Moreno formation from Salt Creek northwestward.

In Mancillas Canyon, 6 miles northeast of New Idria, in a belt of shale believed to be the continuation of the Moreno formation, there is said to have been formerly a strong seepage of oil, but when the locality was visited by the writers the outcrops were covered by landslides. The Fresno-San Benito well was drilled at this place, near the center of the line between secs. 20 and 21 , T. 17 S., R. 11 E., about eight years ago to a depth of several hundred feet, without success. The beds penetrated by the drill are tilted, crushed, and faulted, and the stratigraphic relations are not clear. The conditions for the accumulation of oil at this locality are poor.

One other well has been drilled along this belt of shale and has furnished a satisfactory test of an area that is probably as favorable as any other along the belt under consideration. This is the Cantua well, situated in a branch ravine of Cantua Creek on the east side of sec. 35, T. 17 S., R. 13 E. It started near the top of the Moreno formation, where the monocline is regular and dips at an angle of $25^{\circ}$ to $30^{\circ}$, 
and penetrated the sands at the base of the shale at a depth of a little over 2,000 feet, without obtaining oil. The following $\log$ of the well, which was drilled in 1908 and 1909, was kindly furnished by Mr. Shirley C. Ward, of Los Angeles, and Mr. R. H. McCreary, of Hanford:

Log of Cantua Oil Co.'s well, in sec. 35, T. 17 S., R. 19 E.

\begin{tabular}{|c|c|c|c|c|c|}
\hline & $\begin{array}{l}\text { Thick- } \\
\text { ness. }\end{array}$ & Depth. & & $\begin{array}{l}\text { Thick- } \\
\text { ness. }\end{array}$ & Depth. \\
\hline & Feet. & Feet. & & Feet. & \\
\hline \multirow{2}{*}{$\begin{array}{l}\text { Dark-brown shale............ } \\
\text { Dark-brown shale with a lit- } \\
\text { tle water at } 500 \text { feet.......... }\end{array}$} & & $0-\quad 90$ & Hard gray sand with gas. & 15 & $1,660-1,675$ \\
\hline & 55 & $90-145$ & Hard sand shells and soit & & \\
\hline Blue sandy shale.............. & 56.5 & $145-710$ & 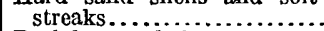 & 14 & $1,683-1,697$ \\
\hline Dark-brown shale. & 30 & $710-740$ & Dark-brown shale.. & 3 & $1,697-1,700$ \\
\hline Blue sandy shale.. & 33 & $740-773$ & Hard shell........ & 2 & $1,700-1,702$ \\
\hline White shale........ & 27 & $773-800$ & Dark-brown shale with thin & & \\
\hline Brown shale.. & 58 & $800-858$ & 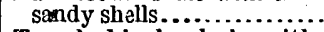 & 63 & $1,702-1,765$ \\
\hline White shale.. & 10 & $858-868$ & Tough black shale with & & \\
\hline Brov & 87 & $868-955$ & considerable gas............ & 25 & $1,765-1,790$ \\
\hline 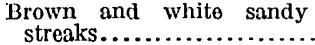 & & $955-965$ & 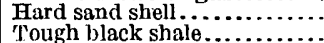 & $\begin{array}{l}2 \\
8\end{array}$ & $\begin{array}{l}1,790-1,792 \\
1,792-1,800\end{array}$ \\
\hline Hard sand shell......... & 135 & $\begin{array}{l}955- \\
965-1,100\end{array}$ & Very soft black shale... & 20 & $1,800-1,820$ \\
\hline Dark-brown shale.. & 4 & $1,100-1,104$ & Hard blue sand shell; & & \\
\hline White shale. & 29 & $1,104-1,133$ & "showing" of gas and & & \\
\hline Broy & 10 . & $1,133-1,143$ & a few "colors" of oll. & 5 & $1,820-1,825$ \\
\hline ad brown shale & 5 & $1,143-1,148$ & Black shale.. & 14 & $1,825-1,839$ \\
\hline Sand & 147 & $1,148-1,295$ & Hard blue sand shell; no gas or & & \\
\hline Bro & 7 & $1,295-1,302$ & 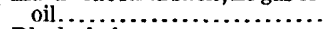 & 7 & $1,839-1,846$ \\
\hline Hard sandy shale. & 23 & $1,302-1,325$ & Black shale. & 13 & $1,846-1,859$ \\
\hline Brown and light shalo. & 5 & $1,325-1,330$ & Black sandy shale; strong & & \\
\hline Sand with gas; I & 25 & $1,330-1,355$ & "showing" of gas.. & 53 & $1,859-1,912$ \\
\hline Brown and light shale & & & White sandy shale.... & 10 & $1,912-1,922$ \\
\hline with small pockets of & & & Hard sand shell........ & & $1,922-1,929$ \\
\hline gas at 1,435 and 1,450 & & & Sand like that outcropping & & \\
\hline Thin hard slieil ar & & $\begin{array}{l}1,300-1,500 \\
1,500-1,502\end{array}$ & $\begin{array}{l}\text { on Cantuacreek. No signs } \\
\text { of oil or gas in sand but a }\end{array}$ & & \\
\hline & 5 & $1,502-1,507$ & very strong "showing" of & & \\
\hline Sand with gas & 13 & $1,507-1,520$ & & 76 & $1,929-2,005$ \\
\hline Lig & 140 & $1,520-$ & & & \\
\hline
\end{tabular}

The conclusion regarding the area under discussion is similar to that expressed as to the outer foothill area, and it is reached on practically the same grounds, which do not need to be repeated. The chance of obtaining an economically important quantity of oil from the Moreno formation or the overlying beds along this monocline is very slight.

\section{VALLECITOS DISTRICT.}

GENERAL FEATURES.

The Vallecitos offers an excellent example of a completely inclosed synclinal basin. The topography roughly reflects the structure, so that it is at once a structural and topographic basin. The valley is a little over 10 miles long from east-southeast to west-northwest (not including the valley of Pimental Creek on the west, which is really a continuation of it) and has an average width of about 2 miles between the bases of the steeper hill slopes bounding it. It is divided into an eastern and a western part by a low drainage divide and is drained by two intermittent streams that have cut deep canyons northward across the structure at either end of the valley. 
The two divisions of the basin account for the name, which means "the little valleys." The structural trough is produced by the Cretaceous and Tertiary formations dipping rather steeply southward on the north side and even more steeply northward on the south side, the axis of the trough corresponding approximately to the bottom of the valley. On the east the trough is closed where the beds circle around the end of the valley east of San Carlos Creek and dip at a moderate angle westward. Toward the west end the sides of the trough gradually steepen, but the syncline continues up the valley of Pimental Creek.

The formations involved in this syncline are as follows: $(a)$ The Panoche formation, mainly concretionary sandstone, which forms the main mass of the Griswold Hills, on the north, and appears on the main ridge of the Diablo Range, to the south; $(b)$ the Moreno formation, which on the north occurs along a belt of extremely variable width and in places hardly traceable and which owing to faulting is not recognizable with certainty in the western portion of the southern flank; (c) the Martinez (?) formation, of mingled concretionary sandstone and clay shale, which is so much like some of the other formations that its identification and delimitation are in many places difficult; $(d)$ the Tejon formation, mostly of white sandstone and only locally traceable; $(e)$ the Kreyenhagen shale, soft white diatomaceous shale, and hard siliceous shale occurring pretty continuously on both flanks; $(f)$ the Vaqueros (lower Miocene), which encircles the valley and forms the steep sandstone hills bordering the lower slopes; and $(g)$ the Jacalitos and Etchegoin formations, composed largely of black, red, and green clays with interbedded sand and gravels, representing the later Miocene and occupying the core of the syncline. Descriptions of the thickness, distribution, and composition of these formations will be found in the separate sections of this report devoted to them. Of these formations those of chief importance with relation to oil are, as in the Coalinga district, the diatomaceous shales of the Moreno and the Kreyenhagen and the sandy beds overlying them. Seeps occur in the Moreno north of the west end of The Vallecitos and in supposedly equivalent beds in Mancillas Canyon south of the valley. (See p. 123.) Seeps and indications of oil occur in the Kreyenhagen shale at numerous places along the south flank of the syncline and also at its east end. In addition surface indications of oil occur locally in the Vaqueros and at one place in the clays of the Jacalitos and Etchegoin formations. It is therefore evident that petroleum is present and pretty well distributed along the flanks of this fold, and the main question to decide is as to the amount that may be recoverable. In order to discuss the conditions and the evidence bearing on this point somewhat more in detail, the district will be divided into two parts-the steeply tilted 
south flank of the fold and the similarly steep north flank which merges with the more gently tilted east end of the syncline. For a more detailed discussion of the surface evidences of oil the reader is referred to the previous section of this report dealing with the seeps and other indications offered by the various formations (pp. 123-136).

\section{SOUTH FLANK OF THE VALLECITOS SYNCLINE.}

Along the south side of The Vallecitos the mountains and descending ridges are formed by a continuous monocline dipping steeply toward the valley. This monocline is the southern flank of the Vallecitos syncline. From San Carlos Creek, at the east end of The Vallecitos, it strikes westward for about 5 miles and then bends at an angle of about $35^{\circ}$ and strikes northwestward to the west end of the valley. Beyond that place the same steep monocline continues in a similar direction along the south side of the valley of Pimental Creek. The area of chief interest in the present connection is the belt of Tertiary strata at the outer edge of the foothills. These beds consist of the Kreyenhagen shale and the sandstone and shale of the Vaqueros formation at the edge of the hills, overlain by the thick variegated clay of the Jacalitos and Etchegoin formations.

The dip of the Vaqueros and older beds varies from about $40^{\circ}$ to the vertical. For much of the way the formations are overturned along the front of the hills and appear to dip southward. The overturning, however, is not believed to extend very far below the surface. The overlying Jacalitos and Etchegoin formations are likewise steep along their contact with the Vaqueros, standing vertically in places and nowhere dipping less than $30^{\circ}$. The dip decreases, however, northward toward the axis of the Vallecitos syncline.

The Kreyenhagen shale and the Vaqueros are oily practically throughout their extent along the south side of The Vallecitos, the siliceous diatomaceous shale of the Kreyenhagen and similar material interbedded with the Vaqueros being impregnated with oil, so that at almost any point when broken they give off an odor of petroleum. The sandy strata of the Vaqueros likewise are locally impregnated where in contact with the shales. At a number of places where the beds are traversed by gullies the oil oozes out of them, and several wells have been drilled near by on the stength of these apparently promising indications. Among such seeps and wells the following may be mentioned: In the canyon of the Hamiltonian well, $1 \frac{1}{2}$ miles south of John Ashurst's place, north of the center of sec. 24, T. 17 S., R. 11 E., oil rises to the surface out of the overturned and broken strata near the contact between the sandstone of the Martinez (?) formation and the white sandstone of the Tejon. It doubtless has its source in the Kreyenhagen shale, which, owing to the local overturn, here underlies the relatively thin Tejon formation. The Hamiltonian 
well was drilled without success about 1,500 feet down into the stratigraphically underlying but owing to the overturn apparently overlying sandstone beds of the Martinez (?). Another seep occurs in the Kreyenhagen shale in the creek bed in the SE. $\frac{1}{4}$ sec. 16 of the same township. No wells have been drilled here. A third locality is in the canyon of the San Carlos well near the center of sec. 8 . There and in the next small canyon to the northwest oil seeps out of the same belt of shale and also appears abundantly, impregnating the sandstone and shale of the Vaqueros formation throughout their thickness. Still another seep appears at the summit of the Kreyenhagen shale in a canyon at the west side of the SE. $\frac{1}{4}$ sec. 6 .

The San Carlos well was drilled by hand to a depth of approximately 170 feet in the oily Kreyenhagen shale about 20 years ago and gave the region some notoriety. When bailed dry the well will fill with oil in the course of a few hours. In this way it was estimated originally that it might produce from 1 to 5 barrels of oil a day, but its capacity has never been tested and it is very doubtful if it would continue to fill as rapidly after the bailing process was continued for a short time. The oil is of light gravity and very good quality. The Riley well was drilled nearly half a mile north of the San Carlos well in the same section a number of years ago. It started near the top of the steeply dipping Vaqueros formation and went down for 1,200 to 1,500 feet without reaching the base of the formation and without finding oil. It did not afford a test of the area.

In the summer of 1912 a well called the Snelling well was started about 200 feet northeast of the old San Carlos well. It begins in heavy sandstone beds that are believed to be at the very base of the Miocene series. The monocline here dips approximately $50^{\circ} \mathrm{N}$. When visited at the end of September, 1912, the well had reached a depth of 800 feet through the underlying siliceous Kreyenhagen shale. At this depth the bailer was bringing up oil in quantities of a few gallons at a time. The oil is of a dark-green color and volatile, soon losing some of its lighter constituents on exposure. An analysis of the oil is given on page 131 .

About 2 miles northwest of the San Carlos well, in the southern part of sec. 31, T. 16 S., R. 11 E., a good seep occurs in sandy and gravelly beds interstratified with the clay of the Jacalitos and Etchegoin formations. This seep has already been described (p. 135). At this locality the Ashurst Oil Co. put down two or three wells, the deepest of which was between 600 and 900 feet deep and got a "showing" of oil and gas at about the horizon of the seep.

The only other well that was drilled to a depth of more than a few feet along this belt bordering the south side of The Vallecitos was the Calistoga well, drilled many years ago and abandoned. It is said to have gone to a depth of about 1,000 f'eet in the clay of the Jacalitos 
and Etchegoin formations on the terrace in sec. 18, T. 17 S., R. 12 E., about a mile southeast of John Ashurst's place, and to have obtained considerable gas. It is not believed to have reached the sands of the Vaqueros formation. The Fresno-San Benito well, which was drilled in Mancillas Canyon farther back in the hills, is mentioned on page 166 in connection with the discussion of the Moreno formation. The Moreno formation is separated from the Vaqueros formation by a great thickness of steeply inclined strata, and both for this reason and because it is believed to be absent as a result of faulting south of the western half of The Vallecitos it bears little relation to the question of oil occurrence along the south side of this valley and is not discussed here.

From the foregoing brief account of the wells along the south side of The Vallecitos it will be seen that none of them has afforded a real test of the area. Most of them were placed too near the outcrop of the oil-bearing beds for any large production to be reasonably expected and the better-located ones have not been drilled to a sufficient depth. The possibilities of the area are practically as much in doubt as if these wells had never been drilled. The conclusion reached from the geologic criteria is that the strata stand too steeply for the oil to be retained in very large quantities or for their deeper portions to be accessible to the drill at reasonable depths in more than a very small area. The beds undoubtedly contain petroleum, but the oil seems to have been disseminated and to have risen freely to the surface through a great thickness of strata rather than to have been concentrated in any particular porous stratum and held there. It is likely that wells started at some distance from the outcrop and striking the lower beds of the Vaqueros at a considerable depth would give a small production of oil, especially if a location were chosen where the monocline is not as steep as it is along most of its course. It is the opinion of the writers that although such wells will probably be able to produce oil commercially at some future date, the present cost of production and the present price of oil would not make it profitable. Moreover, it is possible that the porous beds are occupied by water at no very great depth and that most of the oil is near the surface.

\section{NORTH FLANK AND BAST END OP THE VALLECITOS SYNCLINE.}

GENERAL FEATURES.

In considering the north flank of the Vallecitos syncline attention must be given both to the Moreno formation and its associated or contained sands and to the higher oil-bearing zones of the Kreyenhagen and Vaqueros. Although seeps are not so numerous along this side of the valley as along the south side, indications do occur in both the lower and upper zones just mentioned. Along the western part of the north flank the structure is similar to that of the south flank, 
although the beds do not dip quite as steeply. The general dip of the monocline in the western part is between $40^{\circ}$ and $50^{\circ}$, and increases slightly from a point near the axis of the Ciervo anticline outward, so that the Miocene beds dip more steeply than the exposed Moreno and Panoche formations. Toward the east, however, the reverse is the case, and a decline in inclination of the Tertiary beds to angles of $20^{\circ}$ and $15^{\circ}$ or less brings about a broadening of the northern portion of the synclinal basin. Moreover, the Vaqueros formation laps unconformably over the older strata and dips at an angle of only a few degrees on the summit of the first ridge north of the valley. It would seem that formerly the Vaqueros extended back to the north a considerable distance at this low angle, over the truncated edges of the older strata. Just south of the summit of the ridge bordering the north side of The Vallecitos the Vaqueros formation slopes more steeply beneath the syncline, thus forming a monoclinal flexure on this portion of the north flank. The attitude of the hard sandstone beds of the Vaqueros (lower Miocene) is here represented fairly well by the surface slopes which these beds form. Around the east end of the basin the gentle inclination of the Tertiary beds continues, until they turn rather sharply into the steep southern flank. The surface indications of oil and developments that have taken place will here be described, beginning on the west.

WEST HALF OF NORTH FLANK OF THE VALLECITOS.

No certain evidences of oil have been discovered at the surface in the Kreyenhagen shale or Vaqueros formation along the western part of the northern flank of the Vallecitos syncline, but seeps occur in the Moreno formation and certain wells have obtained oil in small quantities from it. These wells have already been described in connection with the discussion of evidences of oil in the several formations.

These seeps appear in the upper beds of the Moreno in the canyon of the Union Oil Co.'s wells west of the stage road to Panoche, which follows down Griswold Canyon. The oil is of dark-brown color and is comparatively light and fluid. It emits a pleasant odor, and the seeps resemble in this respect and in general appearance those in the Oil City area in the Coalinga district. In fact, the formation here is the continuation of that at Oil City and the oil has doubtless had the same origin. The structure, however, is somewhat different, for in the Oil City locality the beds have a much lower dip and are folded into an anticline, whereas here they form a steep monocline. The character of the oil is indicated by the fact that at these seeps no large quantity of asphalt has been deposited.

The analysis of the oil quoted on page 124 shows it to have a specific gravity of 0.9150 to 0.9090 ( $23^{\circ}$ to $24^{\circ}$ Baumé) and to be inter-. mediate between a true paraffin and an asphalt oil. In this respect 
it is like the asphaltic paraffin oil of Oil City. The sample analyzed was not fresh, having stood in an open shallow well for some time; hence it is likely that the oil is of a lighter quality when it issues from the rocks. In a personal communication to the writers $\mathrm{Mr}$. W. W. Orcutt, of the Union Oil Co., stated that the oil obtained in this well (the "Rebecca," a dug well about 80 feet deep) was of 0.8433 ( $36^{\circ}$ Baumé) specific gravity, and that about 5 barrels a day of this oil was pumped out with a hand pump for several days in succession. Several wells were drilled in this vicinity to shallow depths many years ago, but the amount of oil obtained was small and the wells were abandoned, although a man was kept there to look after the property.

Below the horizon of the seeps the purple shale is impregnated with oil through a thickness of many hundred feet. The shale is about 1,000 feet thick and is oily practically throughout. It contains a number of large lenses of fine-grained gray and yellowish sandstone much like that typical of the concretionary members below and above, and these lenses might be expected to form local reservoirs for the oil at depths. The shale, as usual in rock of this type, is crushed and disturbed, but the general structure is that of a monocline dipping about $45^{\circ} \mathrm{S}$. The concretionary sandstone of the Martinez (?) immediately overlies the shale, and signs of its being slightly impregnated with oil at the very base were noted locally.

The conditions here are very much the same as in the area of the siliceous shale in the Kreyenhagen and Vaqueros formations on the south side of the valley, already described. It is probable that a small production, which might assume economic importance at some future time, in view of the good quality of the oil, would result from drilling operations in the shale of the Moreno formation here, but the prospect does not seem alluring under present conditions. It is not unlikely that oil might be found locally in sandstone lenses entirely sealed within the shale.

There is also the possibility of wells obtaining oil from the lower part of the sandstone that overlies the shale, and if serious drilling operations were to be commenced the logical place to start would seem to be at a point south of the outcrop of the Moreno, where the base of the sandstone and top of the shale would be reached at a depth of at least several hundred feet. It is believed, however, that the steep dip, the uniform monoclinal structure, and the dissemination of the oil through so great a thickness of beds preclude the hope that the Moreno and the Martinez (?) formations will be found commercially productive in the near future. The area to which these conclusions apply lies in the N. $\frac{1}{2}$ sec. 19 , the S. $\frac{1}{2}$ sec. 18 , T. 16 S., R. 11 E., the NE. $\frac{1}{4}$ sec. 24 , and the S. $\frac{1}{2}$ sec. 13 , T. 16 S., R. 10 E. Farther east the purple shale of the Moreno formation is reduced to a 
thin zone, and in that direction the outcrop of the shale itself does not afford promising territory for the production of even a small amount of oil. What possibility there may be in this area farther east for oil gathering from below into the concretionary sandstone overlying the shale can not be forecast, but it is unlikely that any important quantity gathers there. In a westerly direction the area above outlined extends to Griswold Canyon, the western limit of the region studied. The same steep monocline of the Cretaceous and later beds continues westward from Griswold Canyon along the north side of the valley of Pimental Creek.

As the structure of the Vaqueros formation is very similar to those just described, and as there is no good surface sign of petroleum in it or in the Kreyenhagen shale, the chances for oil in this upper zone appear even slighter than those for oil in the lower zone, along the western half of the north flank of the syncline. At one point about a mile east of Griswold Canyon an oily appearance was observed in the Vaqueros formation and a faint petroleum odor obtained. This was just enough to indicate that the slightly petroliferous character of this formation persists this far west. One well-that of the Sussex Oil Co.--was drilled in this region between 1910 and 1912. It is situated near the center of sec. 30, T. 16 S., R. $11 \mathrm{E}$. It started in the steeply dipping clay and gravel beds of the Jacalitos and Etchegoin formations and is reported to have been drilled a little deeper than 1,800 feet and to have obtained signs of oil and gas before operations were stopped. At this depth it had probably reached the middle portion of the Vaqueros, but it could not have gone as far as the base of that formation, which should have been reached in order to make an adequate test.

It should be noted, as having a possible bearing on the question under discussion, that an intrusion of basalt occurs at one place on the north side of The Valkecitos. It penetrates the formations at least as far up as the summit of the Vaqueros sandstone and shale. The basalt outcrops about 2 miles north of the divide between the two arms of The Vallecitos, as a small intrusion parallel to the bedding near the contact of the Vaqueros with the overlying Jacalitos and Etchegoin formations. It is the only known evidence of igneous activity later than Jurassic or early Cretaceous in a wide stretch of country south of Panoche Creek and east of Griswold Canyon. Owing to its local nature it is very doubtful if it has seriously affected the oil-bearing character of the beds, except in its immediate vicinity.

EAST HALF OF NORTH FLANK OF THE VALLECITOS.

The problem to be considered in the area along the eastern portion of the north flank and around the east end of the fold differs from that presented by the more westerly area, owing to the lower dip in 
the Tertiary beds and the presence of signs of oil in them. The Moreno and the formation immediately overlying do not assume much importance here, owing to the lack of seeps, as well as to the continuation of the unfavorable structure of the area farther west. Very likely these beds contain a little oil disseminated through them, but unless some as yet unsuspected evidence should be brought to light it seems foolish to spend money drilling to or into the Moreno formation here.

Structural conditions, although not highly favorable, suggest that oil may have collected in the Vaqueros, in the northeastern part of The Vallecitos. This formation, moreover, shows undoubted indications of oil. The area has certain points of resemblance to the Westside field, which make it worthy of careful consideration. The Vaqueros formation here is the same formation as that containing the main oil sands of the Coalinga district and consists of similar porous sands. It overlies unconformably the siliceous Kreyenhagen shale, the supposed original source of the oil, just as it does at Coalinga. It lies in a gently dipping monocline on the flank of a syncline, as in the Westside field. It shows at least in one place at the surface signs of petroleum only a little less pronounced than those in the Coalinga field, and it is overlain here, as there, by relatively impervious clay and shale. The main difference from the Westside field is not one of local attitude or character of the beds but involves a consideration of the broader structural relations, which are perhaps of greater importance than the similarities above mentioned and will be discussed in the final paragraph of this section (p. 177), where conclusions regarding the possibility of this area and of The Vallecitos as a whole will be expressed.

The outcrop of oily sand above referred to occurs on Silver Creek in the basal beds of the Miocene, where they rest on the truncated edges of the slightly more steeply dipping Kreyenhagen shale. The locality is on the northeast edge of The Vallecitos, in the western part of the SW. $\frac{1}{4}$ sec. 5, T. 17 S., R. 12 E., just east of the New Bedford well. The same beds show slight evidences of being oily at other points along the outcrops to the northwest, but not sufficiently so to prove the existence of a considerable petroleum reservoir.

The Vaqueros contains beds of hard sandstone that may easily be traced along their outcrops, because they form the first high ridge parallel with The Vallecitos on its north side. The formation is 700 or 800 feet thick and consists of a lower zone about 100 feet thick of variable sandy, gravelly, and shaly beds, an overlying zone about 80 feet thick of siliceous diatomaceous shale, and an upper portion over 500 feet thick composed chiefly of sandy strata with some interbedded shale and containing two prominent beds of hard sandstone in its central part, each about 100 feet thick. (See the tabulated section $81281^{\circ}-$ Bull. $-603-15-12$ 
on p. 86.) The lower sandy zone has the thickness and lithologic qualities that would make it an excellent reservoir were oil present in large quantity. Furthermore, the overlying flinty shale ought to serve as an impervious cap to prevent the oil from rising into higher beds. The escape of the oil along the bedding planes would be hindered by the lowness of the dip and by the tendency of the oil to seal itself in by the deposition of solid résidue near the surface. The monoclinal dip of the Vaqueros formation within about a mile west of Silver Creek is slightly variable, but on the average it is only from $3^{\circ}$ to $8^{\circ}$. toward the southwest. Locally there is a tendency toward flattening, affording small wrinkles that might be a factor in helping to hold oil. The dip of the monocline is sufficiently low to make the basal portion of the Miocene beds accessible within a reasonable depth, even as far out as the axis of the Vallecitos syncline.

About 2 miles west of Silver Creek there is an abrupt steepening of dips in the Miocene formations along the edge of the valley to $20^{\circ}$, $30^{\circ}$, and finally $45^{\circ}$ or more. For several miles beyond the beds preserve a low dip on the very summit of the ridge, but they fold over abruptly into the steep dips on the south side. The steepness of these dips, combined with the lack of evidence of any appreciable quantity of oil in the beds, would seem to leave little basis for expecting them to be commercially productive west of the very small area of low dips at the east end of the north flank, already described.

Around the east end of The Vallecitos the Tertiary beds are brought to the surface from beneath the valley by the rising end of the syncline and occupy crescent-shaped belts that curve around the end of the valley. The dip of the beds is everywhere toward the valley and varies between $5^{\circ}$ and $30^{\circ}$. The structure is not of the most favorable type for the accumulation of oil, and yet it is such that a certain amount of oil would be expected to accumulate if any existed in the beds. The shale of the Vaqueros lies unconformably upon the Kreyenhagen shale, as in the Coalinga field, and if oil were present in the shale it should rise and collect in the sandy strata overlying its truncated edges, making itself apparent at the outcrop. No seeps or other surface signs of oil were discovered east of San Carlos and Silver creeks, but this does not prove that they do not exist, for the beds are locally masked by terrace deposits.

The following wells have been drilled in the area under discussion: The New Bedford Oil Co.'s well, in the NE. $\frac{1}{4}$ SE. $\frac{1}{4}$ sec. 6, T. 17 S., R. 12 E.; the Vallecitos Development Co.'s well, in the NE. $\frac{1}{4}$ sec. 12, T. 17 S., R. 11 E.; and the Range 16 Oil Co.'s well, in the SE. $\frac{1}{4}$ sec. 3, T. 17 S., R. 11 E. The New Bedford well is situated just west of Silver Creek, near the outcrop of the oil sand above mentioned. It starts in the basal portion of the Vaqueros and passes through the oil sand that outcrops on Silver Creek at a depth of only 
about 100 feet, but obviously it is too near the outcrop of the oil sand of the Vaqueros to obtain any production from it. Practically the whole depth drilled, which is now reported as more than 3,000 feet, has been below the oil zone of the Vaqueros, the zone in which oil should be sought for in this district. At about 1,600 foet this well passed through a 6 -foot bed of coal in white sand, evidently the coalbearing white sandstone of the Tejon. Oil is said to have been struck at a depth of about 1,700 feet, but it has not been possible to substantiate the report. At a depth of 3,000 feet the well should be in the midst of the Martinez (?) formation, which is here very thick. It would probably require a depth of at least 1,000 feet more to reach the possibly oil-bearing beds at the top of the Moreno formation.

The well of the Vallecitos Development Co. was started in 1910 on the terrace a mile north of John Ashurst's place. It started in the lower beds of the Jacalitos and Etchegoin formations, where the synclinal flank has a low dip, and was excellently placed to test the possibilities of the zone at the base of the Vaqueros. Definite information regarding the results obtained are not available, but the well is reported to have gone to a depth of over 2,000 feet, or entirely through the Vaqueros, and to have found some oil at the base of this formation. The tools brought up from the bottom were said to be covered with oil. From the fact that the well was practically abandoned in 1911 the writers infer that it did not prove a success.

The Range 16 Oil Co.'s well is situated over 2 miles farther northwest and starts in the midst of the Jacalitos and Etchegoin formations, on a part of the synclinal flank where the dip is steeper than farther east. It was drilled in 1910-11 to a depth of 2,300 feet, without obtaining oil in any important quantity. At this depth the well must have nearly if not quite reached the base of the Miocene series.

CONCLUSIONS REGARDING THE VALLECITOS DISTRICT.

Considering only the evidence obtainable from a surface study, the area described in the paragraphs just preceding-that is, the east end of the north flank and the curving east end of the synclineseems a fairly promising place to search for oil and the most promising portion of the Vallecitos district. The amount of oil that comes to the surface at various points in The Vallecitos, and the resemblance of the structure in the east end of the valley to that of the Westside field make it not unreasonable to suppose that oil may have collected here in fairly good quantity. This conclusion was expressed in the preliminary. report on the Cantua-Panoche region. ${ }^{1}$ That report was prepared before any wells had been started to test the sands in the Vaqueros formation at the east end of The Vallecitos, and it sug-

${ }^{1}$ Anderson, Robert, U. S. Geol. Survey Bull. 431, pp. 76-77, 1910. 
gested a small area at that end of the valley as offering a reasonable location for the drilling of a test well. Such a test has subsequently been made by the well of the Vallecitos Development Co. before mentioned, and although it has not been possible to ascertain definitely the results obtained in this well, numerous indications point to its having been a failure. 'The writers believe it likely that below the surface the Vaqueros formation does not contain as much oil as one might be led to believe by a comparison of the surface evidences of oil in this region with similar evidences in regions that have been found highly productive. As stated in the preliminary report, the drill alone can determine with certainty whether oil exists in paying quantities in the beds which at the surface show traces of oil. The opinion at present held by the writers is based on the apparently unfavorable evidence afforded on this point by the well previously referred to, and on a more general consideration of the conditions governing oil accumulation along the western border of the San Joaquin Valley. These conditions have been discussed in considerable detail in the section dealing with the factors influencing accumulation of oil (pp. 116-121). As there stated, the fact that The Vallecitos is a local basin entirely separate structurally from the San Joaquin Valley or from any other outside territory that might be tributary to its oil and water supply points to the probability that no very important petroleum accumulations are to be looked for in this valley. The writers would not recommend the expenditure of any money in further attempts to obtain paying quantities of petroleum anywhere in the Vallecitos district, until the value of oil has increased or the expense of operating decreased to such a point that risks could be taken for the sake of obtaining occasional very small producing wells.

\section{CREST AND FLANKS OF THE CIERVO ANTICLINE.}

The Ciervo anticline is an oblique offshoot of the main structure of the Diablo Range, similar in type to the Coalinga anticline. It is probable that in the past history of the region, in late Tertiary or early Quaternary time, the summit of the anticline was covered throughout areas many square miles in extent by the Tertiary formations and that oil accumulated in large quantities along it. During the course of time, however, the oil-bearing formations, together with their stores of oil, have been worn away from the major portion of the anticline, leaving the underlying unproductive sandstone of the Panoche formation (Upper Cretaceous) exposed in a wide belt on either side of the axis. The only place where beds as young as the lower oil-bearing zone of this region remain over the axis of the fold is at its east end, where it plunges steeply and merges with the monocline of the foothills. At this place it is covered by shale of the 
Moreno formation, the overlying concretionary sandstone and clay shale of the Martinez (?) formation, and the succeeding Tejon formation. The area embracing this end of the anticline is the one which will be discussed here.

The structure of this area is similar to that of the plunging end of the Coalinga anticline, which has proved so productive, and the chance for the presence of oil here deserves careful consideration. The most important differences between this area and that on the nose of the Coalinga anticline are as follows: The Ciervo anticline is not so extensive a fold as that at Coalinga. It stops short without reaching the San Joaquin Valley and plunges abruptly without affecting strongly the Tertiary beds of the foothills, whereas the Coalinga fold continues on for many miles into the valley with a perfect cover of Tertiary formations. On the Ciervo fold only one of the shale formations of organic origin (the Moreno, Upper Cretaceous) is present and the evidences of oil in this formation are not pronounced; on the Coalinga anticline the two oil-bearing shale formations are present, and both give at their outcrops unmistakable evidence of their petroliferous character. Moreover, on the Ciervo fold the Moreno formation outcrops just at the point where the fold plunges steeply to its termination, instead of continuing along the axis at a relatively low and constant dip beneath the later formations. These differences are all unfavorable to the Ciervo area when its possibilities of yielding oil are compared with those of the Coalinga fold. They lead to the conclusion that the Ciervo area, if productive at all, will be very much less so than the Coalinga anticline. Owing to the limitation as regards possible oil-bearing formations on this fold, the proper comparison to be made is with the Oil City field and with the sands in the Martinez (?) and Tejon formations in the Coalinga district. The result of this comparison is likewise unfavorable to the Ciervo field, and yet there is enough similarity to suggest the possible existence of a commercial quantity of oil here.

The purple shale of the Moreno formation is exposed in an area of several square miles near the axis of the Ciervo anticline in secs. $14,15,21,22$, and 23 , T. 16 S., R. 12 E., and passes beneath later beds along the summit of the fold in the SW. $\frac{1}{4}$ sec. 24 , the NW. $\frac{1}{4}$ sec. 25 , and the N. $\frac{1}{2}$ sec. 26 of the same township. The area near the summit of the fold in which the shale of the Moreno would be within reach of a drill or at a depth of not more than 3,000 feet below the surface is approximately outlined by a red line on the geologic map (Pl. I). Several doubtful factors, such as abrupt variation in thickness of the different formations and uncertainty as to the attitude of the beds, make the drawing of such a line difficult, and it is shown merely for the purpose of giving a rough indication of the more important part of the area here under discussion. 
If any appreciable quantity of oil is present in the Moreno formation the conditions of structure in this area make it probable that productive wells could be obtained by drilling down to included lenses of sand, or to the sandstone beds that overlie the shale.

Mention has previously been made (in the section dealing with oil indications in the several formations) of the oily sands discovered at certain places in the Moreno formation near the axis of the Ciervo anticline. In addition the shale gives the appearance of having been thoroughly impregnated with petroleum. It is characterized by the blackish-brown discoloration and strong sulphurous odor that seem to result from the presence of oil in shale of this type in many places. The oil sands easily escape notice owing to the weathered nature of the exposures, but the appearance of fresh specimens of the rock leads to the belief that a large part of the formation has previously been and may still be soaked with oil and that a considerable amount of free oil might be found in the beds at greater depth, away from the surface zone of weathering and evaporation. The light oil found in the purple shale at Oil City and at the Union wells, north of the west end of The Vallecitos, which appears to be characteristic of this horizon, is of a type that would not be expected to leave at the surface as marked evidences of its presence as the asphalt oil in the Miocene formations of the Coalinga district and other parts of California.

If the formation contains as large an amount of oil as is believed, the question remains whether the oil is too widely disseminated through many hundred feet of beds to be obtainable in commerical quantity, or whether some of it has accumulated in reservoirs that may be profitably tapped. There can be no doubt that a large amount has been lost by dissemination through the beds and escape at the surface, as is attested by the prevalence of the oil discoloration throughout the formation. But it is an important fact that thick lenticular beds of porous, fine-grained sand which ought to be good reservoirs are included in the shale, and it is highly probable that much oil has been absorbed by these lenses and retained in them. The lenses are not confined to any particular part of the shale but occur in its upper as well as its lower portion and would be found somewhere within the shale in any section that might be made of it. Some of the lenses attain a thickness of 100 feet or more. The body of oil-bearing beds of which the purplish shale is the chief constituent is likewise overlain by sandy strata in which, it might be expected, oil would accumulate. Wells drilled through the later beds at a considerable distance from the outcrop of the purple shale would probably reach the shale and its included sands at a depth at which the petroleum contents would be sealed in and preserved intact. A good situation for a test well is about 2 miles northwest of Ciervo Mountain. 
The dip of the beds in the Ciervo Mountain region is low and the structure is undulating, and it is not impossible that some of the minor folds might aid in the concentration and confinement of a local body of oil. In this connection it is worthy of note that a number of small faults occur in the Tertiary formations in this region which have not brought to light any oil through seepage; but in the opinion of the writers this fact does not carry great weight as against the favorable conditions mentioned. The conclusion is that the area on and adjacent to the Ciervo anticline offers possibilities that should be tested. It is believed that a well drilled near the summit of the anticline, as suggested, would have a chance of obtaining a light oil in paying quantity, but the risk of failure would be great and the likelihood would be of a small production, if any, being obtained. This much, at least, may be said-that the conditions are much more favorable than those in many places where "wild-cat" wells are being drilled in California outside of the developed fields.

As regards the belts of shale of the Moreno formation extending from the axis of the Ciervo anticline westward on the south flank of the fold to Silver Creek and northwestward on the north flank nearly to the mouth of Little Panoche Creek, the conclusion is that these areas do not show great promise. This conclusion is based on the fact that these belts form monoclines similar to those mentioned in the discussion of the outer and inner foothill areas north of the Coalinga district. The shale looks as if it had been oily, and it probably does contain some oil below the surface. This probability, together with the presence in the shale of lenses of sand like those on the anticline, makes it possible that oily zones would be found if the beds were tapped at a considerable depth, but there is nothing to warrant drilling.

\section{REGION AROUND THE MOUTH OF PANOCHE CREEK.}

A small area around the mouth of Panoche Creek is worthy of special consideration because within it the strata present a pronounced diminution in dip, and because the shales of the Moreno and Kreyenhagen formations are not separated by so great a thickness of beds as they are in the Ciervo Hills region and both would be accessible in any one well in an area extending some distance out into San Joaquin Valley. The structure in this vicinity differs from that along the valley border to the south in that the older Tertiary formations outcrop at the very edge of the hills, the Vaqueros and later formations being for the most part hidden by the alluvial cover of the plain. It also differs in that the older Tertiary strata dip in general less than $20^{\circ}$ in the outer hills and pass beneath the valley at a still lower inclination. The decrease in dip is due to the action of the same forces 
that formed the imperfect Panoche Hills dome, and the area is the southernmost one in which these forces were active. There is no feature of the structure in the area under discussion, however, that even remotely approaches a dome or fold. It is simply a monocline with moderate dip. The relatively low dip and the presence at reasonable depth of both of the shale formations that are regarded elsewhere along the range as the source of the petroleum suggest that conditions slightly more favorable for the gathering of petroleum might have been afforded here than along the steeper portion of the monocline between this place and the north edge of the Coalinga district. The indications of oil, however, are very slight. Locally there occur lenses of sandstone in the shale of the Moreno formation that look as if they had been oil stained, and it is likely that the formation contains traces of petroleum. No indications of oil occur in the outcrops of the Martinez (?) formation above it, nor in the Kreyenhagen shale. The Vaqueros formation does not outcrop; so there is no clue as to what it may contain, but such sandy and gravelly beds as overlie the Kreyenhagen shale show no traces of oil or asphalt. It would be expected that evidences of oil would appear at the surface if any important quantity of petroleum occupied the beds at depth.

One well in the area under discussion has been drilled to a considerable depth. This is the well of the John Kern Oil Co., which started in the Martinez (?) on Panoche Creek, about $1 \frac{1}{4}$ miles above the mouth of the creek, and went to a depth of about 4,000 feet. It must have passed through a large part of the Moreno formation, and the fact that it did not obtain any oil goes far toward indicating that nothing is to be expected from the lower shale of organic origin and the associated beds in this part of the field.

The conclusion regarding the possibilities of the area near the mouth of Panoche Creek is unfavorable. Although the strata are somewhat less steeply tilted, the structure is similar to that along the monocline to the south, and in the absence of any good surface signs of oil or of any outlying fold such as is believed essential to the accumulation of oil along the west border of the San Joaquin Valley the chance of obtaining oil seems poor.

\section{REGION FROM PANOCHE CREEK TO CORRAL HOLLOW}

GENERAL FEATURES.

The eastern flank of the Diablo Range from Panoche Creek northward presents very little diversity of structure. With the exception of the folds and faults associated with the Panoche Hills and Panoche Valley, of a local anticline in the foothills near Salado Creek, and of some minor complexities in the area just south of Corral Hollow, the structure throughout the territory is that of a continuous monocline 
of Franciscan, Chico, and Tertiary rocks dipping toward the San Joaquin Valley. This is the same as the structure discussed above in connection with the foothills north of the Coalinga district. In addition to having this unfavorable structure the unlikely aspect of this area as regards any possibilities of yielding oil is emphasized by its distance from territory in which petroleum has been found in commercial quantity and especially by the entire lack of any definite indications of the presence or even former presence of oil. The Moreno formation, which has so intimate a relation to the occurrence of oil in the Eastside field and the Vallecitos district, is traceable practically the whole way along the outer border of the hills to the north. The Kreyenhagen shale is also present in a part of the region, but neither of these formations gives evidence in this area of containing petroleum. It seems probable, therefore, that oil is not present, for if it did occur in them or in their associated beds in any appreciable amount it would be strange indeed if oil did not show itself at the outcrop at some point in this extensive region. Between Salado and Garzas creeks, north of Pacheco Pass, the regular monoclinal structure is somewhat modified and the possibility of oil having collected is not so remote as in other parts of the region. This area and the Panoche Hills, which offer some peculiarities of structure, will be discussed somewhat more in detail.

\section{PANOCHE HILIS AND PANOCHE VALLEY.}

The Panoche Hills have an imperfect domelike structure bearing some resemblance to that of the spur folds already described as the Coalinga and Ciervo anticlines, and the Panoche Valley. is roughly analogous to the synclinal basins of Pleasant Valley and The Vallecitos. The structure of the Panoche Hills and Panoche Valley might, therefore, be regarded as favorable for the occurrence of oil were it not for the fact that the oil-bearing shales of other parts of this region are either absent here or so small in extent as to be of practically no importance. As would be expected, in the absence of these formations no signs of oil occur in the area. The main mass of the Panoche Hills is formed of sandstone and clay shale of the Panoche formation. The Moreno formation probably once arched over these hills, but it has been eroded away except in the general monocline low down on the northeast flank of the hills. The shale of the Moreno outcrops in a small area on the south side of Panoche Valley and may underlie a good many square miles within the valley, but its area is too small and too much isolated to warrant the belief that any important amount of oil has collected in it. Moreover, the structure in that part of the valley is not favorable for the collection of oil. The Kreyenhagen shale is absent in this area, so far as known, except in the monocline at the southeastern base of the Panoche Hills. 


\section{AREA ABOUT SALADO CREEK.}

About midway between Puerto and Salado creeks the strike of the strata in the outer foothills changes rather abruptly from N. $40^{\circ} \mathrm{W}$. to almost due north. This trend is maintained for a distance of about 15 miles to a point near Garzas Creek, where it changes as abruptly as before, returning to the original northwest orientation. North of Puerto Creek and south of Garzas Creek the easternmost exposed beds of the monocline dip steeply, but in the intermediate area, where the strike of the beds is north, Tertiary strata have a low dip along the border of the valley. As has been pointed out in the discussion of the structure, this bending of the strata may be compared to the oblique folding farther south, but here the forces have been less intense and actual folding in the foothills has taken place only in the north end near Salado Creek. Here the Moreno and Tejon formations have been folded into a small anticline which has been traced at the surface for about a mile. The effect of this fold is shown at the surface for a short distance southeastward beyond the end of the axis as mapped, by the swinging about of the outcrop of the San Pablo formation south of Salado Creek. It is possible that the fold continues even farther south and that it affects the Tertiary formations underlying the terrace deposits south of Crow Creek.

The general structure of this area is similar to that about the mouth of Panoche Creek and as in that area is somewhat more favorable for the collection of oil than in adjacent areas. It differs, however, from that of the area to the south in two particulars. First, although both the Kreyenhagen shale and the shale of the Moreno formation are present, they are separated by over 3,000 feet of strata, and a well drilled to test the sands overlying the upper shale would not be well located to test those overlying the lower shale. Second, besides the flattening of the dips of the monocline, a reverse dip has been developed locally and a small fold has been produced near Salado Creek.

About 2 miles north of Salado Creek, where this fold is well marked, the Kreyenhagen shale has been removed by erosion and only the older shale of the Moreno formation is affected by the fold. No evidence of petroleum was discovered at the surface along the axis of the fold, but the possibility can not be denied that oil may have collected in the lower part of the sandstone member of the Moreno. The axis of the fold is occupied here by the upper sandstone member of the Moreno, which has a thickness of about 1,000 feet and through which it would be necessary to drill to test the lower sands. A well was drilled, it is said to a depth of about 1,100 feet, by the Mount Oso Oil Co., in the SW. $\frac{1}{4}$ sec. 3 , T. 6 S., R. 7 E. This well could hardly have been drilled in a more disadvantageous location. It starts in the Tejon formation, which overlies the upper member of 
the Moreno formation where it dips about $45^{\circ}$ on the monocline forming the main range. This well evidently did not reach the base of the upper sandstone member and did not obtain oil. Had it been drilled about half a mile farther north along the axis of the anticline it would have given the area a fair test.

The possible value of the edge of the San Joaquin Valley between Salado and Garzas creeks as oil-producing territory is mainly dependent on the Kreyenhagen shale, as the shale member of the Moreno is here covered by over 4,000 feet of strata. The Kreyenhagen shale in this area is apparently identical in lithologic character with that at Coalinga, and there is as much reason to believe that it might have produced oil here as in the region to the south. In the foothills near Crow Creek the Kreyenhagen shale has a maximum exposed thickness of about 750 feet, but it is probably thicker beneath the San Joaquin Valley owing to the unconformable overlapping on it westward of the late Tertiary formation. Along the edge of the valley the Tertiary rocks in a belt over 2 miles in width are tilted less than $20^{\circ}$ and where last exposed along the edge of the hills dip eastward at an angle of $4^{\circ}$ to $5^{\circ}$. It is reasonable to suppose that the dip decreases farther east under the San Joaquin Valley. Should oil have been formed in the Kreyenhagen shale here and collected in the overlying sandy beds, as in the south, its migration up the bedding planes would be much retarded by the low dip, and some of it might still be retained beneath the San Joaquin Valley. The possibility of the small fold near Salado Creek continuing southeastward beneath the valley has already been mentioned. Should it affect the strata there, even though it were represented only by a local flattening of the dip and the production of a structural bench without the development of reverse dips, the possibility of oil having been retained would be much greater than it would if the monocline flattened gradually eastward. The area along the foothills where the conditions are most favorable for the collection of oil and where it seems probable that oil will be found if it occurs anywhere in this region is near the mouth of Crow Creek, about 3 miles southwest of Crows Landing.

\section{CONCLUSION.}

In conclusion, the question whether or not there is a chance for finding oil in the region from Panoche Creek to Corral Hollow may be summed up by referring to the discussion of the outer and inner foothill areas north of Coalinga (pp. 162-167), which cover the monocline extending northwestward from the Coalinga district. Except in the area along the foothills between Garzas and Puerto creeks the same general reasons apply to the Panoche Creek-Corral Hollow province as those used in arriving at a conclusion unfavorable to the other foothill areas, with the exception that practically no wells have been drilled in this more northerly region. 
Along the axis of the small anticline near Salado Creek there is a possible chance that oil may have accumulated from the underlying shale of the Moreno formation. It is likewise possible that along the border of the San Joaquin Valley from Garzas Creek to Salado Creek oil may have collected in the slightly dipping sand overlying the Kreyenhagen shale. The entire lack of indications of petroleum at the surface, however, makes the value of these localities doubtful. Except in these localities the geologic features of the area are believed by the writers to afford sufficient basis for the conclusions that it is without promise for oil and that the expenditure of money in drilling here would in all probability prove a waste.

TESLA AREA.

PRINCIPAL FEATURES.

North of Hospital Creek the monocline, which is almost unbroken northward from Panoche Creek, ends, the structure becomes more complex, and faults and folds are numerous. Like the folds farther south many of the flexures in the foothills here have a trend oblique to the course of the range, and some strike directly across it. Some of these folds offer favorable structural conditions for the collection of petroleum, should it be contained in sufficient amount in the rocks. In this area the Kreyenhagen shale, the upper of the two shale formations about which the oil-producing zones to the south group themselves, is lacking. (See Pl. XIV.). The lower shale, that of the Moreno formation, is present, however, although in somewhat different form than in the south, and it is probable that this formation is the one in which the petroleum occurring here originated. Those parts of the area, therefore, where the structure is favorable and where the shale of the Moreno does not lie too deeply buried should be critically examined as possible oil territory.

The Moreno formation outcrops in two areas along the outer foothills between Hospital and Corral Hollow creeks and in a narrow east-west belt extending from a point about 2 miles west of Tesla nearly to Carnegie. North of these areas the Moreno either does not outcrop or else its character has changed radically.

The belt of outcrop of the Moreno formation that trends through the outer foothills between Hospital and Corral Hollow creeks is formed largely of purplish shale, apparently containing a considerable amount of material of organic origin which, it is believed, might have formed petroleum. The structure, however, is not favorable for the collection of petroleum, although it is barely possible that small amounts might enter and be retained in the slightly dipping Tejon and younger formations which overlie the Moreno formation along the broken syncline to the west. The Moreno probably underlies the San Pablo formation east of the fault line that extends south- 


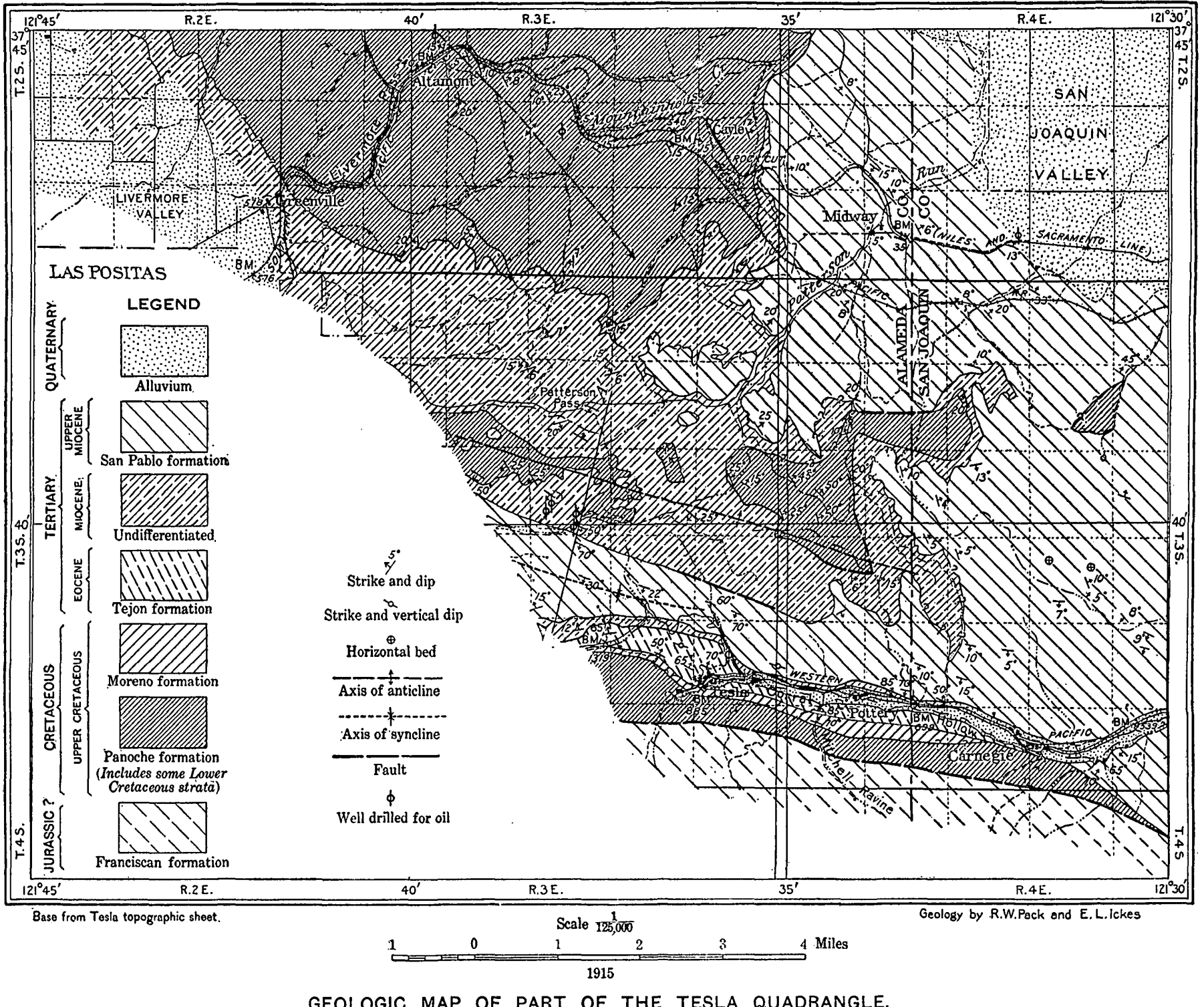


eastward from the mouth of Corral Hollow Creek, entering into the monocline that forms the outer hills. The structure east of this fault is similar to that along the edge of the valley south of Hospital Creek and is not specially favorable for the collection of oil.

No evidence of petroleum was discovered along the outcrop of the Moreno formation which passes through Tesla. These beds form part of the northward-dipping monocline and dip at angles varying from $50^{\circ}$ to $90^{\circ}$. They probably continue northward, however, under cover of the Tertiary beds that occupy the syncline about a mile north of Tesla, and are believed to be of importance with relation to the occurrence of petroleum at the Hamilton ranch.

HAMILTON RANCH.

On the old Hamilton ranch, in sec. 15, T. 3 S., R. 3 E., there are outcrops of oil sand and seeps of light-gravity oil. These indications

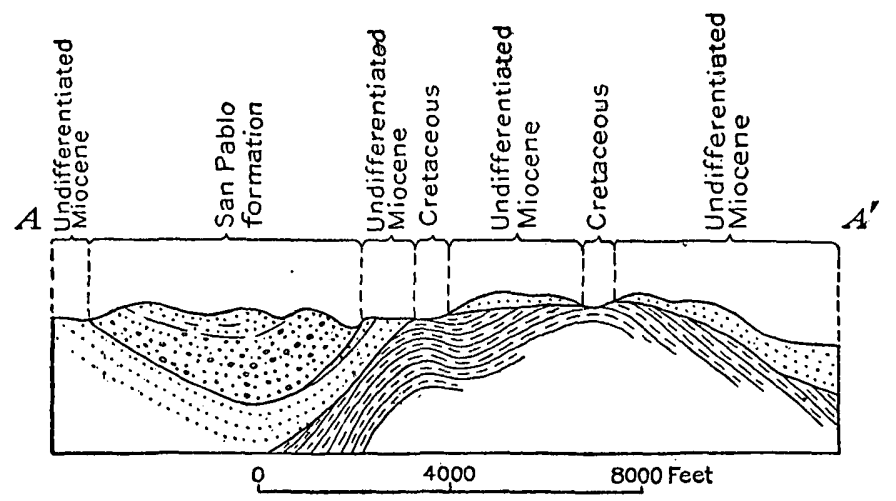

Figure 5.-Hypothetical section through the Hamilton ranch, near 'Tesla, along line $A-A^{\prime}$ ' on Plate XIV.

of petroleum have been described in more detail in another portion of this report (pp. 136-137). It is sufficient here to say that the oil is contained at the surface in the loosely consolidated sand and gravel that constitute the lower beds of the undifferentiated Miocene. These beds rest with marked unconformity upon the more steeply tilted shaly beds of the Chico group (Upper Cretaceous). All the seeps lie on the south flank of the broad and irregular anticline that trends in a general easterly direction through the N. $\frac{1}{2}$ sec. 15 , and all occur close to the line where the attitude of the beds changes abruptly, the dips, though continuously toward the south, changing from a low to a high angle. The character of the fold is shown diagrammatically in figure 5. A small exposure of the Cretaceous shale occurs in the gulch northeast of the Hamilton ranch house, a few yards above the seep noted above. These beds dip northward, a fact which has led many to believe that the dip of all the strata is in that direotion, and it is commonly thought by the oil men operating 
there that the oil sands encountered in the wells that have been drilled close to the ranch house lie under a constantly increasing cover toward the north. This is an erroneous idea, for the attitude of the beds exposed in the gulch is very local and the prevailing dip of the strata is in the opposite direction.

No trace of oil was noted by the writers in the surface outcrops of the Chico group in this part of the region, nor, so far as is known, have seeps been reported in them. Oil evidently does occur in this group, however, as it has been found in the lower part of wells that have been drilled through the undifferentiated Miocene into the underlying Chico.

The source of the petroleum that exudes from the undifferentiated Miocene is a matter of conjecture. The structural conditions indicate that its mode of occurrence is analogous to that of the oil in the Vaqueros formation (lower Miocene) of the Coalinga and Vallecitos districts and in the Santa Margarita (?) (middle Miocene) and Jacalitos (upper Miocene) formations of the Westside field, namely, that it has gathered in porous strata unconformably overlying strata from which it has migrated. There is no reason for believing the oil to be indigenous in the undifferentiated Miocene. If, then, these beds are simply a reservoir into which the oil has migrated, the question arises whether the oil has come from the Chico (Upper Cretaceous) strata that immediately underlie the oil sand at its outcrop, or whether it comes from younger Cretaceous or Tertiary strata that underlie the oil sand at depths but do not reach the surface here. It is not known to just what part of the Chico group of the Cretaceous the beds immediately underlying the oil-bearing undifferentiated Miocene on the Hamilton ranch belong. They may be the upper part of the Panoche or the lower part of the Moreno formation. There is no question, however, that they contain oil, as it is obtained in small amount by the wells that have been drilled into them, and it is possible that they supply all the oil that finds its way into the overlying more porous sandstone. It is believed highly probable, however, that much of the oil has migrated from Cretaceous beds which are younger than those exposed near the seep, and which underlie the oil-bearing Miocene beds at depth. This conclusion would be in accord with what is known of the Moreno formation farther south, for there the uppermost beds of that formation are more largely of organic origin and are more petroliferous than the beds in the lower part. Where the shale of the Moreno formation is exposed along the road from Livermore to Tesila, about $1 \frac{1}{2}$ miles south of the Hamilton ranch, it dips steeply to the north beneath the Tejon on the south flank of a syncline. Near the seeps the Chico strata dips southward on the north flank of this syncline, and the undifferentiated Miocene has in the intervening space overlapped upon lower and lower beds, so 
that it here rests upon beds that are older than the uppermost ones comprised in the Moreno formation, leaving the Tejon and the uppermost part of the Moreno buried. To judge from the structure it is likely that these uppermost beds of the Moreno formation are present beneath a cover of only a few hundred feet of Tertiary strata within half a mile south of the seeps.

Another possibility is that the oil originated in the carbonaceous shale of the Tejon that is associated with the coal-bearing beds at Tesla. This is not believed probable, however, for although coalis found in these beds at several places along the Diablo Range oil is nowhere known to occur with it in appreciable quantity. It is also worthy of note in this connection that the beds mapped as the Moreno formation northwest of Tesla contain a considerable amount of carbonaceous matter, evidently derived from terrestrial vegetation. It is possible that this organic matter, as well as the remains of minute marine life the beds contain, may have been the source of the oil.

The following wells have been drilled near the seeps on sec.15. All were idle or abandoned in December, 1912.

The 15-3 Oil Co.'s well, located near the base of the gulch a few hundred feet upstream from the old ranch house. Drilled over 12 years ago to a depth of about 1,200 feet.

Independence Oil Co.'s well, located a few hundred feet up the gulch from the 15-3 Oil Co.'s well. Drilled in 1911-12 to a depth of 1,700 feet.

Alisal Oil Co.'s well, located about 2,000 feet west of the ranch house in the western of the two gulches showing seepages. Drilled in 1909-10 to a depth of 979 feet.

W. M. \& S. Co.'s two wells, located a few hundred feet northeast of the Alisal well. Drilled during 1910-11 and 1912 to depths of about 600 feet.

Doane (?) well, drilled about 25 years ago a few hundred feet southwest of the Alisal well. No definite data available.

The well of the 15-3 Oil Co. starts in the white sands of the undifferentiated Miocene, near the contact with the overlying bluish San Pablo strata, where the beds dip about $50^{\circ} \mathrm{S}$. A small amount of light-gravity oil is said to have been obtained at a depth of 640 feet. This was probably not far from the top of the Cretaceous. The well was continued to a depth of 1,200 feet, but no other sands were reported. With the possible exception of the old Doane (?) well the well of the 15-3 Oil Co. is located more advantageously than any of the others to test the lower sands of the undifferentiated Miocene and has given those beds a fair test in this locality.

The Independence well has been drilled since the writers' visit to the region. It starts either in the basal beds of the undifferentiated Miocene or in the Cretaceous and continues in the latter to the bottom, at a depth of 1,700 feet. Small "showings" of oil and gas were reported at various depths.

The Alisal well starts in the middle part of the undifferentiated Miocene, penetrating it and entering the Cretaceous beds below. 
The log of the well, kindly furnished by Mr. G. Mendenhall, superintendent of the Alisal Co. in 1910, is given below:

Log of Alisal Oil Co.'s well No. 1, in sec. 15, T. \& S., R. 8 E.

\begin{tabular}{|c|c|c|c|c|c|}
\hline & $\begin{array}{l}\text { Thick- } \\
\text { ness. }\end{array}$ & Depth. & & $\begin{array}{l}\text { Thick- } \\
\text { ness. }\end{array}$ & Depth. \\
\hline & Feet. & Feet. & & & Feet. \\
\hline $\begin{array}{l}\text { Yellow sand. } \\
\text { Gray sand... }\end{array}$ & & $\begin{array}{r}0-20 \\
20-25\end{array}$ & $\begin{array}{l}\text { Soft shale or clay. } \\
\text { Shell. }\end{array}$ & $\begin{array}{r}115 \\
3\end{array}$ & $\begin{array}{l}310-425 \\
425-428\end{array}$ \\
\hline Streak of brown shaic; & & & Shale............. & 113 & $428-541$ \\
\hline traces of oil & 2 & $25-27$ & Shell.. & 3 & $541-544$ \\
\hline Gray sand..... & 43 & $27-70$ & Gray sand, gas and oil. & 60 & $544-604$ \\
\hline Brown tough sand...... & 30 & $70-100$ & Shells, shale, and bowlders.. & 20 & $604-624$ \\
\hline Gray sand; traces of oil.... & 35 & 100-135 & Hard sand shell........ & 5 & $624-629$ \\
\hline Brown shale.... & 35 & $135-170$ & Soft light sand .... & 35 & $629-664$ \\
\hline Gray sand; a little gas. & 30 & $170-200$ & Hard gray sand ..... & 10 & $664-674$ \\
\hline Shale... & 10 & $200-210$ & Brown shale.... & 150 & $674-824$ \\
\hline Soft light-colored sand. & 5 & $210-215$ & Blue clay... & 20 & $824-844$ \\
\hline Light-gray sand; a little & & & Gray sand shell...... & 3 & $844-847$ \\
\hline oil .............. & 55 & $215-270$ & Blue sandy shale..... & 15 & $847-862$ \\
\hline Hard shale or slate.. & 10 & $270-280$ & Light-blue shale. & 34 & $862-896$ \\
\hline Soft rotten sand. & 5 & $280-285$ & Gray sand with water.... & 48 & $896-944$ \\
\hline Shale.. & 20 & $285-305$ & Blue clay.................... & 35 & $944-979$ \\
\hline Hard stre & 5 & $305-310$ & & & \\
\hline
\end{tabular}

The writers' interpretation of this log is that the beds penetrated to a depth of about 270 feet are part of the undifferentiated Miocene and those below that depth are Cretaceous. The oil sand penetrated between 544 and 604 feet is evidently in the Cretaceous. This sand, it is said, was capable of producing a few barrels a day of light-gravity oil, and at the time of the writers' visit in October, 1910, was pumping between 5 and 10 barrels of fluid, of which at least 75 per cent was water.

A sample of oil claimed to have been obtained from the tank at the Alisal well was furnished to the writers by Mr. E. P. Newhall, of Livermore. It is said that the oil has stood some time in the tank, and it has probably lost some of its lighter and more volatile constituents. This sample was kindly examined by Mr. David T. Day, of the United States Geological Survey, who reported as follows:

Synopsis of oil from the Alisal well, near Tesla, Cal.

Color, brown.

Specific gravity at $60^{\circ} \mathrm{F} ., 0.8766\left(29.7^{\circ}\right.$ Baumé).

Distillation:

Begins to boil at $175^{\circ} \mathrm{C}$.

Gasoline, none.

Boiling between $150^{\circ}$ and $300^{\circ}$ (kerosene). per cent by volume.. 48 Specific gravity, 0.8279 (39.1 $1^{\circ}$ Baumé).

Residuum...................................... 52

Specific gravity, $0.9272\left(21^{\circ}\right.$ Baumé).

100

Paraffin .......................... per cent by weight.. $\quad 5.4$

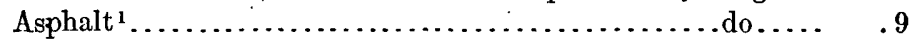

\footnotetext{
1 In this synopsis, as in that of the oil from the Snelling well in The Vallecitos (p. 131), the asphalt reported is that which can be precipitated out by means of light gasoline, according to Holde's method.
} 
The wells of the W. M. \& S. Co. start in the lower part of the undifferentiated Miocene and enter the underlying Cretaceous. Small quantities of oil and gas are reported from the wells, but no oil has been pumped.

The old Doane (?) well started in the steeply dipping bluish beds of the San Pablo formation, but no data are available as to the depth reached, or as to whether any indications of oil were encountered.

A well was drilled by the Tracy Oil Co. at the edge of the San Joaquin Valley in the E. $\frac{1}{2}$ sec. 33 , T. 2 S., R. 4 E., about a mile east of Midway. This well started in the bluish beds of the San Pablo formation and was drilled to a depth of over 3,100 feet. Slight "showings" of oil are reported at various depths, but evidently no appreciable amount of oil was obtained. South and west of the well the undifferentiated Miocene beds rest upon Cretaceous sandstones and shales, the equivalents of those exposed along the Altamont anticline which are believed to be part of the Panoche formation. It is of course possible, but there is no reason for believing it probable, that the Moreno formation (Upper Cretaceous) underlies the undifferentiated Miocene and San Pablo formations beneath the San Joaquin Valley east of Midway. The structure here can not be considered favorable for the collection of oil. About 2 miles south of the well the beds are broken by many small faults which bring Cretaceous strata to the surface in isolated areas. North of this locality the undifferentiated Miocene and San Pablo formations dip at irregular angles toward the north and northeast, but west of the well they gradually assume a more nearly north-south strike and dip to the east. This bending is slight, yet it may be compared to a very faint synclinal fold which plunges abruptly to the northeast. It seems reasonable to suppose that if oil occurs in the rocks underlying the San Joaquin Valley it would not tend to collect in this basin but, as in the region to the south, would gather along the summit and flanks of the anticlines. On the whole there seems to be nothing to recommend this locality.

\section{ALTAMONT ANTICLINE AND OUTLYING AREAS.}

A broad, low anticlinal fold passes through the hills near Altamont and extends southeastward for about 4 miles, dying out in the hills near Patterson Pass. Along the axis of this fold are exposed massive and concretionary sandstones, sandy shale, and fine-grained clay shale of Cretaceous age which are believed to be the equivalent of part of the Panoche formation exposed to the south. None of these beds appears to contain any considerable amount of organic material, and none of them shows surface indications of petroleum. As they are believed to lie stratigraphically below the oil-producing measures of the region to the south, and as they show in themselves 
no signs of petroleum, it is believed improbable that any considerable quantities of oil will be found in them. Two wells were drilled by the Standard Oil Co. along the axis of this fold, one to a depth of 1,090 feet, the other to 2,878 feet. In the deeper well a "showing" of oil was reported at 1,275 feet, but no oil was found in the other well.

A well is said to have been drilled to a depth of about 1,100 feet 15 or 20 years ago at the edge of Livermore Valley about 2 miles west of Greenville, approximately in sec. 26, T. 2 S., R. 2 E. At a depth of about 600 feet a considerable flow of gas is said to have been encountered.' This well starts in the beds mapped as undifferentiated Miocene, in an area of considerable disturbance, and may or may not have gone through the Miocene into the underlying older rocks. About $1 \frac{1}{2}$ miles to the east these undifferentiated Miocene strata rest upon Cretaceous beds that are the equivalent of those exposed along the axis of the Altamont anticline southeast of Altamont, and there is no reason to believe that petroleum-bearing beds would be encountered at depth.

About half a mile northeast of Tesla along the road between that place and Livermore a well was drilled some years ago to a depth, it is said, of about 1,800 feet, without obtaining any trace of oil. This well was drilled in a faulted zone where the Tejon, undifferentiated Miocene, and San Pablo formations are brought together, and the exact stratigraphic position of the beds in which it starts is not known. The beds on either side of the road dip very steeply, and the structure is very unfavorable for the collection of oil.

\section{CONCLUSIONS REGARDING THE TESLA DISTRICT.}

The oil found on the Hamilton ranch east of Livermore Valley occurs both in Cretaceous rocks which are probably, though not certainly; in the basal part of the Moreno formation, and in the undifferentiated Miocene beds. The latter are the beds from which the oil exudes at the surface, the former those in which some of the wells have found oil at depth. The undifferentiated Miocene, because of its lithologic character and stratigraphic position, is evidently more suited to act as an oil reservoir than the sandy beds interstratified with the Cretaceous shale. They are thicker and much more porous than the Cretaceous beds, but, a probably more significant fact, they rest upon the truncated edges of the Cretaceous. Thus any petroleum existing in the finer-grained Cretaceous beds might easily and probably would migrate along the budding planes or along. the sandy beds into the overlying porous blanket of sand in the undifferentiated Miocene. It is from these basal beds of the Miocene that the possibility of obtaining oil seems best. Although oil has collected in the sandy beds interstratified with the Cretaceous shale, and although, 
as has been shown by the Alisal well, small quantities of oil may be produced by wells penetrating these beds, it is believed by the writers that the lower beds of the overlying Miocene will prove more profitable to prospect than the Cretaceous.

All the drilling on the Hamilton ranch has been confined to the two gulches in which the seeps occur, the wells being located on the south flank of a somewhat irregular anticline and approximately along a line where the dip of the beds increases abruptly. Owing to the erroneous idea held by most of the drillers that the beds dip toward the north, many of the wells have been started north of the point at which the oil exudes from the undifferentiated Miocene beds, and consequently in beds stratigraphically lower. These wells have passed through a very small thickness of undifferentiated Miocene before they entered the Cretaceous beds. The old well of the 15-3 Oil Co., situated between the well of the Independence Oil Co. and the old Hamilton ranch house, probably derived the oil it is reported to have produced from the basal sands of the undifferentiated Miocene. If so it is the only well that has yet obtained appreciable quantities of oil from those beds. Near the seeps the undifferentiated Miocene beds have to a very large extent been removed by erosion, and the cover overlying the oily beds in the area where the dip is low is insufficient to have prevented the escape of the oil. The general structural features typical of the region near the Hamilton ranch continue eastward nearly to Carnegie. Through much of this area the cover of Miocene beds has not been so largely removed as it has on the Hamilton ranch. Where this cover has been removed to no great extent and where the peculiar irregular fold typical of the structure at the Hamilton ranch exists, the conditions are favorable for the collection and retention of oil in the lower beds of the Miocene. These conditions are best fulfilled about 2 miles southeast of the Hamilton ranch, near. sec. 24, T. 3. S., R. $3 \mathrm{E}$.

Another area which offers some inducement is the area of low dips from 1 to 2 miles north of Carnegie. The beds here are folded into an irregular and somewhat broken dome which is virtually the continuation of the anticline trending east through the hills just north of the Hamilton ranch. The shale of the Moreno formation occurs along the south side of Corral Hollow Creek between Carnegie and Tesla and probably continues both northward across the creek and eastward beneath the cover of the Tertiary formations. Should it continue northward, the fold north of Carnegie would offer a favorable structure for oil which may have been formed in this shale to collect. The oil, if present, would tend to gather in the basal sandy bed of the overlying Tertiary.

In conclusion, it may be said that the probability of obtaining a large quantity of oil in the Tesla district is remote, but that wells 
producing a little light-gravity oil may possibly be obtained in very small areas. Such wells may derive their oil either from sandy beds in the Cretaceous or from the lower beds of the unconformably overlying Tertiary, the latter offering the better chances. The areas which offer some inducements for drilling are a narrow strip along the south flank of the anticline which trends east through the hills north of Tesla, where the dip of the beds steepens abruptly, and an area of low dips at the east end of that anticline, where the surface is formed by the slightly dipping undifferentiated Miocene and San Pablo formations. Outside of these two areas the possibility of obtaining oil seems very poor, and the writers believe that drilling in other localities will prove a waste of money.

\section{ORIGIN OF THE OIL.}

\section{GENERAL DISCUSSION AND CONCLUSIONS.}

The oil-bearing zones of this region are the two diatomaceous and foraminiferal shale formations-the Moreno (Upper Cretaceous) and the Kreyenhagen (Oligocene ?) - and the sandy beds lying immediately above them. This fact points significantly to the two formations as the sources of the oil, and the writers firmly believe that the petroleum was derived from the organic matter once contained in the myriad shells of minute organisms of which these formations are largely composed. The main geologic reasons for this conclusion are outlined in the succeeding paragraphs.

The strata comprised in the Moreno and Kreyenhagen formations compose a relatively small part of the total succession of sedimentary beds exposed; yet it is in or about them that the oil is found. The close association of the petroleum with these bodies of organically formed shale leaves practically no doubt that. in some way the oil owes its presence to them. In bringing about such accumulations the shales must have acted in one of two ways. Either their peculiar character resulted in a concentration in and near them of the oil that had been disseminated through great thicknesses of strata which are now barren, or else they were the original source of the petroleum. The first hypothesis is the less natural of the two and has little if anything to support it. If this hypothesis were entertained it would be necessary to suppose (a) that there was some original source for the oil other than these shales, of the existence or character of which there appears to be no evidence whatever; $(b)$ that the oil had traveled through thousands of feet of sandy and shaly strata without leaving any trace, only to gather near the shales of organic origin and remain confined in sandy beds no more suitable for its retention than those through which it would have had to pass; $(c)$ that the shales of organic origin had a mysterious power of attracting and 
holding oil, a supposition which is contradicted by the fact that the shale beds themselves usually contain only minor amounts of petroleum, whereas the associated sandy beds contain great stores of it; and $(d)$ that the vegetable and animal matter of the organisms whose siliceous and calcareous skeletons are present in such profusion in the shales became dissipated without leaving any trace.

In the light of the evidence available the conclusion that the diatomaceous and foraminiferal shales gave rise to the petroleum appears to be the only logical one to adopt. It is supported in the Diablo Range by the following facts: (a) So far as known reservoirs of oil occur only in intimate association with the shales of organic origin, of which there are two main bodies, the Moreno (Upper Cretaceous) and the Kreyenhagen (Oligocene ?); (b) oil occurs in and immediately above each of these shales-a light-gravity oil containing paraffin wax in association with the former, and a heavier asphalt oil in association with the latter-giving reason to believe that each has produced a distinctive product; $(c)$ these shales contain by far a greater amount of material of organic origin than is to be found in any other part of the geologic column in this region, and if the oil was derived from any organic source at all it must have come from them, for they are the only deposits representing an amount of organic matter adequate to produce the large quantity of petroleum present; $(d)$ there is no evidence of an appreciable quantity of oil, if any at all, in the strata below these shales and their associated beds. If the petroleum had originated at great depth through inorganic processes it would of necessity have penetrated the formations that underlie the present oil-bearing sands, and there seems to be no good reason why the oil should not have halted in these lower formations. The sandy beds that overlie the shales and are the principal reservoirs of oil are in no wise different from the non oil-bearing detrital beds in this and in other regions, and there is no reason for believing the oil to be indigenous in them. Their importance as oil reservoirs varies directly in accordance with their proximity to the organically formed shales.

Similar facts support this theory in at least most of the other places in the State where signs of oil are known and in every place that has so far been carefully studied. It may truthfully be said with regard to every one of the important oil fields of California that the great bulk of the oil occurs in close association with shale formations of the same peculiar type as those just mentioned, in stratigraphic positions where its presence can be accounted for logically only on the assumption that it came from such formations. It is highly significant, moreover, that these formations, although composed of similar material, are not of the same age in all the fields but occur at various positions in the geologic column. The constant feature in the strati- 
graphic position of the oil accumulations is their relation to such formations, and not their occurrence at any constant geologic horizon or in beds of any particular age.

In the following paragraphs is given a brief summary of the occurrence and range of the petroleum in all the important California fields, every one of which gives a striking illustration of the intimate relation existing between the oil and organically formed shale. In most of these fields the main reservoirs are not the shaly strata themselves, but, as would naturally be expected if the oil originated in the shale, the adjacent pervious sandy strata. As a rule most of the oil is found permeating a thickness of a few hundred feet of sandy beds just above the shale. Good reservoirs are also afforded by sandy zones interstratified with the shale and by those immediately underlying it.

At almost all the many places along the coast where seeps occur, from Point Arena south and in the important Santa Maria, Los Angeles, Puente Hills, and Fullerton fields, the petroleum occurs in sandy beds adjacent to the shale of organic origin in the Monterey group (lower or middle Miocene) or the similar Miocene beds that have been described under the name Puente formation but are generally considered to be equivalent to the Monterey in age. In these places thick deposits of organic origin are lacking in other parts of the geologic column so far as known.

In the Santa Clara River fields of Ventura and Los Angeles counties petroleum occurs in quantity in the foraminiferal and diatomaceous shales of Miocene age that have been described under the names Vaqueros and Modelo and in their associated sandy beds. Oil is also distributed through a considerable thickness of supposed Eocene and Oligocene strata, which at some horizons are of organic origin. In the Summerland field of Santa Barbara County the principal reservoirs of oil are in the shale of the Monterey group and in the overlying sandy beds, but here also the Eocene or Oligocene (?) beds contain some petroleum. Until further studies of the occurrence of the oil in the pre-Miocene formations of these two last-named regions have been made it can not be said how completely the theory under discussion is borne out. It is strongly suspected that some of the pre-Miocene shales in that part of the State, which contain material of organic origin, may correspond in stratigraphic position with those in the Diablo Range and have a similar relation to the oil.

In the great Temblor Range field, along the western border of the San Joaquin Valley, the oil is everywhere closely associated with and appears to be derived from a great succession of diatomaceous and foraminiferal shales, many thousands of feet thick, that occupy about the same position in the stratigraphic column as the main oil-bearing beds of the coast. This terrane is believed to represent not only the 
shale of the Monterey group but a later portion of the Miocene series as well. No materials of organic origin of any consequence have been discovered other than those mentioned, and except in the sandy beds immediately at the base of this shale no oil is found in the strata exposed below them, which include the Jurassic (?), Cretaceous, Eocene, and lower Miocene.

In the Kern River field, on the east side of the San Joaquin Valley, the quantity of shale of organic origin present at the outcrops is relatively small compared with that in any of the other fields, but it is present nevertheless, and the oil like the most important accumulations elsewhere, occurs in the porous sand overlying the formation in which the shale occurs. The shale and the interstratified sandy beds are shown by the fossils they contain to be the stratigraphic equivalent of at least part of the formations made up of diatomaceous shale in the Temblor Range on the opposite side of the valley. The formations are somewhat different on the east side of the valley, being more sandy, but it is believed that this change is gradual and that under the alluvium of the San Joaquin Valley. not far west of the edge of the Kern River field the amount of diatomaceous shale is much greater than where the beds are exposed in the hills east of the field. The oil is believed to have risen from the diatomaceous shale into the unconformably overlapping sand and gravel beds, gathering perhaps in part from strata underlying the field but probably in the main from beds lying beneath the San Joaquin Valley.

Finally, in the region discussed in the present report and in the contiguous Coalinga district the shale of the Monterey group is absent or insignificant in size and the oil does not appear to have originated in the portion of the column where it is usually found elsewhere. Instead it occurs in and near two older formations of organic originthe Moreno (Upper Cretaceous) and the Kreyenhagen (Oligocene?) which so far as present knowledge goes are peculiar to this region. A minor quantity of diatomaceous shale representing approximately the same epoch of deposition as the lower portion of the shale of the Monterey group of the coastal region occurs locally in the older beds of the Monterey group, mapped as the Vaqueros formation. These may have produced some of the oil. Diatomaceous shale equivalent to the shale of the Santa Margarita (?) formation of the Temblor Range field and believed to be of upper Miocene age makes its appearance not far south of the Coalinga field, but it seems to have no relation to the known occurrence of oil in that field or in the extensive region to the north described in this report. A little farther south, where it is well developed and is folded in such a way as to afford a favorable reservoir for the retention of oil it shows evidence of oil, which presumably originated in it. Still farther south, in the Tem- 
blor Range field, it underlies the large productive sands and probably is quite as likely an original source of petroleum as the underlying organic shale of the Monterey group.

The idea that diatoms might be looked to as the ultimate source of petroleum in the oil fields of the southern half of California grew into currency among California geologists because such a hypothesis naturally suggested itself to those familiar with the diatomaceous shale of the Monterey group and its characteristic impregnation with oil. This formation is of marked individuality and prominence through the western Coast Ranges, and two of its most pronounced characteristics, its diatomaceous and bituminous nature, are linked together in a way that forced attention upon their causal relationship. When detailed studies of the occurrence of petroleum in California were begun, and more and more instances of the presence of oil in this formation and in close association with it were discovered, the idea that the oil originated from the organisms whose remains to a large extent make up the shale became increasingly probable. Now that it is being discovered that there are several other formations of almost identical character but different age, that these other formations are similarly characterized by the presence of oil, and that in all the more important fields in California the petroleum occurs in association with one or another of these formations, the evidence in favor of the hypothesis begins to amount almost to proof.

The shales of organic origin that have been mentioned were originally marine deposits of fine silt mingled with enormous quantities of the remains of diatoms and foraminifers. The foraminifers are minute animal organisms of many rounded and elongate forms, varying in length from several millimeters to small fractions of a millimeter and surrounded by hard calcareous shells. The diatoms are microscopic vegetable organisms of somewhat similar shapes and even smaller sizes, contained in almost completely closed shells of silica. Most of these organisms lived at or near the surface of the ocean, but when they died they sank to the bottom. The soft parts of many probably decayed or were devoured by larger organisms, only the hard shells becoming buried in the silt at the bottom. But millions of whole organisms must have been entombed in the ooze and remained for a long period buried under increasing thicknesses of superimposed sediments and undergoing slow alteration. It is certain that a large amount of organic material remains inclosed in the ooze at the sea bottom, because it may be found in at least a part of the frustules dredged up in the present oceans, and has even been reported in fossil material of this kind. It has been noted that when ooze is brought to the surface decomposition sets in and a foul odor is given off. 
At the sea bottom decomposition of organic matter is probably greatly retarded by low temperature and the scarcity of oxygen. If any bacterial action takes place it is probably effected through the agency of anaerobic bacteria, which produce decay much less rapidly ${ }^{\circ}$ than those which would be present if a good supply of oxygen were available. It is not known to what extent putrefaction is carried on under such conditions and what are the products of such biochemical action, but the writers believe it improbable that liquid hydrocarbons are the result of such action alone. Nor, so far as they are aware, have such materials been reported in the ooze of the present oceans, except in shallow water near certain oil fields, where petroleum seeps occur in the sea. The completion of the process of change that finally results in the formation of petroleum is believed to be the result of other geologic influences, such as the phenomena accompanying earth movement. Among these phenomena it is probable that pressure and moderate heat continued for an almost indefinite period are influential.

It can not be said whether both the diatoms and the foraminifers or only one of these types of organisms furnished the organic matter from which the oil was produced, or whioh was the more important, but it seems probable that both contributed, with the possible addition of ingredients from still other organisms. Owing to the fact that the organic substance of plants is less readily decomposed than animal matter and would therefore be more certain to persist within the deposit until well buried and sealed, the diatoms are believed to have been the greatest contributors.

SUPPLEMENTARY STATEMENTS RELATING TO THE ORIGIN OF OIL IN THE DLABLO RANGE.

The general facts and conclusions regarding the occurrence and origin of the oil of the California fields have been given in the preceding section. It remains to add certain data obtained in the study of the Diablo Range which will make the statement more complete and convey a fuller idea of the facts upon which the above conclusions rest.

It has been stated that the concentration of the petroleum in and near the Moreno and Kreyenhagen formations points significantly to the shales of organic origin as the factor controlling the stratigraphic distribution of the oil. This significance is emphasized when the thickness and character of the oil-bearing strata are considered in comparison with those of the barren beds. The total thickness of the part of the geologic column through which oil is known to range and to which the shales of organic origin are confined would be comprised within a maximum of 10,000 feet, whereas the older and younger 
portions of the column, which are barren of oil, include over three times that thickness. As a matter of fact there is no single section in which the oil ranges through a thickness nearly so much as 10,000 feet. In the Coalinga field and also in The Vallecitos, where both the oldest and youngest of the oil-bearing formations of the region are represented - the Moreno (Upper Cretaceous) and the Jacalitos (upper Miocene) - the total thickness of these and the beds between them in any section would not be over 4,500 feet. Of this amount about 2,000 feet represents the combined thickness of the two formations that are composed largely of the remains of minute marine organisms. Aside from the organic nature of the shale in the oilbearing portion of the stratigraphic column, no feature is known which might have a bearing on the occurrence of oil and which would serve to distinguish it from the part of the column barren of oil. Thousands of feet of beds below and above the petroliferous zone are in other respects of a character as favorable for the accumulation of oil as the beds in the productive zone.

Taking the region as a whole each of the two shale formations mentioned may be said, roughly, to include a thousand feet of beds that are predominantly of organic origin. Both of these formations show surface signs of being oily in various places separated by long distances, and in drilling oil has been found in both at depth.

In almost every place where these shale formations are oily the sandy strata that overlie them, of whatever age such sandy beds happen to be, are petroliferous also; but on the other hand, no strata contain oil in the places where the shale formations of organic origin are barren of oil or absent, except possibly in the Tesla area, regarding which the evidence available does not permit definite assertions one way or the other.

It is believed entirely probable that the shale formations of organic origin have everywhere contained oil. They show evidences of it at every point where the structure is at all favorable for its accumulation; and moreover, wherever they give no sign of containing petroleum their barrenness is readily explainable on structural grounds, the structure being such as' would make it surprising rather than otherwise if any oil had remained. The same can not be said of the strata below the shale of the Moreno formation-the strata to which it would be almost necessary to look for a source, or at least a reservoir, of the oil if it were concluded that the oil did not come from the shale. On the contrary, these older beds are nowhere known to be oily. At several places the Panoche formation, comprising the upper Cretaceous sandstone and shale older than the Moreno, is folded into anticlines highly favorable for the gathering of oil if any were present, but none makes its appearance either at such points or elsewhere. 
Examples of such folds are the Coalinga anticline along Joaquin Ridge, the Ciervo anticline along the Griswold and Tumey hills, and the Altamont anticline northeast of Livermore. Along the Altamont fold deep wells were drilled in the Panoche formation without success. The inevitable conclusion is that the pre-Moreno strata do not contain any appreciable quantity of petroleum, and can not have been the source of that which now exists in the higher beds.

The foregoing facts point emphatically to the shale as the source of the petroleum. The evidence is strengthened still more by the indications that not only one but both of these formations produced oil, and that they acted independently, giving rise to petroleum of different qualities. The following facts bear upon this conclusion:

1. These two formations are not coextensive, and each is oil bearing in certain places where the other is lacking or barren of oil. As an illustration may be cited the presence of oil in the Moreno formation on the Ciervo anticline at a distance of several miles from the locality where the Kreyenhagen shale occurs. The latter formation, in addition to being separated by a great thickness of beds from the Moreno and affected by different structural conditions, is barren of oil there. Another illustration is afforded by the indications of petroleum, although slight, in the shale of the Moreno formation along the south side of San Carlos Bolsa east of New Idria, where this formation is separated from the Kreyenhagen shale by many thousand feet of steeply dipping barren strata. It can not be absolutely affirmed that the oil of the Kreyenhagen shale did not rise from the lower shale, but the evidence does not favor such a supposition. The best illustration of the independence of this formation as a source of oil is afforded in the Kreyenhagen field, at the south end of the Coalinga district, where not only the Kreyenhagen shale but the overlying Vaqueros and underlying Tejon are soaked with oil in spite of the entire absence, so far as known, of the Moreno formation.

2. Further evidence of independence is to be found in the differences in the character of the oil found in the two shale formations in the Coalinga field, where they are both oil bearing in the same area. There the Moreno formation and the Martinez (?) or Tejon formations (Eocene) above it yield oil of light gravity containing paraffin wax, whereas the Kreyenhagen shale and the overlying Miocene sands contain a much heavier asphalt oil. In the areas where these formations are present outside of the Coalinga district the chemical character of the oils is not so well known, but the data obtained in the Vallecitos district and discussed in the preceding section of this report indicate that the same distinction between the two formations holds good. 
The mode of occurrence of oil in the Tesla district has been mentioned in passing as a possible exception to the uniform conditions of its occurrence in other parts of this region. The facts regarding this district and such conclusions as may be drawn are discussed fully on pages 186-194. It will therefore suffice to say here that oonclusive evidence as to the source of the oil of that vicinity is lacking. The Moreno formation is a possible source and all things considered seems the most probable one, so that the occurrence there may in reality be entirely in harmony with conditions elsewhere.

In considering the possible sources of the petroleum of this region mention should be made of certain minor masses of originally organic material which occur in strata associated with the two formations of organically formed shale already mentioned and which might conceivably have contained the material from which some of the oil was produced. Consideration of them serves to emphasize the importance of the two main organically formed shales rather than to suggest other possible sources. Those worthy of mention are the somewhat foraminiferal clayey beds of the Martinez (?) formation, which overlie the Moreno; the lignitio beds of the Tejon formation; and the diatomaceous shale of the Vaqueros.

The fine-grained beds of the Martinez (?) contain many impressions of foraminifers, but are composed predominantly of detrital material and not of organic remains. The foraminifers are scattered through the sediment and are nowhere packed closely together so as to make up the mass of the deposit like the organisms in the shales of the Moreno and Kreyenhagen formations. Though these foraminifers may have contributed something to the total oil supply, there is no good indication of it, and they could hardly have been large contributors.

As described elsewhere, the Tejon formation is characterized by interbedded strata of coal and carbonaceous shale containing abundant fragmental impressions of plant remains such as marsh grasses and leaves. Besides these visible remains of the larger plants the carbonaceous beds may contain remains of microscopic organisms, but in specimens examined under the microscope the hard parts of diatoms or of foraminifers were not seen. It may be that such small organisms were once present in these beds, but that their skeletons, instead of being preserved as they are in the Moreno and Kreyenhagen formations, were dissolved in the organic acids produced in the alteration of the larger terrestrial vegetation. It does not seem improbable that the buried remains of the larger land and water plants, either alone or together with the micro-organisms, should those have existed in abundance, might, under proper conditions, have given rise to oil. The Tejon formation, however, is one of the 
thinner formations in the region, rarely being over a few hundred feet thick, and the shaly portion is usually but a small part of the whole. The amount of vegetable matter which may have once been contained in the Tejon formation is therefore believed to be entirely too small to have been a possible source of much petroleum. It would certainly appear insufficient to have produced the vast quantity occurring in the Coalinga district.

Diatomaceous shale is interbedded with the sands of the Vaqueros in certain parts of the region, but no conclusion as to whether oil did or did not originate in it would be warranted. The aggregate thickness of the shale beds varios from about 20 feet in the Coalinga field, where several thin layers occur, to 400 feet or more in The Vallecitos, but locally the shale is absent. Its character is the same as that of the Kreyenhagen shale, and as it occurs in the midst of the formation that is the natural reservoir for any oil that may have come from the Kreyenhagen the evidence as to whether or not it contributed part of the oil now contained in the sandy beds is obscured. No reason is known why it should not have produced oil, and it is not unlikely that it did. Even if it did, however, it does not lessen the probability that the bulk of the petroleum in the Vaqueros came from the Kreyenhagen. In the Coalinga field, where the greatest volume of oil occurs, the quantity of matter of organio origin in the Vaqueros is insignificant, and in The Vallecitos, where the organically formed shale in the Vaqueros is best developed, the most abundant surface signs of oil are in the Kreyenhagen shale and the basal beds of the Miocene in contact with that shale.

Aside from these three minor shales of organic origin no other important aggregates of animal or plant remains occur in the rocks of this region. Locally there occur abundant molluscan and other fossils, but in no place in any quantity that could be considered unusual or significant. There is no true body of limestone in this region. In fact, the scarcity of limestone in the oil regions of California is an important and characteristic feature of the geology of the Paoific coast province which has a bearing on the problem in hand. The place of great bodies of limestone is here assumed by the diatomaceous shale.

After a study of the extensive region of the Diablo Range to which the above statements apply, it appears to the writers that the facts outlined leave no plausible alternative for the conclusion that the petroleum is indigenous to the two main shales of organic origin. It is also believed that each of the two formations gave origin to oil of a rather distinct character, but the validity of the first and main conclusion does not necessarily rest on the truth of the second. 


\section{AREAS WITHDRAWN FROM ENTRY.}

In the areas listed below, which lie within the region treated in the present report, the unappropriated public lands have been withdrawn from all forms of entry "in aid of legislation affecting the use and disposal of petroleum lands belonging to the United States." These areas comprise those lying north of the Coalinga district in which there appears to be a reasonable probability of obtaining oil in commercial amounts either at present or in the not remote future. For a full discussion of the probabilities of obtaining oil in these areas the reader is referred to the section on the occurrence of oil in different areas and future possibilities. For a list of the withdrawn lands in the Coalinga district lying south of the north line of T. $19 \mathrm{~S}$. the reader is referred to the report on that district. ${ }^{1}$

Withdrawn lands on west border of San Joaquin Valley north of Coalinga.

[Mount Diablo base and meridian.]

T. 3 S., R. 3 E., sec. 9 , S. $\frac{1}{2}$ of N. $\frac{1}{2}$, S. $\frac{1}{2}$;

sec. $10, \mathrm{~S} . \frac{1}{2}$ of N. $\frac{1}{2}, \mathrm{~S} . \frac{1}{2}$;

sec. 11, S. $\frac{1}{2}$;

sec. 13, W. $\frac{1}{2}$, SE. $\frac{1}{1}$;

secs. 14 to 16 , inclusive;

sec. $22, N . \frac{1}{2}$ of N. $\frac{1}{2}$;

sec. 23, N. $\frac{1}{2}$;

sec. 24, N. $\frac{1}{2}$, N. $\frac{1}{2}$ of S. $\frac{1}{2}$, SE. $\frac{1}{4}$ of SE. $\frac{1}{4}$.

T. 3 S., R. 4 E., secs. 19 to 23 inclusive;

secs. 26 to 28 , inclusive;

sec. $29, \mathrm{~N} . \frac{1}{2}, \mathrm{~N} . \frac{1}{2}$ of $\mathrm{S} . \frac{1}{2}$;

sec. $30, \mathrm{NE} . \frac{1}{4}, \mathrm{NE} . \frac{1}{4}$ of NW. $\frac{1}{4}$;

sec. $33, \mathrm{NE}$. $\frac{1}{4}$ of NE. $\frac{1}{4}$;

sec. $34, N . \frac{1}{2}$ of N. $\frac{1}{2}$;

sec. $35, \mathrm{~N} . \frac{1}{2}$ of N. $\frac{1}{2}$.

T. 16 S., R. 10 E., secs. 7 to 9 , inclusive;

sec. 13, S. $\frac{1}{2}$;

secs. 14 to 30 , inclusive;

secs. 34 to 36 , inclusive.

T. 17 S., R. 10 E., sec. 1, all.

T. 16 S., R. 11 E., sec. 18 , SW. $\frac{1}{4}$, S. $\frac{1}{2}$ of SE. $\frac{1}{4}$;

sec. 19 , all;

sec. 20 , SW. $\frac{1}{4}$ of NE. $\frac{1}{4}$, W. $\frac{1}{2}$, SE. $\frac{1}{4}$;

sec. 21 , SW. $\frac{1}{4}$ of SW. $\frac{1}{4}$;

sec. $25, \mathrm{SW} . \frac{1}{4}, \mathrm{~S} . \frac{1}{2}$ of SE. $\frac{1}{4}$;

sec. $26, \mathrm{~S} . \frac{1}{2}$;

sec. 27, SW. $\frac{1}{4}$ of NW. $\frac{1}{4}$, S. $\frac{1}{2}$;

sec. 28 , W. $\frac{1}{2}$ of NE. $\frac{1}{4}$, SE. $\frac{1}{4}$ of NE. $\frac{1}{4}$, W. $\frac{1}{2}$, SE. $\frac{1}{4}$;

secs. 29 to 36 , inclusive 
T. 17 S., R. 11 E., secs. 1 to 5 , inclusive;

sec. 6 , lots $1,2,3,4,5,6,7,8,10,11,12,13,14,15,16,17,18$, 19, E. $\frac{1}{2}$

sec. 7 , lots $1,2,3,4,9,10,11,12,13,14$;

secs. 8 to 15 , inclusive;

sec. 16, N. $\frac{1}{2}$, NE. $\frac{1}{4}$ of SW. $\frac{1}{4}$, SE. $\frac{1}{4}$;

sec. 17, N. $\frac{1}{2}$;

sec. 21, NE. $\frac{1}{4}$;

sec. $22, \mathrm{~N} . \frac{1}{2}$ of NE. $\frac{1}{4}, \mathrm{NW} \cdot \frac{1}{4}$;

sec. $23, \mathrm{~N} . \frac{1}{2}$ of N. $\frac{1}{2}$;

sec. $24, N$. $\frac{1}{2}$.

T. 16 S., R. 12 E., sec. 8 , NE. $\frac{1}{4}$ of NE. $\frac{1}{4}$;

sec. 9, N. $\frac{1}{2}$, NE. $\frac{1}{4}$ of SW. $\frac{1}{2}, \mathrm{SE} . \frac{1}{4}$;

secs. 10 to 15 , inclusive;

sec. 16, E. $\frac{1}{2}$ of NE. $\frac{1}{4}$;

sec. 21, NE. $\frac{1}{4}$, NE. $\frac{1}{4}$ of SW. $\frac{1}{4}$, S. $\frac{1}{2}$ of SW. $\frac{1}{4}$, SE. $\frac{1}{4}$;

secs. 22 to 28 , inclusive;

sec. 29 , E. $\frac{1}{2}$ of NE. $\frac{1}{4}$;

sec. 30 , lot 4 ;

sec. 31, all;

sec. 32 , S. $\frac{1}{2}$ of NW. $\frac{1}{4}$, SW. $\frac{1}{4}$, SW. $\frac{1}{4}$ of SE. $\frac{1}{4}$;

sec. 33, NE. $\frac{1}{4}$, E. $\frac{1}{2}$ of NW. $\frac{1}{4}$, N. $\frac{1}{2}$ of SE. $\frac{1}{4}$, SE. $\frac{1}{4}$ of SE. $\frac{1}{4}$;

secs. 34 to 36 , inclusive.

T. 17 S., R. 12 E., sec. 1, all;

sec. 2 , all;

sec. 3 , lots $1,2,3,4,5,6,7$, E. $\frac{1}{2}$ of lot 8, N. $\frac{1}{2}$ of SE. $\frac{1}{4}$, SE. $\frac{1}{4}$ of SE. $\frac{1}{4}$;

sec. 4 , lot 1 ;

sec. 5 , lot 4 , SW. $\frac{1}{1}$ of NW. $\frac{1}{4}$, W. $\frac{1}{2}$ of SW. $\frac{1}{4}$, SE. $\frac{1}{4}$ of SW. of SE. $\frac{1}{4}$;

sec. 6 , all;

sec. 7, all;

sec. 8, W. $\frac{1}{2}$ of NE. $\frac{1}{4}$, SE. $\frac{1}{4}$ of NE. $\frac{1}{4}$, W. $\frac{1}{2}$, SE. $\frac{1}{4}$;

sec. 11, all;

sec. 12 , all;

sec. 17 , all;

sec. 18 , all;

sec. 19 , lots $2,3,4,5,6,7,8$.

T. 16 S., R. 13 E., sec. 7, SW. $\frac{1}{4}$ of NE. $\frac{1}{4}$, W. $\frac{1}{2}$, SE. $\frac{1}{4}$;

sec. $8, W . \frac{1}{2}$ of SW. $\frac{1}{4}$, SE. $\frac{1}{4}$ of SW. $\frac{1}{4}$;

sec. 16, SW. $\frac{1}{4}$ of NW. $\frac{1}{4}, \mathrm{SW} \cdot \frac{1}{4}, \mathrm{SW} \cdot \frac{1}{4}$ of SE. $\frac{1}{4}$;

sec. 17, W. $\frac{1}{2}$ of NE. $\frac{1}{4}$, SE. $\frac{1}{4}$ of NE. $\frac{1}{4}, W . \frac{1}{2}$, SE. $\frac{1}{4}$;

secs. 18 to 20 , inclusive;

sec. 21, W. $\frac{1}{2}$ of NE. $\frac{1}{2}$, SE. $\frac{1}{4}$ of NE. $\frac{1}{1}$, W. $\frac{1}{2}$, SE. $\frac{1}{4}$;

sec. 22 , SW. $\frac{1}{4}$ of SW. $\frac{1}{4}$;

sec. $27, \mathrm{~W} \cdot \frac{1}{2}$ of NW. $\frac{1}{4}, \mathrm{SE} . \frac{1}{4}$ of NW. $\frac{1}{4}, \mathrm{SW} . \frac{1}{4}, \mathrm{~W} \cdot \frac{1}{2}$ of SE. $\frac{1}{4}$;

secs. 28 to 34 , inclusive;

sec. 35, W. $\frac{1}{2}$ of SW. $\frac{1}{4}$, SE. $\frac{1}{4}$ of SW. $\frac{1}{4}$.

T. 17 S., R. 13 E., sec. 2 , lots $2,3,4,5,6,7,8$, SW. $\frac{1}{4}$, W. $\frac{1}{2}$ of SE. $\frac{1}{4}$;

secs. 3 to 9 , inclusive;

sec. 10, N. $\frac{1}{2}$, SW. $\frac{1}{4}$, N. $\frac{1}{2}$ of SE. $\frac{1}{1}$, SW. $\frac{1}{\frac{1}{4}}$ of SE. $\frac{1}{1}$;

sec. $11, \mathrm{NW} . \frac{1}{4}, \mathrm{NW} . \frac{1}{1}$ of SW. $\frac{1}{1}$. 


\section{MINERAL DEPOSITS OTHER THAN PETROLEUM.}

No attempt was made to study in detail any mineral other than petroleum. Deposits of various other materials having an economic value occur in this region, however, and notes on those that were encountered in the course of the field work are here inserted. Owing to the poor facilities for transportation in this region the development of its mineral resources is attended with difficulty. Except for the quicksilver mine at New Idria, which is about the oldest continuously operated mine of any mineral in the State, attempts at development have been only sporadic.

\section{QUICKSILVER.}

Within the boundaries of the region that forms the subject of the present report the sedimentary and associated igneous rocks of the Franciscan formation contain deposits of many metallic minerals. In places these minerals are concentrated and form deposits that are at present of economic importance. Chief among these are the quicksilver deposits, of which there are several within the area covered by the map. ${ }^{1}$

The New Idria mines, near the crest of the Diablo Range, in the south end of the region, have been for several years the principal source of quicksilver in the United States. Cinnabar was discovered there in 1853 and this district has produced quicksilver almost continuously since that date. According to published reports of the company, in 1910 the New Idria mines treated 73,208 short tons of ore, obtaining 10,800 flasks of quicksilver; in 1911 the amount of ore treated was 67,706 short tons, and the output 9,750 flasks; in 1912, 76,348 tons and 9,600 flasks; in $1913,76,993$ tons and 9,700 flasks; and in 1914, 62,578 tons and 6,550 flasks.

The ore at New Idria occurs in the altered and highly fractured shale and sandstone of the Franciscan formation, close to the contact with the overlying Panoche formation. Cinnabar occurs as thin films coating the fracture surfaces, as impregnations in the more porous sandstone, and, according to Becker, as fillings in true fissure veins. In places the cinnabar acts as a cementing material binding together the brecciated Franciscan rocks. These, the stockwork deposits described by Becker, are the principal source of the ore. The metal is now obtained entirely from cinnabar, but in the earlier and upper workings a considerable amount of metacinnabarite was found. The ore obtained at present is not so rich as that mined in the early days from the upper workings. The average ore now

1 Becker, G. F., Geology of the quicksilver deposits of the Pacific slope, with an atlas: U. S. Geol. Survey Mon. 13, pp. 301-309, 379-381, 1888. Forstner, William, The quicksilver resources of California: California State Min. Bur. Bull. 27, pp. 119-122, 125-137, 1903. McCaskey, H. D., U. S. Geol. Survey Mineral Resources for 1908 , pt. 1, pp. 686-689, 1909. 
mined yields less than 1 per cent of metal in the furnace, but owing to the large quantities of it mined and treated daily ore yielding less than 0.5 per cent can now be worked at a profit. On the flanks of San Carlos Peak, about 2 miles southeast of New Idria, the same company has opened another deposit, which, like that at New Idria, occurs in the Franciscan formation close to its contact with the Panoche formation.

The De Mexico mine is a small prospect on the headwaters of Arroyo Leona, a tributary of Cantua Creek, in sec. 22, T. 18 S., R. $13 \mathrm{E}$., about 9 miles southeast of New Idria. As at New Idria the ore lies in the Franciscan formation close to its contact with the Panoche formation. The prospect was not visited; but according to Forstner ${ }^{1}$ the cinnabar occurs in sedimentary rocks which form very poor outcrops, being largely masked by serpentine. No work has been done here for several years, but it is said that several flasks of metal were distilled from the ore in a crude retort on the claim.

The Cerro Bonito mine lies in sec. 31, T. 15 S., R. 10 E., about 2 miles south of Llanada. This mine is said to have been worked from 1874 to 1876 . Considerable development work was done and a small reduction plant erected, but the mine has long been abandoned and the workings are now almost completely caved.

The Mercy quicksilver mine is on Mine Creek, in the north end of Little Panoche Valley, about 2 miles west of the Mercy schoolhouse. This deposit, it is said, was first prospected for silver near the middle of last century, and since then work has been done on it at various times. At the time of the writers' visit, in 1910, most of the old tunnels had caved, and only the southernmost one, which had been worked recently, was visited. The ore occurs mainly in dark clayey material along quartz veins which have a general southeast strike and a steep dip. In places these veins contain small aggregates of quartz crystals as much as 2 inches in length, showing that they were in part at least crystallized in open spaces. Small nests of crystals of cinnabar and pyrite are present in the veins and in places a little chalcopyrite occurs and the quartz is stained slightly green. According to Mr. J. Norrish, about 1,300 feet of drifts had been run, but the mine was then idle. A small rotary furnace was located a few hundred feet below the mouth of the tunnel, and a little metal had been produced. In 1912 the mine was sold to the Pacific Quicksilver Co. A 20-ton Scott fine-ore furnace was built and, according to Mr. Norrish, up to February, 1914, about 500 flasks of metal had been produced, but the available ore became exhausted. Early in 1914 the discovery of further bodies of workable ore was reported.

1 Forstner, William, op. cit., p. 119.

S1281 - Bull. $603-15-14$ 


\section{MANGANESE.}

Manganese deposits are found at several localities in the chert beds of the Franciscan formation. The old Ladd mine, ${ }^{1}$ in sec. 2, T. 4 S., R. 4 E., about 5 miles east of Tesla, has been the principal source of manganese in the State and between 1867 and 1879 is said to have produced 5,500 tons of ore. According to Harder "the ore occurs (a) as an infiltration in and replacement of red and yellow clays along the fault fissure, $(b)$ as a filling in cavities in these clays, and $(c)$ in veins, as cement in breccia, and as replacements in the wall rock."

Mr. W. J. Hammonds showed the writers specimens of manganese ore from a deposit said to be located in sec. 17, T. 5 S., R. 6 E. This locality was not visited, but the specimens closely resemble the better grade of ore obtained at the Ladd mine.

\section{MAGNESITE.}

Magnesite occurs in sec. 35 , T. 17 S., R. 11 E., about a mile west of Sampson Peak, just south of the edge of the area shown on Plate I. This deposit was not seen by the writers, but according to Gale, ${ }^{2}$ who visited the locality in 1912, the magnesite occurs in veins in the serpentine not far from the contact with the overlying sedimentary rocks. The outcrops would seem to indicate a deposit of considerable size.

Fragments of magnesite occur in the Big Blue member of the Vaqueros formation (lower Miocene) along the edge of the San Joaquin Valley. The fragments are scattered over the surface at intervals of a few hundred feet and are entirely insufficient in amount to be of any commercial importance. They are, however, of interest in showing that magnesite was formed in the serpentine in early Miocene or pre-Miocene time.

\section{CHROMITE.}

Small quantities of chromite occur in the serpentine near New Idria. As is noted by Becker, ${ }^{3}$ a small deposit was prospected in the early days under the belief that it was a silver ore. Like the magnesite, chromite is found in small fragments in the serpentine detrital material that forms the Big Blue member of the Vaqueros formation (lower Miocene) bordering the San Joaquin Valley.

\section{BENITOITE.}

I Benitoite, a recently discovered gem mineral, is obtained at the Gem mine, in sec. 25, T. 18 S., R. 12 E., about 7 miles southeast of New Idria. The benitoite occurs in a small area of metamorphosed Franciscan rocks included in the serpentine that forms the crest of the

\footnotetext{
1 Harder, E. C., Manganese deposits of the United States: U. S. Geol. Survey Bull. 427, pp. 159-162, 1910. 2 Gale, H. S., The production of magnesite in 1911: U. S. Geol. Survey Mineral Resources for 1911, pt. 2, p. 1120, 1912; Late developments of magnesite deposits in California and Nevada: U. S. Geol. Survey Bull. 540, pp. 503-509, 1914.

- B Becker, G. F., U. S. Geol. Survey Mon. 13, p. 294, 1888.
} 
Diablo Range near New Idria. Such inclusions are fairly common in the serpentine mass. 'Benitoite is not, however, known to occur in any of the other inclusions, the deposit at the Gem mine being the sole known occurrence of the mineral. For a description of the character and occurrence of benitoite the reader is referred to the papers by Louderback ${ }^{1}$ and Sterrett. ${ }^{2}$

\section{COAL.}

Coal is found at several places in the zones of shale and clay interbedded with the sandstone of the Tejon formation (upper Eocene), and almost everywhere these shale beds are carbonaceous. The coal is in most places of a poor grade, and is usually inconstant both in extent and in character. Lenses of fairly good coal occur, but they are apt to grade within a short distance into carbonaceous shale or seams of carbonized wood. At Tesla a considerable bed of subbituminous coal was mined for a number of years, beginning over half a century ago. In recent years, however, the mining of coal has ceased, and when the region was visited in 1910 the mines were being operated for clay.

On Salado Creek a bed of impure coal outcrops almost at the base of the Tejon formation. Various desultory attempts have been made to prospect this coal but without much success. The bed is at about the same horizon as that at Tesla.

Coal also occurs in the shaly zones interbedded with the white sandstone in both the upper and lower parts of the Tejon formation at several places in the south end of the region. Beds of it have been opened on a small scale on Arroyo Hondo 2 miles south of Ciervo Mountain, in the hills just north of the west end of The Vallecitos, and at several points along the south side of the east end of The Vallecitos, but in no place has the work proved profitable. The small beds west of Coalinga, on which a considerable amount of money was spent many years ago, before the development of the Coalinga oil field, are of similar character and occur in the same formation. Doubtless other beds, some of which might be of commercial importance when opened, occur along the outcrop of this formation, but owing to the irregular distribution of the material and its deterioration in quality near the surface, the difficulty and expenses of discovering workable bodies 'would probably far outweigh any profit that might be derived.

\section{GYPSUM.}

Gypsum is very plentiful in all the formations above the base of the Moreno, occurring as a cement in fine-grained sandstone; as masses

1 Louderback, G. D., Benitoite, its paragenesis and mode of occurrence, with chemical analysis by Walter C. Blasdale: California Univ. Dept. Geology Bull., vol. 5, pp. 331-380, pls. 27-39, 1910.

2 Sterrett, D. B., Gems and precious stones: U. S. Geol. Survey Mineral Resources for 1909, pt. 2, pp. 742-748, 1911 . 
of platy crystals of selenite, along bedding or joint planes and in small cavities; and as efflorescent deposits of impure gypsum or gypsite. Only the deposits of the last-named type are sufficiently large to be of any economic value at present. Two such deposits have been worked, the larger being that of the Paoli mine, at the mouth of Tumey Gulch, where over a considerable area gypsite has formed for a depth of 3 to 15 feet, the average probably being not much over 3 feet. On the divide between Cantua Creek and Arroyo Hondo is a small deposit of gypsite in the upper part of the Kreyenhagen shale from which a small amount has been taken. The gypsum in this region is discussed in a paper by Hess. ${ }^{1}$

LIME.

Beds of impure limestone, marl, and calcareous clay are interstratified with the coarse detrital beds of the Tulare (?) formation at the crest of the Panoche Hills and on either side of Little Panoche Creek about 2 miles below the Mercy schoolhouse. They are best developed at the crest of the Panoche Hills, where they form a considerable portion of the upper part of the flat-lying terrace-like deposit. The hard impure limestone occurs in lenticular masses about a foot thick that are bedded with the softer calcareous clay. The clay in places reaches a thickness of 25 or 30 feet. The uppermost bed usually contains somewhat more lime than those immediately underlying it. The lime has probably been concentrated there by water which leached the underlying beds and which upon reaching the surface evaporated, leaving its lime as a cement for the incoherent materials. Partial analyses of two samples from the terrace at the summit of the Panoche Hills, in the N. $\frac{1}{2}$ sec. 30 , T. 14 S., R. 11 $\mathrm{E}$., are given below. Sample 1 is a fair average of the marl, which is here 15 to 20 feet thick; sample 2 is from one of the thin beds of hard limestone intercalated with the clay.

Partial analyses of calcareous beds in the terrace capping the Panoche Hills in sec. 30, T. 14 S., R. $11 E$.

[Analyst, George Steiger.]

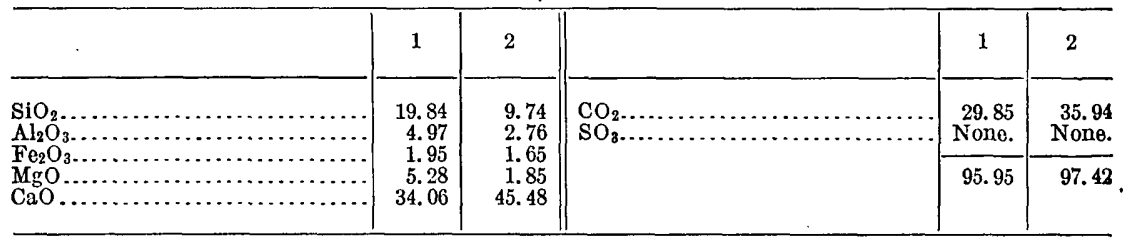

These beds are so intercalated with coarse sand and gravel that it would be difficult to separate the calcareous from the purely detrital material. This fact, combined with the inaccessibility of the beds at the crest of the Panoche Hills, makes them at present of very little economic importance.

1 Hess, F. L., A reconnaissance of the gypsum deposits of California: U. S. Geol. Survey Bull. 413, pp. $9-11,1910$. 
CLAY.

Beds of clay are in many places interstratified with the gray sand of the Tejon formation, especially' in the region north of Pacheco Pass. The clay beds weather more readily than the interstratified sandy beds, and for this reason their character is difficult to ascertain from natural outcrops. The clay is light gray, even in weathered - outcrops, and apparently contains but little iron. Clay of exceptionally good quality occurs in the Tejon formation in the mines at Tesla, overlying the coal for which the mines were originally worked. Little can be told of the character or extent of the bed from the surface outcrops, but it is stated on the basis of the exposures underground that the clay occurs in considerable quantity. The mines were in 1911 being worked only for the clay, which was used in the brick and pottery works at Carnegie and Pottery, a few miles to the east on a branch of the Western Pacific Railway. It is not improbable that other beds of clay of good grade occur in places in the same formation along the foothills between the Tesla region and Garzas Creek, for the character of the Tejon formation throughout this region is similar, so far as is indicated by the surface exposures.

\section{DIATOMACEOUS EARTH.}

Diatomaceous earth forms a large part of the Kreyenhagen shale and occurs also in the Moreno and Vaqueros formations. The material, which is formed almost wholly of the siliceous shells of diatoms, varies from soft, almost earthy though compact and tough, rather massive beds to thinly laminated, slightly brittle beds. It is white and resembles chalk in its general appearance and is commonly called "chalk rock." It is easily distinguished from chalk by the fact that it is not acted upon by ordinary acids. The pure diatomaceous shale is most plentiful in the upper part of the Kreyenhagen shale, in which it forms zones several hundred feet thick that are traceable for miles by their prominent white outcrops. Such material may be found anywhere along the extent of this formation as mapped. It is probably best developed in the hills east of Ciervo Mountain, along the foothills between Little Panoche and Ortigalito creeks, and in the low hills between Orestimba and Little Salado creeks. At the lastnamed locality the shale is somewhat clayey and usually has a faint pinkish tinge on fresh fracture. The beds between Little Panoche and Ortigalito creeks seem to be the purest in the whole region. Diatomaceous earth is also well developed in the upper part of the Moreno formation between Little Panoche and Ortigalito creeks and in various parts of the Vaqueros formation, especially in The Vallecitos. A little of the Kreyenhagen shale from the basal part of the formation has been removed from a small pit about 8 feet deep and 12 feet in diameter located about half a mile northwest of the Crow 
ranch, north of Orestimba Creek. (See Pl. VII, I, $B$, p. 74.) No other attempt has been made to utilize these deposits. It is doubtful whether such material will have any value in this region for a long time to come, owing to the abundant supply obtainable at many more accessible places in the Coast Ranges.

\section{BUILDING STONE.}

Most of the sandstone in this region is not suitable for building stone. Except for that in the Martinez (?) formation south of Panoche Creek the Tertiary sandstone is too poorly consolidated to serve that purpose, and that in the Franciscan so far as seen is either too thin bedded or too much crushed and altered. The massive facies of the sandstone in the Panoche formation and of that in the Cantua sandstone member of the Martinez (?) formation in places afford a good building stone. These sandstones are fine, even grained, and well consolidated. They are gray when fresh, but weather to a pleasing light-brown color. The beds vary from a few inches to several feet in thickness. In many places the sandstone contains hard nodules or concretions which would render it unfit for use in building, but sufficient quantities of massive sandstone free from these concretions occur to furnish a considerable amount of acceptable stone. The stone is of the same age and has the same general physical character as the sandstone quarried in Colusa County, of which several of the larger buildings in San Francisco are constructed. In all probability sandstone equal in quality to the sandstone of Colusa County could - be quarried in certain parts of this region.

The better stone occurs in the southern part of the region. That north of Pacheco Pass is usually less massive and where thick bedded is more commonly concretionary than that to the south. At present the distance to the railroad prohibits the quarrying of building stone here, but should a railroad be built through Panoche Pass the stone near the mouth of Panoche Creek might be quarried profitably.

\section{GRA VEL.}

The flood plains of the larger streams, especially those north of Pacheco Pass, are covered with loose gravel formed largely of flattish pebbles of sandstone from the Franciscan and Panoche formations. This material forms admirable railroad ballast, and a considerable quantity has been excavated in Corral Hollow by the Western Pacific Railway for use both on the branch line running into Tesla and on the main line.

\section{HOT SPRINGS.}

At the Mercy Hot Springs, in Little Panoche Valley, warm mineralized water issues from the base of the terrace deposit where it rests upon fractured greenstones that are associated with the Franciscan sedimentary rocks. The Franciscan rocks are exposed in a 
small area from which the recent terrace gravels that fill Little Panoche Valley have been removed by erosion. So much of the region is masked by the terrace deposits that it is impossible to determine either the true attitude of the rocks exposed at the hot springs or their relation to the overlying Panoche formation. Nor is it possible to state definitely the sources of the spring water. It is believed, however, that the water finds its way up along a fault zone that either determines or lies close along the Franciscan-Chico contact. It is a noteworthy fact that immediately after the great earthquake of April 18, 1906, the flow of these springs lessened materially and the temperature of the water decreased markedly. Later both the flow and the temperature gradually increased, but the normal conditions were not reached for several weeks. The information on this point was obtained from Mr. J. J. Mercy, who has long been familiar with the spring and who observed the peculiar effects exerted upon it by the earthquake, which was strongly felt here. Between 1903 and 1906 the water was bottled and sold as the "Mercey water," but at present it is used only at the springs, where a few bath houses have been erected.

The following is an analysis of the water from the Mercy Hot Springs. This analysis was published in somewhat different form by the Mercey Mineral Springs Co., San Francisco. The analysis in its present form is taken from a paper by Waring. ${ }^{1}$

Analysis of water from main spring, Mercy Hot Springs, Fresno County, Cal.

[Analyst, Marvin Curtis. Constituents are in parts per million.]

\begin{tabular}{|c|c|c|}
\hline \multirow[t]{2}{*}{ 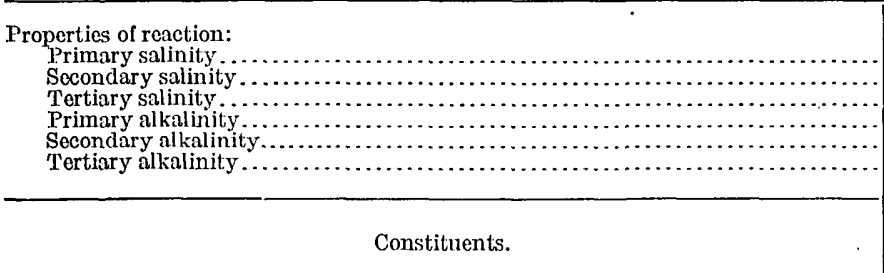 } & \multicolumn{2}{|r|}{$\begin{array}{r}94 \\
3 \\
0 \\
0 \\
3 \\
6\end{array}$} \\
\hline & $\underset{\text { Beight. }}{\text { By }}$ & $\begin{array}{l}\text { Reacting } \\
\text { values. }\end{array}$ \\
\hline \multirow[t]{2}{*}{ 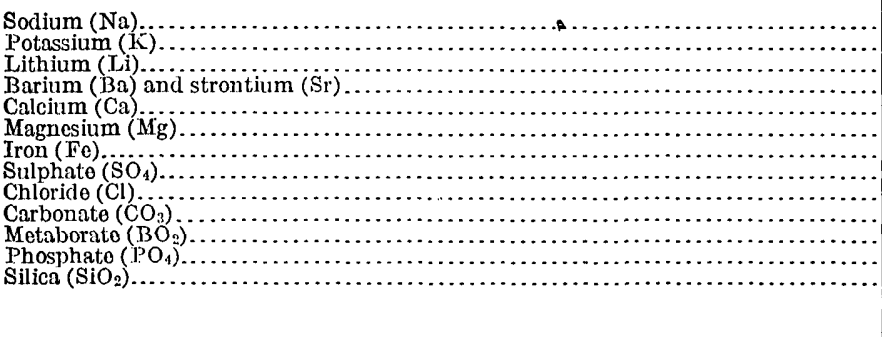 } & $\begin{array}{l}808 \\
5.9 \\
\text { Trace. } \\
\text { Trace. } \\
40 \\
4.5 \\
\text { Trace. } \\
12 \\
1,278 \\
36 \\
2.0 \\
70^{\circ}\end{array}$ & $\begin{array}{r}35.12 \\
.15 \\
\text { Trace. } \\
\text { Trace. } \\
1.98 \\
.37 \\
\text { Trace. } \\
.25 \\
36.03 \\
1.19 \\
.05 \\
.15 \\
2.32\end{array}$ \\
\hline & $2,256.8$ & \\
\hline
\end{tabular}

This water is essentially a solution of common salt with minor impurities. Bubbles of gas rise in the spring and the water there has a faint sulphureted odor, but at the baths, 85 yards away, it has lost this odor.

1 Waring, G. A., Springs of California: U. S. Geol. Survey Water-Supply Paper 338, p. 78, 1915. For full explanation of the terms used consult U. S. Geol. Survey Bull. 479, 1911. 


\section{WATER SUPPIY. ${ }^{1}$}

The eastern flank of the Diablo Range is dry and poorly watered. Throughout the region the average annual rainfall is not over 12 inches, and over a considerable part it is less than 9 inches. Practically all of this falls in the winter months. In consequence there are no perennial streams emptying into the San Joaquin Valley, and indeed few in the foothills that flow except during the wet season. In the mountainous portion of the range many of the small streams are fed by springs and flow on the surface throughout the year, but the water sinks beneath the surface long before it reaches the edge of the San Joaquin Valley.

All the surface water and also that obtained in the wells contains a large amount of mineral salts in solution. Many of the springs and wells afford water too highly charged with salts to be fit for drinking. The purest spring water is that which issues from the massive sandstone of the Panoche formation. That coming from the fine-grained diatomaceous and clay shales is almost invariably very highly charged with salts.

Portions of the foothills in the southern part of the region are used for a cattle range throughout the year, sufficient water for the stock being obtained in small springs and in the beds of the larger streams where the water flows on the surface for short distances. Much of the area is, however, so barren of water that it is used only for sheep grazing during the wet season. The small ranches in the Panoche Valley have shallow pumping wells that produce sufficient water for household use and for a few head of stock, but not enough for irrigation. A similar condition prevails north of Pacheco Pass in the foothills and along the western edge of the San Joaquin Valley for several miles out from the hills. Also in small areas of the foothills to the south of the pass pumping wells are obtained at relatively shallow depths; but in the south end of the region there are only a few wells, and many of the ranchers haul all their drinking water from springs located in the higher hills. In the central part of the San Joaquin Valley, east of the region shown on the map, a constantly increasing area is being irrigated, the water being obtained from San Joaquin River. For a short distance west of the irrigated district the west side of the valley is underlain by artesian water. At present this water is not used, but the time will probably come when it can be obtained economically and the fertile lands in that region thereby be reclaimed.

The late spring flow of a few of the larger streams from the Diablo Range, notably Panoche and Cantua creeks, is utilized in irrigating a few acres close to the foothills, but the total amount of land so watered on the west side of the valley is insignificant. In portions

\footnotetext{
1 For a more detailed account of the ground water of the San Joaquin Valley see Mendenhall, W. C., U. S. Geol. Survey Water-Supply Paper 222, 1908.
} 
of the region it will probably be found possible to impound the flood waters of the larger streams in reservoirs near the edge of the foothills and to irrigate small tracts of the valley adjacent to the hills. In the fall of 1910 a small reservoir was being constructed on the Howard ranch, near the mouth of Quinto Creek, and a site for a larger one had been surveyed farther up the same creek. Puerto Creek would seem to offer a very favorable location for such a reservoir were it shown that that creek would afford sufficient flood water in the wet season. The Tertiary beds at the outer edge of the hills rise sharply from the San Joaquin Valley, determining a marginal ridge through which Puerto Creek has cut a short, steep canyon. Between this ridge and the main range there is an area of low relief carved in a belt of soft shale. With relatively little expense a dam could be constructed across the mouth of Puerto Creek, which would form of this low area a reservoir of considerable size.

About half a mile south of the Mercy schoolhouse Little Panoche Creek is fed by a number of springs, which afford a considerable flow, so that even during the later part of the dry season water is found in the lower course of the creek almost if not quite to the edge of the San Joaquin Valley. The water issues from the lower beds of the heavy terrace deposit which rests upon the more impervious shale and sandstone of the Panoche formation. According to Mr. J. Norrish, an attempt was made several years ago to impound this water by a dam built across Little Panoche Creek opposite the Mercy schoolhouse. The work was, however, stopped before it had been well started, litigation with various landowners lower on the creek being given as the reason for its abandonment. 'If conserved, this water would irrigate a small tract lower on the creek.

In The Vallecitos numerous wells have been dug to depths of 20 to 50 feet. These wells now afford a supply of water for household use and for the range stock. Many of them lie close to the course of the dry stream that passes through the central part of The Vallecitos and derive their water from the base of the shallow alluvial filling of the valley. Other wells have been dug away from the center of the valley in the clays and sands of the Jacalitos and Etchegoin formations, but most of them have proved failures, although a few have tapped local water-bearing sands from which they derive a small supply. The water in some of the wells is fairly free from mineral salts, whereas that obtained in others, even in the wells drilled in the alluvium, is very highly charged with salts. It does not appear likely that any very large quantity of water will be obtained from wells of either of these types. The alluvial filling is very shallow and is limited to the central part of the valley, whereas the Jacalitos and Etchegoin formations are largely clay and relatively impervious, coarse-grained sand and gravel which might act as a reservoir for water forming only a minor part of these formations. 



\section{INDEX.}

A.

Page.

Acknowledgments for aid . . ............... 13-14

Alisal Oil Co.'s well, description and log of.. 189-190 analysis of oil from. 191

Alluvium, distribution and character of .... 105-106 Altamont anticline, possibility of petroleum on or near. 191-192

Anderson, F. M., cited.

Antelope Valley, possible occurrence of petroleum in

Arnold, Ralph, investigations by

Arroyo Cicrvo, location of.

$\Lambda$ rroyo Hondo, location of.

Ashurst Oil Co.'s wells, location of

\section{B.}

Benitoite, occurrence of..

Big Blue Hills, location of.

Big Blue serpentinous member of the Vaqueros formation, distribution and character of.................. 83-84

plate showing huge serpentine bowlders in .............................

plate showing outcrop of............... 83

position of......................... 34,81,82

Big Shell well, description of.............. 164

Building stone, occurrence of............. 212

C.

Calistoga well, location of.............. 170-171

Campboll, M. R., acknowledgment to....... 12

Cantua Creck, location of................. 17 Cantua Oil Co.'s well, description and log of. 166-167 Cantua region, quartzose sandstone cliffs in, ' plate showing................. 68

Cantua sandstone member, character of ...... 59 distribution of....................... 61-62 position of............................ . 33

Carnegie, possibility of petroleum north of.... 193 Cedar Flat, location of................... 17

Cerro Bonito quicksilver mine, description of. $\quad 207$

Cerro Bonito Ridge, location of............. 17

Chico group, description of ............. 26-29,33 distribution and character of . ........... $36-49$

Chromite, occurrence of .................. 208

Ciervo anticline, description of............ $\quad 111$ evidences of petroleum in............... 125 Kreyenhagen and Vaqueros beds in, plate showing................. 82 possibility of petroleum in ............. 178-181

Ciervo Hills, location of ................. 17 unconformity along east face of, plate showing...................... 75

Ciervo Mountain, location of............... 17

Clay, occurrence of ....................... 211

Climate of the region ................... 24-25
Page.

.................. 209

Coalinga anticline, description of.......... $\quad 110$ Coalinga anticlino ficld. See Eastside field.

Coalinga district, occurrence of petroleum in.. 197 Coalinga Royal Oil Co.'s well No. 2, description and $\log$ of.................. 141

Coalinga syncline, description of ........... 110 Coalinga syncline ficld. See Westsido field.

Corral Hollow, possibility of petroleum south of .................... 182-186

Corral Hollow Creck, location of........... 17

Correlation by preceding writers ..... $35-36,49-50,76$

Cottrell, Dr., acknowledgment to......... 124

Cretaceous strata, hills formed by, plato showing..................... 24,60

Cretacoous system, divisions of ............ 36-57

Crow Creek, location of .................. 17

D.

Day, D. T., acknowledgment to............ 13 cited.......................... 131, 142, 190

De Mexico quicksilver mine, description of.. $\quad 207$

Diablo Range, columnar sections of rocks in.. 26-29 correlation of sections in, plate showing. . $\quad 36$ description of...................... 21-22, 24 origin of oil in ..................... 199-203

structure of......................... 108-110

Diatomaceous earth, occurrence of........ 211-212

Diatoms, regarded as the source of petroleum................ 11,48, 198-199

Dikes, sandstone, in the Kreyenhagen shale. $\quad 75$ sandstone, in the Moreno formation..... 46 possible relation of, to petroleum.... 133

Doane well, description of ............. 189, 191 Domengine Creek, exposure of Kreyenkagen shale on, plate showing......... 74

location of.......................... 17

Drainage of the region.................... 24-25

ז.

Eastside or Coalinga anticline field, distribution of deep sand in.......... 151-152

limits of.......................... 148-151

occurrence of petroleum in............ 139-148

Eldridge, George H., investigations by ...... 12

Eocene series, formations of................ 58-74

relation of, to petroleum............... 73-74

Etchegoin formation, distribution and character of $\ldots \ldots \ldots \ldots \ldots \ldots \ldots \ldots . . .64-96$

position of.......................... 34

relation of, to petroleum............... 96

F.

Faults, occurrence of. .................. 114-116

Field work, record of $. . \ldots \ldots \ldots \ldots \ldots \ldots \ldots . .9$

15-3 Oil Co.'s well, description of........... 189 
Foothills of the San Diablo Range, description of.

Foraminifers regarded as the source of petroleum.................. 11, 198-199

Fossils, occurrence of, in the Chico formation. ....................... 37-38 occurrence of, in the Moreno formation................. 46-47,51-52 in the Martinez (?) formation. . 60-61,66-67 in the Tejon formation. . ....... 70,71,72 in the Vaqueros formation. . ........ 85,86

Franciscan formation, character of........ 26-31 Fresno-San Benito well, location of......... 166

$$
\text { G. }
$$

Garzas Creek, location of.

Geography of the area.

................. 17

Gester G. C. cited.......

Gravel, occurrence of................... 212

Griswold Canyon, location of.............. 18

oil seep in the Martinez (?) formation in. . 128

Griswold Hills, location of............... 18

west end of, plate showing............. 60

Gypsum, occurrence of................. 209-210

ت.

Hamilton Ranch, occurrence of petroleum on........................ 187-191

Hammonds Fill, location of............. 18

Hospital Creek, location of................ 18

structure north of . . ............... 113-114

Fot springs, occurrence of............. 212-213

\section{I.}

Ickes, Eugene L., work of. ............... 9,13 Igneous rocks, distribution and character of . ...................... 106-108

Imperial Oil Co.'s well No. 1, description of. 150-151

$\log$ of............................. 151 Independence Oil Co.'s well, description of . . 189 Indian Valley, location of............... 18 Intraformational conglomerate.........44,53

\section{J.}

Jacalitos formation, distribution and character of ...................... 94-96

position of. ....................... 34

possibility of petroleum in. ....... 96,147-148 Jenkins, Olaf, work of. ................. 13

Joaquin Ridge, location of................ 18

Joaquin Rocks, location of............... 18

plate showing....................... 40

John Kern Oil Co.'s well, location of........ 182

Johnson, H. R., work of................ 12

K.

Kern River field, occurrence of petroleum in. 197

Knowlton, F. H., acknowledgment to...... 13

Kreyenhagen shale, character of......... 74-75 correlation of . ...................... 76-77

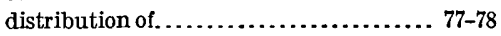
evidences of petroleum in........... 130-133 low-dipping beds of, plate showing..... 82 position of . ....................... 34,35 relation of, to petroleum.......... 78, 146-147 sandstono dikes in, plate showing....... 74 stratigraphic relations of. ............ 75-76
Kreyenhagen shale, typical exposure of, plate showing.................... unconformity of Vaqueros formation with, plate showing............ uses of term

\section{L.}

Laguna Seca Creek, location of. ........... 18

Lands withdrawn from entry, list of. . . . . . . . 204-205

Larious Creek, location of................. 18

Lime, occurrence of....................... 210

Little Panoche Creek, location of........... 18

Little Panoche Valley, terrace deposits in, plate showing................ 104

Livermore Pass, structure near.......... 113-114

Location of the area................... 9,14-15

Los Banos Creek, location of.............. 18

Los Banos fold, description of............ 114

M.

McCreary, R. H., acknowledgment to....... 167

Magnesite, occurrence of................. 208

Mancillas Canyon, evidences of petroleum in. $\quad 123$

Manganese, occurrence of................. 208

Map, accuracy of ....................... 10

Martinez Creek, location of . ............... 18

Martinez (?) formation, age of ............ 66-67 distribution and character of . ........... 58-64 evidences of petroleum in..... 127-129,141-145 position of. ......................... 33 stratigraphic relations of. ............ 64-66

Mendenhall, G., acknowledgment to........ 190

Mercy Hot Springs, description of. ....... 212 213

Mercy quicksilver mine, description of....... 207

Merriam, J. C., acknowledgment to......... 13

Miocene series, divisions of . .............. 78-79 middle. See Santa Margarita (?) formation.

- undifferentiated deposits of............. 88-91

upper, formations of, distribution and character of................... 94-101

Monocline, definition of term ........... 109

Monocline Ridge, location of.............. 19 Monterey group, distribution and character of $80-87$ Moreno formation, distribution and character of..................... 46-49,51-56 evidences of petroleum in......... 57, 122-127 in the Eastside field... . . . . . . . . . 140-141 position of...................... 33,34-35 previous correlation of. . . . ........... 49-50 sandstone dikes in, plate showing....... $\quad 46$ terrace gravels and sands resting on, plate showing................... 105

Moreno Gulch, location of.............. 19

N.

New Bedford Oil Co.'s well, description of... 19,

New Idria, foothills near, occurrence of petro-

leum in.................... 165-167

quicksilver mines at................. 206-207

O.

Oil. See Petroleum

Oil City, evidences of petroleum near.. 122, 127-128 Sce also Eastside field.

Oligocene series. Sce Kreyenhagen shale.

Orestimba Creek, location of............... 19

Ortigalito Creek, location of............... 19 
Page.

Panoche Creek, location of. possibility of petroleum near mouth of. 181-182

Panoche formation, concretionary sandstone of, plate showing.............. 105 distribution and character of............. 39-45 outcrops of, north of Panoche pass, plate showing...................... 40 position of............................ 33, 34

Panoche Hills, location of.................. 19 possibility of petroleum in............. 183 sandstone dikes in, plate showing....... 46 structure in........................... .112 terrace deposits on, plate showing...... 104

Panoche Valley, possibility of petroleum in.. 183 structure in......................... 112

Peerless Consolidated well, description of.... 164 Petroleum, absence of, from Franciscan rocks. $\quad 31$ absence of, from the Panoche formation.. 45-46

in monocline north of Coalinga, reasons for.

accumulation of, controlled by structure........................ 117-121

effect of water upon.......... 117,119-120 analyses of .............. 124,131-133,142,190 areas that may yield............... 11,137-138 factors influencing accumulation of. 11,116-121 formations containing................ 122-137 origin of, in this region............11,194-203

in Moreno and Kreyenhagen shale.. 201 relation of Eocene series to.............. 73-74 relation of Etchegoin formation to...... 96 relation of Jacalitos formation to........ 96 relation of Kreyenhagen shale to.... 78, 130-133 relation of Martinez (?) formation to.. 127-129 relation of Miocene series to............. 79-80 relation of Moreno formation to..... 57, 122-127 relation of Panoche formation to......... 45-46 relation of Pliocene series to............ 79-80 relation of post-Vaqueros formations to. 135-137 relation of San Pablo formation to...... 101 relation of Santa Margarita (?) formation

to ............................ 93-94

relation of Tejon formation to......... 129-130

relation of Tulare (?) formation to...... 105 relation of Vaqueros formation to... 87, 133-135

Petroleum fields of California, relation of oil to shales of organic origin in... 196-198

reports on ........................... 12

Phoenix oil wells, description of... 132-133,146-147

Pimental, The, evidences of petroleum in.... 125 location of.

Pimental Creek, location of

Place names, application of................. 16-21

Pleasant Valley, possibility of deep sands under......................... 156-162

Pleistocene deposits. See Tulare (?) formation.

Pliocene formations, distribution and character of .................. 78-79,94-105

Puente Hills fields, occurrence of petroleum

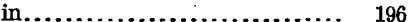

Puerto Creek, location of.

\section{Q.}

Quaternary system, deposits of 105-106 Quicksilver, occurrence of............... 206-207 Quinto Creek.
$\mathrm{R}$. Page.

Ragged Valley, location of................. 20

Range 16 Oil Co.'s well, description of..... 176-177

Rebecca well, character of oil in .......... 124

Rocks, Franciscan, character of............. 26-31 post-Franciscan, character of............ 31-36

Romero Creek, location of ................ 20

S.

Salado Creek, location of................... $\quad 20$ possibility of petroleum near........... 184-185

structure near....................... 113

Salt Creek, location of ..................... 20

Sampson Peak, location of................. 20

San Benito Mountain, location of........... $\quad 20$

San Carlos Bolsa, location of................. 20

San Carlos Creek, location of............... $\quad 20$

oil-bearing shale on.................... 130

San Carlos well, description of............ $\quad 170$

San Joaquin Valley, geologic map of part

of ...................... In pocket.

topography of ...................... 22-23

San Luis Creek, location of ................ 20

San Pablo formation, distribution and character of.................... 96-100

position of .......................... 35

relation of, to petroleum............... 101

Sandstone, bluish, cause of color in......... 82

bluish, occurrences of................ 32,82

concretionary, of the Panoche formation, plate showing................. 105

Santa Clara River fields, occurrence of petroleum in ........................ 169

Santa Margarita (?) formation, distribution and character of .............. 91-93

position of........................... 34

relation of, to petroleum........ 93-94, 147-148 Santa Maria field, occurrence of petroleum in. 196 Schwennesen, Alvin T., work of......... 9,13 Silver Creek, location of .................. 20 Snelling well, character of petroleum from.. 131-132 description of................... 170 Southern area of the region, formations in. . . 33-34 Stalder, Walter, cited.................. 124 Standard Oil Co.'s well No. 80, character of oil in.......................... 142

description of................ 128-129, 142-144

$\log$ of............................. 143 Stanton, T. W., acknowledgment to........ 13 Starke, E. A., acknowledgment to......... 143 Structure of the region................. 108-116 Summerland field, occurrence of petroleum in.......................... 196 Sussex Oil Co.'s well, location of............ 174 T.

Tavern Oil Co.'s well, description of

Tejon formation, distribution and character of.......................6 67,69-73 Tejon formation, evidences of petroleum in.. 129$130,141-145$ position of....................... 33-34,35 stratigraphic relations of.............. 67-69 vegetable matter of, insufficient as source of petroleum............... 202-203

white sandstone cliffs of ............... 68 Temblor Range field, occurrence of petroleum in ........................ 196-197 
Terrace deposits, distribution and character of.

in Little Panoche Valley, plate showing. 104

on the Panoche Hills, plate showing..... 104

Terrace gravels and sands resting on Moreno shale, plate showing

Tertiary strata, hills formed by, plate showing......................... 24,60

Tertiary system, divisions of............. 58-105

Tesla, occurrence of petroleum near....... 136-137, 186-194

Tesla quadrangle, geologic map of part of.... 186

Tracy Oil Co.'s well, description of.......... 191

Tulare (?) formation, distribution and character of................... 102-105

position of.......................... 34,35

relation of, to petroleum............... 105

stratigraphic relations of.............. 101-102

terrace deposits of, plate showing

Tumey Gulch, foothills south of, occurrence of petroleum in............... 162-165

location of........................... 20

Tumey Hills, location of.................. 21

U.

Union Oil Co.'s wells, location of.
V.

Page.

Vallecitos, The, evidences of petroleum north of ........................ 123-125 evidences of petroleum south of....... 128,135 location of......................... 21 occurrence of petroleum in.... 120-121,167-178 Vallecitos Development Co.'s well, description of.................... 176-177

Vallecitos syncline, description of........... 111

Vaqueros formation, distribution and character of..................... 80-87 evidences of petroleum in..... 133-135, 145-146 low-dipping beds of, plate showing..... 82 position of.......................... 34 relation of, to petroleum............... 87

Vaqueros formation, stratigraphic relations of ....................... 80-81 unconformity of, on Kreyenhagen shale, plate showing................. 75

Vegetation of the region.................. 25 W.

Ward, Shirley C., acknowledgment to....... 167 Water supply of the region.............. 214-215 Westside or Caalinga syncline field, occurrence of petroleum in......... 153-156 possibility of deep sands under........ 156-162 Williams, Bert, acknowledgment, to........ 141 W. M. \& S. Co.'s well, description of..... 189, 191 